

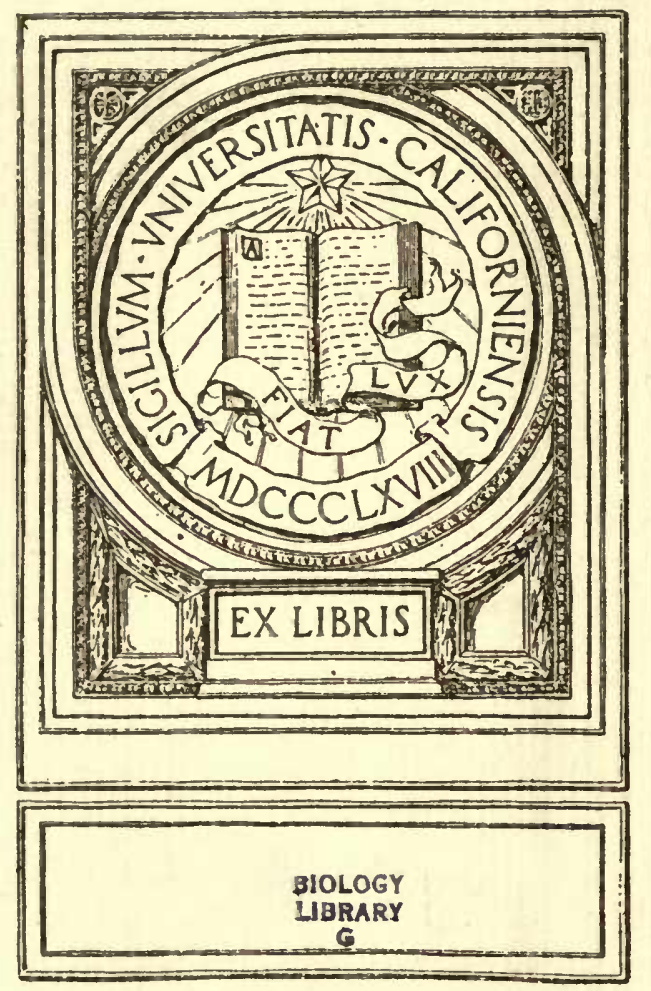



NOTES.

ON THE

\section{BIRDS OF NORTHAMPTONSHIRE \\ AND NEIGHBOURHOOD.}





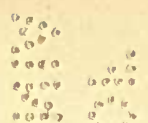

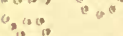

0

(10)

13

00600000

¿coos

$\because \because 0$ opout

$\therefore$ "was

$\therefore 0^{\circ}$ 


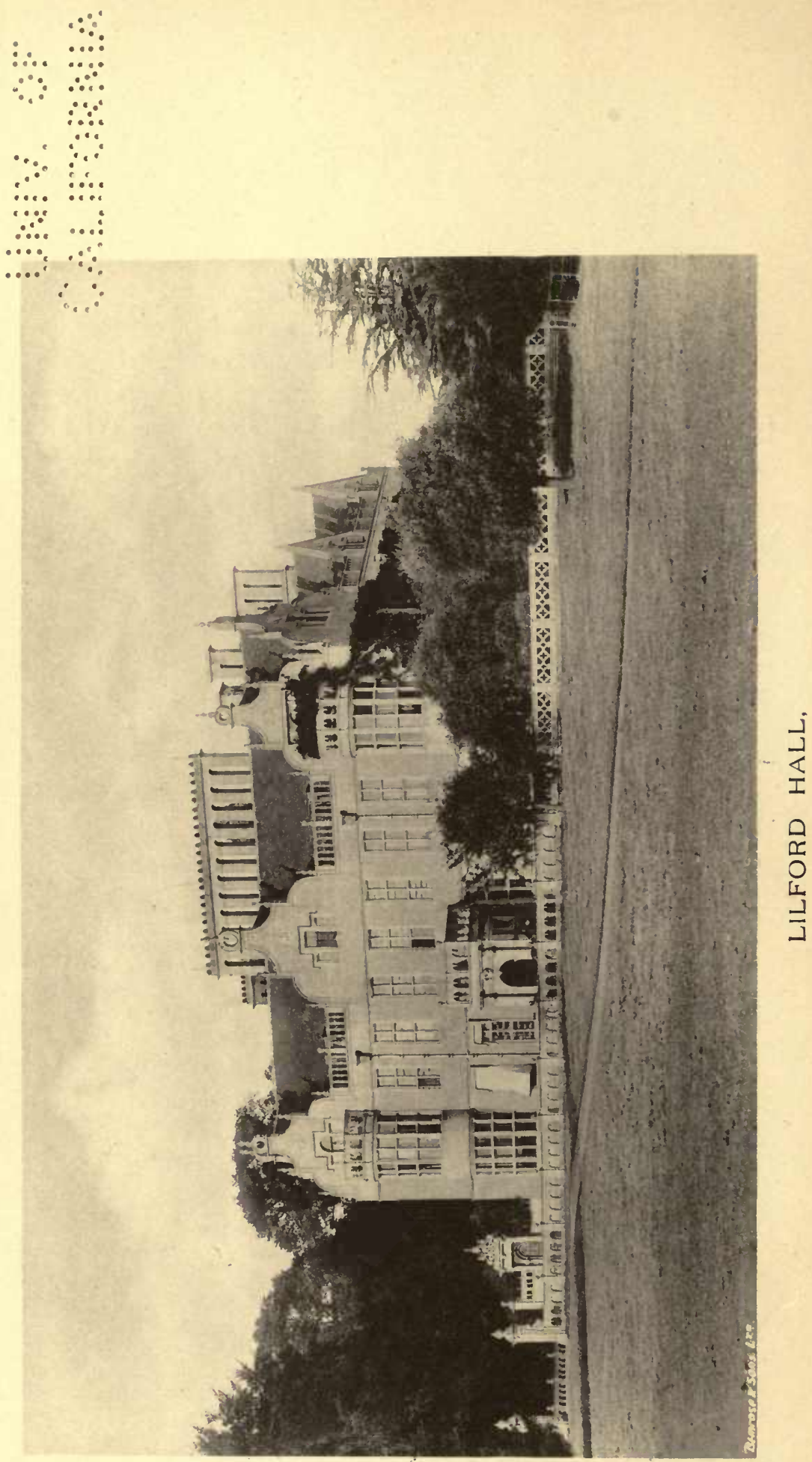




\title{
NOTE S
}

\author{
ON THE
}

\section{BIRDS OF NORTHAMPTONSHIRE AND NEIGHBOURHOOD.}

\author{
$\mathbf{B Y}$ \\ LORD LILFORD, \\ PRFSIDENT OF THE BRITISH ORNITHOLOGISTS' UNION AND OF \\ THE NORTHAMPTONSHIRE NATURAL HISTORY SOCIETY.
}

VOL. I.

ILLUSTRATED

BY

MESSRS. A. THORBURN AND G. E. LODGE.

AND A MAP.

\section{LONDON :}

R. H. PORTER, 18 PRINCES STREET, CAVENDISH SQUARE, W. 1895. 

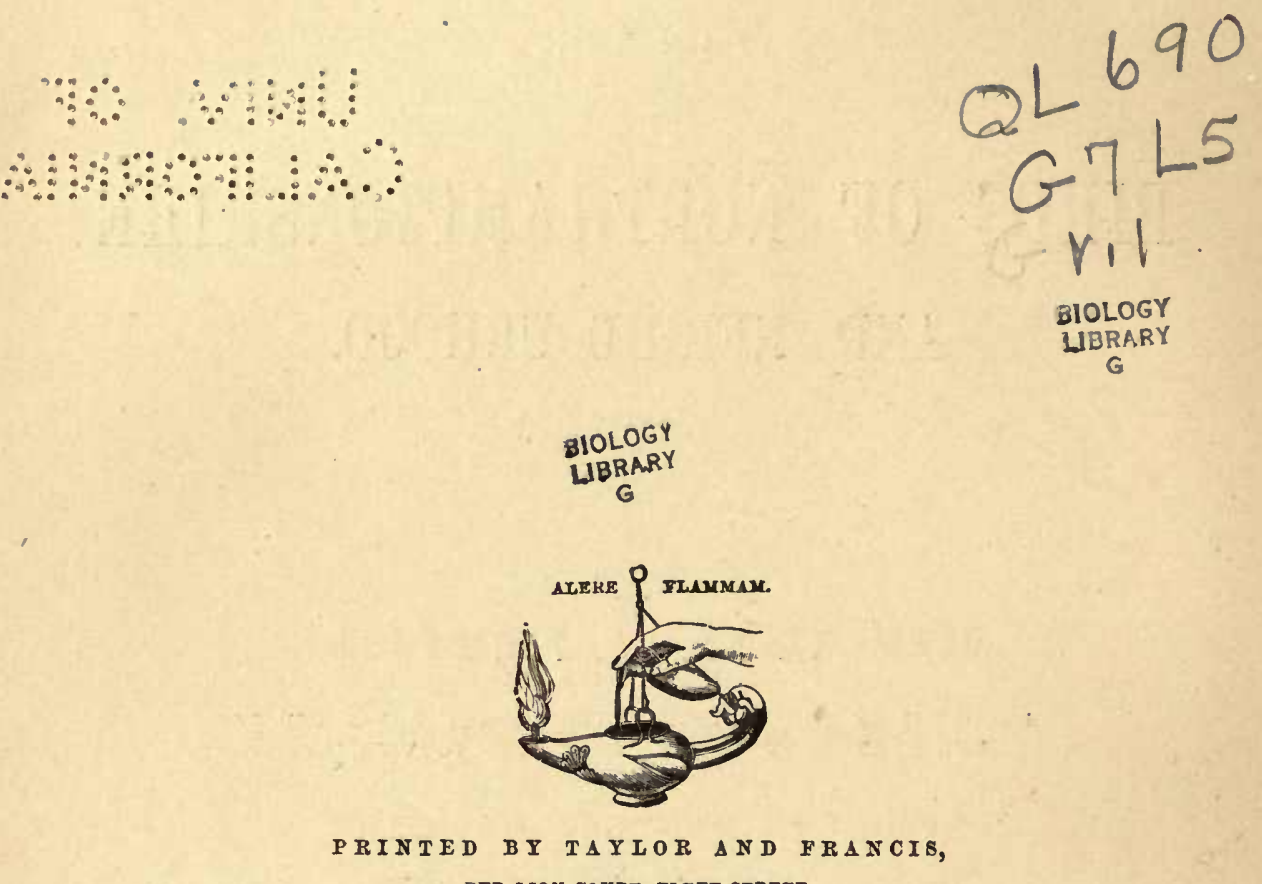
RED LION COURT, FLEET STREET. 
CLEMENTINA, LADY LILFORD,

THESE NOTES ARE DEDICATED

WITH THE DEEPEST DEVOTION

OF

HER HUSBAND. 



\section{PREF A CE.}

THE bulk of the following Notes has already been published at irregular intervals in the 'Journal of the Northamptonshire Natural History Society' from its commencement in 1880 up to the end of 1893 . I must explain my frequent reference to various parts of the world by stating that in the early years of our Society's existence we had not any member but myself who had devoted any special attention to ornithology, and I therefore thought it well to tell all that I knew from personal experience with regard to the birds of which I had to treat. With reference to the scope of these observations, I soon found it extremely irksome to confine them strictly to the political boundaries of our county, and have therefore occasionally overstepped these arbitrary limits into the bordering counties of Huntingdon, Bedford, and Cambridge, doing my best not to trespass into Oxfordshire, Leicestershire, Rutland, or Lincolnshire, whose ornithology has been dealt with by other authors. Our 
county is so easy of access, and has been so well described and illustrated in all its aspects, except that of ornithology, that I consider it as quite superfluous to attempt any description of its geology and other natural conditions. I have no pretence to the title of scientific ornithologist, but I have been a lover of birds since my earliest years, and a close observer of their habits, till debarred from such observation by physical infirmity.

LILFORD.

November 1895. 


\section{CONTENTS OF VOLUME I.}

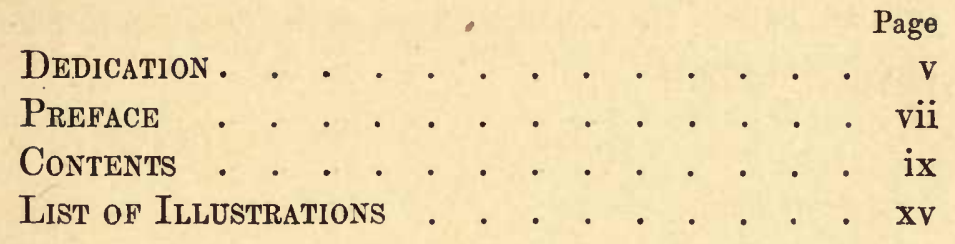

1. Golden Eagle . . . . . . . . . 3

2. White-tailed Eagle. Sea-Eagle . . . 5

3. OSPREY . . . . . . . . . . . . 7

4. Peregrine Falcon . . . . . . . . 10

5. Новву . . . . . . . . . . . . . 14

6. MERLIN . . . . . . . . . . . . 19

7. Kestrel . . . . . . . . . . . . 23

8. Sparrow-Hawk . . . . . . . . 26

9. Kite . . . . . . . . . . . 30

10. Common Buzzard . . . . . . . . . 35

11. Rough-legged Buzzard . . . . . . 39

12. Honey-Buzzard . . . . . . . . 41

13. Marsh-Harrier . . . . . . . . . 44

14. Hen-Harrier . . . . . . . . . . 46

15. Montagu's Harrier . . . . . . . 48

16. TaWNY OWL . . . . . . . . . . . 49

17. LONG-Eared OWL . . . . . . . . 51

18. Short-Eared OWL . . . . . . . . 54

19. Scops OWL . . . . . . . . 57 
20. BARN OWL . . . . . . . . . 60

21. Litthe OWL . . . . . . . . . . . . 66

22. Great Grey Sirike . . . . . . . . 69

23. RED-B.ICKED SHRIKE . . . . . . . . 74

24. WOODCHAT . . . . . . . . . 78

25. Spotted Flycatcher . . . . . . . 80

26. Pied Flycatcher . . . . . . . . . 82

27. Golden ORIOle . . . . . . . 84

28. DipPer . . . . . . . . . . 86

29. Mistletoe-Thrush . . . . . . . 90

30. Song-Thrush . . . . . . . . . . 91

31. RedWING. . . . . . . . . . . 93

32. Fieldfare . . . . . . . . . 95

33. Blackbird . . . . . . . . . . 98

34. RING-OUzeL . . . . . . . . . . . 99

35. Hedge-Sparrow . . . . . . . . . 101

36. Redbreast ... . . . . . . . . . 103

37. Nightingale . . . . . . . . . 105

38. Redstakt . . . . . . . . . . . 107

39. Black Redstart . . . . . . . . 108

40. Stonechat . . . . . . . . . . 110

41. Whinchat . . . . . . . . . 112

42. Wheatear . . . . . . . . . 114

43. Great Reed-Warblek? . . . . . . 116

44. REED-WARBLER . . . . . . . . . 118

45. Sedge-W WARbler . . . . . . . . 120

46. GRASShopper WARbler . . . . . . 122

47. Whitethroat . . . . . . . . . 124

48. Lesser Whitethroat . . . . . . . 125

49. GardeN-W

50. BLACKCAP . . . . . . . . . 129

51. WOOD-WREN . . . . . . . . 130

52. WILlow-WREN: . . . . . . . 131 
5age

53. Chiffehaff . . . . . . . . 133

54. Golden-Crested Wren . . . . . . . 134

55. WREN . . . . . . . . . 136

56. Tree-Creeper . . . . . . . . . 137

57. Nuthatch . . . . . . . . . 138

58. Great Titmolse . . . . . . . . . 141

59. Blue Titmouse . . . . . . . . . . 142

60. Coal Titmouse. . . . . . . . . . 143

61. Marsh-Titmouse . . . . . . . . . 145

62. Long-tailed Titmouse

63. Bearded Titmouse . . . . . . . . 148

64. WAXWING . . . . . . . . 150

65. Pied Wagtail . . . . . . . . 153

66. Grey Wagtall . . . . . . . 157

67. Yellow Wagtail . . . . . . . . 158

68. Tree-Pipit . . . . . . . . . . . 159

69. Meadow-Pipit . . . . . . . . 161

70. Richard's Pipit . . . . . . . . 163

71. SKY-LARK . . . . . . . . . . 163

72. WOOD-LARK . . . . . . . . . 167

73. Snow-Bunting . • • . . . . . 169

74. Reed-Bunting . . . . . . . . . 172

75. Common Bunting . . . . . . . . . 174

76. Yallow Bunting or Yellow Hammer . 175

77. Cirl-Bunting . . . . . . . . . 176

78. Chaffinch . . . . . . . . 178

79. Brambling . . . . . . . . . . . 179

80. Tree-Sparrow . . . . . . . . 181

81. Hotse-Syarrow . . . . . . . . . 183

82. HAWFINCH . . . . . . . . . . 185

83. GReENFINCH . . . . . . . . 189

84. GoldFINCH . . . . . . . . . 191

85. Siskin . . . . . . . . . . . 193 
86. Mealy Redpoll . . • . . . . . 195

87. LeSSER REDPOLL . • . . . . . . . 196

88. LINNET * • . . . . . . . 197

89. Twite . . . . . . . . . 198

90. Bullfinch . • . . . . . . 200

91. Crossbill . . . . . . . . 203

92. Starling . . . . . . . . 207

93. Rose-coloured Pastor . . . . . . . 210

94. RAveN . . . . . . . . . . 211

95. Carrion-Crow . . . . . . . . 216

96. GReY Crow . . . . . . . . 218

97. RoOK . . . . . . . . . 221

98. J JCKDAW • . . • . . . . 226

99. MAGPIE . . . . . . . . . . 229

100. $\mathrm{J}_{\mathrm{AY}}$. . . . . . . . . . . 232

101. Swallow . . . . . . . . . 235

102. Martin . . . . . . . . . . 237

103. SAND-Martin . . . . . . . 238

104. SWIFT . . . . . . . . . 240

105. Nightjar . . . . . . . . . 242

106. Cuckoo . . . . . . . . . . 244

107. HoOpoe . . . . . . . . . . 248

108. Roller . . . . . . . . . . . . 253

109. Conmon Kingfisher . . . . . . . 255

110. BeE-Eater . . . . . . . . . . . 259

111. Green WoodPecker . . . . . . 263

112. Greater Spotted Woodpecker . . . 267

113. Lesser SPOTted WoOdPecker . . . . 270

114. WRXNeck . . . . . . . . . 273

115. Ring-Dove or Wood-Pigeon . . . . . 276

116. Stock-Dove . . . . . . . . . 281

117. Turtle-Dove . . . . . . . . . . 283

118. Pallas's Sand-Grouse . . . . . . 285 
119. Buack Grouse 289

120. RED Grouse . . . . . . . . . 292

121. Pheasant . . . . . . . . . . 292

122. Common or Grey Partridge . . . . . 296

123. Red-legged Partridge. . . . . . . 304

124. Common Quall . . . . . . . . 310

125. LAND-RAIL . . . . . . . . . . 315

126. Spotted CRake . . . . . . . . 320

127. WAtER-RAIL . . . . . . . . . 323

128. Waterhen . . . . . . . . . . 325

129. Purple Gallinule . . . . . . . 328

130. Соот . . . . . . . . . . . 331

131. Great Bustard . . . . . . . . 335

132. Little Bustard . . . . . . . . . . 349 



\section{ILLUSTRATIONS TO VOLUME I.}

Frontimpiece: IIIFORD HAII.

The Photogravure Plates are from drawings by A. THORBURN, and the Wood-Engravings are by G. E. LODGE.

Goldex Eagle . . . . . . . to face $\frac{\text { Page }}{4}$ Sea-Eagle . . . . . . . . . . . . .

OSPREY . . . . . . . . . . . .

Peliegrine and Kestrel . . . . . . . . 13

Hobby AND NeST . . . . . . . . . . 16

Merlin . • . . . . . . . . . . . 22

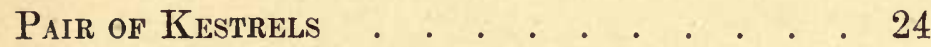

Sparrow-Hawk with Thrusil . . . . . . 29

Soaring Kite . . . . . . . . . . . . 31

Common Buzzard with Mole . . . . . . . 36

Honey-Buzzard at Wasp's Nest . . . to face 42

Marsh-HaRrier . . . . . . . , , 44

Montagu's Harrier . . . . . . . " 48

LoNg-eared OWL MOBBED by 'Tits . . . . . 52

Short-eared Owl with Vole . . . . . . 55

BarN Owls at HoNe . . . . . . . . . 61

INqUisitive Interviewers . . . . . to face 66

Great Grey Shrike . . . . . . . . 72 


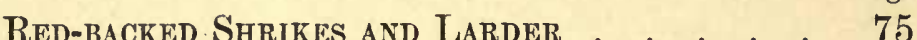
Wоорснат . . . . . . . to face 78 Fieldfares . . . . . . . . . . . . 97 Rivg-Ouzel and Sparrow-Hawk . . to face 100 REED-WARBLERS. . . . . . . . " 118 CoAl-Tits IN DOUbT . . . . . . . . 144 A Long-tailed Family . . . . . to face 146 Distinguished Foreigners . . . . . . . . 151 Pied Wagtall and Brood . . . . . . . 155 Snow-Buntings . . . . . . . . . . . 171 Cirl-Bunting . . . . . . . . . . 177 BRAMblingS . . . . . . . . . . . . 180 Hawfinch .. . . . . . . . . . . . 186 Greenfinches, with Nest and Young . . 190 A Prickly Question . . . . . . . . . 192 Siskins in Winter . . . . . . to face 194 Bullfinches and Nest . . . . . . . . 201

Crossbills on Fir-tree . . . . . . . . 205 ROOK AND JACKDAWS • . . . . . . . . 226 INTERESTED INSPECTION . . . . . . . . 233 Hoopoe . . . . . . . . to face 248 KingFisher . . . . . . . . . . . . 257 Greater Spotted WoodPecker . . . . . 268 Little Woodpeckers at Home . . . to face 270 SAND-Grouse . . . . . . . . . . . 286 Driven Partridges . . . . . . to face 296 SPotted Crake and Water-RaIL . . " 320 Coots at their NFST . . . . . . to face 332 Great Bustard . . . . . . . . . . . 339 


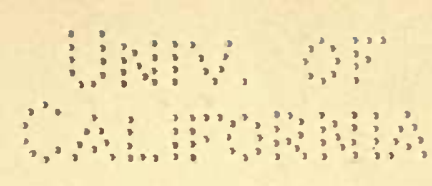

\title{
NOTES
}

ON THE

\section{BiRdS OF NORTHAMPTONSHIRE}

\author{
AND NEIGHBOURHOOD.
}

THE following notes on birds observed by me in this district have no pretension to be a complete account of the avifauna of our own county, but are merely the result of my own observations and those of friends on whose accuracy I could rely. I have for a long time entertained the idea of publishing a work on the ornithology of Northamptonshire, and, having made this idea known, have received many letters containing information more or less valuable from gentlemen, many of them personally unknown to me, residing in or near the county. To all my correspondents I hereby offer my most sincere acknowledgments, and must offer a few words of explanation as to the causes which have hitherto prevented my availing myself of their ready kindness in sending me their observations and remarks. Many of these 
were plain statements of fact, and bore the impress of accuracy, but there were also many more or less vague, and requiring strict investigation and verification, and it is just this investigation and verification, which I have been unable, from ill-health and consequent long absences from home, to carry out as I had hoped in more favourable circumstances to have done. The same causes have prevented the possibility of a methodical series of observations of my own on the arrival and departure of our migratory species, the nesting-habits of such as breed with us, and many other points of interest, and must be my excuse for the many imperfections which will no doubt be discovered in these pages. But if any reader should by them be induced to devote more attention than he has hitherto done to the accurate observation of our birds, and especially to the record of such observations, I shall consider that they have not been written quite in vain.

I have more than once heard it said that British ornithology is worked out, and that there remains no more to be done therein, but this I emphatically deny, and maintain that we have yet much to learn on the subject, and that accurate personal observation is and always will be of infinite value. For a comparatively inland county I think that our list of birds will compare favourably in point of number of species with any other, but recorded observations are lamentably few, and with the exception of the list given in Morton's 'Natural History of Northamptonshire' (1712), and a few scattered notices of birds in the 'Zoologist,' the 'Field,' and the county newspapers, I am not acquainted with anything in print on the subject. I may mention that $I$ was fortunate in having for a 
near neighbour the late Mr. George E. Hunt, of Wadenhoe House, who was a keen and accurate observer, and to him I am indebted for a great deal of information on the birds of our immediate vicinity. I am glad to think that the mania for the indiscriminate slaughter of every so-called rare bird is decidedly on the decrease, and that in many parts of England the taste for ornithological observation is as decidedly on the increase. With the southern division of Northamptonshire I have very little acquaintance, and my observations must be taken as relating (chiefly) to the northern division and the adjacent portion of Huntingdonshire.

\section{GOLDEN EAGLE. \\ Aquila clirysaëtus.}

A very fine specimen of this Eagle was shot by one John Barratt in the High Woods between Burghley House and Walcot, the seat of R. Nevile, Esq., in the month of October 1849, and preserved at the latter named place, where I saw it in 1859. I have no record as to the sex of this bird. The great majority of Eagles recorded as Golden in county newspapers and elsewhere, as occurring from time to time in various parts of England, have, on examination, proved to belong to the other indigenous British species of Eagle, viz. Haliaëtus albicilla, the Whitetailed or Sea-Eagle, and the occurrence of a genuine Golden Eagle so far from its present breeding-haunts 
is therefore an interesting fact. With reference to the Golden Eagle above mentioned, I am informed by G. M. Edmonds, Esq., of Oundle, in a letter dated February 29th, 1876, as follows:- "Riding through Elton Park, as near as I can recollect twenty years since, I saw at 9 o'clock A.M. unmistakably an Eagle flying slowly about 100 yards from me; I told some of my friends here.... A few days after this I saw in the Stamford paper that a Golden Eagle had been shot by Mr. Nevile's keeper at Walcot Park, near Barnack." I have no doubt that this was the same bird, and attach no importance to the discrepancy of dates, as Mr. Edmonds only wrote from recollection. I have received other notices of the occurrence of this species in Northamptonshire, but do not consider them sufficiently definite or supported by evidence to be worthy of particular record.

I am glad to say that the Golden Eagle still breeds in many parts of the Highlands of Scotland, and in several localities is protected by the owners and lessees of deer-forests and grouse-shootings. I had frequent opportunities of observing the habits of this species during my nine years' tenancy of a wild district in Inverness-shire, in which they regularly nested. I never saw them capture or even pursue a bird of any sort, and have the best of reasons for believing that their principal food in Scotland consists of the Blue Hare and Rabbit.

The specimen referred to at the commencement of this article was most obligingly presented to me by Mr. Ralph Nevile in February 1891. It is, in my opinion, in the plumage of the second year. Mr. J. Cullingford, of Durham, to whom I sent this bird for re-mounting, assured me that the flesh had not been 


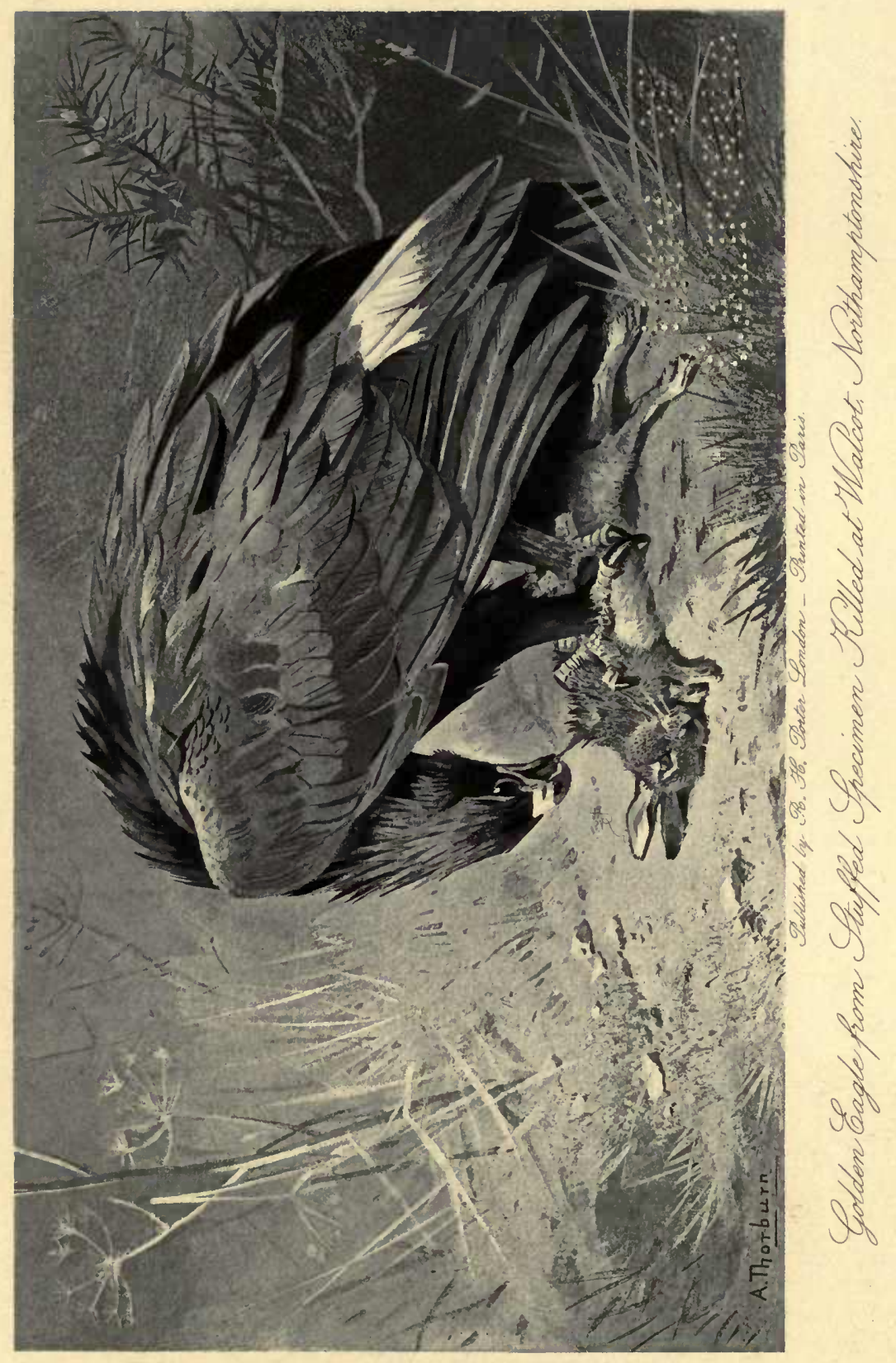




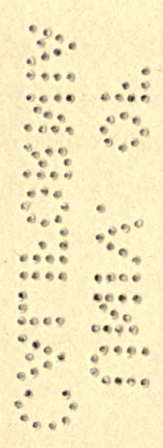


removed from the back, or the wing and thigh-bones. In spite of this neglect, he has made an excellent job of the restoration, and this Eagle has the appearance of a freshly-killed bird.

\section{WHITE-TAILED EAGLE. SEA-EAGLE.}

\section{Haliaëtus albicilla.}

This Eagle, which may almost be classed as a regular winter visitor to the eastern coasts of England, has occurred several times to my knowledge in Northamptonshire in immature plumage. A specimen stuffed at Bulwick Park, Wansford, the seat of Lieut.Col. Tryon, was killed, as the late Thomas Tryon, Esq., assured me, near that place. I have no record as to date, but it is at least forty years since I first saw it there, and it had then been stuffed for some years*. There is another specimen (stuffed) at Burghley House, Stamford, which was shot close to that place many years ago. Another occurrence of this species in Northamptonshire with which I am acquainted was in January 1875, on the 7th of which month a labouring man at work near Spring Wood, Benefield, obseried a large bird flying low and pursued by Rooks. There was a strong wind at the time, and, so far as I can ascertain, the Eagle (as it proved to be), flying down wind, was unable to clear a high thick hedge, and became entangled therein; upon which the man above mentioned ran in, and after a violent struggle succeeded in conquering the bird. The Fitzwilliam Hounds, with many

* This Eagle was very kindly sent to me as a present by Mrs. Tryon, widow of Lieut.-Col. Tryon, in August 1891. 
followers, arrived upon the scene of action at this moment, some gentlemen lent whip-lashes to secure the Eagle, and suggested to its captor that it had probably escaped from my menagerie, and that he had better bring it to me. I was abroad at the time, no bird was missing from my collection, but the person in charge gladly accepted this addition thereunto, set its thigh, which was broken, and when I came home in the following month of August I found the bird in good condition, but subject to occasional fits of vertigo. On inquiry I found that one of my gamekeepers had fired at an Eagle flying over Lilford Wood two days before this bird was caught, and I have no doubt that, besides breaking its thigh, a pellet of shot had lodged somewhere in the head and caused these fits, from which the bird never entirely recovered, and died in 1879.

On February 27, 1891, I heard from Mr. H. Field, of Kettering, that a Sea-Eagle had been shot at Oakley on the $24 \mathrm{th}$, and sent to him for preservation on the 25th. I at once sent a competent person to Kettering, and obtained the following details:The Eagle was shot by a man in the employment of Mr. Northen, tenant of Oakley Lodge, who had noticed it about all the afternoon of $24 \mathrm{th}$. "Owing to the dense fog that prevailed it did not go to any distance, so he sent one of his men across the field gently, as the bird could see him, and this man crept up close to it under the hedge, so shot it through the neck, and broke one wing." Mr. Field informed me that this bird was a female, and measured $3 \mathrm{ft} .4 \mathrm{in}$. in total length, $8 \mathrm{ft}$. in expanse of wings, and weighed about 8 lbs. It was eventually obtained for preservation by Sir R. de Capell Brooke, the owner of the farm 

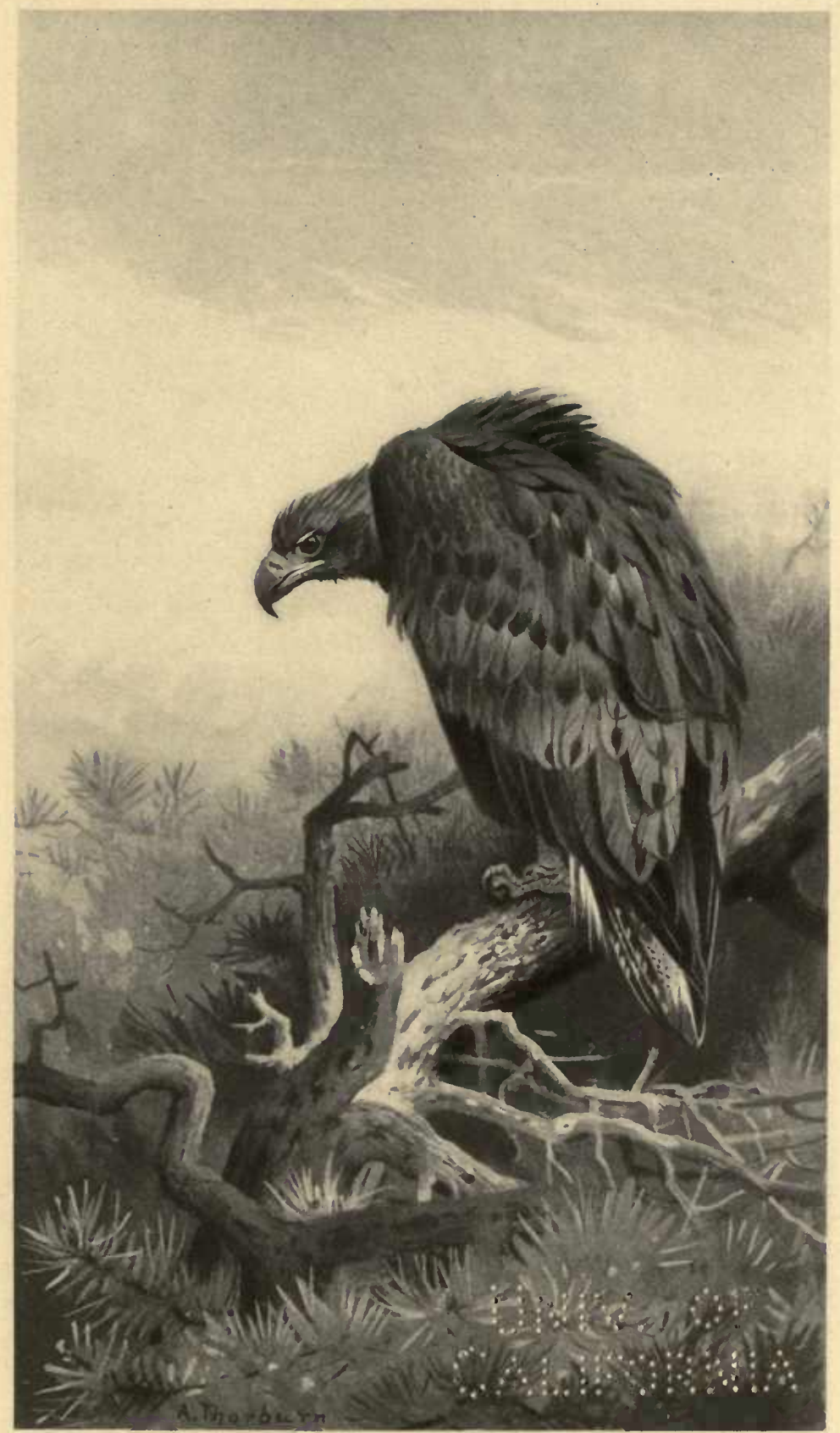

Sublidied try DP IT Sorter.

$$
\text { San bighter }
$$




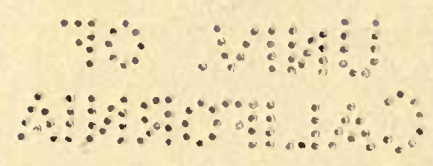


upon which it was butchered (cf. 'Zoologist,' June 1891).

Mr. B. Wentworth Vernon has informed me that he watched two Eagles (in all probability of this species) soaring high in air over his park at Stoke Bruerne near 'Towcester, for nearly two hours, in March or April 1891.

I have received other notices of Sea-Eagles having been shot in and near the borders of our county, but they are all somewhat vague, and some of them without doubt refer to the Osprey (Pandion haliaëtus). The White-tailed Eagle formerly bred in several localities in Scotland and Ireland, in both of which countries I have often met with it. I have a very fine female of this species alive here, which was taken from a nest in the county of Waterford in 1854, and is in perfect health and fine plumage at this time (December 1893). The White-tailed Eagle is a much more indiscriminate feeder than the Golden, and will not reject carrion of any sort.

\section{OSPREY.}

\section{Pandion haliaëtus.}

'This fine species has occurred several times to my knowledge in our county. It is thus alluded to by Morton in his work on the 'Natural History of Northamptonshire' before mentioned:- "The Bald Buzzard, the Sea-Eagle or Osprey of Aldrovandus, which is sometimes taken in traps in and near our Fenland, where it is very mischievous."

A specimen was obtained at Milton, near Peterborough, in 1823. It has been several times met 
with and occasionally shot at Deene Park and at Blatherwycke, where one was killed in 1870 by H. O. de Stafford, Esq. I have an Osprey stuffed that was killed in the Park at Boughton, Kettering, flying over with a perch in its talons, in 1869, and Mr. G. M. Edmonds, before quoted, kindly informs me that he saw and pursued an Osprey about Perry Herne, on the Nen below Oundle, for a whole day in October 1863. I have myself only twice clearly identified the bird alive in these parts, viz. on April 18,1870 , when my attention was attracted by a great uproar among the Rooks, which were busy at their nests in a large rookery at a short distance from this house and near the river. I looked up from my fishing, and saw a large bird flying towards me down the course of the river at no great height; I stepped behind a bush; and the Osprey flew over within easy shot-range, hotly pursued by a number of Rooks, of which he seemed to take very little notice; he circled once or twice over a wide part of the river just below Pilton Bridge, and sailed away in a north-westerly direction, probably bound on a visit to Biggin Pond, near Oundle, where an Osprey was shot some thirty years ago, as I was informed by the late David Watts Russell, Esq.

An Osprey passed within easy gunshot-range of me as I sat fishing from my boat on the river between Iilford and Oundle on August 25, 1883. I first saw the bird coming down the course of the river at some distance above me, flying low, and hotly pursued by a Cröw and many Swallows, and I snatched up my gun, but soon recognizing the species of the stranger, sat still, and the Osprey came on till within forty or fifty yards before noticing us; he then soared away 


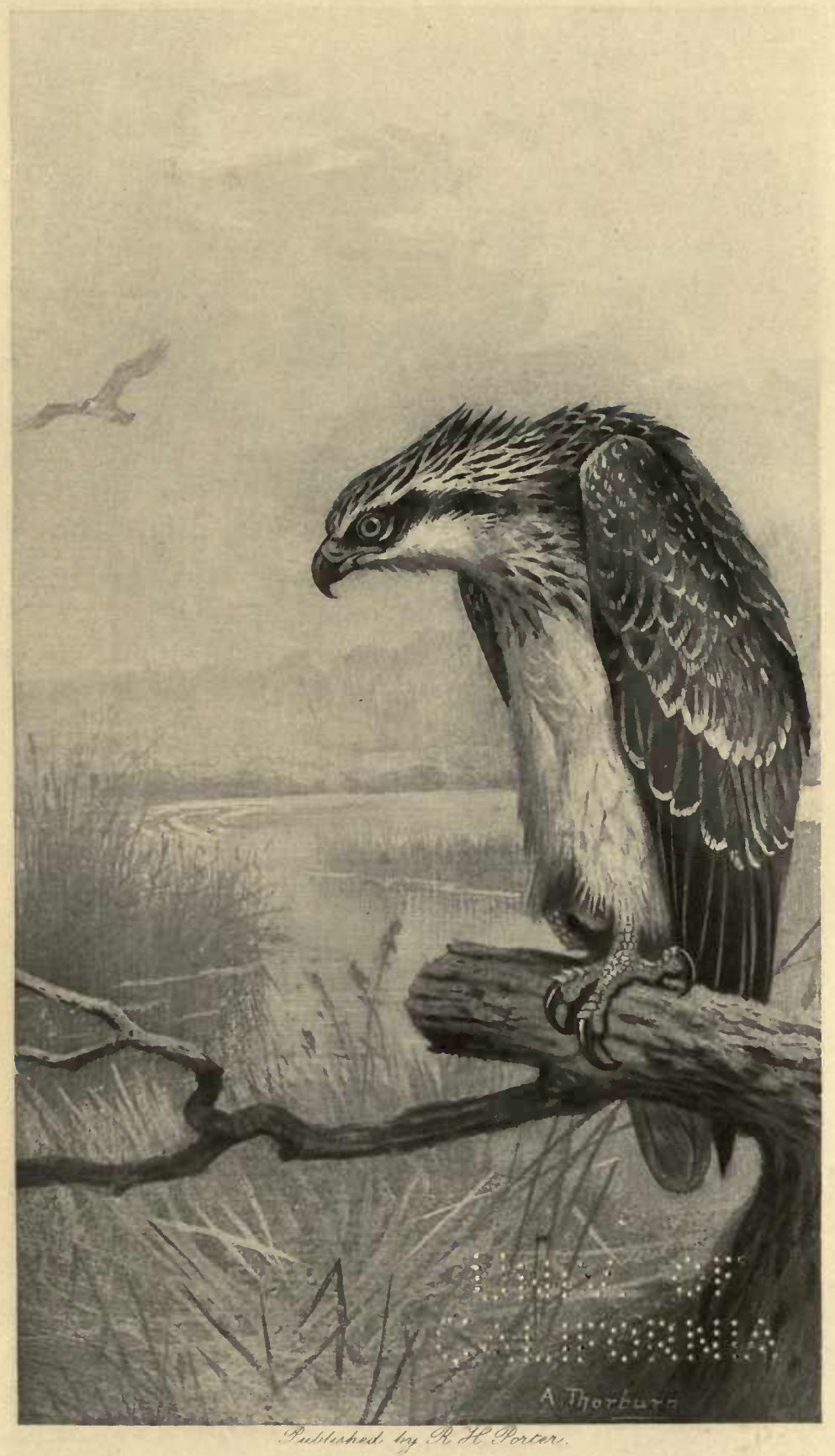

\section{Vopirey}


$\because \because \quad \therefore \quad \therefore \quad \vdots$

$\therefore 040$ 
high in air over the deer-park, pursued by a cloud of Rooks and Hirundines. We had a good view of him on the following day near Aldwincle, and saw him make two unsuccessful stoops into a broad reach of the river. On this occasion some Wood-Pigeons disturbed from a wheat-stubble appeared to take some interest in the proceediugs, and mobbed the Fish-Hawk in a sort of half-hearted fashion for a few minutes. This bird was last seen in the neighbourhood of Lilford on August 29 ( $c f$. 'Zoologist,' 1883). On August 5, 1887, I saw a large raptorial bird soaring at a great height over the meadows near Lilford. I had no glasses, but have very little hesitation in pronouncing this bird to have been an Osprey.

The Osprey was formerly a common summer visitor to the lakes of Scotland, where it still occasionally breeds, and where I have several times met with it. I believe this bird to be exclusively piscivorous, and, though I have never kept a living specimen, am informed that it will not thrive in captivity. even when plentifully supplied with its natural food. I know few more interesting sights than that of an Osprey fishing; the bird circles over the water at a moderate height till it spies a fish which suits its views, when it poises itself for a second or two, and falls like a stone upon its prey, which is carried off to some favourite rock or bough and devoured. Almost all the occurrences of the Osprey recorded of late years in England have been either in the spring or autumn, probably of birds on their way to or from the breeding-localities in the north. 


\section{PEREGRINE FALCON.}

Falco peregrinus.

This Falcon is an irregular, but by no means an uncommon, visitor to this part, at all events, of Northamptonshire; and though the county does not possess any localities suited to its breeding-habits, I consider it, after the Kestrel and Sparrow-Hawk, unquestionably our most common diurnal bird of prey. To record occurrences would be tedious and unnecessary, but I may mention that there are stuffed specimens of the Peregrine in most of the country houses in this division of the county that I have visited, and that, from the middle or end of September till March or April, few days occur when it may not be seen about the valley of the Nen between Thrapston and Oundle. In this locality we have several high old trees, for the most part ash or elms, with dead boughs near the top; these are the favourite look-out stations of the Peregrine, commanding as they do a long and wide range of meadow and arable land, and rendering the unperceived approach of a human enemy almost impossible. I believe that the Falcons follow the autumnal southward migrations of the Duck tribe, as I have several times observed that their first appearance hereabouts occurs exactly at the same time as that of our first autumnal wild fowl, Teal or Wigeon, for the former of which species the Peregrine has a very marked predilection. Besides the wild fowl, a good many Wood-Pigeons, Peewits, Starlings, Waterhens, and an occasional Partridge fall victims, but $I$ do not look upon the Peregrine in this county as such an enemy to game as the Sparrow- 
Hawk, which breeds with us, and has to supply the needs of four or five ravenous young just at the season when young Partridges and Pheasants offer an easy and tempting prey. But even allowing the game-destroying instincts of the present species, I would not on any account allow one of these really noble birds to be destroyed on my own property.

The proceedings of the Falcon are open and straightforward: as a rule she comes from the clouds like an arrow upon her prey, with a speed quite undescribable and incredible to those who have not witnessed it. The higher she is in the air the more certain her stoop, and the quarry is killed, if not at the first blow, as soon as her captor has recovered her breath; whereas the Sparrow-Hawk will begin to pluck and devour its victim whilst still alive and struggling.

Besides the above claim to protection from man, we should remember that the Falcon was our ancestors' principal sporting ally, and is surrounded by a halo of traditional associations which should entitle her to all respect. All this, however, has been urged so often by more able pens than mine, that I will not here continue my plea for my favourite bird, but refer my readers especially to that most excellent work ' Falconry, its Claims, History, and Practice,' by Messrs. Freeman and Salvin (London, 1859).

In a wooded and enclosed district such as ours falconry is, though not quite impracticable as I have personally proved, yet subject to so many obstacles and difficulties that few persons would care to attempt it; I am, however, glad to say that it is still carried on in various parts of England, Scotland, and Ireland 
with considerable success, and is in my opinion the pursuit which preeminently deserves the untranslatable title of sport. In the work just mentioned will be found, at p. 99, an amusing account of the method of catching Falcons for training in Holland. I only mention this for the reason that $I$ have adopted this same method in this immediate neighbourhood, and caught four wild Peregrines thereby. It is a somewhat remarkable fact that, although the great majority of Peregrines that I have known of, and seen shot and caught, in this county have been in immature plumage, every male has been an adult, or, at any rate, a twice-moulted individual*. I heard from one of my gamekeepers of his having seen a Falcon catch a Starling in the second week of August 1870 in this immediate neighbourhood. This is an unusually early appearance of this species in these parts. The Peregrine is known by many names amongst gamekeepers and others in various parts of the country. I have heard it called Blue-Hawk, Partridge-Hawk, Duck-Hawk, Bird-Hawk, \&c.; but I think since I have flown Falcons in these parts that the proper term Falcon, or some modification such as Falkner or Fawkenhawk, is generally used.

I have kept many Peregrines, both trained and untrained, and from my personal experience am inclined to credit them with a high degree of intelligence, and, against the generally received opinion, a capacity for attachment to man entirely apart from "cupboard love." But the truth is that there is just as much variety of disposition and physical constitution amongst Falcons certainly, and in all probability amongst other species of birds, as amongst dogs,

* This paragraph was written in 1876 , and no longer holds good. 
horses, or human beings, and it is in the study of these peculiarities that a great part of the falconer's art consists.

The Peregrine breeds almost invariably in cliffs both on the sea-coast and inland, and uses the same spot for that purpose year after year. I have often noticed in this neighbourhood that when a Falcon has established herself at one of the stands, or look-out places above mentioned, though she will occasionally tolerate the companionship of one other bird of her species, immediately that a third individual makes its appearance in her hunting-grounds a fight is certain to ensue, and the last comer generally has the worst of it. I on one occasion near this place saw a male Peregrine capture a Starling after some fine stoops high in air; he carried off his prey to the top of a high ash tree, and was instantaneously robbed of it by a female of the same species. I ought to mention that in this species, as in most birds of prey, the female is the largest and most powerful bird, and is the "Falcon" of falconers, the male being distinguished by the name of "'Tiercel."

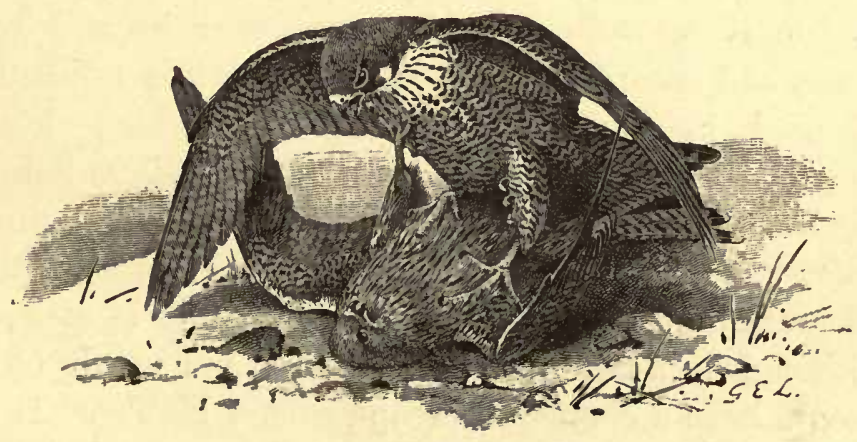

Peregrine and IKestrel. 


\section{HOB BY.}

\section{Falco subbuteo.}

The Hobby is a summer visitor to England and is by no means a very uncommon bird in this part of our county, where its nest is occasionally met with. Though less frequent with us than it was some twenty or thirty years ago, few summers pass without my observing one or more of these birds in this neighbourhood. In the month of September 1878, when Partridge-shooting near Tichmarsh, I repeatedly saw a Hobby in pursuit of small birds, and Mr. G. Hunt informed me that he observed one on several occasions during the summer of 1879 near Lilford. A female in adult plumage was shot by one of the gamekeepers here just outside the park in May 1875; and $I$ am acquainted with many occurrences of this species in various parts of the county. The Hobby may easily be distinguished from our other small Hawks by its remarkably long, pointed wings, and its habit of circling high in air without, so far as my observation goes, hovering as the Kestrel continually does. In pursuit of its prey the rapidity of the Hobby is marvellous, and the manner in which it turns and mounts after making a stoop is quite unrivalled by any bird of prey with which I am acquainted. In this neighbourhood this little Falcon seems to prefer Sky-Larks and Buntings; I have often seen it also chase Swallows and Martins; but this has seemed to me to be more in play than in earnest, although in a fair open field few of our small birds would have a chance of escape from a Hobby. It is, however, to a great extent insectivorous, and certainly 
feeds on chafers and other beetles, dragonflies, and grasshoppers.

The old works on Falconry mention the Hobby as having been often reclaimed and trained to take Larks and other small birds-but principally with the aid of dogs and nets, by a method called "daring," of which I quote the following quaint description from "The Book of Falconrie or Hawking, by George 'Turbervile, Gentleman, An. Dom. 1611,' p. 56:-“The doggs they range the field to spring the fowle, and the Hobbies they accustome to flee aloft over them, soaring in the aire, whome the silly birdes espying at that advantage and fearing this conspiracy (as it were) betwixt the dogs and hawkes, for their undoing and confusion, dare in no wise commit themselves to their wings, but do lie as close and flat as they possible may do, and so are taken in the nets, which with us in England is called Daring, a sport of all others most proper to the Hobbie."

In the estimation of the Falconer the Hobby has one great defect: in spite of its remarkable docility and marvellous power of wing, it is a bad footer, $i . e$. it lacks the power or the will to clutch its prey firmly. This, at all events, has been the case with all the reclaimed birds of this species that I have seen, and arises probably from the comparative delicacy and weakness of the legs and toes, which are better adapted for the capture of insects than of feathered prey.

The Hobby generally appears with us about the middle of May, and I think in most instances selects an old nest of the Carrion-Crow, Magpie, or WoodPigeon to lay in. The usual complement of eggs is three, though I have heard of instances of four young 


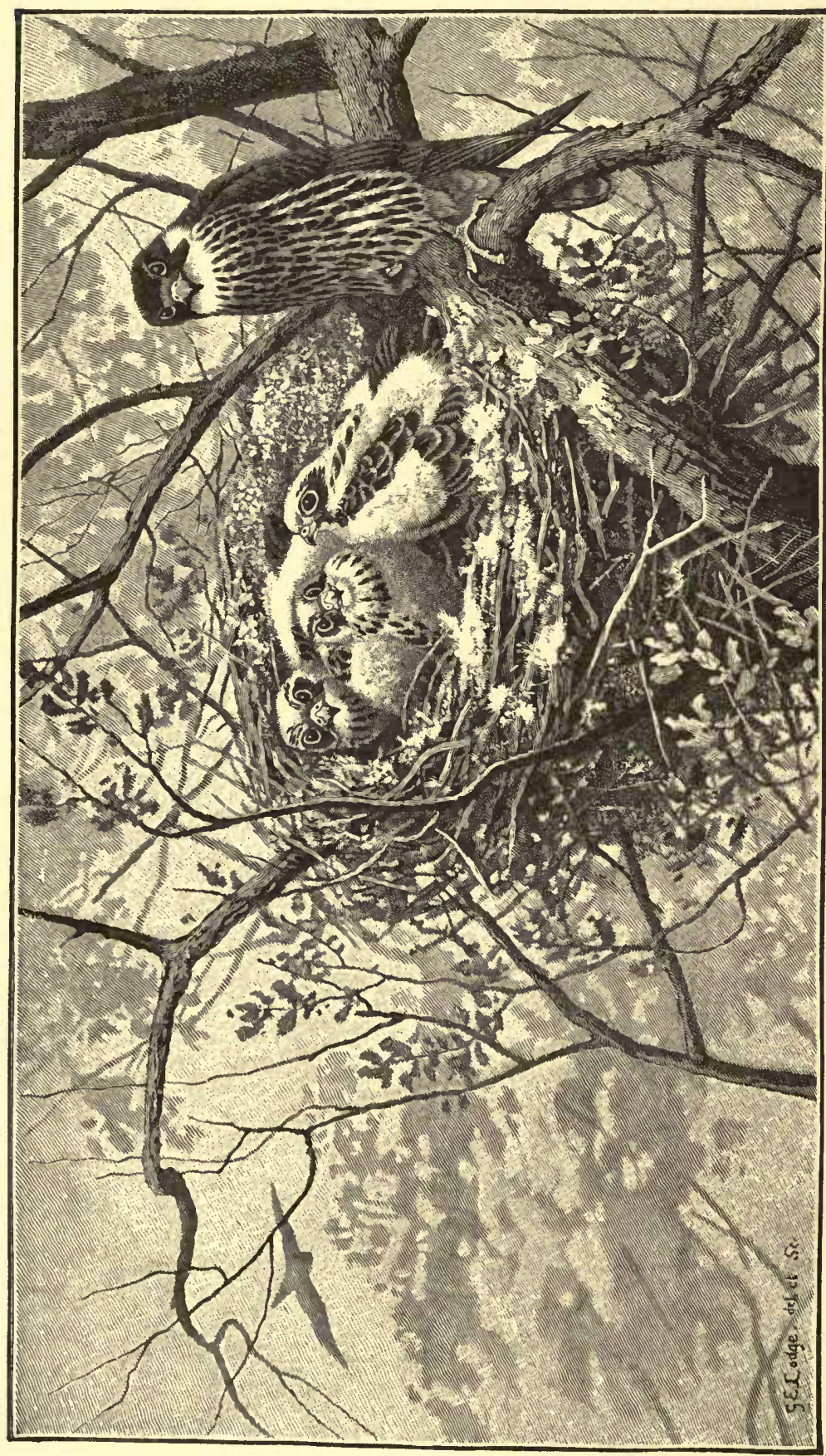

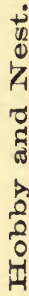


birds being found in the same nest. The eggs are of a dirty white ground-colour, thickly spotted and blotched with a reddish brown; and though they much resemble those of the Kestrel, are, I think, generally to be distinguished from those of that species by the lighter colour of the markings. But I need hardly say that almost all birds' eggs are subject to variety in colour, distribution of markings, size, \&c.; and there is such a general resemblance amongst those of our three British species of small true Falcons, viz. Hobby, Merlin, and Kestrel, that he would be a bold ornithologist who would venture confidently to assign a clutch of unidentified eggs to any one of the three species, though I admit that those of the Merlin have often a marked character to themselves. Many instances of the occurrence of the Hobby in England during the winter months are on record, but, as a rule, the bird leaves us about the end of September.

The Hobby is a very high-couraged bird, and, as I have more than once observed, will dash out and drive off a Crow, and other birds of prey much stronger and larger than itself, that may happen to approach its nest. The cry of this species much resembles that of the Wryneck, (though it is of course louder and stronger, and may often be heard late on a summer evening when the birds are chasing insects about the old oak trees, as is their habit), as also that of the Kestrel. I have heard of instances of the Hobby attacking Partridges, but though I have often been accompanied by one of these birds when out shooting, and chances have repeatedly offered themselves, I never saw the Hawk take the slightest notice of any game-bird, and consider it as entirely harmless in that respect. I have found this species 
delicate, and difficult to keep long in confinement, but it is a delightful bird as a pet, from its great docility and fearlessness, besides its preeminent beauty of plumage and graceful make. A Hobby may be trained in a few days to follow its master anywhere. I regret to say that my gamekeeper shot a beautiful adult male Hobby on August 26, 1879, by mistake for a Sparrow-Hawk, at a short distance from his house, and within half a mile from this. He told me that after shooting this bird he saw another of undoubtedly the same species within easy gunshot. It is my earnest wish to protect all birds of prey, except the Sparrow-Hawk and various members of the genus Corvus; but perhaps it is too much to expect of a gamekeeper to discriminate in these matters, though in this instance the error was recognized in time to save the life of (as I hope) the female parent of a brood of young Hobbies. I am glad to say that since this article appeared in the 'Northamptonshire Nat. Hist. Journal' the Hobby has certainly become very much more common in our neighbourhood than it was for many years previously. Between the years 1882 and 1890 inclusive I had positive evidence of the hatching-out of no less than ten broods of this species in our district, and sixteen nestlings were brought to me without, so far as I know, the destruction of any of the parent birds. 


\section{MER LIN.}

\section{Falco cesalon.}

This bird is one of the only three raptorial species mentioned by Morton in his 'Natural History of Northamptonshire' in the following words:- "The Merlin, which is credibly reported to breed with us upon Draughton Heath." Sir Charles Isham has kindly favoured me with an extract from the Diary of Sir Thomas Isham, of Lamport, translated from the original Latin by the Rev. R. Isham, which states: "Aug. 5, 1672, Clerk's son found a Merlin Hawk in its nest at a place called Haybrig." The Merlin was probably more generally known in those days than at present, as it was often used in Falconry, and as there was then a great deal of unenclosed and uncultivated land in the county, well suited to its breeding-habits, I see no cause to doubt the correctness of either of the above statements. So far as my own observation goes, the Merlin is now a pretty regular autumnal visitor to this part of the county. I have often seen it in this immediate neighbourhood in the months of October and November, and shot a young female close to this house whilst she was hovering over a hooded Falcon, which I had just placed upon a low wall, as I exercised another at the lure, on October 5, 1860. I well remember my father shooting a fine adult male of this species in Southern Wood many years ago, and there is a specimen in the same state of plumage in the collection at Wadenhoe that was killed at Bearshank Wood about 1872. There is a stuffed specimen of the Merlin at Bulwick Park, which was shot there, and besides those which I have 
myself seen, I am acquainted with many occurrences of this species in our county. I think that the Merlin preys exclusively on small birds, and the Meadow-Pipit seems to be a very favourite quarry. I have seen many very pretty flights in our meadows at this bird and also at the Grey Wagtail ; the Hawk comes flying low and fast along a fence side, or often along the windings of our rivers and brooks, till a small bird springs up before him, when an interesting chase ensues, which, in the case of the two species just mentioned, does not by any means always result in a capture, for I have several times seen the Merlin, apparently disgusted and wearied by continual unsuccessful stoops, fly off to a post or rail, whilst the Pipit or Wagtail went jerking away, with notes of self-congratulation on its escape. In Great Britain the Merlin generally nests on the ground, often on the steep bank of a burn in the moorlands, and occasionally on a tussock on the open moor. The eggs, according to Yarrell, are from four to six, but I have not met with an instance of more than the former number; they have the same style of coloration as those of the Hobby and Kestrel, but the tints are generally darker, and less of the ground-colour is visible than in those species; the eggs are also smaller and not so rounded as in those of the birds just named. 'Though the Merlin, as I have just stated, generally nests upon the ground, this is not always the case, and the following instance to the contrary, kindly communicated to me by F. Rooper, Esq., of Huntingdon, though not relating to our own county, occurred in its close neighbourhood, and is of such ornithological interest, that I make no apology for inserting it in these notes on Northamptonshire 
birds :- "A young Merlin was taken from a nest in Rotts Wood, near Whiston, Hunts, about June 23rd, 1874, by a man named George Phillips, who took it to the Rev. T. Woodruff, at whose house I often saw and handled it, and knew that it really was a Merlin; the nest was in an oak tree and contained five young nearly fledged." My friend Mr. Rooper is so fond of and so well acquainted with our British birds, that I feel convinced that there is no mistake here. In the fourth edition of Yarrell's 'British Birds,' vol. i. p. 76, I find it stated that in Lapland the Merlin commonly breeds in trees; and I have a somewhat hazy recollection of having been informed by the late Rev. James Boultbee (who was at the time Rector of Barnwell) that he had obtained young Merlins from the nest in Barnwell Wold, a large wood belonging to the Duke of Buccleuch, about three miles from this house,-probably well known to entomologists as a favourite locality for the Purple Emperor (Apatura iris) and other scarce butterflies, - where the Hobby formerly nested pretty regularly. The Merlin is a very bold little bird, and will fly at and occasionally kill birds of twice his own weight, as is mentioned by Yarrell. I myself have seen a pair of Merlins fly at an old Blackcock which passed near their nest, and though they did not kill him, they knocked him into the heather, with the loss of many feathers, and so terrified him that, though not seriously wounded, he all but allowed us to catch him. The Merlin is easily trained, and will take Larks, Blackbirds, Thrushes, and even Pigeons, but requires a peculiar mode of treatment-to be fed as much as possible upon live birds, and allowed more liberty to exercise his wings 
than is necessary or usual with other Hawks. I have often been assured by gamekeepers in Scotland, and on the moors in the north of England, that this species is very destructive to young Grouse, and as all Hawks prefer the quarry which is the easiest to take, I have no doubt that this statement may be true, but here, in our midlands, at all events, the amount of damage done to game by these occasional

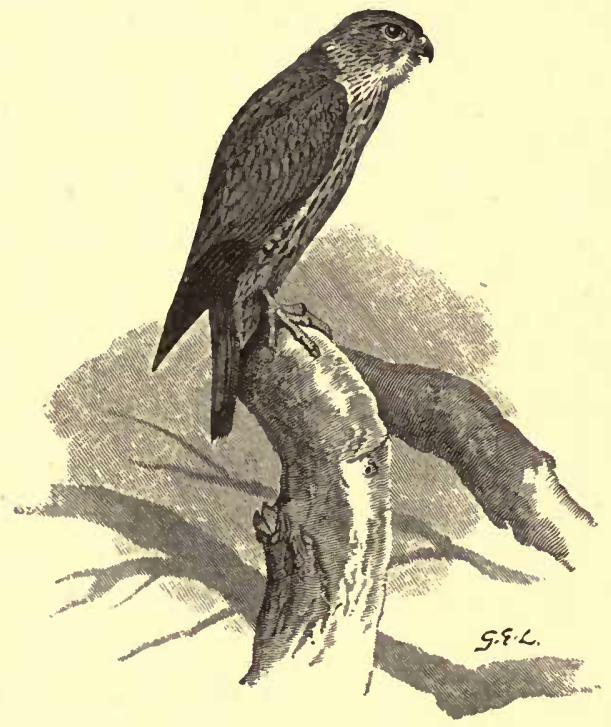

Merlin, adult male.

visitors must be infinitesimal, and, as I have repeatedly urged, the best rule a preserver of game can lay down, in the matter of what gamekeepers call " winged vermin," is to forbid the destruction of any birds except the Sparrow-Hawk and the members of the Crow tribe. The claims of the birds of prey to protection will gain nothing by over-statement, but I am convinced that the more we study their habits 
and make the most of our opportunities of observing them, the more we shall learn to believe that we cannot improve upon the "balance of power," if I may may be allowed the expression, laid down by Nature, and the advantages to be gained by this sort of study are too many and too obvious to the most ordinary intelligence to need further exposition by me.

\section{K E S T R E L.}

\section{Falco tinnunculus.}

The Kestrel is by far our most common species of diurnal birds of prey, and is so well known that it is unlikely that I shall be able to add anything new to the abundant records as to its habits and life-history. In this neighbourhood hardly a day passes during the spring and summer months that one or more of this species may not be observed hovering in the air over our fields and meadows, and occasionally darting down, to the ground upon a' mouse, grasshopper, or other such "small deer." The food, indeed, of the Kestrel is very varied, and to my knowledge it will take moles, mice, small birds, frogs, lizards, grasshoppers, beetles of many species, on wing and on the ground, and earthworms. I once, and once only, saw a Kestrel pursue any bird larger than a Sparrow or Greenfinch, viz. a Missel-Thrush; but though the Hawk in this instance seemed to "mean business," the Thrush held her very cheap, and sat chattering in a tree about which the Kestrel made many, apparently vicious, stoops. I think that in this county the Kestrel is generally known as Sparrow-Hawk and the Sparrow-Hawk as Blue Hawk, but I have also 
24 THE BIRDS OF NORTHAMPTONSHIRE

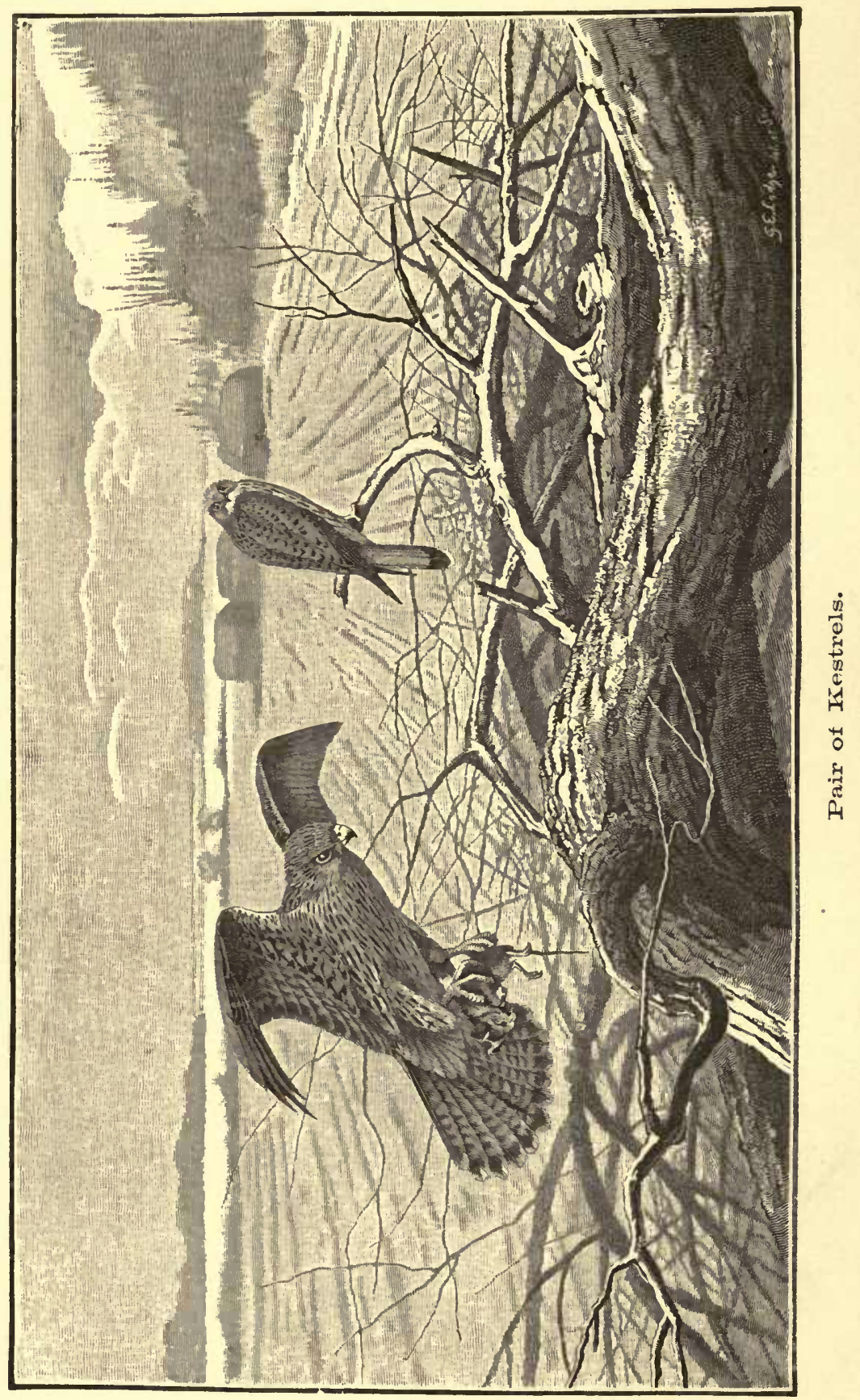


heard the old and very legitimate name of Windhover applied to the former. With us the Kestrel generally selects an old nest of the Carrion-Crow, or Magpie, in a tall elm, or, if available, a Scotch fir tree, in which to lay, though she sometimes builds a nest for herself, and sometimes, but in my experience rarely, chooses a hollow tree for her establishment. The eggs are generally four or five (I have known of six in a nest), of a mottled red-brown, but vary greatly in colour and in size. The young birds can generally fly before the end of May; and as I do my utmost to. prevent their destruction, I am often, when at home in the summer months, gratified with the sight of four or five of these pretty and useful birds on wing together. I cannot altogether acquit the Kestrel of an occasional bit of poaching; a small Partridge or Pheasant astray in the grass is no doubt too tempting a morsel to be resisted, but any petty larceny of this sort may well be condoned on account of the great number of field-mice and voles destroyed by these birds. The Kestrel is very easily tamed, and may be kept at liberty when once reclaimed, as it will, in common with most birds of prey, come regularly to call or whistle if fed at the same place and time every day, but it is of no use for falconry, as its natural mode of obtaining its prey, as I have already said, is by taking it from the ground, except in the case of certain winged insects which do not enter into the falconer's list of legitimate "quarry." I am inclined here to enter my protest against a fashion which is only too prevalent of shooting birds for the purpose of making their skins into hand-screens. I have seen portions of Kestrels, Owls, and many other birds (though few so useful as those just named), stuck 
upon handles with the head, legs, and feet in impossible positions between the wings, and with staring glass eyes, almost always of the wrong colour, doing outrage to ornithological decency and all the best feelings of those who love birds. Plenty of birds are destroyed for our daily use, in the way of game, poultry, and wild-fowl, to furnish screens for all who require them, without thinning the ranks of such birds as I have mentioned. Fragments of Pheasants, Partridges, Wild Ducks, Bantams, Guinea-fowls, \&c., will keep off the heat of the fire as well as others, and not entail unnecessary destruction.

A very large proportion of our Kestrels generally leave us on the approach of winter; in fact we seldom see one of this species in this neighbourhood between the beginning of December and March, but their movements of course depend upon the weather, and I recollect one very mild winter in which I did not perceive any diminution of their numbers till a sharp and prolonged frost, with some snow, in the early part of March, sent them off to some milder climate for several weeks.

\section{SPARROW-HA WK.}

Accipiter nisus.

The Hawk is very common in all our district, and in spite of the incessant war of extermination carried on against it, and with good cause, by preservers of game, I fancy that it is more common in our immediate neighbourhood now than it was some twenty or thirty years ago. I, personally, should be sorry to exterminate this or any other bird, but in a semi- 
preserved district such as ours, with large extents of woodland, dense coppices, and abundance of small birds, no amount of shooting will extinguish this freebooter, and I confess that I show him but little mercy.

The Sparrow-Hawk is a very bold and a very ravenous bird, but seldom affords one much insight into his proceedings. A warning note or two from a Sparrow or Finch, the plunge of a small dark body into a fence, a shriek of terror or agony, and all is over. Nor are the small birds just mentioned by any means the only victims; when a pair of SparrowHawks have young, and discover a brood of young Pheasants, Chickens, or Partridges, they will take one or more of these every day till there are no more to take, and I have seen a nest containing three young well fed Hawks crowded with the putrefying bodies of various birds which had not been touched as food, the old Hawks apparently only indulging in this extravagant slaughter to keep themselves in practice.

The great difference of size between the sexes of this species has led to much confusion amongst gamekeepers and others, and to the bestowing of many different names upon them, but one very simple distinction from all our other small Hawks may be mentioned for the benefit of the unlearned in birds, viz. that the Sparrow-Hawk has at all ages and in all seasons a yellow iris or circle round the pupil, whilst in the Hobby, Kestrel, and Merlin it is dark brown. As I have before mentioned, the SparrowHawk is a very bold bird, and has often been known to dash into a room, sometimes through a windowpane, at a caged bird. I have had my face sharply brushed by the wing of one of these Hawks, intent 
upon some young Partridges, and have several times known one of them to dart through the wire netting at the top of a Pheasant-pen, without injury to itself, though I found it impossible subsequently to pass the dead body of the Hawk through the meshes of the said wire. A good many Wood-Pigeons fall victims to the Sparrow-Hawk in the autumn and winter, when they are feeding on acorns and beech-mast in our woods. The Hawk sits motionless and well concealed in a tree till a favourable chance offers itself, when it dashes down, and seizing the Pigeon by the head and neck, soon puts an end to its struggles, in spite of the very superior strength of the captured bird. I have had but very little experience of this Hawk in a trained state, but in some instances have heard of it as very useful. The female will take Partridges, and both sexes will capture Quails, LandRails, Blackbirds, 'Thrushes, and smaller birds, but they are uncertain tempered, and somewhat difficult to manage, and with some few exceptions falconers do not care much about them. The system of training and flying these short-winged Hawks, viz. SparrowHawk and Goshawk (Astur palumbarius), is entirely different from that pursued with the Falcons, as the former are not hooded, and will not wait on in the air, but are flown from the fist, but I have perhaps already digressed too much from ornithology to falconry, and must return to my subject. The Sparrow-Hawk generally, I think, builds a nest for itself, usually well concealed and at no great height; the eggs are from four to six, of a bluish white, more or less streaked, spotted, and blotched with a deep red-brown, but are subject to infinite variation in colour. I have twice met with perfectly unspotted 
eggs in a Sparrow-Hawk's nest, and often with specimens in which the brown markings are almost confined to a broad zone near the thick end of the egg. There is often a difference of from 3 to 4 inches in length between the female and male of this species, the male, according to Yarrell, averaging above 12 inches, and the female about three more, but I once shot a female which measured over 16 inches, and, though I have kept no record, am very certain that I

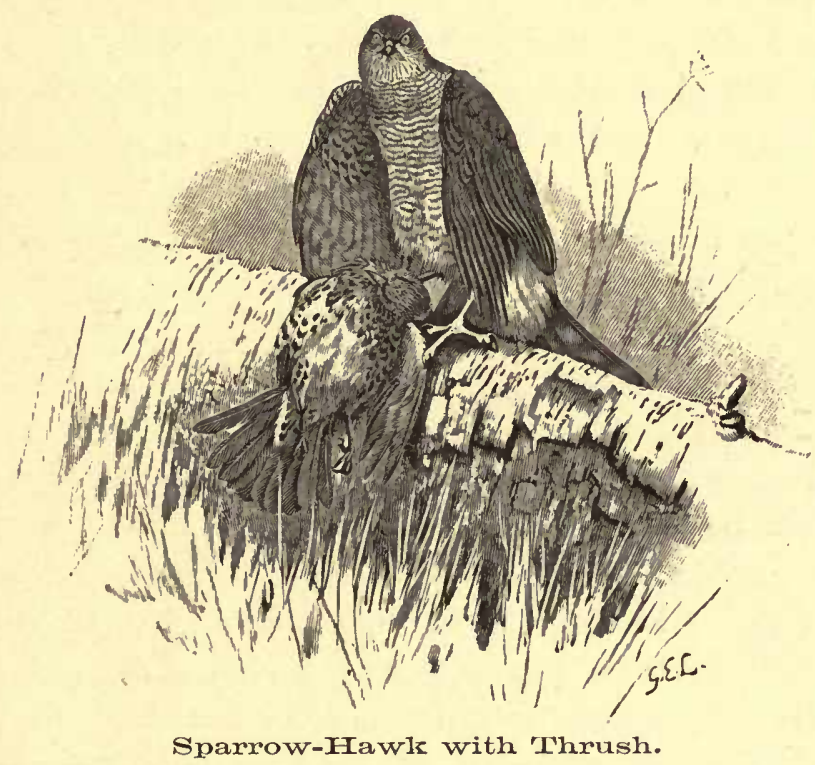

have often handled male birds which would not reach 11 inches. I have more than once known of instances of this Hark being taken in traps baited with a hen's egg for Carrion-Crows or Magpies. In this neighbourhood we generally have an arrival of migratory Sparrow-Hawks about the end of harvest, but it is difficult to say whether they are bona fide travellers or only natives, who take to the open fields from 
some of the large unpreserved woodlands in our vicinity; be that as it may, the greater number of those that we kill at that season are not birds of the year, and as winter approaches make themselves scarce. This Hawk in captivity is very subject to cramp, and will not bear much exposure to the weather. The females will kill and devour the males if left together, and they have the unpleasant peculiarity of being one day perfectly tame and sitting quietly on the fist, and the next, perhaps, struggling and dashing themselves nearly to death on the approach of their master, who has carried them for hours, and from whose hand they have constantly been fed.

\section{K I T E.}

Milvus vulgaris.

Of this fine bird and its habits in this county, or indeed I may say in this country, I am sorry to say that, from personal observation, I have next to nothing to relate, for the obvious reason that the species has been all but extinct in our district for nearly fifty years, and is now a rare bird in all parts of Great Britain. My own acquaintance with the Kite in Northamptonshire is soon told. I can just remember, during a very severe frost with snow upon the ground, being taken out in front of the house to look at three Kites sailing at no great height over the lawn; this must have been in the winter of 1837-38. On another occasion I saw a Kite close to Milton, Peterborough, perhaps some four or five years later than the above instance; and 
in $1843 \mathrm{I}$ well recollect one of our gamekeepers bringing in a fine Kite which he had shot from his cottage door near Aldwincle. In the last-named and following years Kites' nests were taken in Lady Wood and Great Wadenhoe Wood; in the latter instance by the late Mr. Norwood, of Salisbury, who gave me this information, and in 1840 or 1841 two young Kites were taken from a nest in a very large

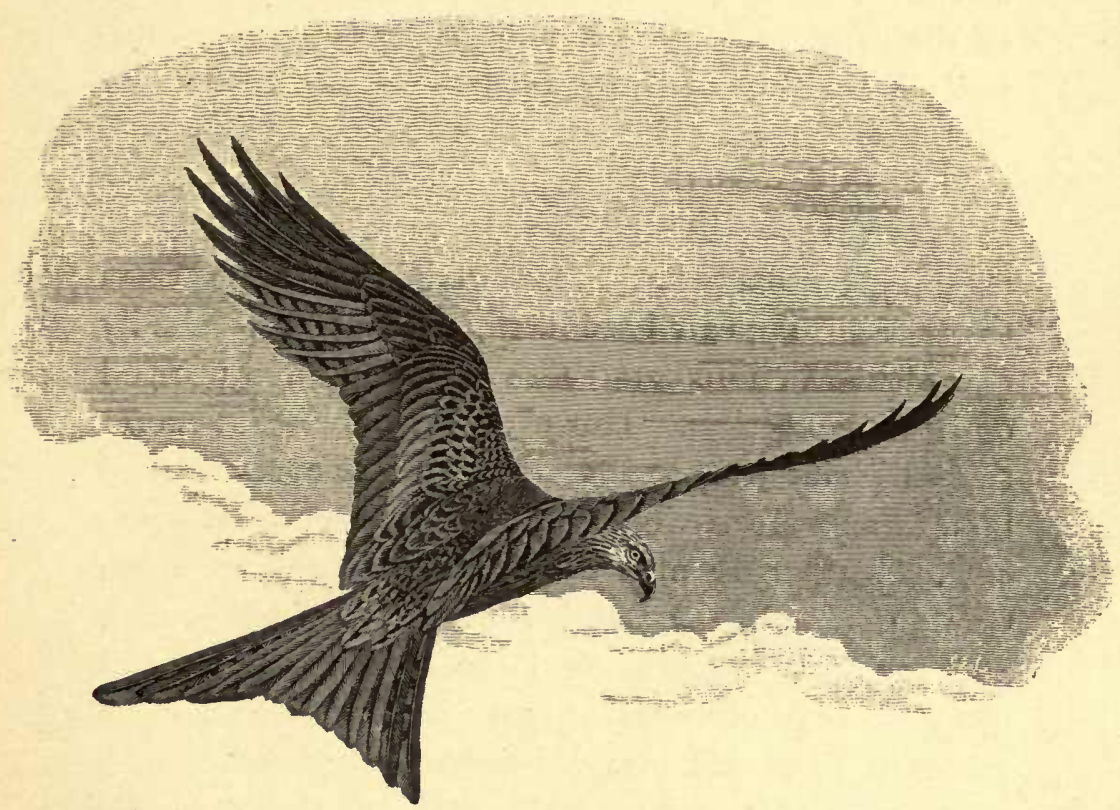

Soaring Irite.

elm near Barnwell village, and kept for many years in the rectory garden by the late Rev. J. Boultbee, in whose possession I well remember seeing them, and to whose daughter I am indebted for the above particulars; these birds made a nest in the garden just named, and laid two eggs, one of which was given to me by Mr, Boultbee. 
I have numerous records of the former abundance of the Kite in this division of our county, and especially in the great woods of HuntingdonshireMonk's Wood, Holme Wood, and Alconbury Hill. One of my correspondents seems to think that the drainage of the fens and of Whittlesea Mere has something to do with the disappearance of the Kite, but I cannot agree in this view, as the bird was already exceedingly rare at the time of the drainage of the mere, nor are meres or swampy ground especially attractive to it. I have also heard it stated that the Kites were exterminated by a very severe winter, and this I think is more likely, for although most of the records sent in to me are somewhat vague as to date, from what I can gather our Kites seem to have disappeared suddenly, and not gradually diminished in numbers as though shot and trapped off by gamekeepers. However this may be, it seems that till about 1844 or 1845 the Kite was common, and bred in many localities besides those above mentioned, e. g., 'Thistlemore near Milton, Rockingham Furest, Oundle Wood, the neighbourhood of Uppingham, and probably many other large woods. 'The latest record I have of the appearance of a Kite in these parts is from Mr. G. Edmonds, of Oundle, who informs me that in November 1868 one of these birds suddenly rose from a ditch within a yard of him, where it was regaling upon a dovecot Pigeon; this occurred in St. Osyth's Lane, within a very short distance of Oundle.

I presume that in England the Kite was a permanent resident, but I can find no positive information upon this point; at all events it nested regularly with us, and I recollect its presence, as before stated, 
on one occasion in the depth of winter. I have in my collection a fine specimen of this bird presented to me by the Rev. W. Finch Hatton, rector of Weldon, near which village it was shot from its nest many years ago by the late John Milley, gamekeeper to Lord Winchilsea; there are also Northamptonshire Kites (stuffed) at Burghley House, and at Bulwick Park. It seems that this species lingered in the county of Lincoln for many years after it had become extinct, or very nearly so, with us. I myself saw three Kites rise together from a railway embankment near Lincoln, in September 1850, and I am indebted to the kindness of Mr. John Cordeaux for the information that some Kite's eggs were taken from a nest in Bullingdon Wood, near Wragby, in the last-named county, as lately as 1870 , and, though I have not the reference at hand, I think that Mr. Cordeaux has since that time recorded the appearance of one or two Kites in his neighbourhood, viz. North Lincolnshire.

I have occasionally seen this species in Scotland, where, however, it is now exceedingly rare, and in Wales, where it still breeds, and whence I have received young birds alive.

In many parts of the continent of Europe the Kite is still common, especially in Spain, where, though not perhaps so abundant as the Black Kite (Milurs migrans) in the central and southern districts, it is constantly to be seen circling alone or in pairs about the villages, on the look-out for chickens, refuse, or materials for its nest, which is often built of somewhat curious materials. The late John Hancock, of Neweastle-on-Tyne, informed me that a nest in his collection, taken many years ago in Rockingham Forest, "was composed externally of sticks. from $\frac{1}{2}$ 
inch to 1 inch in diameter; the lining was a bit of a saddle-girth, a bit of red worsted binding, a harvestglove, and sundry pieces of paper and linen." A Spaniard who accompanied me in my bird-collecting rambles in Central Spain, in 1865, assured me that he had once taken a purse containing nine dollars from a Kite's nest, and I first learned the news of the murder of President A. Lincoln from a scrap of a Spanish newspaper found in a nest of this bird near Aranjuez.

The Kite was a very favourite object of pursuit in the palmy days of falconry, and, from its great powers of wing and habit of mounting high in air, afforded magnificent sport; the Falcons used appear to have been one or other of the northern species, Falco candicans, $F$. islandus, or $F$. gyrfalco, and the Saker, $F$. sacer. The flight of the Kite is easy and graceful; in common with some other birds of prey, this bird will scar in circles, sometimes for hours, with hardly a perceptible motion of the wings, but with an occasional shift of the forked tail.

It is a bird of no great courage, and is often driven off by Ravens and even by Magpies. Its cry is a wild plaintive squeal, which, though not very musical, has a certain fitness with the rugged scenery of hill and wood amongst which the bird is so frequently seen. The nest of the Kite is generally built in a high tree (in Spain the stone-pine is a favourite nesting-site), and lined with a very mixed mass of materials, wool, rags, dry grass - in fact almost anything portable that the birds can find in their favourite foraging-grounds, the outskirts of towns and villages; I do not, however, recollect to have ever seen feathers used as a lining for the nest. The eggs are generally, three, 
often only two, of a dirty white, spotted and streaked with reddish brown. I imagine that the Kite must always have been a far greater enemy to the poultrykeeper than to the game-preserver from the habit above mentioned.

Nature, I think, evidently intended the Kite as a scavenger, and in the southern countries of Europe the services of this and other species of birds in that way are by no means unimportant, as they are the only inspectors of nuisances, and have a strong, though not a pecuniary, interest in their removal. Literally nothing that any bird will eat comes amiss to the Kite; and from my acquaintance with him in captivity, I am inclined to think that he prefers his food somewhat high. I have seen a Kite devour rotten cabbage-stalks, scraps of bread, potatoes, fish, flesh, and fowl, fresh, high, and putrid, and complacently swallow pieces of stiff leather. The Black Kite allucled to above is common in Spain and many other parts of the continent, but has hitherto only been met with once in this country, viz., at Alnwick, Northumberland, in May 1866.

\section{COMMON BUZZARD.}

Buteo vulgaris.

The Buzzard has in this county shared the fate of the Kite, and is now a rare bird with us, thoigh still to be found in various parts of England, Wales, and Scotland, especially on the north and south coasts of Devonshire, where it nests, and where I have frequently observed it. I remember 


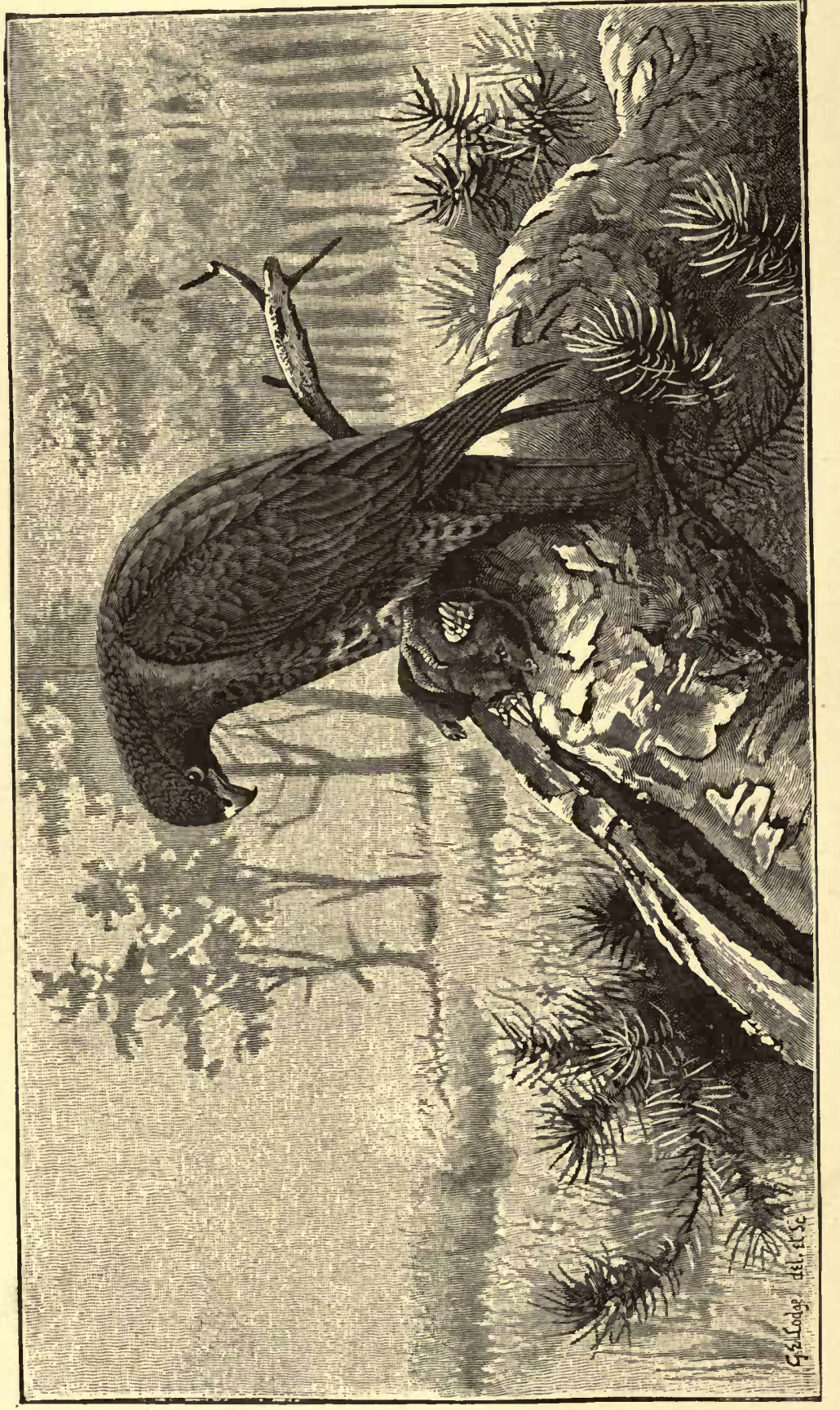

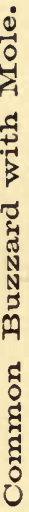


having seen a Buzzard or two occasionally in this immediate neighbourhood; the last, I feel pretty certain, was in the summer of 1846 , but I have been assured by very many persons, older than myself, that some sixty or seventy years ago it was as common as the Kite, and bred regularly in our large woods. Old John Milley, above mentioned as having shot the Kite near Weldon, declared that he had shot "scores of Buzzards of two kinds." 'The Rev. M. Berkeley kindly informs me that he remembers the Common Buzzard as breeding commonly in Oundle Wood, and I was informed by an old gamekeeper, formerly in the service of Mr. Watts Russell, of Biggin, that he used to kill two species of Buzzard, not uncommonly, in that neighbourhood about 1823-24. To this other species I shall make reference further on. Another old gamekeeper, who had been in the employ of my grandfather, my father, and myself, and died some years ago at the supposed age of 93 , often told me that in his early days Marten Cats, Kites, and two sorts of Buzzards were very common, and that he "counted the Brown Buzzard as very bad for young game and rabbits, far worse nor the Kites." The Buzzard, though often to be seen in the pairing-season soaring in the air, is a somewhat sluggish bird, and sits in a tree on the look-out for its prey-young rabbits, mice, rats, moles, and young or wounded birds; I do not know that it will feed on carrion.

The nests of this species which I have seen in this country have all been in cliffs, and most of them in spots very difficult of access, but in Spain, where the bird is pretty common, I have found the nests 
generally situated at the first large branch of a tall fir tree, but I think the old nest of some other species is often occupied by this species.

The eggs, two or three in number, are of a dirty white, sparingly marked with spots of light reddish brown, and are somewhat smaller and rounder than those of the Kite. The Buzzard has a plaintive wailing cry, to which it gives frequent utterance at all times of the year.

There are certain parts of England in which this species appears as an irregular bird of passage, not remaining long; but all birds, and very notably the birds of prey, are so much influenced by local causes, weather, abundance or scarcity of food \&c., that it is difficult in many instances to assign positively the epithets migratory or sedentary. The only comparatively recent occurrence of the Buzzard in Northamptonshire, of which I have record, was in January 1866, when one, which had been seen several times previously, was killed in Blatherwycke Park, near King's Cliffe, as I am informed by Mr. A. G. Elliot, of Stamford.

Since the above article appeared in the 'Journal of the Norths. Nat. History Society,' a few more instances of the occurrence of the present species in our county have come to my knowledge; as I have already recorded most of these in the pages of the 'Zoologist,' I do not go into details here. A Buzzard was shot in Geddington Chase in May 1882, and sent to me stuffed in 1887. About the middle of November 1883 a Buzzard was heard by me, and subsequently seen and clearly identified by several persons in the neighbourhood of Wadenhoe and Lilford. In the 
first week of September 1888 a Buzzard haunted the park and pleasure-grounds at Lilford for several days. A Buzzard, that had been haunting our woodlands for some weeks previously, was killed by one of Lady Cardigan's gamekeepers about the end of December 1888, and allowed to rot. The Rev. Henry H. Slater, of Irchester Vicarage, informed me that he saw a passage of four Buzzards together, in that neighbourhood, on September 26, 1892.

\section{ROUGH-LEGGED BUZZARD.}

Buteo lagopus.

This is a species with which I have very little personal acquaintance, except in captivity, having only occasionally seen one on the wing in the open country of West Norfolk and Suffolk during the winter months, and never having visited its breedinghaunts in the north of Europe. In England the Rough-legged Buzzard occurs usually as an autumnal or winter visitor, and on our north-eastern and eastern coasts can hardly be considered rare. In this county I know of three instances of the occurrence of this bird; but have little doubt that it has been met with frequently, and not recorded. Mr. George Bannerman, writing in 'The Field' of February 12th 1876 , mentions the death of one of these birds near Brackley in the previous December. I have recorded the capture of another at 'Thrapston, in November 1875 , in the same newspaper of February 19 th, 1876. and a large bird of prey, which (as I was laid up at 
the time of its visit) I did not myself see, was constantly seen and watched in the immediate neighbourhood of this house, in the months of December 1876 and January and February 1877, by various trustworthy persons, from whose detailed accounts I have no doubt of its having been one of the present species. I would not allow it to be shot at or molested in any way, and it appears to have become very fearless and permitted a near approach ; it was constantly persecuted by Rooks and Crows, of which it took little notice, but finally disappeared about the middle of February. The Rough-legged Buzzard may be easily distinguished from the common species, when seen from below, by its larger size and generally by the greater amount of white on the lower parts. 'I'here are authentic instances on record of the breeding of this species in England; but these are exceptional; the true home of the bird is in Northern Europe and Asia, where it is reported to prey upon small mammalia and water-fowl, and to nest generally in trees, but occasionally in cliffs. Several Roughlegged Buzzards, which I have kept in confinement, seemed quiet, sluggish birds, by no means wild, and lived peaceably with various other birds of prey. I never heard them utter any cry.

For other supposed occurrences of this species in Northamptonshire without capture or positive identification, cf. my communications to 'Zoologist,' dated November 20, 1885, January 20, 1891, and December 12,1891 . 


\section{HONEY - B U Z Z A R D.}

\section{Pernis apivorus.}

I feel no doubt that this is the second species of Buzzard mentioned by the ancient gamekeepers, as I have stated, as formerly common and breeding in the woods of our northern division. The Kite was, of course, well known to them, and from its colour and forked tail there could be no mistake; the Roughlegged Buzzard is an autumnal visitor, and when it does visit us almost always keeps to the most open country it can find, whilst the present species is a regular summer migrant to most parts of Europe, and has bred, to my knowledge, in this county, as I have a specimen kindly presented by the Rev. W. Finch Hatton, which was shot, with another, from a nest containing four eggs in Core Thick, near Wreldon, in the summer of 1843 or 184 t. I saw another of these birds stuffed at Wansford, which was shot in that neighbourhood many years ago; and there is, or was, another in the possession of Mr. T. Sharman, of Benefield Grange, which was shot in that neighbourhood in $\mathbf{1 8 6 2 .}$

I have never seen this bird alive in this country, except in captivity, but in some parts of the continent it may be called abundant as a summer visitor, and I once witnessed the passage of many hundreds over the Straits of Gibraltar, on their travels southwards, in the month of September 18j6. We were becalmed off Europa Point, and from about mic'day till dusk these birds kept passing in small flocks of from five or six to eighty at intervals of a few minutes, at no very great height, though generally out of gunshot. 
This passage occurs regularly twice a year, in May and September, but it is a curious fact that we never; to my knowledge, saw a Honey-Buzzard in any part of Andalucia or Central Spain, though we found it nesting in the mountain-forests of the province of Santander in May 1876. The food of the HoneyBuzzard appears to consist chiefly, if not exclusively, of the grubs of wasps and bees, which it scrapes out of the ground. It is a perfectly harmless, in fact a useful bird, not by any means naturally shy or wild, and, no doubt, would be a common summer visitor to our woods if, in common with so many other species, it were not shot down immediately it makes its appearance in our country. It is incapable of doing injury to game, and the only reason for killing it is the fact of its being a rare bird, the very reason that ought to operate in the contrary direction.

The Honey-Buzzard, so far as my own observation of its habits extends, seldom remains long on the wing, but loves to sit and take the sun upon a dead bough of some lofty tree, evincing a very decided preference for the beech, and, when disturbed, merely flies a short distance, to take up a similar position. The food of this species, of course, compels it to be often on the ground, upon which I have seen it run with ease and some speed in a manner quite different to the terrestrial progression of any other European bird of prey. In the few instances in which I have known of the nest, it has been placed in a beech, on a large bough close to the trunk of the tree, at some thirty feet from the ground, built of strong sticks externally, with small beech-twigs internally, and a lining of fresh green beech-leaves. The eggs are generally three, of a roundish oval, and are often 


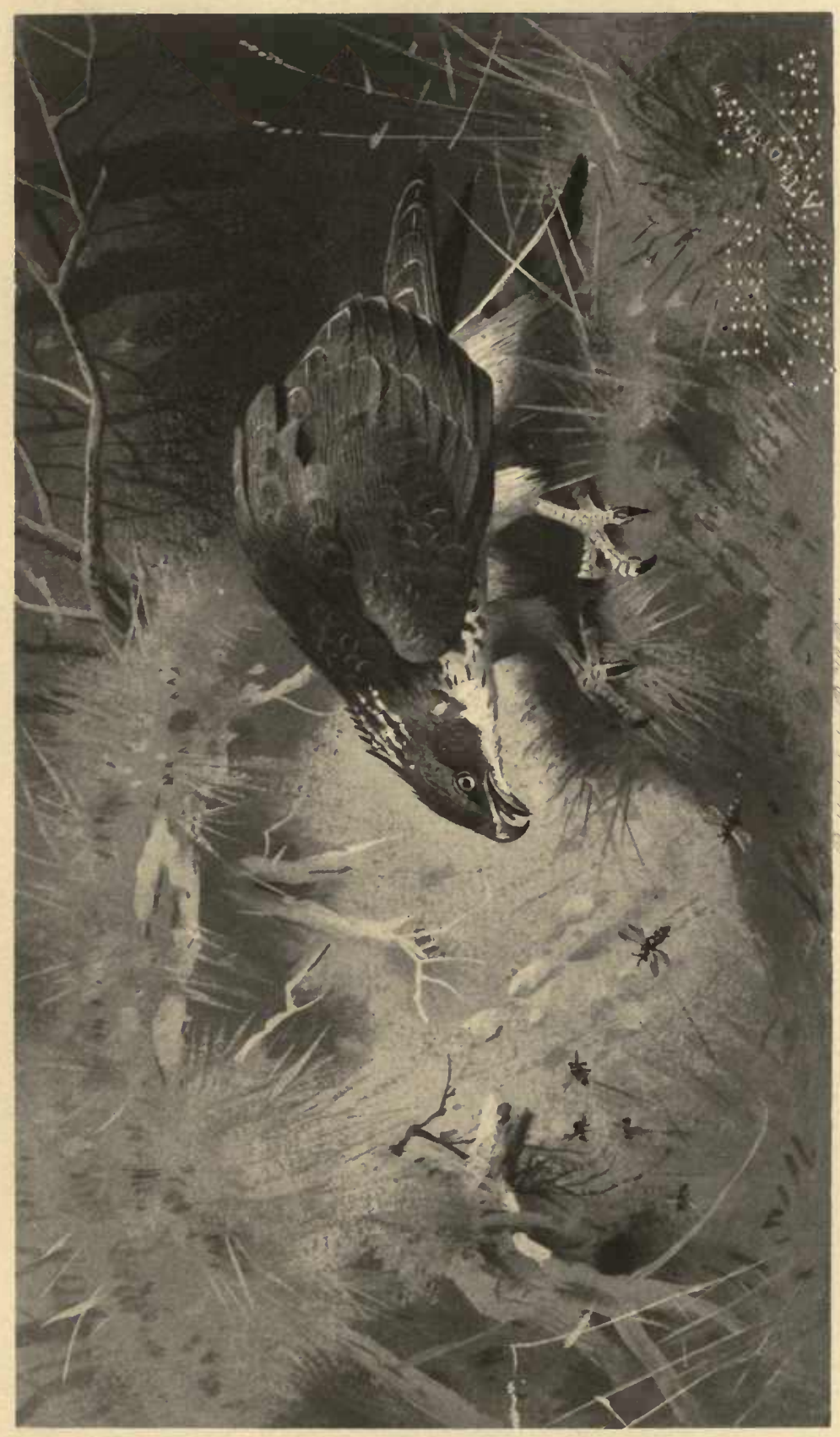



almost entirely clouded with various shades of dark red-brown on a dirty-white ground; some have less colour, but almost all that I have seen are very much more coloured than any eggs of the Common Buzzard or Kite.

The late Mr. E. C. Newcome told me the story which I see quoted, on his authority, in the fourth edition of Yarrell's 'British Birds,' about the HoneyBuzzard building a sort of leafy wall round its nest with fresh boughs. I have not myself seen this, but have no doubt whatever of the perfect accuracy of my informant, who was an excellent observer, and particularly well acquainted with raptorial birds, being quite the first practical falconer of his day. It is difficult to imagine the use of this wall, except perhaps for shade; but in the case of the nests met with by us, there was no need of a screen from the sun, as they were in deep shade at all hours of the day.

On March 26, 1891, I received the following reply to my inquiry concerning an occurrence of a HoneyBuzzard near Syresham many years previously, reported to me by Mr. W. Tomalin:- "Salcey Forest, March 25. I beg to say, in answer to your letter, that the Honey-Buzzard was pulled out by me in the Crown Woods near Silverstone, in this county, in September 1861. On seeing the wasps unusually busy one morning about 8 o'clock, I went near the nest to ascertain the cause. The whole of the combs were scratched out, and there was a hole nearly the size of a bee-hive, On seeing the tail of a bird, I put my arm in and drew out what proved to be a very fine specimen of the Honey-Buzzard. I sent the bird to a man named Dickins for preservation, but, having 
been badly stuffed, after about ten years it crumbled to pieces.--'l'hos. Gulliver, Crown Woodman."

A male of this species was shot at Milton, near Peterborough, in the summer of 1890 , stuffed by John Evans of Bourne, and is now preserved in the Peterborough Museum.

\section{M A R S H - H A R RIER.}

Circus ceruginosus.

This bird, formerly so abundant in the fens and marshy districts of England, where it was generally known as the Moor-Buzzard, I have only once met with in Northamptonshire, and much regret that I have no record of the exact date. It was, however, in a winter between 1860-65; I was looking for wild fowl and Snipes along a brook between Aldwincle and Thrapston, and had just fired both barrels at some Snipes, when a fine Marsh-Harrier, with the dark plumage and yellow head of immaturity, rose within some thirty yards of me from the brook-side, and sailed away to the northward. I never even heard of another in our neighbourhood,-which is remarkable, as before the draining of Whittlesea Mere and the adjoining fens the bird was exceedingly common thereabouts; our river-valley is near that district, and, one would suppose, presents sufficient attractions to a marsh-loving bird to induce it to extend its travels occasionally in our direction.

This is one of the most widely distributed of our European birds of prey, and, from my own observation, I should be inclined to say one of the most 


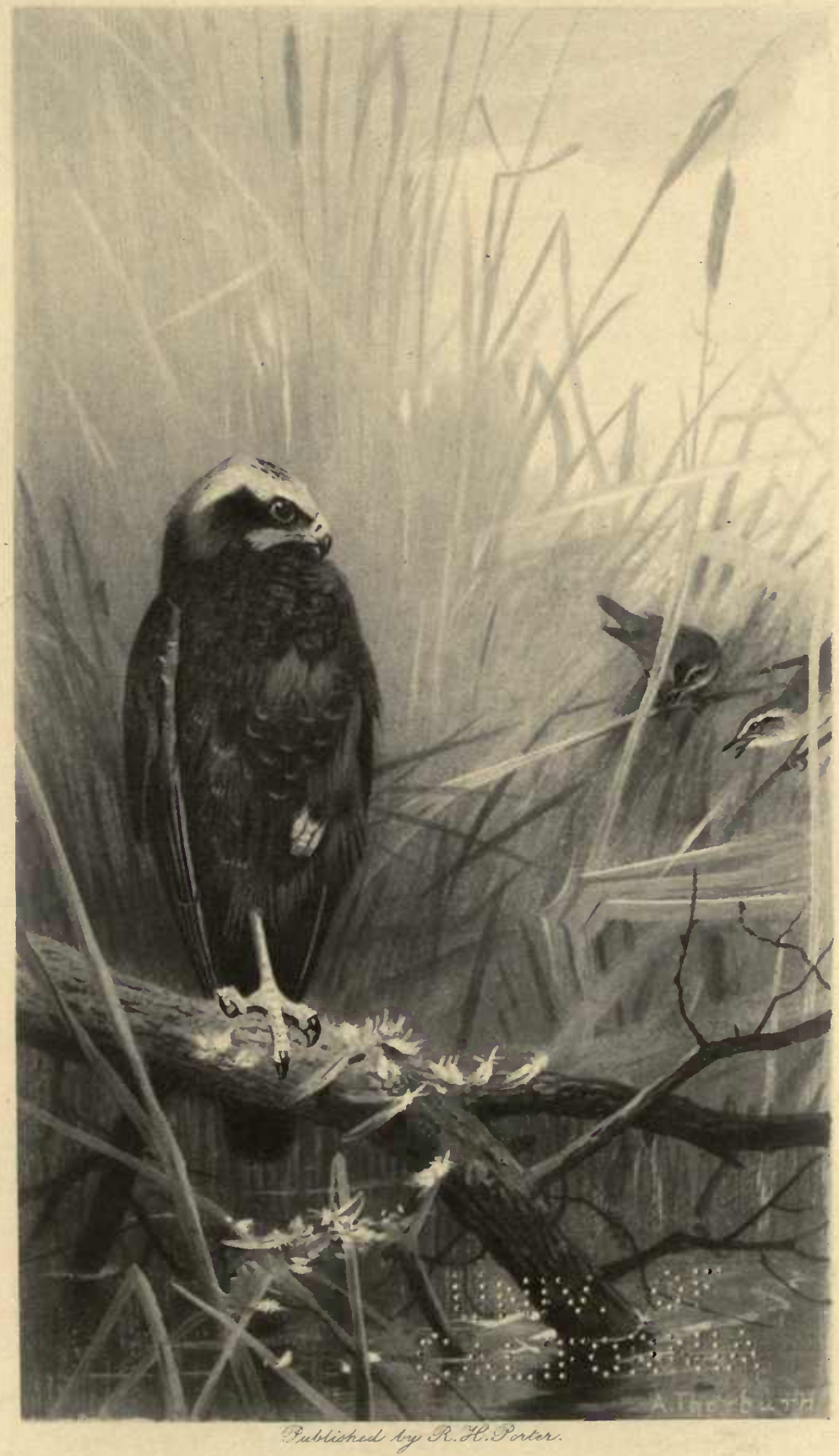

Marin- Harrien immature 

abundant in all localities suited to its habits. It has been driven away from its old haunts in England by the draining and cultivation of the fen-lands, and ruthless persecution, but I have met with it in Cambridgeshire and East Norfolk, in Merioneth, Cardigan, and Caermarthenshire, in various parts of Ireland, in France, Spain, Portugal, Sardinia, Sicily, Algeria, Tunis, Greece, European Turkey, Crete, and Cyprus. The Marsh-Harrier is a slow-flying bird, and appears to be constantly on the search for food. We often noticed twenty or more of this species on the wing together about the reedy marshes of Albania, where a wounded Snipe had very little chance of escape from them. I never saw a Marsh-Harrier attack any unwounded bird, but they do, no doubt, occasionally take young Water-fowl, and are great devourers of eggs. All the Harriers seem to have regular beats, which they quarter over at no great height several times each day, and are continually picking up something: the stomachs of two which I examined contained the remains of frogs, a half-digested snake, a vole, and some snail-shells. 'The nest is generally on or close to the ground, sometimes on a low bush amongst the reeds, and is built of sticks, pieces of reed, dry flags, and sedge; the eggs are three or four, rarely five, of a greenish white, occasionally faintly spotted with rust-colour. The female, whilst sitting, is fed by the male bird, who hovers over the nest and drops the prey to his mate. The conspicuous light-coloured head of the immature birds of this species has gained them the name of Bald Buzzard; but that name has also certainly been applied to the Osprey. 


\section{HEN - H A R R I ER.}

\section{Circus cyaneus.}

This is another of the many species which has been "improved" out of the country by the drainage of fen-lands, and perhaps still more by the enclosure and cultivation of the great stretches of furze and sedgecovered commons in which it delighted. I am not acquainted with a single instance of the death or capture of a bird of this species in Northamptonshire, but few autumns pass without my seeing at least one in this neighbourhood, and it is somewhat remarkable that, of perhaps twenty that I have observed hereabouts, I can only call to mind two which were not in the ash-grey plumage of the adult male. I have several times heard from the gamekeepers of their having seen a "Sea-Gull-coloured Hawk," and the Hen-Harrier certainly nested in my boyhood on some rough sedgy fields in the neighbourhood of Clapton. In the aforesaid grey plumage, and beating backwards and forwards over an open field, as is its habit, it is a conspicuous bird, and not likely to escape notice, but with the exception of the vague gamekeeper's account above mentioned, a note from Lady Mary Thompson of the former occurrence of the species near Milton, and an instance of its having been seen by Mr. G. Edmonds near Oundle about thirteen years ago, I have no local information on record concerning it. I have met with the Hen-Harrier in Devonshire, Norfolk, Scotland, Ireland, Wales, and various foreign countries, but nowhere in such abundance as in Northern Spain, in the neighbourhood of Santander, a country of open, undulating, rushy and furze-grown 
pastures, with occasional marshes, in every way admirably suited to its habits. Though I believe the principal food of this species to consist of reptiles and mice, for the capture of which it is, by its owl-like flight, admirably adapted, it is also most destructive to the eggs and young of ground-nesting birds, the Lapwing or Peewit being a frequent sufferer. The Harrier also frequently surprises full-grown birds on the ground by its stealthy and noiseless approach, with which it would stand no chance in a trial of speed on wing. My companion in the north of Spain shot a fine adult bird of this species from the remains of a full-grown Turtle-Dove, which it certainly could not have caught in fair flight. In various parts of our islands the Hen-Harrier is known by various names; in Devonshire it is Vuzkit, i.e. Furze-Kite; in Scotland I have heard it called Blue Glead; in Ireland Goshawk, no doubt properly GorseHawk; whilst the female seems to be generally known as Ringtail. The nests of this bird which have come under my notice were composed of a mass of dry sedge very loosely put together on a bare spot amongst furze and heath; once on a ledge on the bare stony bank of a Highland burn. The eggs are generally four (I have heard of six), of a bluish white, sometimes faintly freckled with small rust-coloured spots. I have never succeeded in keeping this species in captivity for any length of time, and have found those which I have so kept wild and sulky.

Since the above article appeared in our Nat. Hist. Journal, $I$ have become possessed of an adult female of this species, killed by a gamekeeper near Collyweston, about the middle of November 1890 . 


\section{MONTAGU'S HARRIER.}

Circus cineraceus.

The only specimen of this Harrier that I ever heard of in Northamptonshire was shot in a piece of standing barley near Thorpe Waterville, on August 31, 1894; the lout, who must have shot it at very close quarters, could not find it, but it was found alive, with both wings broken; by a man who was mowing the barley with a máchine; he picked it up, dashed it against the machine, and threw it away, but fortunately told his employer of the occurrence. The latter, who is a tenant of ours, went to look for it, found it, collected all the feathers that he could find, killed it (for the unhappy bird was still alive), and sent. it to me, thereby making ä valuable addition to my list of countỳ bircls.

Montagu's Harrier is a summer migrant to our Islands, and occaisionally nests in various parts of England, though it is seldom allowed to rear its young in peace. In all its habits it closely resembles the Hen-Harrier, but is a smaller and more slenderlymade bird. 'From what I read in the 'Zoologist,' the 'Field, and other publications, as well as from private correspondence, I am disposed to consider this species as by far the most common of the three British Harriers in England at the present time. It was fist distinguished from the Hen-Harrier by Colonel Montagu in 1802, but has probably often been mistaken for that species by subsequent writers, although it is very distinguishable, when on wing, by the darker grey mantle of the old males, and the smaller size, greater proportionate length of wings, more 


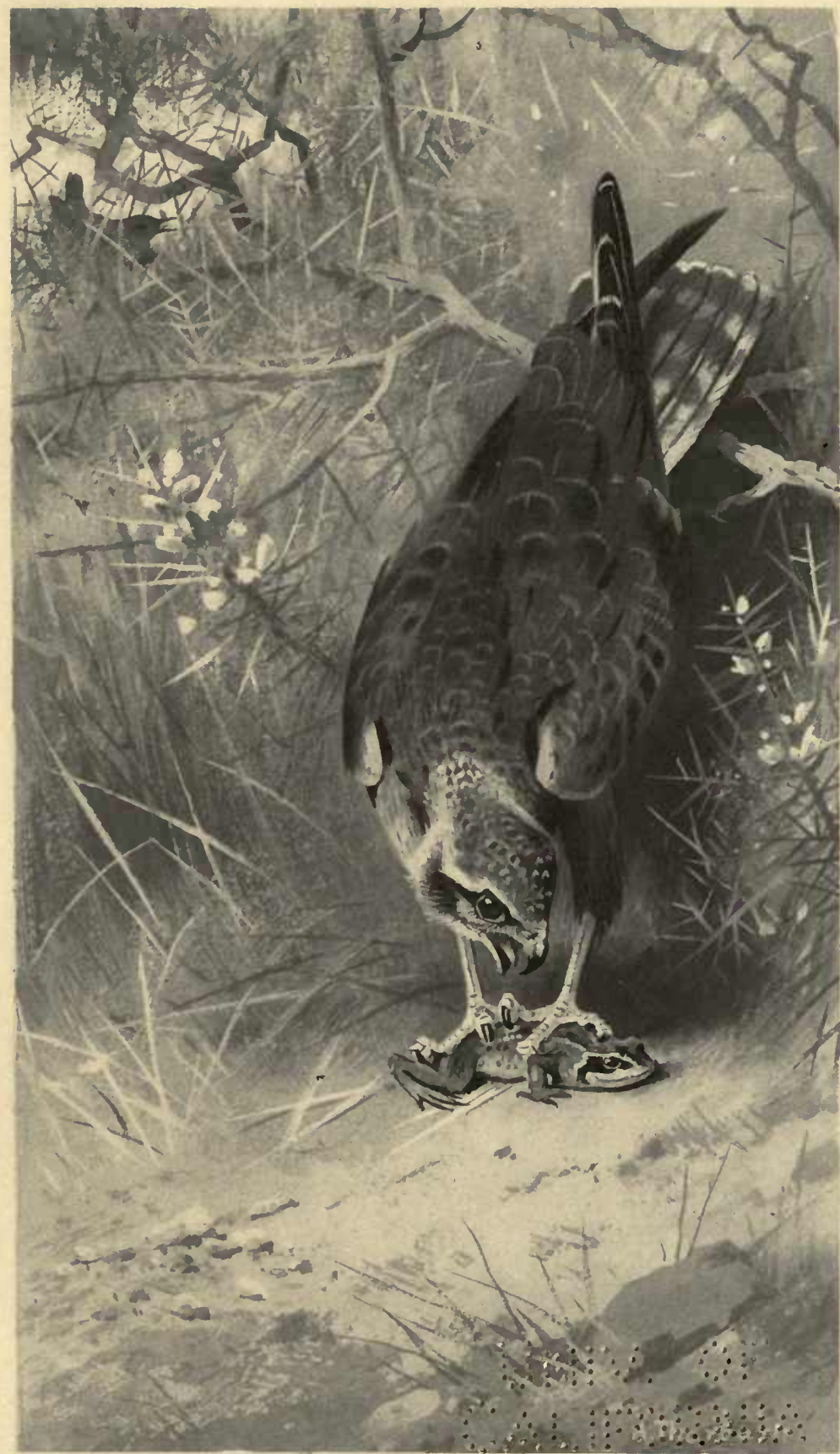

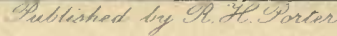

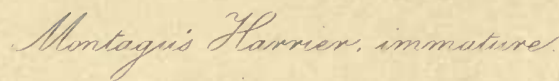




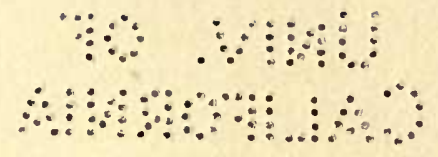


buoyant flight, and generally more red-brown colour of the females and immature birds. In hand, Mr. Howard Saunders has indicated a certain means of distinguishing this bird from the Hen-Harrier, by informing us that in the present species the outer web of the fifth primary has no notch or emargination, as it has in the case of the former bird. I may add that in every instance in my own experience, since I have been possessed of this information, I have found it to be fully verified.

In the south of Spain Montagu's Harrier is exceedingly common during the summer months, and nests, often in small colonies, in the great marshes, as also occasionally in growing corn. Black, or very dark brown, varieties of this bird are by no means uncommon; of this variety I have at this time of writing a fine specimen alive, received with two of the ordinary type of colour from a nest in central France. These Harriers, in my experience, certainly support captivity better than the Hen-Harrier, but require ample room to exercise their wings, as they are very restless and wild. The bird referred to at the commencement of this article is certainly a young one of the year.

\section{TAW NY OWL.}

Syrniun aluco.

This bird, commonly known in this county as the Brown Owl or Wood-Owl, is still, I am glad to say, pretty frequent with us, in spite of the unceasing persecution it encounters from gamekeepers. I cannot, indeed, entirely acquit the Brown Owl of an occasional bit of poaching, but I am convinced that 
such occurrences are exceptional, and, in defence of a very favourite bird, may refer my readers to the result of an examination of 210 péllets, composed of the indigestible portions of food thrown up by birds of this species, quoted in Yarrell's 'British Birds,' 4th ed. p. 148. I have also myself examined many pellets of the Tawny Owl, and, as far as game, strictly speaking, is concerned, with a similar result, though I have more than once detected the remains of young rabbits.

This Owl is probably pretty well known to those of my readers who live in the country. It loves old hollow trees and masses of ivy, but does not, so far as I know, frequent old buildings, barns, churches, \&c., as the Barn or White Owl so often does. With us at Lilford I have often remarked that the Tawny Owls become very noisy in the first frosty nights in September and October, and continue their nightly concerts with little intermission till the nestingseason. I have seldom heard their well-known "Whoo hoo" during the summer months except in the daytime, though the cry of the young birds is constantly to be heard after they leave the nest and begin to perch amongst the neighbouring branches.

This Owl is an early breeder; I have twice met with nests containing hard-set eggs in the last week of March, and several times seen strong-flying young Tawny Owls in April. I have no positive proof that this species breeds more than once in the same season, but I have had unfledged young birds brought to me at various times in May, June, July, and August, when some broods, at all events, had left the nests. With us this species generally chooses a hollow oak, elm, or ash for its establishment, and will use the 
same site year after year, although often robbed and disturbed, but I have also several times met with eggs and young birds of this Owl in old Crows' and Squirrels' nests, and am acquainted with more than one instance of nests in rabbit-burrows and on the bare ground.

T'he Tawny Owl is a very powerful bird for its size, and no doubt well capable of taking well-grown leverets and rabbits, but my own experience, as I have already stated, convinces me that such captures are exceptional, and that the food of these Owls consists for the most part of voles, rats, mice, with an occasional small bird, and a good many small fishes. I think the number of eggs is generally three, often four; I never met with or heard of more than the latter number. The young birds are easy to rear, become very tame, and, from their solemnity of expression and the grotesque attitudes which they assume, are amongst the most satisfactory inmates of an aviary.

\section{LONG-EARED OWL.}

\section{Asio otus.}

In our immediate neighbourhood this species, though well known as the Horned Owl, cannot be considered by any means common; in fact I cannot call to mind having met with it on more than three occasions, but I am informed by Mr. A. G. Elliot, of Stamford, in a letter dated February 29, 1876, that he had received "a great many from all parts," so that we may presume that it is not uncommon in that neighbourhood. I have been informed of several occurrences 
of this bird in various parts of Northamptonshire on good authority, and I was assured by one of Lord Westmorland's gamekeepers, in August 1872, that he had taken four young Long-eared Owls from a nest in a blackthorn thicket near Morehay Lawn during the summer of the previous year. This man was evidently well acquainted with the species, of

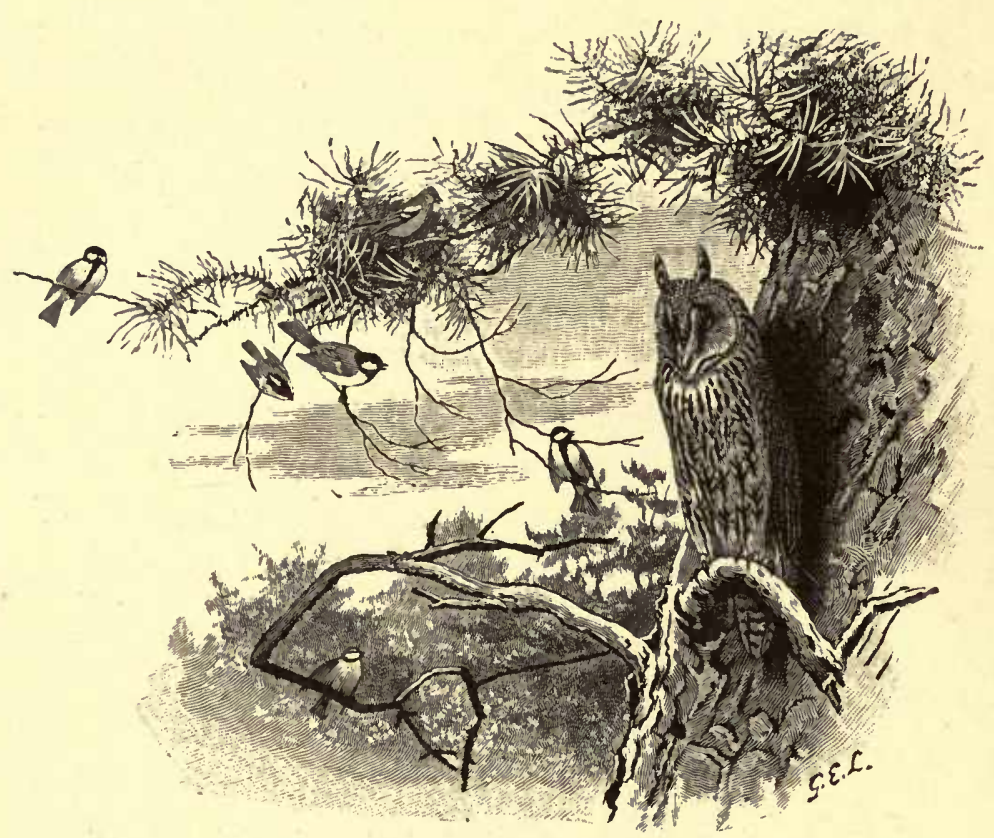

Iong-eared Owl mobbed by Iits.

which he gave a very accurate description. Since the above paragraph appeared in print our decoy man brought me a bird of this species alive that he found hanging, caught by the feet in the net over one of the "pipes," on October 20, 1891; I set this Owl at liberty, having in previous years liberated several nestlings sent to me from Norfolk, Suffolk, Surrey, 
and Hants, as soon as they could fly and provide for themselves. On April 25 a nest of Long-eared Owl containing five eggs was found in one of our plantatious at Lilford, but one of these eggs was cracked, as I believe, by a Squirrel, and the nest was evidently deserted when first discovered. Although both the parent birds remained in the immediate neighbourhood for a considerable time, I could not hear of their attempting to breed again.

In many parts of England, especially those in which there are large extents of fir-woods, this Owl is very abundant, and, according to Yarrell and other authors, its numbers are increased in the eastern counties by an autumnal migration. We have more than once, when shooting in West Norfolk and Suffolk, come upon a party of ten or more of these Owls collected in an old Scotch fir or scattered in a young plantation of spruce or larch; they disperse on being disturbed, and, if marked into a thick tree, may be very closely approached and watched. I would never lift my gun at an Owl of any species in this country, but I am sorry to say that on occasions such as I have just mentioned my companions have seldom been of my way of thinking, and many of these useful and beautiful birds have fallen victims without any reason whatever.

From my own observation I am inclined to think that the Long-eared Owl prefers small birds to quadrupeds as food, though it no doubt destroys many field-mice and voles. In the absence of firwoods this Owl will take up its abode in thick masses of evergreen shrubs; and in the island of Corfu, where it is not uncommon, is generally met with in the thickest coverts of arbutus and myrtle. With a 
few exceptions, the nests of this species which I have seen were apparently superstructures on a foundation of old nests of the Wood-Pigeon, and in one instance certainly of the Jay; but I believe that it has a special predilection for Magpies' and Squirreis' nests. I do not know that hollow trees are ever used by the long-eared Owl for nesting purposes, or, indeed, as an abode at any time.

In common with most of the family, this Owl is an early breeder; I have found the eggs in the north of Ireland in the first week of March; the usual number is, I think, four. The young birds remain a long time in and about the nest, and keep up an incessant plaintive and monotonous cre. The pairing-cry of the old birds is a prolonged and most disagreeable scream, but is very seldom heard, and certainly never to be forgotten. This species thrives fairly well in confinement.

\section{SHORT-EARED OWL.}

Asio accipitrinus.

With us this Owl is an irregular autumnal visitor, gemerally putting in an appearance about the second or third week of October, at which time one or two may often be found on the rough fields near Clapton, known as Wigsthorpe Wolds, which I have before mentioned when treating of the Hen-Harrier. I have also scen it and been informed of its occurrence in many other parts of Northamptonshire and Hunting donshire.

The habits of this species differ widely from those of any oiher British Owl, as it very rarely frequents 


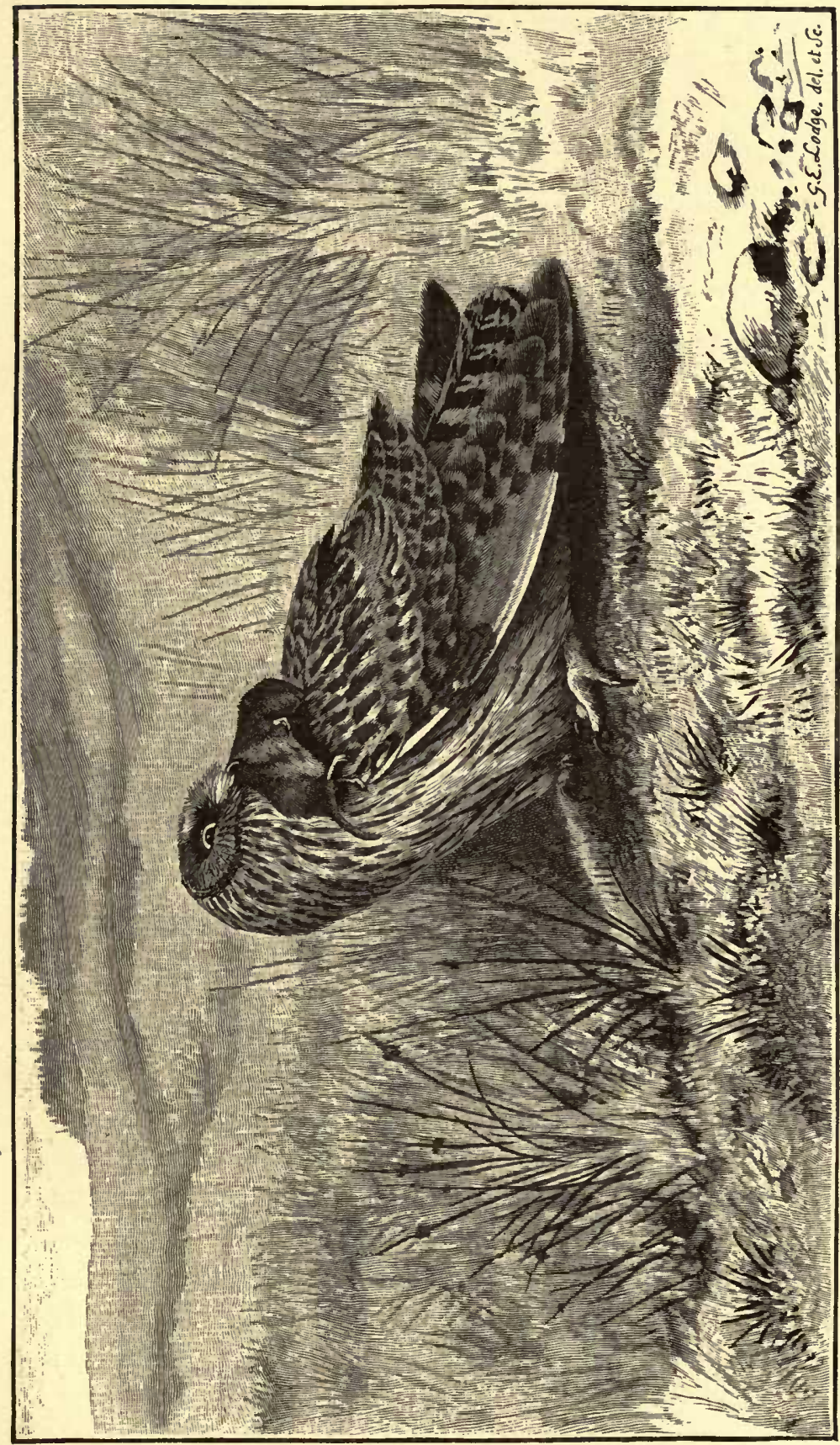


woods or even plantations of any height, and never haunts old buildings, but must be sought for in open grassy fields, commons, low furze-brakes, sedgy marshes, and is not uncommonly met with among turnips. In the fens the Short-eared Owl is sometimes found, at the time of year above mentioned, in flocks of twenty or thirty together, probably just arrived on their southward migration, but in this county I never met with more than two at the same time. I imagine that this bird is less incommoded by the sunlight than any of our other Owls, as when disturbed it sometimes mounts to a considerable height and flies steadily off, without the wavering undecided action of the Tawny and Barn Owls. I have more than once seen this $O w l$, evidently seeking its prey, in broad daylight, when its mode of operation precisely resembled that of the Harriers, to which family, indeed, in many of its habits it closely approaches.

'The Short-eared Owl has a very wide geographical distribution, extending, according to Yarrell, pretty nearly all over the continents of Europe and Asia, many parts of Africa, and America from Greenland to the Straits of Magellan. I have myself received a living specimen from Chili, in which I could detect no difference from our typical European species.

Of the nesting and breeding-habits of this bird I know absolutely nothing from personal observation, but it formerly nested not uncommonly in the fens of Cambridgeshire, and still does so occasionally on the moors of northern England and Scotland. The nest, according to various authors, is always on the ground, and generally is nothing more than a slight cavity scraped by the birds, without any lining. It appears 
from Sir William Jardine's account, quoted at p. 164, vol. i. Yarrell's 'British Birds' (4th ed.), that this Owl is a very late breeder, as the young birds are barely able to fly by August 12th. The eggs are from three to five. I have kept a few of these birds' in confinement, but, with one exception, never succeeded in really taming them. The exception was a most delightful bird, which would follow me about, come to whistle, and sit upon and feed from my hand, but did not live long. The stomachs of several of this species which I have examined contained the indistinguishable remains of small birds and fishes, of which last article of diet all the Owls of my acquaintance are very fond.

\section{SCOPS OWL.}

Scops giu.

This is a rare and irregular visitor to our Islands, and $I$ admit it to my list of Northamptonshire birds solely on the following evidence. In a list of birds in the neighbourhood of Stamford, kindly sent to me by Mr. A. G. Elliot, of that town, in February 1876, he states:- "One little Owl I saw fresh killed when a boy, quite thirty years ago, by H. Burbidge at the Dog-kennels or Life, close to Iuddington; and it was stuffed by John Taylor, of Barrowden; I think it was Strix scops, having noticed it for years afterwards, but now lost sight of it." Mr. Elliot came to see me at Lilford a few days after I received his list above mentioned, and on my showing him the skins of various small Owls, immediately selected one of 
the present species, and declared that "this is the bird."

I may here mention that I have been positively assured by several friends of the former existence of a very minute "Horned" Owl in Wakerley Wood, a large covert belonging to Lord Exeter, not far from Barrowden. The concurrent testimony of my various informants was to the effect that a few of these little birds were generally to be seen when the wood was shot through, and that they were about the size of a Missel-Thrush. I never could discover that any one had shot one, and the only time that I lad the pleasure of shooting in Wakerley Wood I found the gamekeepers ignored the little Owls altogether. 'The Scops Owl is a regular and, in some parts, a very abundant summer migrant to Southern Europe; but has occurred in England and Ireland at almost all seasons of the year. The probability of its beirg met with in the covert shooting-season in any ore particular spot in this country is but small, but my informants were so positive as to size, and the fact of the birds being "licrncd" Owls, that I can but tell the story as it was told many times to me. I should at once have considered the bird to be the Little Owl (Athene noctua), also a rare visitor to this country, though it ranges commonly further northwards on the continent of Europe than the Scops, but the Little Owl is not "l.orned," and I must therefore leave my readers to draw their own inferences.

I have met with the Scops Owl in great abundance in various parts of Spain and in the Ionian Islands, in which countries it arrives from the south in April, for the most part leaving again in Norember, though 
a few scattered individuals remain in Andalucia throughout the winter months. In the avenues of the Alamedas, or public walks of Seville, this little Owl is especially common, and in the spring its melancholy call of "Keeyoo" may be heard all night, and often in the daytime, in those places. 'This species has but little fear of man, and I have several times watched one from a few yards distance, as it sat generally tightly drawn up against a tree-trunk, sometimes with one eye closed and the other slowly winking with an irresistibly comic effect. 'Though this Owl, in common with almost all others, prefers the shade of thick foliage for its diurnal retreat, yet it seems perfectly indifferent even to the full power of the summer sun of Andalucia, and flies with a quick and direct undulating flight from tree to tree when disturbed in the daytime. The old olive-groves of Corfu are favourite haunts of this Owl, and in their hollow trunks the nest is often to be found, formed of a very few sticks and grasses, and containing from three to five eggs. In Spain, though the olive is extremely abundant, the Scops appears to prefer hollow elms, poplars, and willows; the cork-tree is also a favourite resort. I believe that the food of this Owl consists almost entirely of varicus insects, beetles, and large moths. Be their diet what it may, they are brought into the market of Valetta, Malta, by dozens in April and May at the period of the remal migration, and find a ready sale as food, being often served up for dinner at the regimental messes under various names, though not, so far as I know, the true one. My own experience is that the flesh is very good.

In captivity these little birds become very tame, 
and are most amusing. One which I kept for a long time at Corfu preferred the Humming-bird moth, which abounded there, to any other food I could give him. I think that these Owls devour a greater weight of food for their size than any bird with which I am acquainted.

\section{BAR N OWL.}

\section{Strix flammea.}

This bird, perhaps better known in this country as White or Screech-Owl, is common throughout Northamptonshire, and in this immediate neighbourhood may be called abundant. Few summer evenings pass without two or more of these birds being on view hunting over the meadows close to this house, and many more are to be heard than seen. I think that in most parts of England gamekeepers are beginning to find out that in killing the Barn Owl they are murdering a most efficient ally in the destruction of the worst, because the most numerous, enemies to game in this country, $i$. e. the Brown Rat, to say nothing of those little pests, the various species of mice and voles.

The present species, as is probably well known to my readers, selects a hollow tree, a hole or crevice in old buildings, or a dense dark fir tree as its usual resort, where, during the daytime, it remains apparently fast asleep till dusk, when it sallies forth in quest of food. I have several times climbed up to various holes in old trees in this neighbourhood just to see if my friends were at home, and often watched them for some time without disturbing, or apparently 
AND NEIGHBOURHOOD.

61

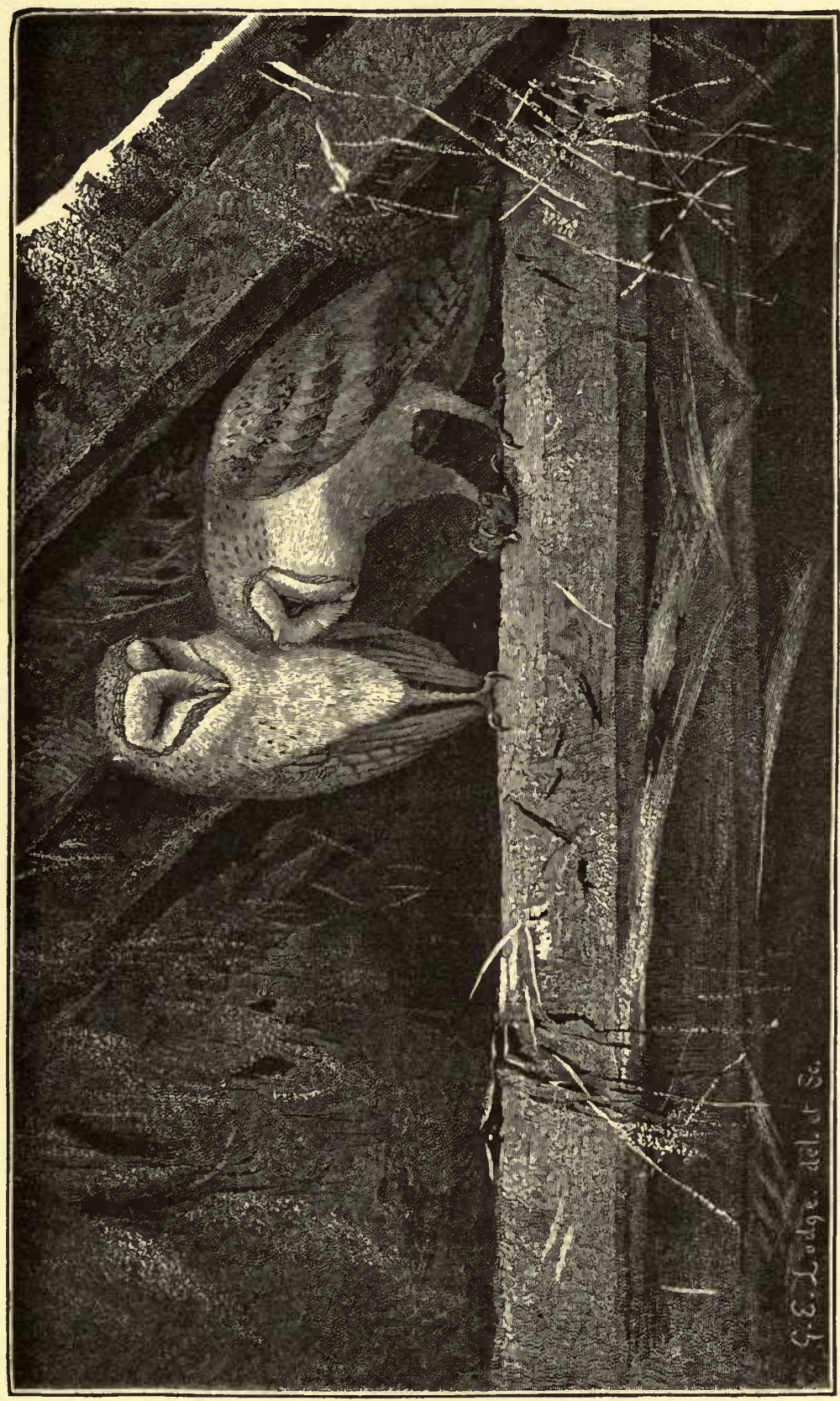

0
0
0
0
0 
eren waking them, but occasionally have been detected, when the Owls (for there were often more than one) have made no attempt at flight, but merely attenuating themselves to their narrowest dimensions, swayed their bodies slowly to and fro, with many loud snaps of drowsy defiance.

Many years ago I was staying at the rectory at Tichmarsh; a pair of Barn Owls had a nest full of young in the celebrated cedar in the rectory garden, and one fine evening the old birds came bringing food to their young seventeen times in half an hour by the clock; there was a rickyard within thirty yards of the nest, and this was the Owl's special hunting-ground, as I repeatedly observed: mice were comparatively scarce, probably because rats swarmed, and the pellets found under the nest were in this instance composed almost entirely of the remains of the latter vermin. In other cases, besides the abovementioned animals, I have found many skulls of Sparrows and Finches, which I presume are caught in the ricks, one or two of Bats, and fragments of various fishes. I have often been told by gamekeepers that they often saw Barn Owls hovering about their pheasant-coops, but have always answered that if the young pheasants are outside their coops at the time the Owl is flying, the keeper is to blame, and that the Owl's visit is for mice or rats, and not for game; indeed I do not recollect one authentic case of poaching to have been proved against the Barn Owl hereabouts. I do not know that in Northamptonshire, or at all events in this neighbourhood, the superstitions formerly so prevalent with regard to Owls in general, and this species in particular, ever had much hold on the people, but, to my 
personal knowledge, in Wales, not very many years ago, the screech of the Barn Owl was considered a certain warning of imminent death, and in another part of England on my asking a gamekeeper why he killed the Owls, he assured me that though he could not say for certain that they killed game, yet they were unlucky and no good to any one. I tried to convince him that their unluckiness was the fact of his destroying them, and that they did immense good to many people, but I feel sure that I only wasted my eloquence upon him, with the result of persuading him that I was a harmless lunatic. One of the most extraordinary accusations which I ever heard brought against the Barn Owl was that of attacking sheep as they lie asleep in the fields, and tearing their ears and faces. In Spain this species and the Scops Owl are accused of drinking the oil from the lamps kept burning in the churches and chapels, and I have heard of a similar story with regard to a species of the family in Mexico.

The Barn Owl is reported as common in most parts of Europe except the most northern. I have met with it in nearly all the Mediterranean countries which I have visited. The Moors and Jews of Morocco have some peculiar and curious superstitions with regard to this bird, for an account of which I must refer any of my readers who may be interested in such subjects to the 'Ornithology of the Straits of Gibraltar,' by Lieut.-Colonel L. H. Irbץ. The Barn Owl, I think, makes very little or no nest, but with us it often happens that the hole in a hollow tree, selected by the old birds for rearing their brood, is previously occupied by Jackdaws, which birds, in several instances that have come under my notice, 
have been driven away by the Owls, who take possession of the Daw's nest and commence laying therein without altering its form or substance. I have found now and then an egg or two of the Jackdaw with those of the Owl. 'This species begins to lay in April, and I firmly believe that the hen bird begins to sit as soon as she has laid her first egg, as I have often seen five or six young Owls in the same nest varying in size and plumage from a fully fledged bird well able to fly, to a little puff of white down, certainly not more than a week old. In a recess in Barnwell Castle, which must, I think, at some time or other, have served as a fireplace, I once found ten Barn Owls huddled up together, apparently of all ages, as they certainly were of all sizes, but I do not think that in this gathering there was more than one old bird. I quite agree with Yarrell as to a second and third laying taking place before the first family leaves the nest, and the consequent hatching of the later eggs by the elder birds. In a very fine ancient walnut-tree close to Pilton Rectory, and within a few minutes' walk of this house, a pair or two of Barn Owls have been established for many years; and as their establishments are generally situated at the extreme ends of the cavities in the large branches of the tree, they are almost impossible of access and safe from boys. 1 have known seven species of birds to be rearing their broods at the same time in this tree, viz. Barn Owl, Spotted Flycatcher, 'Tree-creeper, Starling, 'Tree-Sparrow, Jackdaw, and Stock-Iove. I have more than once seen a Barn Owl hunting over a meadow in broad daylight, though not in sunshine, but I think that this species is more dazzled by the sun than any other Owl with which I am 
acquainted, and in our park, where there are many hollow trees frequented by the Owls, I have often remarked that when disturbed in the daytime they blunder into the first shady tree that offers itself, apparently not knowing the way from one haunt to the next. The digestion of all the Owls, and of this species in particular, is marvellously rapid: I have seen a young half-grown Barn Owl take down nine full-grown mice one after another till the tail of the ninth stuck out of his mouth, and in three hours' time the young "gourmand" was crying, or rather snoring, for more food, and would, I have little doubt, have disposed of nine more mice had I had them to give; he was, at all events, not satisfied with four.

There is a prevalent idea that Owls kill but will not eat Shrews; but I can positively assert the contrary with regard to this species, at all events when in confinement. It is certainly true that the little animals above named are often to be found dead without any apparent external injury, and the few of those so found by me, which I have examined closely, appeared, to my unskilled eyes, to be equally free from any morbid condition of the vital organs, though generally very thin. I cannot offer any solution of this question, except possibly a failure of some special food, and the physical inability of the:Shrew to adapt itself to a new diet, but this of course is merely theory, and would be very difficult to prove. I have often seen cats bring in Shrews, and after playing with them for some time leave them, and I cannot recollect any instance of a dog eating one, but the Barn Owl and Kestrel certainly will do so, and though I cannot positively recall the particulars, I feel sure 
that other birds of prey in my possession have not rejected these curious little insectivora. In conclusion, I would earnestly beg all or any of my readers who may have it in their power to protect and encourage the Barn Owl in all ways, and to rest assured that they will find him, though undoubtedly of a retiring disposition, a most quaint, interesting, and valuable friend. His voice is not pleasant, but we cannot expect everything even in an Owl.

\section{LITTLE OWL.}

Athene noctua.

I am glad to say that I have, since the preceding notes were published, succeeded in establishing the Little Owl as a resident Northamptonshire bird, and consider that this species is entitled to a separate number and article, as fully as are the Pheasant and Red-legged Partridge. I have for a considerable number of years annually purchased a number of these Owls in the London market, and as the majority are too young to fly when first received, I have had them placed together in large box-cages in quiet places about our grounds at Lilford, and left the doors of the cages open, taking care that an ample supply of food is provided once during the day for the Owls. I regret that $I$ have not kept notes as to when I first adopted this practice, but for several years, beyond the fact that we occasionally saw and frequently heard of one or more of the Little Owls in the neighbourhood, nothing of importance came of the experiment, so far as I am aware, till 1889, when one of our gamekeepers, on April 23, found a Little 


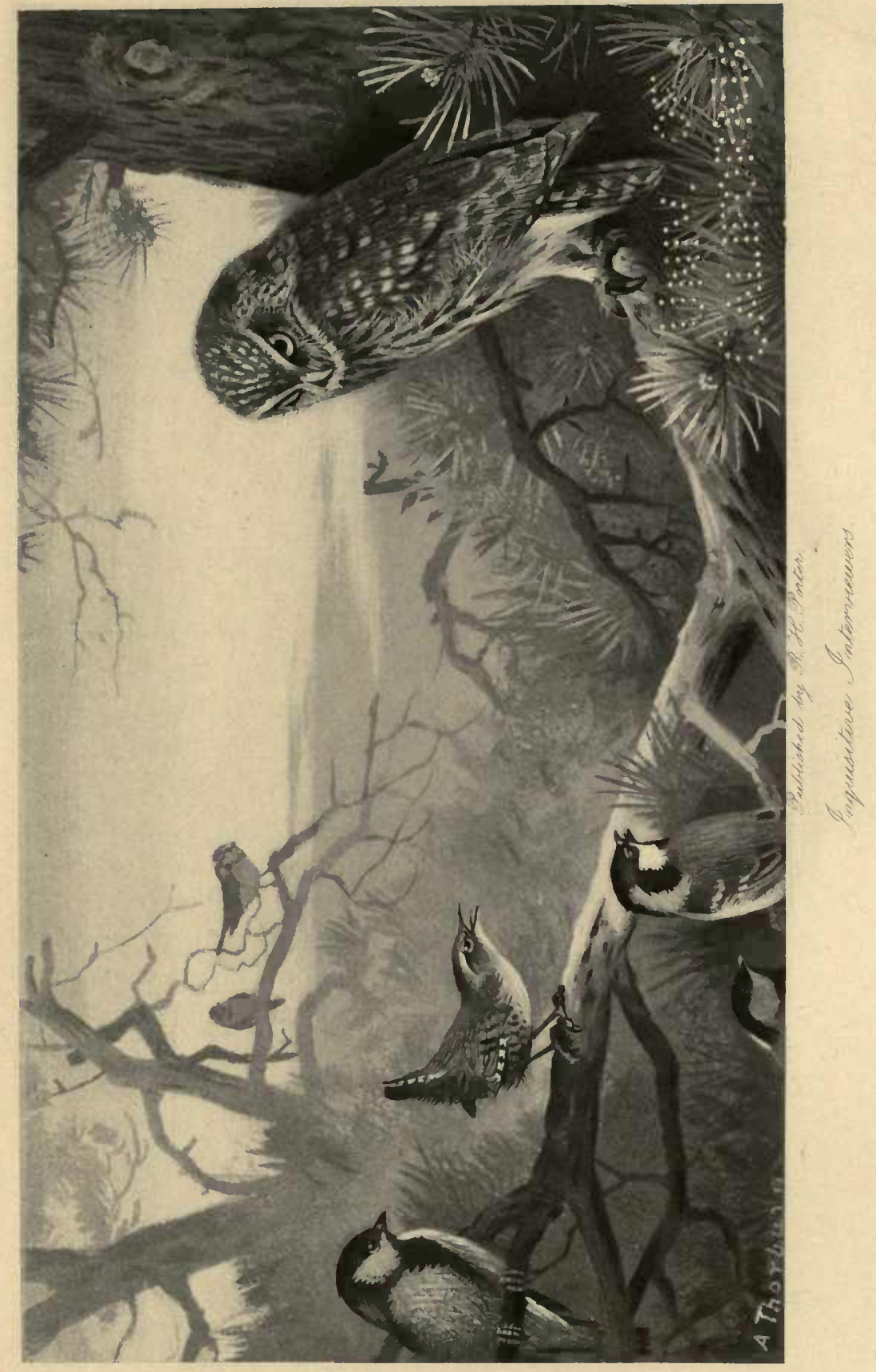



Owl sitting in a hollow bough of an old ash-tree in the deer-park at Lilford; she would not move, but he lifted her, and found that she was sitting upon a single egg, to which she added three, and brought off four young birds in the second week of June. One, if not two, other broods were reared in our near neighbourhood in 1889. In 1890 a nest of Little Owl containing six eggs was found in another hollow ash-tree in the park on April 25: all these eggs were hatched and the young reared to maturity. On October 15 of the last-named year I received a Little Owl alive and uninjured that had been discovered by a pointer-dog a few days before in a rabbit-burrow in the park at Deene. I was informed that a birdstuffer at Stamford had one of the present species (which he called a "Dutch Owl") in his shop, in February 1891, sent to him from Normanton, Rutland. A "nestful" of young was discovered early in July 1891 by a gamekeeper in a hollow elm on the Wadenhoe Manor, and was left unmolested. During the first three months of 1892 I received very frequent reports of Little Owls seen from many different places in the neighbourhood of Lilford, and on April 19 a nest containing four eggs was found on Wadenhoe, within a short distance of the nesting-place of 1891 , in a cavity of an ash-pollard. Towards the end of June the tenant of the farm upon which this pollard stands, unaware of the Owl's nest, passed within a few feet of it, and was furiously attacked from behind by one of the parent birds, which knocked his hat over his eyes and clawed the back of his head severely. The only other record of this species that I find in my note-book for 1892 is to the effect that Mr. A. Thorburn saw near our aviary, and made a charming 
sketch of, a Little Owl mobbed by Robins, a Wren, Great Tits, Blue Tits, Marsh-Tits, Chaffinches, and a Blackbird, on November 11.

In 1893 a nest containing several young was found in the park at Lilford, on May 13. I had authentic reports of one or two other broods on Wadenhoe, and another near Lyveden; and on August 15 the victim of the above-mentioned attack informed me that, some six weeks before, he had again been violently assailed by a Little Owl in the churchyard at Wadenhoe. I have some reason to believe that there was a brood of these Owls in Wadenhoe church-tower. On December 22 I was pleased to hear from a lady living at Stoke Doyle that several of these birds had made a settlement in some old trees near her garden. With the exception of the bird killed at Normanton, and another at Elton, I have not heard of the death, by human agency, of any Little $\mathrm{O} w \mathrm{ws}$ in our district, although a few have been picked up dead from natural causes. I generally receive my consignments of these birds during June; very few come for food to the feeding-boards after the first week in August, and we leave off feeding about the middle of that month. These Owls delight in taking the sun, and are active during the hours of daylight. They are infinitely useful in the destruction of voles, mice, sparrows, and insects of many kinds, and have a decided liking for earth-worms. In Spain the Little Owl is very common and resident: from my own experience in that country I am disposed to think that it prefers the crannies of old buildings for nesting-purposes to any other sites, but it nevertheless frequently takes possession of hollow trees, and I have more than once found it breeding on the ground amongst the roots of 
old cork- and wild olive-trees. It is not unusual to see a Little Owl perched on a tall thistle in broad daylight in the great plains of Spain, and it is still more commonly to be found in summer in the dry but water-worn " barrancos" or ravines that intersect these plains.

This species is more or less common throughout Europe to the south of the Baltic, and is very numerous in Holland, from which country all my birds were originally obtained. In Italy the bird-catchers use the Little Owl to attract small birds to their limed sticks. In captivity this $\mathrm{Owl}$ is most amusing from its grotesque antics and its extraordinary tameness. No better destroyer of cockroaches can be found than one of these birds at liberty in a room infested by these loathsome pests.

\section{GREAT GREY SHRIKE.}

Lanius excubitor.

The only notice of the occurrence of this bird in our county which I can find is at p. 424 of Morton's ' Natural History of Northamptonshire,' before quoted. He says:- "The Lanius cinereus major, the Greater Ash-coloured Shrieke or Butcher Bird: a very uncommon Bird, except it be in the Mountainous Parts of the North; and yet tho' a mountainous Bird, it breeds sometimes in Northamptonshire, and particularly in Whittlewood Forest, where 'tis called the Night-Jarr. Now and then one of them is seen at Winnick, in Ellinton Grounds, and in Stoke Albany Park particularly in the month of August."

'This is sufficiently perplexing, on account of the 
information that the bird in question is called "NightJarr;" but as the very next species mentioned is the "Fern-Owl, Churn-Owl, or Goat Sucker," I cannot help thinking that the "Night-Jarr," and probably the mention of its breeding in Northamptonshire, have slipped into the wrong place. It has occurred to me even that the passages may have been transposed, and that the above quoted may refer to the Fern-Owl, and the following (on the same page and immediately below it), though headed "Fern-Owl, Churn-Owl, or Goat Sucker," really have reference to the "Greater Ash-coloured Shrike:"-_This also is a Mountainous Bird frequenting the Rocky Woods of Yorkshire, Derbyshire, \&c. Yet was shot by Mr. Eyres of Dean in our Oxenden Closes in September 1708."

It is, however, I think, pretty clear that the Great Grey Shrike had really occurred in our county to the knowledge of the worthy old rector of Oxenden, who was a keen collector of birds, of which he tells us he had the skins or cases of above "one hundred sorts which were killed in this country" (quore county?). Yarrell ('British Birds,' vol. i. p. 199, 4th ed.) says that this bird has never been ascertained to breed in this country; and such an occurrence has most certainly never come to my knowledge, all the statements to the contrary of which I have heard having collapsed on examination.

The Great Ash-coloured Shrike generally visits this country in the winter, and its breeding in Whittlewood Forest "sometimes" is, though of course not impossible, extremely improbable. I shall prove further on that Morton did not confound the present species with the Red-backed Shrike, Lanius collurio, 
as has often happened since his day, and altogether I think that those of my readers who are ornithologists will agree with me that our present species is much more likely to have been shot once in Oxenden Closes than to have bred more than once in Whittlewood Forest, to be seen now and then in various other places in the county, and to be called "Night-Jarr," whereas all the above occurrences are more than probable with regard to the bird which properly bears this latter designation, though we moderns consider one final " $r$ " sufficient. We will, at all events, retain the Great Grey Shrike on our list, and leave the locality to the judgment and taste of our readers upon the above evidence. In a letter from Mr. W. Dunbar, a well-known ornithologist, to Mr. G. Edmonds, of Oundle, kindly forwarded to me by the latter-named gentleman, he mentions the Great Grey Shrike as having been met with near Braunstone, and I was told many years ago, on good authority, of an occurrence of this bird near Northampton. A specimen was shot by one Russell in Holme Fen, probably in 1824 , as I am informed by Mr. John Heathcote, of Connington Castle. We cannot claim this last as a Northamptonshire bird, but I mention it, as a flight of some eight or ten miles would have brought it over our borders, and in treating of zoology it is irksome to be strictly bound by political divisions.

'This Shrike is common in Holland, Belginm, parts of France, and in Switzerland, in which last country I have often met with it. It is rather a shy and wary bird, generally selecting a tree-top or high bare bough in a hedge as a look-out station, and making off on the approach of danger with a rapid undulating flight. In the summer months the food of this bird seems to 
consist chiefly of large beetles, butterflies, moths, and grasshoppers, but it is also very destructive to small birds ; in Switzerland, in the winter, I noticed that the various species of 'litmouse are a favourite prey. In common with all the Shrikes of my acquaintance, this species generally fixes its dead prey upon a strong thorn, or in a forked twig, and pulls it to pieces, but I have also seen it stand upon its victim and devour it after the fashion of the true Raptores. The nest is

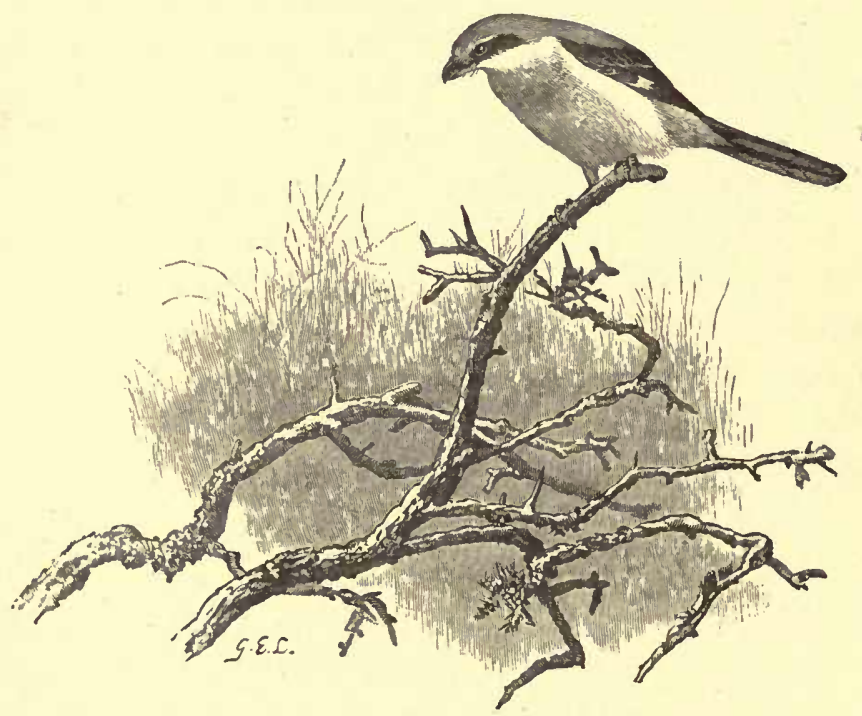

Great Grey Shrilze.

large and rather loosely built of twigs and moss, with a lining of wool; it is generally placed in a fork of a bough at some height from the ground, fruit-trees, such as apple, almond, pear, and plum, being often selected. 'The number of eggs I should say averages five, but I have known of several nests with six. When a pair of these birds have chosen a nestinglocality, they will not allow another of their own 
species anywhere in sight, and pursue magpies, crows, jays, \&c. which may intrude on their domain with great impetuosity and loud outcries; when the young are hatched the old birds will occasionally even attack any person approaching their nest, and seem to lose all their natural timidity. The usual note of the Great Grey Shrike is a curious indescribable croak or scream; but it occasionally breaks out into what may be called a song, a sort of jumble of the notes of many birds. I have at this moment in the room as I write a caged Jay, which sometimes reminds me very much in his discourse of these outbreaks of the Shrike, but the notes of the latter are more subdued, and, indeed, only audible at a short distance. For a short account of the services of this Shrike to the Falconer or Falcon-catcher in Holland I refer my readers to Yarrell's 'British Birds,' vol.i. p. 201, and for a more detailed one to Messrs. Freeman and Salvin's 'Falconry' \&c. before referred to. I have found this species difficult to keep long in confinement, but all those I have so kept have been wildcaught birds.

Since the above article was published several occurrences of the Great Grey Shrike in our county have come to my knowledge; as I have recorded these at various times in the 'Zoologist,' I only append a few of the details therein related with regard to them :Mr. W. Tomalin, of Northampton, informed me that a specimen of this Shrike was killed about the middle of November 1880 in Midsummer Meadow, close to that town. About the end of December of the year just named I received a fine young bird of this species alive, that had been taken, by means of bird-lime, near Glendon, on November 19. I kept this bird alive 
for some months. The late Mr. G. Hunt shot a young female Grey Shrike near Tichmarsh Mill on November 1, 1881, and sent it to me. Colonel L. H. Irby and my son found one of these birds dead near Aldwincle on November 20, 1886. My falconer reported that whilst he was employed in an attempt to catch Falcons (in the fashion alluded to above), on November 11, 1889, his sentinel Shrike was visited by a wild bird of this species, which, after helping itself to a little of the said sentinel's food, remained in the neighbourhood of the hawk-hut for about an hour. I heard from Mr. W. Tomalin of the capture of a Great Grey Shrike near Northampton about three weeks before December 2, 1889, and I have some four or five other records from various parts of the county.

\section{RED-BACKED SHRIKE.}

\section{Lanius collurio.}

Twenty years ago I should have been justified in describing this bird (better known, throughout those parts of England in which it is found, by the name of "Butcher-bird") as exceedingly rare in our neighbourhood, indeed till 1860 I never even heard of its occurrence near Lilford; since that time I have constantly been told of a pair or two having been met with in the early summer, at which time I am unfortunately almost always away from home, and now the Butcher-bird is, though not very abundant, a regular summer visitor, and breeds annually in our district. Morton, in his 'Natural History of Northamptonshire,' corrects an error of Willughby, who had represented the female of this bird as a 


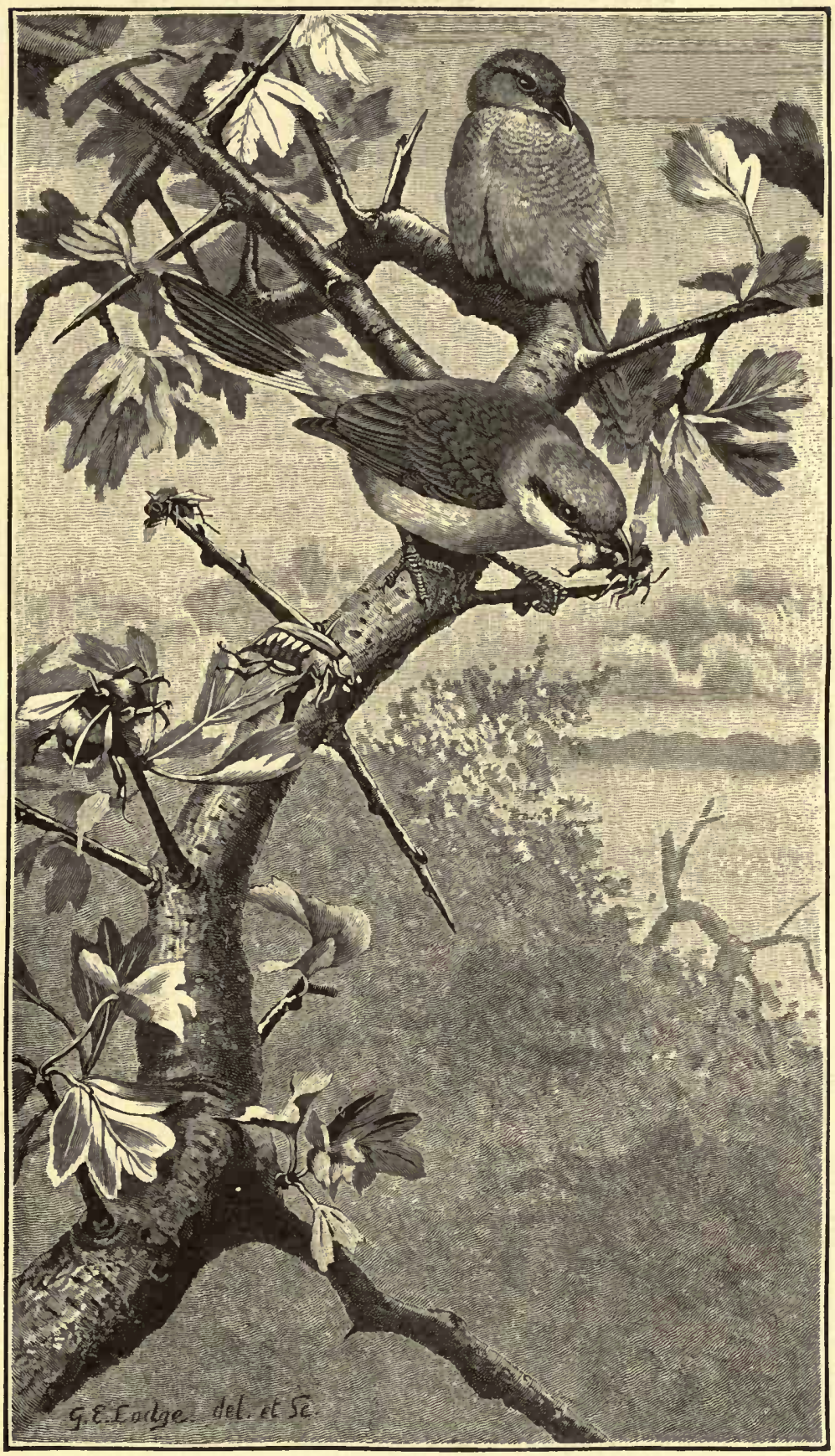

Red-backed Shrikes and Iarder. 
distinct species in his 'Ornithology,' p. 255. Morton gives recognizable "draughts" of both sexes, and after telling how he had discovered the error made by Willughby by observing the birds in pairingtime, and by dissection, says:- "Both the male and female of this species have been shot upon the bushes, in a bushy common south-west of Braybrook, in the month of May. But 'tis a very uncommon bird with us." He calls the bird "The Lesser Ash-coloured Butcher-bird." I have many notices of the occurrence of this bird in various parts of the county, but no records, except from our own district, as to whether it has become more abundant of late years. It is, I think, more common on light soils than on our stiff clays, and therefore probably better known in the south of Northamptonshire than in our district.

In many parts of England and in North Wales I have found the Red-backed Shrike in some abundance, especially, in my school-days, in the neighbourhood of Harrow-on-the-Hill, where we often used to find two or three nests on a summer's afternoon in the thick and ragged fences which divided the great grass-fields of that district. I understand that the bird is now uncommon thereabouts, but it is generally a well-known species in most of the southern and some of the midland counties. This Shrike generally arrives, or at all events used to arrive about Harrow, in the first week of May. The male is a handsome and conspicuous bird, and his curious chirping croak soon betrays his arrival. I have watched the manner of feeding of this species very minutely and very often: the male bird selects the topmost shoot of a thick thorn bush, or a projecting bare bough in a fence, whence he constantly darts 
down into the grass upon a beetle, grasshopper, or other insect, every now and then varying this performance with an aerial excursion after a passing cockchafer, dragonfly, butterfly, or bee. In the case of a large or tough insect the bird generally fixes it on a thorn, and deliberately pulls it to pieces and devours it therefrom, but grasshoppers, small moths, bees, \&c. are for the most part disposed of hawkfashion, $i . e$. held by the feet of the bird, and torn up and eaten from the perch. As far as I could observe, this method is not adopted by the female Shrike, who seems to roam about more than the male, and to feed a good deal upon the insects caught and impaled by her mate, though of course she does a good deal upon her own account also till she begins to sit, when I believe that she is entirely supported by the male. I have never actually seen one of these Shrikes take a bird, but they often do so; and I have more than once found the remains of small birds, in one instance a young Whitethruat (Curruca cinerea), impaled in the Shrike's larder. With the above exception and one large earthworm, I never found anything but insects in these thorny depositories; but it is stated on good authority that this species also takes mice and shrews. Unlike the Great Grey Shrike, the present bird seems to have very little fear of man at any time, and I have often sat for a considerable time within twenty yards and in full view of a male Shrike, who pursued his avocations, as above described, without troubling himself in any way about my observation. The nest is large, built of strong grass-stalks and moss, generally, but not always, lined with some wool or hair, often with no lining but a few fine roots or twigs, and situated in the thickest part of a bramble- 
grown fence, or dense thorn or bramble bush; one nest I found in a tall furze bush. The eggs are generally five, and vary a good deal in colour, but the ground-colour is generally either a greenish white or a creamy pink with a zone near the thick end, in the former case of brown, and in the latter of red and lilac blotches.

\section{WOODCHAT.}

Lanius rutilus.

This Shrike, though exceedingly common in summer in many parts of Southern Europe, and not by any means rare in Germany and Holland, is a scarce bird in England; and the only notice I have of it as a visitor to Northamptonshire is in a letter from Mr. A. G. Elliot, of Stamford, who says, "Woodchat, Lanius rufus: I saw one in Gore Piece close to Duddington in the spring of 1869." Mr. Elliot is well acquainted with our British birds, and is not, I think, likely to have made a mistake about such a distinctly marked and conspicuous bird as the Woodchat. Yarrell says that most of the occurrences of this species in England have been in the southern counties, and records two instances of its breeding in the Isle of Wight. In Southern Spain, where the Woodchat is a very common summer visitor, it is to be met with in all sorts of localities - the outskirts of woods, olive-groves, gardens, and occasionally the great open treeless plains, where the tall thistles alone offer it a perch or look-out station. In general habits it much resembles the Red-backed Shrike, but 


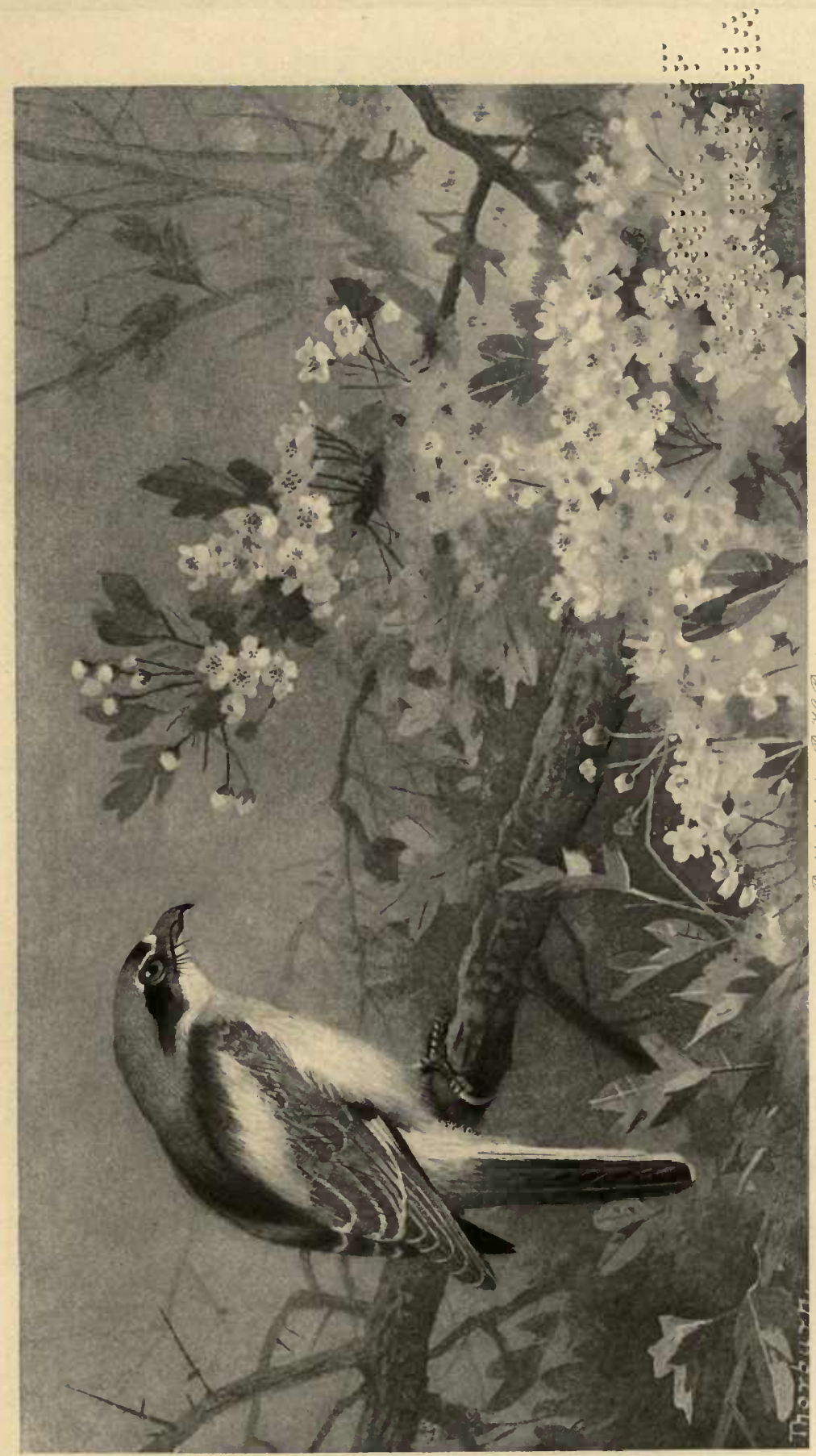




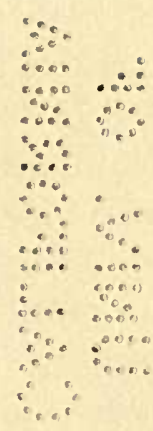


so far as I know does not attack small birds, which show no fear of it as they do of the former bird. The nest is always placed in a tree, composed of strong bents and cotton-grass externally, with a lining of fine grasses and moss. The eggs somewhat resemble those of the Red-backed Shrike; but I have never met with the red variety which is not uncommon in that species. The Woodchat is a very familiar and fearless bird, and seems often to prefer the vicinity of human habitations for its nest. In all its habits this Shrike seems to me to approach closely to the Flycatchers.

In the 'Field' of January 13, 1883, there appeared a communication from Mr. Elliot, above mentioned, to the effect that a Woodchat had been picked up dead near Stamford. I at once wrote to him on the subject, and received the following reply:- "The Woodchat noted in 'The Field' was picked up dead on the 9 th inst.; it is a female, and in fair condition, the plumage is slightly soiled. It appears to have been on the fallow land some time, and had been dead at least two days before I received it; one side of the head was slightly decomposed; it was in very poor condition, and showed all the appearance of a bird that is picked up in a long frost. The exact locality, I believe, would be in Wothorpe parish, but it is in the occupation of a Stamford farmer and within 100 yards of Burghley Top, or deer-park, so that in reality the bird was found in Northamptonshire. This Lanius rufius I hope to place in my collection of British small birds. I have had several applications to purchase, also several gentlemen to see, the bird; it will be there for show." I was 
unable to go to Stamford at the time, and had no one to send upon whose identification of birds I could depend, so I will merely add that the date of this occurrence renders it doubly remarkable.

\section{SPOTTED FLYCATCHER. \\ Muscicapa grisola.}

This little summer visitor is so common and so well known in our county that a very few words will suffice with regard to it. In our neighbourhood it is generally known as "Cobweb;" why, I cannot well say, unless it may be on account of that material being occasionally used in the exterior of the nest. In some notes on the arrival of summer migrants, kindly supplied to me by the Rev. H. H. Gillett, formerly Rector of Wadenhoe, he gives the following dates of the first appearance of this species at that place:-1872, May $19 ; 1873$, May 17 ; 1874, June 12. From my own recollection, I should say that the first. of the days above given is about the usual date in this neighbourhood. A curious instance of the want of observation in our country people came under my notice with regard to this bird some few years ago. I was fishing on the Nen close to this house early in August, after a long absence from home, and my attendant, who had been all his life employed about the place as under gamekeeper, boatman, \&e., was anxious to give me all the natural-history news of the neighbourhood, and began by saying that a very curious pair of birds had appeared in his cottage 
garden, such as he had never seen before, and began to attack his peas. I at once thought that these wonderful birds must be Hawfinches, which have only of late years become common with us, and are great devourers of green peas, but my informant went on to state that to frighten these and other winged depredators, he had stuck up a battered old hat on a stick, and in said hat these unknown birds had immediately built a nest and laid their eggs. I then guessed what they were, and, pointing out a Spotted Flycatcher on a dead bough within a few yards of us, asked if that was anything like these builders in the hat. "Why, bless me, so it is!" was the answer, evidently given with genuine astonishment, though this Flycatcher is one of our most common, and, with the exception of the Swallow tribe, quite the most observable of our summer birds. I need hardly say that the propensity for peas was purely imaginary.

I think that this species generally rears two broods, as I have often met with young birds in the nest late in August. I once, and only once, met with a Cuckoo's egg in a Spotted Flycatcher's nest. The same nesting-site is chosen year after year, but the old nest is seldom even partially used. All sorts of curious situations are selected by these birds, but on the whole I should say the favourite nesting-places are creepers, such as ivy, honeysuckle, \&c., or the boughs of fruit-trees fastened to a garden wall. The young birds are fed by the old ones for some time after they leave the nest, and all take their departure about the second week in September. In the summer of 1889 a pair of Flycatchers made a nest and reared 
their brood in a standard rose-bush at the insertion of the first branches, about three feet from the ground, and within a yard of a much-frequented gravel-path at Lilford, and in 1893 a brood was hatched out within two feet of my head as I sat in my Bathchair in a favourite shady spot in our flowergarden.

\section{PIED FLYCATCHER.}

Muscicapa atricapilla.

Though I feel little doubt about once having seen a male of this species close to Lilford, in the summer of 1853, I only had a momentary and somewhat distant glimpse of the bird, and cannot therefore positively affirm that it was a Pied Flycatcher. Mr. A. G. Elliot, so often previously mentioned, informs me that he shot at and knocked down a bird of this species near Barkston, but lost it in some long grass. He does not give me the date of this occurrence further than that young pheasants were being reared at the time. I must confess that the only Barkston which I can find in the atlas appears to be a village in Lincolnshire, which would hardly come fairly within the limits to which I proposed to confine myself in these notes.

The Pied Flycatcher is a summer visitor to England, and breeds regularly in several of our northern counties, especially the Lake district of Cumberland and Westmoreland. It is not uncommon in certain parts of North Wales, the only British locality in which I have myself met with it. The nest is generally situated in the hole of a pollard willow or other tree, 
often in an old wall; in fact, very much in the sort of locality that we should look for a nest of the Common Redstart. The eggs are of a very pale blue, and generally five or six in number. Yarrell records an instance of eight in a nest, but, from my acquaintance with this species in Spain, I should consider that number as very exceptional. The male has a pleasant little song. I recommend my readers to look out for this little bird, which, though it may perhaps not nest with us, I feel sure must pass through our county on its migrations, and only requires searching for.

Since this article was written the following occurrences of this bird have come to my knowledge :-An adult male shot near Harleston on May 1, 1883, and kindly presented to me in 1891 by Mr. W. Tomalin. One seen at Williamscote, in Oxfordshire, within a mile of our county boundary, on July 26,1884 , by Mr. O. V. Aplin. One shot and another seen in Yardley Chase on May 3, 1887 (Mr. W. Tomalin). The bird shot is now in the Northampton Museum. An adult male was shot near Lilford on May 10, 1888 , and is now in my possession. A male Pied Flyeatcher was shot at Farthinghoe on May 2, 1888 (O. V. Aplin). Lieut.-Col. C. I. Strong informed me that he watched a male of this species for some time in his garden at Thorpe Hall, near Peterborough, on May 1, 1889. I received a report of the nesting of this species at Harleston in 1886, but as my informant only reported to me from a third person, I hardly feel justified in recording this as an ascertained fact. 


\section{GOLDEN ORIOLE.}

Oriolus gallula.

This fine species can hardly be considered very rare in Great Britain, as scarcely a year passes in which several, and in some instances a good many, are not ruthlessly shot down on their arrival, generally at the period of the vernal migration. Yarrell gives the particulars of several nests met with in England, and others are on record, so that there is little doubt but that, if permitted, the Oriole would become as common with us as it is in many parts of Holland, Belgium, Germany, and France. I am glad to say that I have no record of a bird of this species having met its death in our county, but it has been seen on several occasions. The earliest notice I have is in a list of birds observed at and about Milton, kindly sent by Lady Mary 'Thompson, who tells me that about the end of May or early in June 1836 she saw one of these birds in the garden at Milton, evidently, from the description given, a male in full plumage. Lady Mary tells me also that, on speaking on the subject to a Mr. Henderson, then gardener at Milton, who was a good observer and a collector of birds, he told her that he had seen the bird several times, and made several unsuccessful attempts to secure it alive or dead. I was informer by the late Mr. I. Watts Russell that a pair of Golden Oricles had haunted a large wood belonging to him near Benefield throughont one summer, and were supposed to have a nest there, which, however, was not found. I regret that I have not the date of this occurrence, but my impression is that it was between 1860 and 1865. In 
$1871 \mathrm{I}$ several times saw one of these birds about the lawn at Lilford in the late summer, and in 1879 was told of a bird that had been seen two or three times near the house in August and September, which, I feel convinced, must have been a female or young male of this species. I was informed by Miss A. Eden that in the last week of September 1883, she saw " a brilliant golden and black bird, about the size of a thrush," fly from a yew tree in the garden at Boughton House, Kettering, and Mr. G. M. Edmonds assures me that a bird answering to the above description was frequently seen by him and by his son, in and about Oundle, during the summer of 1892. The male Golden Oriole soon makes his presence known on his arrival in the spring by his clear, flute-like call, difficult to describe, but not particularly difficult to imitate to a certain extent, though the bird himself is rarely to be deceived by a human imitator. The Oriole has also a harsh, croaking note, often heard in the pairing-season, when the male is in pursuit of the female, or adjusting his differences with others of his own sex. These birds especially affect the outskirts of woods in the neighbourhood of streams, and generally frequent the thickest foliage they can find. They will permit a very near approach when they consider themselves well concealed, and, indeed, are with difficulty forced to fly from a secure hiding-place. I believe the principal food of the Golden Oriole to consist, in the spring and early summer months, of various caterpillars, grubs, and small earthworms; later in the year they seem to take to a fruit diet, and in the Ionian Islands, where they are abundant at the time of the autumnal migration, play havoc amongst the 
vineyards. Figs and cherries are also favourite food of these birds. In Spain the Golden Oriole is common almost everywhere in the summer, especially so in the outskirts of Madrid. The nest is very unlike that of any other European bird, being composed entirely of wool and long sedge-grass, and placed in the horizontal fork of a branch, generally, but not always, at a considerable height from the ground, and difficult of access, from being usually at or near the extremity of a long and slender bough. The eggs are generally five, of a glossy white, with very dark blue or black spots. I have found the young very difficult to keep alive for more than a week or two, though I know of instances in which they have been reared with success. I must add that I consider Northamptonshire as in most parts eminently well suited to the habits of this beautiful bird, and earnestly urge upon any of my fellow countymen who may have the good fortune to see an Oriole, to watch its habits as closely as possible, and refrain from shooting at, or molesting it in any way. There is no natural reason why this bird should not become a regular summer resident with us.

\section{DIPPER.}

Cinclus aquaticus.

This bird, though its favourite haunts are the banks of rapid mountain-streams and swift rivers, in which scattered fragments of rock and long reaches of gravelly shallows are constantly met with, has nevertheless occurred more than once to my knowledge in our county, which cannot boast of the 
above amongst its many natural attractions. I have a specimen, purchased of Mr. A. G. Elliot, who assured me that it was shot by one Mr. G. Hurcock at Blatherwycke Mill, April 29th, 1868, and that it was the only specimen that had ever come into his hands during a long residence at Stamford. My brother tells me that he several times saw a bird of this species (with which he is well acquainted) about our boat-house bridge on the Nen, within some 200 yards of this house, in May 1876; the bird was also often seen by two or more other persons not acquainted with the Dipper, but whose descriptions leave no doubt in my mind with regard to its species. About Easter, 1850, I saw what I have no doubt was a Dipper flying along the Nen a little below the locality just mentioned. I was too far off to be quite positive; but the only other bird it could have been is a Kingfisher, which it most certainly was not. Many instances are on record of the occurrence of the Black-breasted Dipper (Cinclus melanogaster), of Northern Europe, in Norfolk and elsewhere in this country; but the specimen above mentioned as in my possession is of the usual British form, Cinclus aquaticus, with the broad chestnut breast-band, which is wanting in the former race or species.

The Dipper is very abundant in many parts of England, Wales, Scotland, and Ireland, in such localities as those I have above described, and is probably well known to such of my readers as are given to trout-fishing. The actions of this bird under water are very curious; an interesting account of them will be found in Yarrell's 'British Birds,' 4 th ed. vol. i. p. 242 , which I have verified in every particular from personal observation - the most ex- 
traordinary part of the Dipper's proceedings, to my mind, being the way in which the bird sinks from the surface of the water, without, as almost all other birds which seek their food at the bottom, plunging or "taking a header." The Dipper sinks, if I may say so, horizontally, and, as may naturally be supposed, seems to have a good deal of trouble to keep below. These birds will go down in the most rapid streams and boiling pools below a waterfall, and, emerging with a jerk, fly off to a big stone, set up a short but very sweet song, and resume their subaqueous explorations. All their movements are sudden and rapid; they seem to be always in a hurry, and are eminently in keeping with the character of the streams which they frequent, and to which they add a great attraction. I am sorry to say that some years ago a crusade was instituted in many places against this most pleasant and cheery little bird, on the charge of devouring the ova of the Salmonidæ and other fishes. Yarrell (loc. sup. cit. p. 246) calls this a mistaken idea. I have examined the stomachs of three or four individuals shot in Inverness-shire and North Wales, and found nothing therein but the remains of various insects and a few small shells. I believe that opinions are still divided on this question, which certainly cannot be very difficult of solution, but for my own part, were I possessed of a salmon and trout stream frequented by these birds, they should, if their inclinations prompted them in that direction, be as welcome to the eggs of the abovenamed fishes as the Kingfishers now are to the small fry of our Nen. The song of the Dipper, though not very powerful, is very pleasing, and is associated in 
my mind with many delightful reminiscences of wild mountain and river scenery in our island and abroad. The male bird sits jerking his tail and warbling often amidst a whirl and roar of rushing waters, and, in manner, reminds one a great deal of the Common Wren; the song is continued throughout the winter months. The Dipper's nest is a large mass of green mosses, sometimes, but not always, lined with leaves of the alder, birch, beech, or willow, with a hole at the side, generally placed in a rocky bank or a hole in old masonry close to a stream, often under a waterfall. The eggs are from five to seven, of a pure white. I have often attempted to rear young Dippers, but never succeeded; about three months is the longest period I have ever managed to keep them alive.

Since the above article was written a few more occurrences of this species in our county have come to my knowledge: $e . g$., a very fine specimen shot in Broughton Field, near Kettering, on January 30th, 1886, reported to me by Mr. J. G. Field, of Kettering, from whom I subsequently purchased it, and presented it to the Northampton Muscum. A good specimen of the Black-breasted Dipper, above referred to, was shot at Raunds Staunch, about half a mile above Ringstead Station, L. N. W. Railway, on November 18th, 1889; and through the good offices of Mr. F. Dyer, of Ramsgate, is now stuffed in my possession. About the end of 1892 a Dipper was several times observed, by persons well acquainted with the species, haunting an open spot below Lilford Locks. 


\section{MISTLETOE-THRUSH.}

Turdus viscivorus.

This bird, generally known in Northamptonshire as Missel-Thrush or Stormcock, is, I think, as abundant with us as in any part of England with which $I$ am acquainted, though it appears that it was not always so, for Morton, whose ' Natural History of Northamptonshire' was published in 1712, states, at p. 425 of the said work:- "The Missel Bird, or Shrite, which is found nowhere with us, that I can hear of, unless in Lacy and Whittleborough forests, where it abides the whole year, and breeds with us." Willughby, however, in his 'Ornithology,' published in 1678, gives a full description of the bird, its habits, \&c., and evidently dicl not consider it as uncommon in England. In Bewick's time the Missel-Thrush seems to have been very rare in the north of England, but is certainly not so now. In fact, I have reason to believe that this species has for many years past been extending its range over our lslands, and is now abundant in many parts where it was formerly quite or nearly unknown. In the south-west of the Queen's County, for instance, where I found a few of these birds in 1853, I was told that they had only made their appearance in that district within three or four years previously, and were universally known as "Jays." This bird and its nest are so well known in our country, that a detailed account is hardly necessary. The chief peculiarities of the Missel-Thrush are its habit of singing in a gale of wind, and often in the depth of winter, and the courage with which it will defend its eggs or young from the attacks of feathered and 
four-footed enemies. This Thrush nests very early, and rears two broods in a season. In September we meet with them in small flocks frequenting our pasture-lands, and apparently finding their food on the ground. In an ordinary winter they take to the thorn bushes and fences in search of berries; but very severe weather drives most of them southwards, though they will linger on with us longer than the winter 'Thrushes,-Fieldfare and Redwing. The Devonshire name for this Thrush is "Holm-screech," in parts of Berkshire it is known as "Yelpingale;" in Warwickshire I have heard it called "StormThrostle;" and somewhere "White-Felt," i.e. White Fieldfare. Gardeners accuse the Missel-Thrush of being very destructive to varions kinds of fruit, but I know of an instance of a pair of these birds nesting in an apple-tree in a fruit-garden and remaining unmolested by the gardener, who condoned their depredations, as he said, because they allowed no Blackbirds, Song-Thrushes, Jays, or Squirrels to intrude upon their domain. I have myself seen one of these birds fly furiously at a Squirrel, and, being joined by his mate, drive the little animal from bush to bush to a considerable distance from their nest.

\section{SON G-T H R U S H.}

Turdus musicus.

The Song-Thrush, or, as it is generally called in this neighbourhood, Mavish (properly Mavis), is exceedingly common with us, and I fear that I can relate nothing with regard to its habits which is not already well known, except, perhaps, the fact, which does not seem to be very generally recognized, that it 
may fairly be called a migratory bird, large numbers arriving in our county early in September, and after remaining for a week or more, resuming their journey southwards, taking with them a large proportion of our native Thrushes. My attention was first called to this in my carly shooting-days, when I often noticed that the turnip-fields throngh which we had tramped during the first few days of the season, without disturbing more than a few young SongThrushes, would suddenly, a little later, seem to be alive with them for some days, and as suddenly, and without apparent cause, be entirely deserted. Some few of our native Thrushes linger, but generally disappear at the first severe frosts; and though I have not a regular record, I can well remember more than one winter in which $I$ have not met with more than one or two half-starved Song-'Thrushes between the end of October and beginning of February, in the first fine days of which month we generally hear the welcome song of the Mavis. In many parts of Europe the flesh of this species is highly esteemed and fetches a good price ; at Marseilles, especially, I have often found the markets full of this and other species of the 'Thrush family in the month of November; a great many are shot and snared in the neighbourhood, but hundreds of thousands are sent from Corsica, whither these birds swarm on their winter migration, to feed on the various berries which abound in the uncultivated parts of that island. I have more than once met with a nest of this bird on the ground, and in one such instance, on disturbing the old bird, found four eggs actually afloat in the nest, which was more than half full of water, I presume from some heavy thunder-showers, to which, in the absence of the Thrush, it was fully 
exposed. I emptied the water from the nest, which I carefully replaced, and a few days afterwards found the parent bird sitting hard, as if nothing had happened; she, however, did not succeed in rearing a brood, as the eggs were destroyed by some predatory animal, which, I am inclined to think, was a Squirrel. I have several times found old nests of this bird in the winter months entirely filled up with moss and beech-leaves, and was rather puzzled to account for this, till I one day found a pair of Dormice fast asleep in one of these snug resorts, a Song-Thrush's nest, from which two broods had been reared during the previous summer. I have seen more than one pied specimen of this bird in our neighbourhood.

\section{RED W IN G.}

Turdus iliacus.

The Redwing arrives in our neighbourhood from the north generally during the last days of September; on reference to my journals I find that the 25th of that month is about the usual date for their first appearance with us, though for $1869 \mathrm{I}$ find no record of having observed any till October 7 th. With us the Redwing seldom arrives in abundance at first, but in ordinary circumstances its numbers keep increasing gradually, till sometimes the hedge-rows and thorn bushes swarm with them, until the frosts scatter and eventually drive them all away. This bird is said by Yarrell to be less of a berry-feeder than most of the other species of the genus. It certainly seems to be one of the first to suffer from frost and consequent hardness of the ground, and, as most of my readers must have observed, is more often 
found dead from natural causes than perhaps any other British bird. In March the Redwings usually reappear in force on their return towards their breeding-quarters, and, as a rule, are gone by the middle of April, though a few stragglers occasionally linger with us till May, and I have more than once heard a Redwing and a Nightingale on the same day. Instances of this bird's breeding in our Islands are on record, but do not seem to be very clearly authenticated, the principal breeding-resorts in Europe being Sweden and Norway.

A nest of this species in my possession much resembles that of the Blackbird, though considerably smaller, being made of small twigs and moss, with a coat of dried mud and a lining of grass; the eggs belonging to this nest were four in number, and might be mistaken for minute varieties of Blackbird's eggs from their general colour and style of markings, though they are more pointed than those of that bird. The late Mr. John Wolley, to whom European ornithologists must always remain vastly indebted for his laborious and wonderfully successful researches in Northern Europe, is quoted in Yarrell's 'British Birds,' 4 th ed. vol. i. p. 269, with regard to the nesting of this species in Lapland, as follows :- "It makes its nest near the ground, in an open part of the wood, generally in the outskirts, on a stump, a log, on the roots of a fallen tree, sometimes amongst a cluster of young stems of the birch, usually quite exposed, so as almost to seem as if placed so purposely, the walls often supported only by their foundation." It appears that opinion is much divided as to the song of the Redwing. It has been called the northern Nightingale, but though it seems that Linnæus considered that its notes rivalled those of the real Nightingale, 
Mr. Wolley, above quoted, tells us that, in his opinion, the music of the Song-Thrush is infinitely superior. I believe that few birds sing as they should and can sing till their mates are on their nests, so that I fear, in this country, we must continue to take the Redwing's musical powers on trust. I append dates of first records of appearance of the Redwing in the neighbourhood of Lilford from my note-books for the following years :-1880, September 23; 1881, September $30 ; 1882$, October $3 ; 1883$, September 26 ; 1884, September 25; 1885, September 25; 1886, September $10 ; 1887$, September $20 ; 1888$, September $24 ; 1890$, September $24 ; 1891$, October 7 ; 1892, October $11 ; \mathbf{1 8 9 3}$, September 2 . A very beautiful, nearly pure white variety of this bird was shot by Mr. Walter Stopford, near'Tichmarsh, on December $21,1893$.

\section{F I E L D F A R E.}

Turdus pilaris.

This bird, commonly known in our neighbourhood as Felt, or Pigeon-Felt, generally appears with us about the last week of October. I find in my journal the following scattered notices of my having observed it in the years mentioned:-1861, October $26 ; 1872$, October 23; 1875, October 26. My neighbour Mr. George Hunt informed me that in 1879 he did not observe any Fieldfares in our district till November 1st, and in a letter dated November 28 of the same year he wrote:- "I have not seen a Fieldfare for three weeks, and have only seen about a score altogether." Many notices of the scarcity, and some of the total absence, of this species in different parts of the king. dom during the winter of $1879-80$ appeared in various 
publications, and as many of its great abundance during the same season of 1878-79. I think there can be no doubt that many of this and other species were destroyed by the continuous frosts of the lastnamed winter. In an average season great numbers of Fieldfares visit us, though they are never, I think, so abundant in this county as the Redwing, but they are not so soon driven away by severe weather, and more or less usually remain with us throughout the winter, a few often lingering in their favourite haunts till late in May.

Mr. G. Hunt, above quoted, had a specimen of this bird stuffed, which he shot near Wadenhoe in the month of July many years ago, but though several such occurrences are on record, they are decidedly exceptional, and although instances of the nesting of this species in England have been published circumstantially, I observe that the editor of the fourth edition of Yarrell's 'British Birds' (than whom there is no higher authority on the subject) states, op. cit. vol. i. p. 273 , that not one of these supposed instances seems to be free from reasonable doubt. Our old friend Morton says of the Fieldfare:- "According to Mr. Willughby, they all fly out of the country in the spring, not so much as one of them remaining, which perhaps may be true as to most other parts of England; but yet in this county I have seen here and there one in all the summer months." 'The true summer-home of the Fieldfare is the north of Europe, where it seems that these birds breed in society. For a description of the nest and eggs I refer my readers to the many English writers who have seen and handled them in situ, especially Mr. Hewitson, as quoted in Yarrell's 'British Birds,' loc. suprà cit. 'This species is a winter visitor 
to most parts of Europe, but decidedly uncommon in Spain, and amidst many thousands of Song-Thrushes, Blackbirds, Redwings, and a few Ring-Ouzels, in the market of Marseilles in November 1874, I only noticed one Fieldfare : I only once saw it in European 'Turkey, but have a specimen from Cyprus. One of these birds which I kept caged for some months

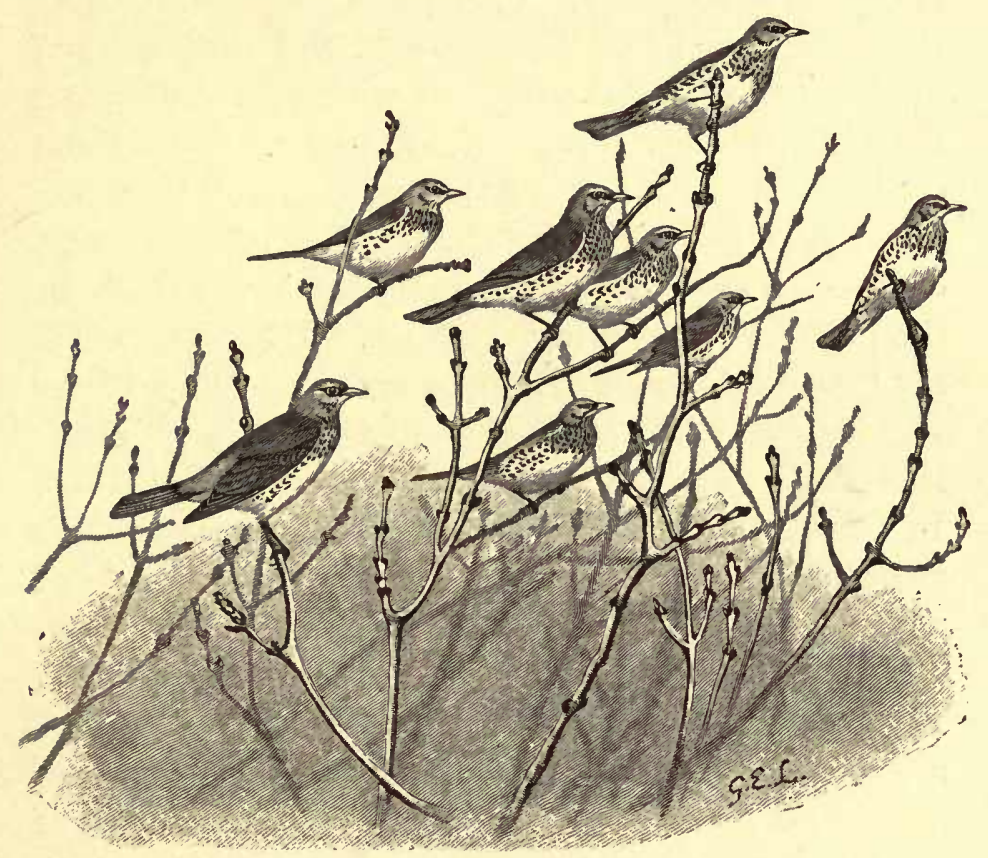

Fieldfares.

became tame, and appeared to me to attempt an imitation of the song of his cousin and neighbour in captivity, a Black-throated Thrush (Turdus atrigularis). The earliest record of first appearance of the Fieldfare at Lilford that I can find in my note-books since 1861, upon which I can positively depend, was on October 9, 1885, but several rumours of September appearances have come to my ears. 


\section{B L A C K B I R D.}

Turdus merula.

The Blackbird is so well known throughout England, and its habits so easy to observe, that any detailed notes thereon would be superfluous. I will therefore content myself with saying that with us it is especially abundant, that its numbers are increased every autumn by an immigration, and that more of these birds remain through the winter in our district than of any other species of the genus. I have not observed in the Blackbird the habit so well known in the case of the Song-Thrush, viz. that of selecting a convenient spot to which to carry the larger snails for the purpose of breaking them up. I have met with the Blackbird in every European country which I have visited, and was surprised to find it nesting in the immediate neighbourhood of Algiers in April 1878. In Yarrell's 'British Birds' I read that the Blackbird's "strain is never better than during a warm April shower;" and I well recollect that it was a common saying in our district, when I was a child, that the Blackbird would only sing his best when he had had a good shower to "wet his whistle." I know of several occurrences of white and pied specimens of the Blackbird in our county; a fine old male with pure white wings haunted the flower-garden at Lilford for several years. I believe that the Blackbird, as a rule, nests thrice in the year; instances of its doing so four times are on record.

Between the end of January and the first week of April 1884, a " golden-coloured" Blackbird was constantly noticed by our gamekeepers and several other persons haunting the fence of one of our plantations, by the roadside between Barnwell and Lilford cross- 
roads. My son, who at my request, went to have a look at this bird on April 5, described it to me as being exactly of the colour of an Australian sovereign. Another yellow Blackbird was reported to me as having been observed in the curtilage of Achurch Rectory on November 4, 1887, and on February 10, 1888, my son wrote:- "I saw on Monday last a yellow Blackbird in the Achurch Rectory curtilage. It was pure yellow, without a black spot upon it, and of a lighter colour than the 'golden' bird of 1884."

\section{R I N G- 0 U Z E L.}

Turdus torquatus.

The Ring-Ouzel is a pretty regular though not a very abundant autumnal visitor to our country. I have also twice observed the bird in our immediate neighbourhood on its return migration about the end of April, and have little doubt that its passing visits are as common at that season as in the autumn, though, from my usual absence from home in the spring, I have been unable to carry out any regular observations with regard to its appearance at that time of year. In autumn the Ring-Ouzel generally arrives about the beginning of October, on the 12th of which month, 1878, I observed an unusually large number of this species haunting a tall fence well stocked with berries, near Tichmarsh, but I have several records for September, of which the earliest is Sept. 13, 1884; and one for August 1882, from Hazelbeach. I shot a Ring-Ouzel not far from Lilford as late as October 29 th in 1860 ; but this was a lingerer, and the only instance in which I have seen 
the bird in Northamptonshire so late in the year. I should put the average date of their appearance with us at about October 3rd; they seldom remain more than a few days, and are generally to be found year after year in greater or smaller numbers in or about the same spot, though this depends of course on the abundance or-scarcity of their favourite food-hips and haws, blackberries, \&c. I have several records of the occurrence of this bird in various parts of the county, and have no doubt that it is often mistaken for a Blackbird, to which in shape, size, and flight it bears a close resemblance, though the alarm-note of the rarer bird is a sufficient means of distinction. Morton says of the Ring-Ouzel:- " A bird usually conversant about the rocks and steep cliffs of high mountains. With us it has bred in bushes on the sides of a pretty steep valley between Clipston and Marston, in Clipston Lordship. We shot a cock Ring-Ouzel there on April 6, 1710." It is difficult to make out from this whether our old county historian intends to convey that he considers the fact of his finding a Ring-Ouzel on April 6th as sufficient proof that it had a nest in the locality, but I incline to think not, and that he had actually known of a nest, though he gives us no particulars. The favourite and usual summer haunts of this species are wild hilly moorlands, rocky mountain-sides, and glens : it is especially abundant on Dartmoor, a locality eminently suited to its habits, I also found it common on the Cheshire Moors near Buxton, and in all parts of Scotland that I have visited for grouse-shooting. 'The nest, which is usually built of fine twigs of heather and lined with dry grass, is built on, or quite close to, the ground, among large fragments of rock or in a tuft of rank heather amongst stones; the eggs 


\section{(....}

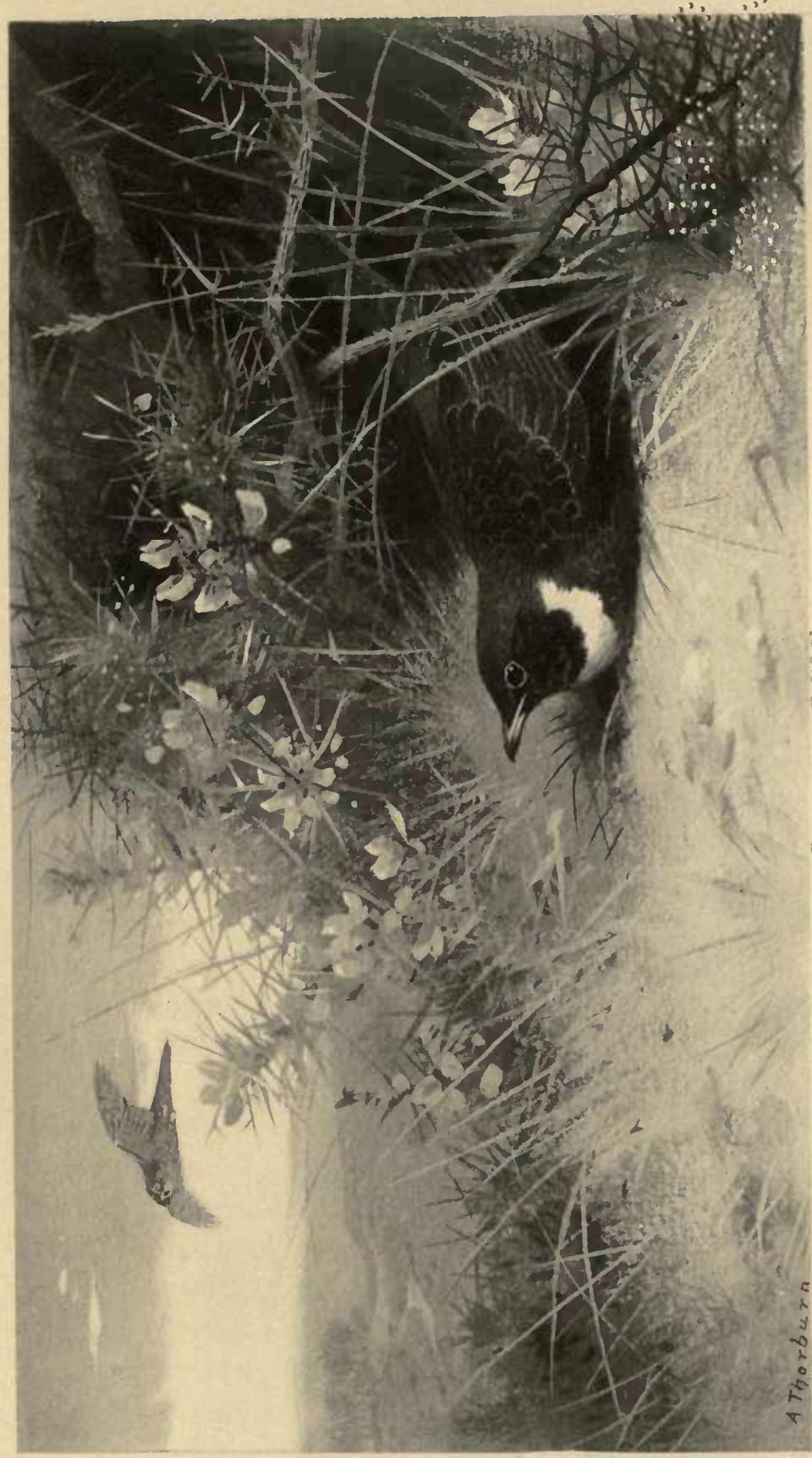

है

है

है है 

are five or six, and very closely resemble somp: $\because \because \vdots$. varieties of the Blackbird. Captain J. Borlase,

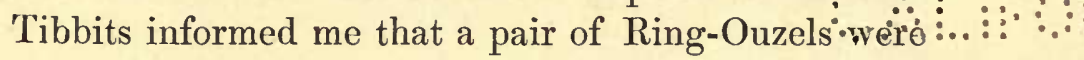
constantly seen about his garden at Rothwell Grange in May and June 1891, but that no nest could be discovered there.

The Ring-Ouzel has a pleasant clear whistling song. An old male which I kept for many years became very tame, and sang so vigorously in the spring that I found it absolutely necessary to banish him from my room; this bird became totally blind after some years in captivity, but lived on in good feather and in good health for at least two years after its sight was completely gone, and sang in the springtime as gaily as ever. The alarm-note of the RingOuzel, to which I have before alluded, is a harsh chatter, something between that of the Blackbird and the Fieldfare, but very distinct from either. In captivity I find that these birds will thrive, when wild berries are not obtainable, upon currants, raisins, scraped carrots, hard-boiled egg, and chopped beef, they will also greedily devour all sorts of beetles, earthworms, flies, and spiders.

\section{HE D GE - S PAR R 0 W.}

Accentor modularis.

This little bird is so common, and so familiar in its habits, that every one is well acquainted with it; and did it only possess the brilliant colour of the Redbreast it would, no doubt, be as great a favourite amongst us as that bird, and deservedly so, for though perhaps not quite so fearless of man, it seems especially to affect the neighbourhood of human habitations 
during the winter months, is entirely harmless to fruit or garden vegetables, and has a pleasant little song, which may be heard throughout the year, nor has it, so far as I know, the pre-eminently pugnacious temperament of the above-named bird. Insects, as long as they are obtainable, form the principal, if not the entire, food of this species. In the frosts of winter the Hedge-Sparrows cluster about sinks and drain-mouths in search of crumbs and other refuse, and are always, with us, amongst the first visitors to the scraps thrown out from the windows in severe weather. This is one of our earliest nesters; I have several times found the full complement of eggs before the middle of March, and the first broods are generally out and about before the end of April. In our immediate neighbourhood I do not think that the Cuckoo selects the nests of this bird in which to deposit her egg so often as seems to be the case in other parts of England, though both Cuckoos and Hedge-Sparrows are certainly as common as in most parts of England. In Spain I have only met with the Hedge-Sparrow in the summer months, in scattered pairs, and always at an elevation of several thousand feet above the sea. The curious quivering motion of the wings in this species has probably been remarked by most of my readers, and is, I think, quite peculiar to it. It is perhaps superfluous to say that, in habits, food, and conformation, this little bird has no affinity with what are properly called Sparrows, but I believe that in old times the term Sparrow was used merely to convey the idea of a small bird, as, for instance, BrookSparrow, Reed-Sparrow, and (a name I once heard) Moor-Sparrow, as applied respectively to the ReedBunting, Reed- and Sedge-Warblers, and MeadowPipit. In the fourth edition of Yarrell's 'British 
Birds,' 1st vol. pp. 303, 304, will be found some valid reasons for adhering to the established name of Hedge-Sparrow for this species; the only other by which it seems to be known is Dunnock, but I never myself heard this used in any part of the country. The Hedge-Sparrow usually rears two, and sometimes three broods in a season, but from the situation of the nest, the eggs are very often discovered and devoured by mice and rats; I have known of seven out of eleven clutches of eggs of this bird thus destroyed in one season.

\section{REDBREAST.}

Erythacus rubecula.

I can add nothing worthy of record to the mass of accessible and trustworthy information already in print with regard to this well-known and favourite bird. In most of the countries on the Mediterranean it is a winter visitor, and in South France and Italy is esteemed for the table, but I have not found that it is more thought of from a culinary point of view in those countries than the many other species of small birds which are to be found hanging by dozens in the markets at the time of the autumnal migration. That the Redbreast is a migratory bird is obvious to the most ordinary observer who lives in the country, for whilst in September and October our shrubberies and lawns are full of young and old Robins, and furious battles raging in every direction, in the dead of winter their number will be reduced to comparatively few pairs, each of which keeps a district or beat to itself, and impetuously resents the intrusion therein of a stranger of the same species. We had for some 
years in the flower-garden at Lilford a male Redbreast, who had somewhere picked up a song entirely unlike his natural sweet but melancholy strain, that he seemed to have entirely lost. I am no musician, and cannot attempt to describe this acquisition; it was loud, short, but not very sweet, and had I not repeatedly seen the bird in the act of giving utterance to it, I should, I think, have attributed it to some escaped foreign Finch or other hard-billed bird. The wailing note of the Redbreast when in fear of danger for its young is peculiarly plaintive and touching, and has more than once attracted my notice to the presence of a prowling house-cat or weasel. I know of two instances in which a pair of Redbreasts dispossessed other birds of their nests; in one case a Nightingale was thus ousted from her domicile, in which she had laid two eggs, in the other a Redstart was the sufferer. I have several times met with clutches of pure white eggs of the Redbreast, and once with a nest containing six eggs, of which two were white and the remainder of the usual colour. A wild Robin will become perfectly tame in a few days if a little food is gently thrown down in his sight by the same person, and he is not startled by any sudden or abrupt movements. One of these birds, of whom I had made a friend by giving him morsels of ground-bait every morning for a week, became so fearless, that he more than once perched on my fishingrod as I held it over the water, and came towards me every day as I approached the river with a chirp of welcome. If I took no notice of him at once, he would set up an impetuous tick, tick, tick, and settle close to me with a sort of "you know what I want" look about him that was quite irresistible. 


\section{N I G H T I N GA LE.}

Daulias luscinia.

This well-known charming songster is, I think, as abundant in North Northamptonshire as in any part of England with which I am acquainted, as might naturally be expected from the character of the district, abounding as it does in streams, bushy copses, and mossy banks, overgrown with ivy and other creeping-plants-in fact, an infinite variety of the favourite haunts and nesting-places of this welcome spring visitor to our country. On account of my usual absence from home during the spring, I am unable on my own authority to fix an average date for the arrival or first hearing of the Nightingale in our neighbourhood, but from information kindly supplied by two gentlemen interested in the subject, and resident in the district, whose observations extend from 1860 to 1875 , it appears that April 20th is about the day one may expect the pleasure of hearing this sweet singer. The earliest date given in the notes above mentioned is April 13th, the latest May 4th, but, as is probably well known, these birds are occasionally silent for some days after their first arrival, and I well recollect on one occasion finding a Nightingale in one of their favourite haunts a full week before I heard the song. The male birds arrive considerably sooner than the females, as I have repeatedly observed, and if caught before they have paired, and treated with care, are not difficult to keep and will soon sing, but I have found the young birds exceedingly hard to rear in the few instances in which I have attempted to do so, and consequently let them all go as soon as they could fly. I know 
of more than one case of a Nightingale living and singing in captivity for many years; but I could never make up my mind to keep one caged when the time of migration arrived, and so turned off the only two old birds I ever possessed with a hearty God-speed. Particulars of the vast numbers of Nightingales occasionally caught around London, and the mortality amongst them, will be found in Yarrell's 'British Birds,' fourth edition, 1st vol. pp. 313, 314.

It is a curious fact that the Nightingale seems to avoid, or, at all events, very rarely to visit, the western portions of England. It is uncommon in Devonshire, and has not, I believe, been met with in Cornwall. In Wales it appears to be confined to one or two localities in the south-east of the Principality, and in Ireland it is entirely unknown.

I have found the Nightingale very abundant in the summer in many parts of the south of Europe, nowhere more so than in the grounds of the Alhambra of Granada.

All the many nests of this bird that I have found, save one, have been situated on, or within a few inches of, the ground; the exception was in some stacked faggots, at a height of between three and four feet, and contained five eggs, of the spotted variety which occasionally occurs. I believe this bird to be naturally almost exclusively insectivorous, although in captivity it will feed readily upon currants and other berries.

Since the above article was published, I have many records of the first seasonal appearance of Nightingales in our neighbourhood during the first week of April. 


\section{REDSTART.}

\section{Ruticilla phœenicurus.}

'This pretty bird, commonly known amongst us by the name of Firetail, is one of our earliest spring migrants, generally putting in an appearance in the first week of April. Though not very abundant with us, it is by no means uncommon, and is a well-known bird, as its bright and contrasted colours, the curious quiver of the tail, and short sweet song must attract the attention of the most unobservant. In our neighbourhood the Redstart is generally to be seen near buildings, and often selects holes in old masonry as a nesting-site, but it is also very fond of old pollard willows for that purpose, and often chooses very curious and apparently unlikely localities.

In Spain I found the Redstart very common, especially in the province of Santander, haunting the forests of oak and beech at a considerable elevation, and leaving the neighbourhood of the mountainvillages to its congener, the Black Redstart (Ruticillu titys), a bird which has frequently occurred in various parts of England, and appears pretty regularly in November in the neighbourhood of Plymouth. I possess a fine adult male which was killed in our neighbouring county of Oxford.

Our common Redstart is a very omnivorous bird, and not difficult to keep in captivity; all sorts of insect food, most fruits, and scraps of potatoes, carrots, and chopped meat seem to be equally acceptable. This species often takes insects on the wing, in the same manner as the Flycatchers; in fact, in habits it seems to unite some of the characteristics 
of that family with those of the Redbreast, though it is naturally of a much more timid disposition than the last-named bird or our commonest English representative of the Flycatchers. I think that two broods are generally reared by these birds, as I often see young birds in August which cannot have left the nest long. The editor of the fourth edition of Yarrell's 'British Birds' tells us that the second syllable of this bird's common name is derived from the Anglo-Saxon steort, a tail. I mention this as, till I read the article "Redstart" in the work just quoted, I had often puzzled over the meaning of this word, and I imagine that many of my readers may be in the same predicament. The eggs of this bird are generally six in number, and, from their paler shade of greenish blue, can, I think, hardly be mistaken for those of the Hedge-Sparrow, as, besides the slight difference in shade, they are considerably smaller than those of that species. To the finder of the nest, of course the situation is a sufficient indication of the species, as I never yet knew of an instance of the Hedge-Sparrow nesting in any situation which the Redstart would select, and I think I am authorized in stating that the converse holds equally good.

\section{BLACK REDSTART.}

Ruticilla titys.

The Rev. H. H. Slater was good enough to inform me privately of the only occurrence of this species in Northamptonshire that has come to my knowledge; and has recorded it in the 'Zoologist' in the following words :- "A bird of this species, apparently an adult female, was haunting the steeple of this 
(Irchester) parish church on Sunday, December 2nd, 1883, and feeding busily" (op. suprà cit. 1884, p. 31). Mr. Slater has since this informed me of a fairly circumstantial report of the nesting of this species in a garden-wall at Orlingbury, but I feel hardly warranted in recording this as an established fact on the evidence at present in my possession. I have met with this bird in most parts of Europe that I have visited during the summer months, and have seen it in winter in the north of Spain, Algeria, and Tunis. In Rhenish Prussia it frequently nests in walls in towns and villages in the low country, but in Spain it appears to prefer the mountains during the breeding-season; I found a nest in a cattle-shed near Panticosa in Aragon at some 6000 feet above sea-level, and have frequently seen Black Redstarts at greater altitudes than this in the Spanish Pyrenees. From the 4th ed. of Yarrell's 'British Birds' I gather that there is good evidence, but no actual proof, of the breeding of this bird in Great Britain; but the great majority of records of occurrence in our country hare reference to the months of late autumn and winter. In the work just quoted will be found some very interesting notes by Mr. Gatcombe upon the regular appearance of this species at and ahout Plymouth. The Black Redstart, in habits, materials of nest, and to some extent in song, resembles the Common Redstart; but I have never met with, or to the best of my recollection heard of, a nest of the present species in a tree. The eggs of this bird are pure white and generally five in number. 


\section{STONECHAT.}

Pratincula rubicola.

The Stonechat is by no means a common bird in our immediate neighbourhood, probably because we have little or none of the moory rough ground in which it delights, but I occasionally meet with it in the month of September frequenting low cut fences on the arable land; it is much more common in the neighbourhood of Stamford, and I find that Morton, so often previously quoted, says (Nat. Hist. Northamptonshire, p. 427) that "The Winchat, Enanthe secunda of Mr. Willughby, is common in the gorzy grounds nigh Kelmarsh and Clipston, and in the bushy parts of the heathy grounds about Halston." I feel sure that this refers to the present species, and not to the bird now commonly known as Whinchat, for, on the previous page to that from which I have taken the above, I observe that our author mentions the Winchat (without the $h$ ) as one of the small birds which "abide the winter with us"; and this we know the true Whinchat does not. On reference to Willughby, however, I find that, having described the Wheatear as "Enanthe sive Vitiflora of Aldrov.," he gives a short description of "the other WEnanthe of Aldrovand," which may be the Whinchat, and goes on to describe the "Stone-smich, Stone-chatterer, or Moor-titling (Enanthe nostra tertia)," of which he gives a very quaint, but recognizable figure. It is probable that Morton was well acquainted with both species, but somewhat puzzled as to which of them really remained to brave the severity of our Northamptonshire winters. 
In many-I might, I think, say in most-parts of England, Scotland, and Ireland the Stonechat is common and well known, as it appears especially to affect the neighbourhood of roads and footpaths which run through open heathy and furzy grounds, avoiding high trees, and flitting from bush to bush or stone to stone with a jerky flight and impatient clicking note. The male bird has a short but pleasant song, often uttered on the wing, and altogether the Stonechat is a species which is not likely to escape notice, from its restless habits, and the devices of the parent birds to attract the attention of passers-by from their young or eggs, which, by the way, are sufficiently difficult to find without any misguidance, the nest being generally well concealed at the foot of an almost impenetrable furze or scrubby thorn bush, and often in the midst of a dense furze-brake. With the single exception of the Grasshopper Warbler, I do not remember any ground-breeding bird which has given me more trouble in finding its nest than the Stonechat, and though I have spent many hours in searching for them, and in watching the old birds, I have only succeeded in finding three nests, all in such situations as those above described, built of moss and rough grass, lined with fine grass and hairs, and containing five pale-blue eggs, thickly spotted with rusty red. 


\section{W H I N C H A T.}

Pratincola rubetra.

The Whinchat is a regular, but not a very abundant, spring visitor to our neighbourhood. From my own observation I should say that the Stonechat last described merits the name of Whin-, i.e. Furze- or Gorse-Chat, much more than the present species, which I have generally found in England haunting grassy meadows, and particularly grass-grown railway embankments, without, so far as my own observation goes, evincing any special partiality for the furzebrakes which have such an attraction for its congener. The Whinchat arrives in our district about the third week in April, and from that time may generally be met with year after year in pairs in or about the same spots. 'The male has a pleasant song and is a sprightly pretty bird, in many of his actions reminding one of the Red-backed Shrike, especially in the habit of darting from his perch on a bush or clod of earth in pursuit of insects, and returning to the same look-out station after each excursion. 'The ordinary call- or alarm-note of this species is a very distinct "U-tick" several times repeated; and in some parts of England the bird is known by that name. About the second week of September I often see considerable numbers of Whinchats, many more than are bred in our district, haunting arable land for a few days on their southward migration, but their stay is very short and I do not recollect to have met with one after the end of that month.

The nest of this bird, though not so difficult to 
discover as that of the Stonechat, is not often to be found without considerable patience and trouble, unless, indeed, the bird is accidentally disturbed from it by a dog or a person passing within a few inches, for the hen sits very close, and one may watch the male for hours without his affording the slightest indication of where his treasures lie hidden. The few nests which I have seen have been situated in a slight cavity of the ground, sometimes in an open field, but for the most part on a sloping bank, always well surrounded and concealed by rank herbage, and composed of coarse grasses and sometimes a little moss, lined with fine fibres and horsehair, and containing from four to six eggs, of a darker shade of blue than those of the Stonechat, and, like them, closely spotted with rusty-red spots. I believe that the Whinchat generally rears two broods, but of this I cannot speak positively. I have met with this species in many parts of the South of Europe in the summer months, but nowhere in what I should call abundance; in Spain, for instance, though I have seen the bird in various parts of the country, it is far from common, and amongst the multitude of our summer migrants which pass through Algeria on their northward journey I found this species comparatively rare. I have kept a Whinchat for some time in captivity, and found that he thrived well upon ants' eggs, house-flies, occasional beetles, and hard-boiled eggs. 


\section{W HEATEAR.}

Saxicola cenanthe.

The Wheatear is our earliest spring visitor, often arriving in the first week of March, and almost always to be found about the same day, year after year, in or close to the same spot. In our immediate neighbourhood it is by no means abundant, and I only know of one breeding-place, but a little further north it is much more common, and in some places on the frontiers of Northamptonshire, Lincolnshire, and Rutland may be called abundant. Our old county historian, Morton, says of the "Fallow Smich or Wheat-Ear (Enanthe sive Vitiflora, Aldrovand), there are not only great numbers of them upon the Downs in Sussex, as Mr. Willughby observes, but in Northamptonshire too, and that not only in the Clayland fields as about Oxenden, but in those of a lighter soil, as about Oundle, where some call them Clodhoppers. In our Red land they nest in forsaken Coney burrows, and in the clefts or intervals of the Keal and Quarry stone." The Wheatear loves open country, dry moorlands divided by stone walls, rolling downs, sandy rabbit-warrens, grassy mountain-sides strewn with rocks and boulder-stones, and in such localities I have met with it from the Land's End to Inverness-shire. We generally see a few of these birds early in September about our fallow fields, but not in such numbers as the Whinchat, and their stay with us at that season is even shorter than that of the latter species. The Wheatear is a restless fidgety bird, and very much enlivens some of the dreary localities in which it is often found, as, for instance, 
certain parts of the Peak of Derbyshire, where, with the exception of a few Peewits, an occasional MeadowPipit, and rarely a Kestrel, the present species seems to be the only feathered inhabitant, flitting from stone to stone, or along miles of wall, in front of the traveller, with a low wailing note, and occasionally darting down to pick some insect from the road. The nest of the Wheatear is generally placed in the crevice of a stone wall, or a crack or hole in a stonequarry, sometimes under a large rock or boulder, and very often, as Morton tells us, in an old rabbitburrow; it is a large, loosely built structure, usually of rough grass and hair, but varies according to its locality, a good deal of wool and moss occasionally entering into its composition. 'The eggs, generally five or six, are of a very pale blue, for the most part spotless, but now and then marked with a few rustyred spots. The Wheatear has a low soft song, pleasantly varied, but only audible at a short distance. Both parent birds become very much excited at the approach of an intruder when their young have left the nest, and I have seen them attack a terrier dog in these circumstances with great determination. I have met with the Wheatear in every part of Europe that I have visited, but, as a rule, I think it does not, breed in the countries that border the Mediterranean.

The curious complete change of plumage in this species at the annual moult which takes place in August has led to some confusion in the discrimination of the sexes and the age of the birds. It may be briefly and roughly described as a general change from a fine blue-grey to a light rufous, and is effected by a true moult, or shifting of the old feathers for new, and not by an alteration in colour of the original 
feathers. Wheatears were formerly caught about the end of summer on the Sussex downs in very large numbers by the shepherds, in very simple though ingenious traps, but, according to Yarrell, it appears that, whereas the selling price for these birds in 1802 was one shilling the dozen, in 1872 the price demanded by the Brighton poulterers was three shillings and sixpence. It seems that one great reason of the rise in price is the present comparative scarcity of the birds in consequence of the ploughingup of the virgin downs and other open places which were formerly their favourite breeding-haunts. At the season at which they are thus taken, the Wheatears, chiefly young birds of the year, are generally very fat and certainly most exquisite food, although I believe exclusively insectivorous.

\section{GREAT REED-WARBLER ?}

Acrocephalus turdoides?

Although my friend Mr. J. E. Harting, in his ' Handbook of British Birds,' includes this bird in the first portion of that work amongst "Residents and Migrants," and designates it as "an occasional summer visitant to England," it appears that more than one of its recorded occurrences in this country are open to doubt, and my only reason for according it a place in this list is that I find in Yarrell's 'British Birds,' 4th ed. vol. i. p. 366, that Mr. John Hancock, of Newcastle-on-Tyne, in a communication to the 'Annals and Magazine of Natural History,' for August 1847, concerning the occurrence of a bird of this species not far from that town, "mentions 
his having received from Northamptonshire, nearly two years before, an egg unquestionally belonging to the Reed-Thrush," which, as appears from Yarrell, is the oldest name for this species. This egg was received from the late Mr. Wheelwright (the "Old Bushman" of the 'Field'), unaccompanied by any positive information as to where it was taken. I may mention that the said Mr. Wheelwright was formerly resident, I believe, at Cotterstock, or in that immediate neighbourhood, and that the reed-beds of our Nen in that neighbourhood are eminently suited to the habits of this species, with which I have formed a pretty intimate acquaintance in various parts of Southern Europe. There is no apparent reason for the scarcity of this species in our Islands, as it is common in Northern France, Belgium, and Holland, and it would be difficult to find a country apparently better suited to it than that part of Norfolk known as the "Broad-" district, in which, however, I do not recollect to have heard of its occurrence. 'The ReedThrush is not a bird likely to escape observation, from his incessant chattering song, which resembles that of our common Reed-Warbler (Acrocephalus streperus), but is much more powerful, and is varied with occasional croaking notes like those of the edible frog, which reptile is often found in great abundance in the haunts of this species. I believe that these birds are never found far from the reedbeds which are their favourite resorts, and amongst which it is often very difficult to obtain more than a casual glimpse of the bird as it flits chattering from one perch to another. In the early morning they come to the tops of the reeds to sing, and no one who has not visited a well-frequented haunt of this species 
would believe what a confused din can be produced by a dozen or so of Reed-'Thrushes, in concert with a sprinkling of the amphibious vocalists above mentioned. 'The nest of this bird is built of reed-tops and coarse marsh-grasses, and suspended, or rather bound, to three or four reed-stems; it is deep in proportion to its size, and is, in fact, a large edition of the nest of the Reed-Warbler. The eggs are from four to six in number, of a pale green, blotched with grey and dark greenish brown.

\section{REE D - W AR B LER.}

Acrocephalus streperus.

This bird is very abundant with us in summer, arriving generally at the end of April or early in May, and soon announcing its presence by its hurried but pleasant song, which in fine weather is heard to the greatest advantage through the night. In our district the Cuckoo appears to prefer the nests of this species as nurseries for her young to those of any other bird, and I have several times found a ReedWarbler's nest weighed down and hanging in an apparently very precarious position over the water from the weight of a well-feathered young Cuckoo. I believe that the Cuckoo in most cases carries her egg in her bill to deposit it in the chosen nest, and I have every reason to think that I once saw a Cuckoo in the act of doing so in a nest of this bird, but do not like to state it as a positive fact, as I had not found the nest in question before I observed a Cuckoo hover at it for a few seconds, and on going to see what she had been at, found a Reed-Warbler's nest 


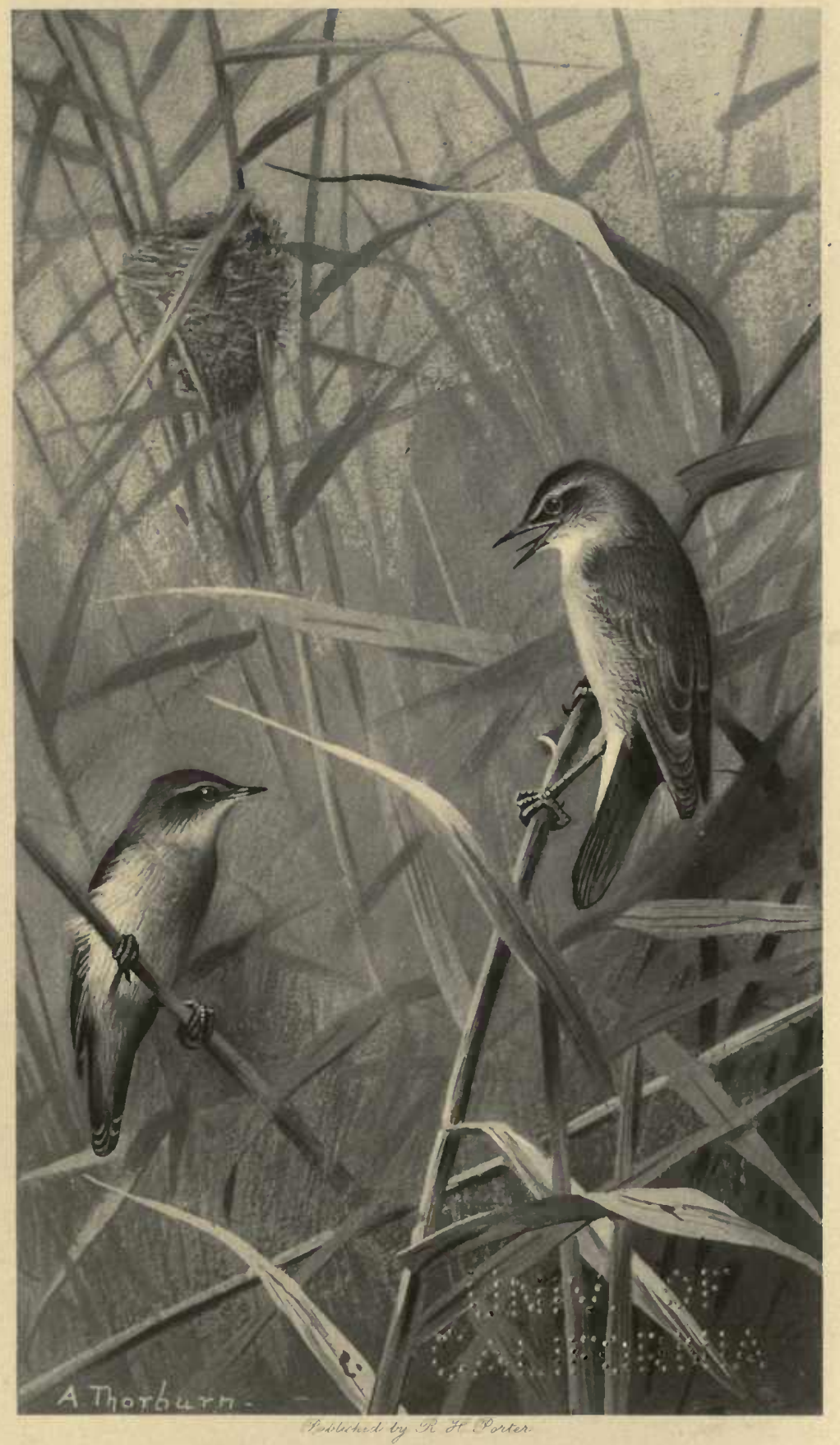

Shad Wrortutem: 


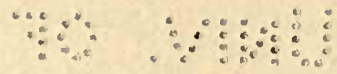

$$
\begin{aligned}
& \therefore \quad \cdots
\end{aligned}
$$


containing a Cuckoo's egg with three of those of the rightful owners.

Though our river valley cannot boast the picturesque attractions of many other English streams, it has a tranquil pastoral beauty of its own, and to any one addicted to the study of nature it presents many delights. On a balmy day in July or August a cruise on our water, besides affording the occasional chance of catching a good perch or two, is full of interest. The Waterhens leading their downy young through the mazes of water-weeds, the young broods of Wild Ducks bustling out of some reedy nook at the approach of the boat, the Kingfisher watching his prey from an overhanging spray, or darting past like a meteor, the Heron standing motionless on a favourite shallow, the incessant song and rapid motions of the Reed-and Sedge-Warblers, and the infinite variety of insects and plants, to say nothing of all the delights of home, together constitute a charm that I have seldom experienced elsewhere, and for recording it the Reed-Warbler must plead my excuse. The nest of this species is usually, but by no means always, built amongst reeds, occasionally in a bush, but, so far as my observation goes, never far from water; it much resembles in materials and shape that of the species last described, but is of course much smaller the eggs are generally five, of a dirty white, thickly spotted and blotched with greenish brown and grey. I think that this species at all events occasionally rears two broods, as I have often found nests containing fresh eggs late in August. It appears from Yarrell and other authors that the Marsh-Warbler (Acrocephalus palustris) is said to have occurred several times in England. This bird very closely 
resembles the Reed-Warbler, and may easily be mistaken for it. I must refer my readers to the fourth edition of Yarrell's 'British Birds,' vol. i. p. 374, for a detailed account of a comparison of the two species.

\section{SEDGE-WAR B LER.}

Acrocephalus phragmitis.

The Sedge-Warbler is one of our most abundant summer visitors, generally arriving about a week earlier than the Reed-Warbler, and leaving us early in September, though I have more than once met with a bird of this species on the river-banks in the winter months. The incessant chattering, varied song of the Sedge-Warbler is probably well known to most of my readers, and is often continued, as in the case of the Reed-Warbler, throughout the night; indeed, except in the fact that it is not so exclusively addicted to reeds, and its mode of nidification, its habits very much resemble those of that species. This is a restless, busy little bird, for ever flitting from place to place, setting up its hurried song as if it had only a moment to spare, crowding the notes of other birds one into another, with every now and then a break into a harsh chide and an abrupt stop. Many writers have mentioned that the Sedge-Warbler will recommence his song on a stone being thrown into the bush or sedge in which he is concealed; this I have repeatedly proved to be a fact, and I have also found that the report of a gun will set off both these birds and the Reed-Warblers in the neighbourhood into a burst of song. I have distinctly noticed imitations of 
the Reed-Warbler, Nightingale, Blackcap, and Greenfinch in the song of this bird; in fact it is often difficult to say what part of the rapid performance really constitutes the natural song of the species. Although usually found amongst sedges and thick bushes on the banks of streams and ponds, the SedgeWarbler does not confine itself to such localities, as I have met with its nest in young plantations of fir and larch far removed from water, and also in one instance in a kitchen-garden, near a pump certainly, but without any other water within a considerable distance. The nests of this species vary considerably; I have found some carefully built of moss and coarse grass externally, with a thick lining of stalks of various plants and horsehair, and others simply made of sedges loosely put together with a slight lining of hairs. The eggs are seldom more than five, sometimes six, of a yellowish white, very closely blotched and spotted with a greenish brown, and have generally a few thin wavy streaks of black at the larger end. I have several times found the nest actually on the ground, but it is more commonly slightly raised from it in a thick bush or patch of coarse sedge; a strong low bramble growing near water is with us a very favourite situation. The Cuckoo sometimes selects these nests for her eggs, but not so often as those of the Reed-Warbler. Another species of Warbler much resembling the present, viz. the Aquatic Warbler (Acrocephalus aquaticus), has occurred more than once in England, on one occasion as near to us as Loughborough, in Leicestershire, and should be looked for in the localities frequented by the Reed-and SedgeWarblers. 


\section{GRASSHOPPER WARBLER.}

\section{Locustella navia.}

As far as my personal observation has enabled ine to judge, I am inclined to consider this species as by no means common in our neighbourhood, but as it is a singularly local bird, and rarely seen without special search even in localities where it abounds, it is quite possible that it may have escaped my notice. The only specimen that I have obtained near Lilford is a young bird which was shot by one of my sons on Wigsthorpe Wolds, August 21st, 1879, and I have once, if not more often, heard its remarkable note about the same place. Mr. A. G. Elliot, of Stamford, informs me that this bird is plentiful on Barrowden Heath and Luffenham Common; in the former locality I heard $i t$, apparently in some numbers, several years ago. Although, as I have above stated, the Grasshopper Warbler is not often to be seen without special search, the singular note of the male bird soon betrays their presence; it somewhat resembles that of a cricket or grasshopper, and has gained for the bird its usual English name, but it is much more continuous, and as Yarrell, quoting John Macgillivray, truly says, "once heard can never be mistaken for the sound of those insects." In the Fen country, where this species was formerly very abundant, and in certain spots of which it is still tolerably common, it is known as "Reeler" or "Reel-bird." The only close observations of this bird which I have hitherto been able to carry out were made, in the early summer of 1856 , on a rough piece of furze and thorn-grown grazing-land adjoining Dartmoor in North Devon: 
there I found the bird very common. I should say that there must have been at least six or more pairs frequenting an area of perhaps twenty acres, but in spite of their abundance and constant song, it was only by close watching in the early morning that I was able to procure specimens for my collection; the male bird at that time will now and then creep out to the top of a furze bush "reeling" or singing, and if undisturbed perhaps remain for a minute or more, but on the slightest alarm will disappear into the thickest covert he can find, and run like a mouse through the most tangled herbage from one thicket to the next, never taking wing unless absolutely forced to do so. In vain did we search for a nest, though, armed with a bill-hook and protected by gardengloves, we plunged into masses of thorns, furze, nettles, thistles, and other defensive vegetation into which we had after patient watching traced one of these birds, tearing up the grass by handfuls, lopping away live and dead furze, on hands and knees, morning, noon, and evening; day after day we went home with perforated skins, perspiring and unsuccessful. In a very different locality, however, I once had the luck to find a nest of this bird, in my schooldays, while searching for the nest of a Waterhen. In this instance I was struggling, half wading, in an overgrown tangled wet ditch, with a strong thorn fence on one side and a sedgy bank on the other; on grasping a tuft of this sedge to steady myself, a bird fluttered out under my hand, and I was soon aware of a nest, composed entirely of sedge and grass-stalks, on the ground, and completely covered above by the tuft of sedge I have mentioned, the only apparent access for the bird being a small passage through this 
covert. 'This nest contained six eggs of a pinktinted white closely spotted with dark red, and very different from any eggs I have previously found or taken. I often revisited the spot, but could never obtain a glimpse of the birds, nor did I ever hear their note in that neighbourhood. Various authors tell us that the bird arrives about the middle of April and leaves us in September; all my own observations of the species were carried on in the month of May. We met with the Grasshopper Warbler in some abundance in the marshes near Santander, and I occasionally heard its note in the neighbourhood of Algiers. It is said to breed in almost every county of England and Wales. 'To those of my readers who live in the neighbourhood of furzy commons, I particularly recommend a search for, and, if found, a patient observation of this bird, for its habits are certainly very peculiar and little known comparatively speaking, and the discovery of a nest with eggs may justly be looked upon as an ornithological triumph. Since the above article was in print, I have heard of the discovery of several nests of this species in widely separate localities in our county.

\section{WHITETHROAT.}

Sylvia cinerea.

This well-known bird is very common in Northamptonshire, where it is commonly known as "Peggy" or Nettle-bird, though I find that Morton says that the "Reed-Sparrow," i. e. Reed-Bunting (Emberiza schoniclus), "is called Nettlemonger by some." 'The Whitethroat arrives late in April, and is to be seen 
and heard in every hedgerow or bushy spot, dodging and creeping through the twigs, now and then showing itself for an instant and disappearing with a flirt of the tail and a harsh chiding note, and again hovering with a jerky flight and hurried song in the air for a minute, and plunging perpendicularly into a bed of nettles or other shelter. The song of this bird, at its best, is a comparatively poor performance, though given forth with intense energy, and, if I may be allowed the expression, dramatic emphasis. In August the kitchen-garden at Lilford is generally full of Whitethroats, but their almost entire absence at that time in 1879 was very remarkable, more especially as I observed that several of our other summer visitors appeared there in their usual numbers, and it is difficult to imagine a cause that would so affect the present species without diminishing the numbers of birds so closely allied to it as the GardenWarbler, Blackcap, and Willow-Wren. The Whitethroat is abundant in summer in almost every country that I have visited, and occasionally winters in some parts of the South of Europe. The nest and eggs are so well known as to need no description.

\section{LESSER WHITETHROAT.}

Sylvia curruca.

'This is a less common bird with us than the last described, but cannot be considered rare; and a nest may generally be found within a very short distance of the spot where a brood was successfully reared during the previous summer. The Lesser Whitethroat arrives late in April, and remains with us, I think, as 
late, or perhaps later, than any of our summer visitors, as I sometimes notice one or more of these little birds haunting our thick fences at the end of September, and occasionally in October. The song of this species is, to my ear, much more agreeable than that of the Common Whitethroat, and is continued throughout the month of August. I believe this to be the bird, or one of the birds, to which our country people give the name of "Hay-bird" or "Hay-tit"; but this I know is a somewhat vague appellation, and is applied to several of our summer visitors. 'The present is rather a shy bird, and avoids observation, but seems to have a special affection for certain spots, in which it may be found year after year. 'The nest, a very slight structure of bents and horsehair, is generally placed near the ground, though I have found one at a height of at least five feet therefrom: a thick bramble bush is often chosen; and a very favourite locality is the thick young thorns growing on what we call the "baulk," or grassy strips of ground adjoining some of our old untrimmed fences, the said thorns growing apart from the fence in low, thick clusters, often interspersed with nettles and other summer-growth. The eggs are very peculiar, and can hardly be mistaken for those of any other British bird; the usual number is five, of a greenish white, with spots and blotches of dark brown, with, in many cases, a lighter colour underlying these blotches, and giving the egg the appearance of having been touched with a hot needle or with caustic. I find it always somewhat difficult to describe variegated eggs, as the colours, shades, spots, blotches, speckles, and streaks are often so mingled as almost to defy accurate description, and no written account of an 
egg can enable any one to identify it positively, but in this instance I have attempted to convey the impression produced on my mind by the eggs of this very beautiful little bird, which is a great favourite of mine. On their first arrival the male birds may often be heard singing from high trees, and make occasional excursions from their perches in pursuit of insects on the wing. I do not notice that these birds come into our gardens in the late summer so frequently as many other species. I have met with the Lesser Whitethroat in many parts of Southern Europe, but nowhere abundantly ; in England it is, I think, more frequent in the southern and south-eastern counties than elsewhere.

\section{GAR DEN - W A R B LER.}

\section{Sylvia hortensis.}

This bird is tolerably common with us in summer, arriving late in April, and certainly is well named Garden-Warbler, as it evinces a remarkable partiality for gardens and many of their products, such as cherries, mulberries, currants, raspberries, and peas. Yarrell mentions, on the authority of Sweet, that "this bird is very fond of the caterpillars of the common cabbage butterfly, and is the only Warbler which will eat that destructive animal." I am somewhat inclined to doubt the latter part of the above statement; but I know the former to be perfectly true, and believe that the Garden-Warbler in this way does much more good than harm to the gardener. The song of this species is some of the best birdmusic we have, and more continuous than that of many of our other songsters. I cannot call this bird 
shy, as I have had half a dozen of them within a few yards of where I sat unconcealed, but they certainly have a knack of keeping out of sight, and ten may be heard for one that is seen.

The nest of this bird, which is generally placed in thick covert, very often in a gooseberry- or currantbush, is a rather more substantial structure than that of our well-known Blackcap; the eggs, four or five in number, are often hardly to be distinguished from those of that species, which vary greatly; but, as a rule, those of the present species are the lightercoloured of the two.

This bird is very abundant throughout Southern Europe; I have met with it from Andalucia to Cyprus. In several of the Mediterranean countries it is known as "Beccafico," i.e. "Fig-picker," a name which it fully deserves; and in the autumn it is shot and caught in great number in Spain, Italy, Malta, and the Greek islands for the table, and being, at that season, exceedingly fat from an abundant fruit-diet, is a very dainty morsel. Many other small birds come under the above-mentioned designation, but the present species far surpasses any other of its congeners in flavour. In Algeria I found the Garden-Warbler very abundant in May, devoting its special attention to the young mulberries, but I could not discover that the bird breeds in that country, as it certainly does in Southern Spain. In the latter part of July and throughout August these birds throng into our kitchengardens, and are, I think, greater devourers of fruit than any of our other Warblers, though not so abundant as the Common Whitethroats or Blackcaps. I seldom see a Garden-Warbler later than the second week of September. 


\section{B L A C K CAP.}

Sylvia atricapilla.

This bird is exceedingly common in Northamptonshire, or, at all events, in our neighbourhood, though I am informed that it is by mo means frequent in the environs of Stamford. The charming song of the Blackcap, "loud and sweet," the conspicuous black head of the male bird, and its lively habits, are so well known that I imagine that most of my readers are acquainted with it as well as, or better than myself, and do not require a detailed account of its manners, song, or nest. I may, however, mention that I have seen the male bird on the nest almost as often as the female, that the bird is common almost all over Europe, and that I have now and then met with it in our county as late as December, though the great majority arrive early in April and leave us in September. In Cyprus it has long been the custom to preserve these birds in jars of the famous sweet wine of the island; and in Malta, at the period of migration, almost the entire male population turns out armed in pursuit of these and other unfortunate feathered travellers.

I find in Yarrell's 'British Birds,' 4th ed. vol. i. p. 422, the following statement concerning this species:- "The female is larger than the male, a thing very remarkable among birds of this family, measuring 6 inches and 1 quarter." The whole length of the male is given as 5 inches and 3 quarters. I have verified the above statement from a great number of specimens examined at Algiers in the autumn of 1877, where I also found a great variety in size amongst the sexes inter se. 


\section{W 00 D - W R E N. \\ Phylloscopus sibilatrix.}

With us at Lilford, this species is by no means abundant, and I could never make certain of finding its nest in my school-days, or rather holidays, in our neighbourhood, though I did stumble upon one casually now and then. So far as my experience goes of the Wood-Wren, or Wood-Warbler (as this bird is, I think, more generally called), it is fond of woods of high trees, especially of beech, beneath which there is little or no undergrowth with the exception of occasional tufts of coarse grass in the scattered spots not actually overshadowed by the spreading branches of the trees. In these and similar localities we occasionally hear, about the beginning of May, a very peculiar note, which is described by White, of Selborne, as " a sibilous grasshopper-like noise:" sibilous it certainly is, but I can perceive no resemblance in it to the cry of the grasshopper. A good description will be found in the fourth edition of Yarrell; but even this fails to convey exactly the sound produced, though I certainly am unable to improve upon it, and can only say that to my ear it has a certain resemblance to the sound of the wings of Wild Ducks when flying overhead, though, as stated by Yarrell; it begins slowly, and is more musical than any sound produced by mere muscular action can well be. This song is accompanied by a quivering of the wings, which are drooped during the performance.

The Wood-Wren is everywhere a very local bird; I never met with it anywhere in great abundance, but heard it more frequently during a few days' rambles in the New Forest, in the neighbourhood of 
Lyndhurst, in May 1866, than in any other part of England. I believe that the food of this bird consists principally, if not entirely, of insects; I do not remember to have ever noticed it in our fruit-garden at the end of summer, when other summer birds are swarming there. In common with many of its congeners and other Warblers, this species often takes insects on the wing. The nest much resembles in shape and outside materials those of the well-known Willow-Wren and Chiffchaff, but differs from them in the entire absence of feathers from the inside, being lined with fine grass and hairs. It is, I believe, always situated on the ground; those I have found were built in tufts of coarse grass, with very little apparent attempt at concealment, and contained from four to six eggs, of a pure white, closely spotted with dark red, and much resembling, except in size, those of the Chiffchaff. This bird is easily distinguished from its two more common congeners by the greener colour of the upper plumage, the pure silvery white of the lower breast and belly, and the longer wings. I can say nothing positive as to the time of departure of the Wood-Wren, as it is silent in July, and, as I have said, rather scarce with us at all times.

\section{W ILLOW - W REN.}

Phylloscopus trochilus.

This cheerful little bird is common with us as in most parts of England, generally arriving during the first week in April, and immediately announcing the fact of its arrival by its comparatively powerful and pleasant song. It is a very active bird, constantly in pursuit of the minute insects which form its principal 
food, and often taking them on the wing. It is difficult to describe the special haunts of the WillowWren, as it may be found almost everywhere; but I think it shows a decided fondness for young plantations of fir and larch. A good deal of confusion has arisen, and still exists, from the great similarity in plumage and habits of this bird to the Chiffchaff, which is also very common in Northamptonshire. The chief points of difference between the two species are the greater length of wing in the Willow-Wren, the colour of the legs, which are yellowish fleshcoloured in the present species and dark brown in the Chiffchaff, and the smaller size of this latter bird; I find in Mr. Harting's ' Handbook of British Birds' the total length of the Willow-Wren given as $5 \cdot 0$ inches, and that of the Chiffchaff as $4 \cdot 7$ inches. Besides the above distinctions I may mention those of the respective notes, the Willow-Wren possessing a sweet, loud, and somewhat prolonged song, whilst, so far as I know, the musical powers of the Chiffchaff are confined to very slight variations on its wellknown "chip-chip," which, however agreeable it may be as a signal of the returning Spring, cannot be considered otherwise than monotonous.

The nest of the Willow-Wren is generally placed on, or close to, the ground, amongst grass or low bushes, and much resembles that of the Wood-Wren, being domed, with a large irregularly-shaped entrance at the side, and composed of moss, dry grass, and, where the common bracken grows, pieces of that plant, but differs from the nest of the last-named bird in being always lined with feathers, sometimes in great profusion. In one of these nests, which I foumd in the pleasure-grounds at Lilford, the lining 
consisted almost entirely of the double feathers of the Emu (Dromceus nove-hollandice), which the builders must have carried several hundred yards, and this labour was undertaken notwithstanding the close proximity to the nest of a poultry-yard, where, one would imagine, the little birds could have supplied themselves with feathers suitable for their purpose in great variety and abundance. The eggs of the Willow-Wren are of a pure white, spotted with light rusty red, therein differing from those of the Wood-Wren and Chiffchaff, in which the spots are of dark red, inclining to purple. This bird is a common summer visitor to most parts of Europe, and winters in great abundance in the gardens of the suburbs of Algiers.

\section{C H IF F C H AF F.}

\section{Phylloscopus minor.}

The Chiffchaff so closely resembles the WillowWren that, with the exception of the distinctions pointed out in treating of the latter, an account of one will almost serve for both. 'The present species, however, arrives earlier with us than the WillowWren, and is often to be heard in the first week of March. I have twice met with this species in our district in the month of December. I think that this bird is at least as common as the Willow-Wren in such parts of our county as I am acquainted with; and its presence can hardly be overlooked by any one who pays attention to birds from its incessant cry ( $I$ cannot call it song), which is continued during the entire stay of the bird in our country. The nest 
of the Chiffchaff is hardly to be distinguished from that of the Willow-Wren, but is, I think, more often placed at some height from the ground than is the case with those of that bird; the eggs I have already described. The present species has been several times met with during the winter months in various parts of our southern counties, and is abundant at that season in many of the countries which border the Mediterranean.

\section{GOLDEN-CRESTED WREN.}

Regulus cristatus.

'This pretty little bird, which is mentioned by Morton as no less rare than beautiful, is exceedingly common in the immediate neighbourhood of Lilford, as also in many other parts of Northamptonshire. In all its habits the Goldcrest much resembles the 'Titmice, particularly in that of travelling in companies from tree to tree, and often hanging with its back downwards in its close search after inscets amongst the twigs and leaves of the evergreen trees which are its favourite haunts; it differs, however, from any of the family just mentioned in having a pleasing though feeble song. 'Though this bird is a permanent resident with us, and from its habits is much more easily observed in winter than at any other season, it appears that great numbers often arrive from abroad on our eastern coasts in October and November; this fact has been noticed by many - authors, e.g. Selby, Blyth, Gray, and others; and Mr. J. Cordeaux is quoted by the editor of the fourth edition of Yarrell's 'British Birds' as stating, 
in his work on the 'Birds of the Humber District,' that, in the portion of England of which he treats, " the autumnal migration of this species is as well established as that of the Woodcock ..... it is known as the Woodcock-pilot ...... and often alights on smacks in the North Sea, and in foggy weather perishes by hundreds."

The call-note of the Goldcrest is peculiar, and constantly repeated whilst the birds are on their excursions. In very cold weather I have found a family of perhaps a dozen of these little birds clustered together for warmth beneath the snowladen bough of an old yew tree, to the under surface of which the uppermost birds were clinging by their feet, whilst, as far as I could see, the others clung to them and to one another, so as to form a closely packed feathery ball. I happerred to notice this by chance, and, in the gloom of the overhanging boughs, thought it was an old nest, but on touching it with the end of a walking-stick, the supposed nest dissolved itself into a number of these minute creatures, who did not appear much alarmed, but dispersed themselves on the adjoining boughs, and, no doubt, soon resumed their previous formation, which I was sorry to have disturbed. Although the nests of the Goldcrest are generally placed under the branches of a yew or fir tree, we have twice found them in a thin fence at about five feet from the ground; the materials are soft moss and lichens, wool, a little grass, and a mass of small feathers by way of lining. The eggs are of a yellowish white, very closely spotted or clouded with pale rust-colour, and vary in number from six or seven to ten or more; I once found twelve in one nest. 


\section{W R EN.}

\section{Troglodytes vulgaris.}

"Jenny" Wren is so common and well known, and such a deservedly favourite bird with us, that a few words will suffice with regard to her. I cannot assign any good reason for using the feminine gender in treating of the Wren, as many of its actions and manners are essentially masculine, but I suppose that the nicknames "Cock-Robin" and "Jenny Wren" will stick to their respective owners as long as our language lasts, or, at all events, till all birds are improved (!) out of our country, and this must be my excuse for this most unscientific commencement. The Wren abounds with us and sings almost all the year round with unabated vigour, particularly on a bright frosty morning. . I have noticed that when an occupied nest of these birds is found, one or two more, apparently unfinished, may pretty certainly be discovered in the close vicinity; in the spring of 1870 I knew of thirty-four Wrens' nests in our gardens and pleasure-grounds, of which number fifteen only were eventually occupied. These nests are often used in the winter months as night refuges by little parties of Wrens, whose habit of thus clustering together in various suitable retreats has often been noticed. 'This hardy little bird braves the cold of wirter in the Highlands of Scotland, where it may be found about the banks of the mountain burns as long as they remain unfrozen. 


\section{TREE-CREEPER.}

\section{Certhin familiaris.}

This is a very common bird with us at all seasons. I find that Morton mentions it as "not unfrequent" at various places in our county, and adds, "At Desborough 'tis said to build in walls and to feed on cherries in cherry-time, and so is called the Cherrybird by some"; but continues, with discrimination, "this I look upon as a mistake; its proper food being insects." The "Tree-Creeper, although, as I have said, abundant with us, is, from its creeping habits and small size, more often to be heard than seen; the song is loud for the size of the bird, and the call-note, though low, is quite unmistakable. These little birds are always on the move, and, beginning their examination near the foot of a tall tree, will climb rapidly, by a series of jerky springs, round and round it, till they reach the upper branches, when they fly off to another tree and recommence the same operations. With a good glass the constant action of the beak in probing the crevices of the bark, and extracting and devouring the insects therein discovered, may easily be observed, though the rapidity and seeming hurry with which the search for food is carried on are marvellous. I have often seen a Tree-Creeper enter the holes pierced by Woodpeckers in our old elm trees, but I do not know that this species ever makes use of such retreats for nesting-purposes, though the sites chosen are sometimes very peculiar. I think that the favourite situation is between a semi-detached piece of bark and the trunk of a tree, but crevices in old wood-work, rough thatch, stacks of fagots, and many 
other sites might be mentioned, and we once found a nest of this bird in a bunch of dried herbs hanging from a beam in an outhouse. One of the most singular situations in which I ever met with a TreeCreeper's nest was in the foundation of a nest of the Black-Vulture in a tall pine-tree in Central Spain, and I feel certain that with us old and new Rooks' nests are used by these little birds. The nests vary much in the materials of which they are composed; twigs, moss, grasses, with a lining of feathers, are generally used, but I have known of a nest placed in a cloven willow tree, and built entirely of strong sedge, with a lining of wool, a few feathers, and thistle-down. I should put the full complement of eggs at about eight; I never found more, though I have heard and read of nine ; they are white, generally thickly spotted at the larger end with dark reddish brown. The young are very easy to rear in confinement up to a certain age, and are most amusing birds, but after some four or five months they begin to droop, and the only attempt at cure I have ever made was the opening of their prison door.

\section{N U TH A T C H.}

\section{Sitla casia.}

This bird is common and generally distributed in all suitable localities in Northamptonshire with which I am acquainted, though its numbers appear to me to vary greatly in different years, and I cannot help thinking that a certain amount of partial and irregular migration occurs with the Nuthatch, as with many other British birds which cannot be strictly classed as migratory species. This is a very lively and 
amusing bird, combining many of the characteristic habits of the Woodpeckers, the Titmice, and the Tree-Creepers. It is continually in action, creeping up and down the rough bark of our large trees in search of insect-food, or hammering with intense energy at a nut or hard seed which it has previously fixed in some suitable crevice. At Lilford, in the winter months, these birds bring great quantities of beech-mast to a certain interstice in the masonry of the porch over the front door, and are to be seen at work there almost every day from daylight till about midday. The ordinary call-note of the Nuthatch is a loud double, "twit, twit;" but at pairing-time the male has a sort of long whistle, which often breaks into a hurried twitter, and is very distinct from the note of any other of our common birds. This is a very pugnacious little bird, and I have often been much amused at watching the attacks and pursuits carried on between it and various species of the Titmouse family and the Lesser Spotted Woodpeckers, to say nothing of frequent civil or domestic squabbles between individual Nuthatches. The food of this species is very varied, consisting in summer chiefly of insects, and in autumn and winter of nuts of all sorts, fir-seeds, hips and haws, \&c., and, when it can find them, bread-crumbs and all sorts of kitchen refuse. The nest of the Nuthatch is generally situated in the hole of a hollow tree, but many exceptions to this rule are mentioned by various authors, as, for instance, a hole in a wall, and in one instance, described by Mr. Bond in the 'Zoologist' and quoted by Yarrell, " in the side of a haystack, where the mass of clay," accumulated by the birds, "weighed no less than eleven pounds, and measured thirteen 
inches by eight." In the usual case of a hole in a tree, if the Nuthatches find a nesting-place suited to their tastes, but with an opening larger than necessary, as is often the case, they set to work to plaster up the hole to the requisite size with wet clay, which soon becomes hard, and has often to be removed with a chisel before the nest can be got at. I have never met with more nest than a few scales of the bark of the Scotch fir, but leaves are very frequently used. The eggs are generally six or seven, of a rather creamy white, prettily blotched or splashed with reddish brown.

The Nuthatch is an easy bird to keep in captivity, and becomes very tame if often noticed and fed from the hand. The kernel of a hazel- or ground-nut is an irresistible morsel, and will tempt an old wildcaught Nuthatch to snatch it from the fingers very soon after capture. On one occasion I noticed two of these birds coming and going constantly to and from a certain spot in the stone balustrade which surrounds our flower-garden. As it was not in the nut-season and the Nuthatches only remained at the spot for a few seconds on each visit, I was anxious to find out in what the attraction consisted, and, on examination, discovered that they were picking out large pieces of old dry mortar or cement from between the stones, I presume for the purpose to which I have already alluded, though how they managed to moisten the material sufficiently to make it serviceable in that case I cannot imagine, as the course they both took on leaving their quarry was away from any water that I knew of, though it is not improbable that they were acquainted with some deposit on or in a large branch of a tree which would suit them. This took place in 
the early part of July, a somewhat late period of the year for these little birds to be employed in plasterwork, as I am not aware that the Nuthatch rears more than one brood.

\section{GREAT TITMOUSE.}

\section{Parus major.}

This is another very common bird in Northamptonshire, where it is often called "Blackcap" or. "Sawbird," the latter name of course being derived from its well-known notes, some of which bear a certain resemblance to the noise made in sharpening a saw. In common with all the members of this family the Great 'Titmouse is a restless noisy bird, always on the quest for food, very pugnacious, and in captivity even ferocious, often attacking any feathered companion in confinement, and in some instances of victory having been known to pick out and devour the brains of the vanquished. The nest of this bird is generally placed in a hole of a tree or wall, and is composed of a mass of moss with a lining of hair ; the eggs are white, thinly spotted with light rustcolour, and average from six to eight or nine in number. I think that this bird frequently rears a second brood, as it certainly commences nestingoperations early in April, and I have noticed young birds just able to fly more than once in the months of July and August. The Great Titmouse is common in almost all parts of Europe with which I have any acquaintance, less so in the neighbourhood of Algiers, where I found it but seldom, always in pairs, frequenting the patches of stone-pine wood in the gardens of the suburbs. 


\section{BLUE TITMOUSE. \\ Parus caruleus.}

The Blue Titmouse, or, as it is most commonly called by our country people, the "Bluecap," is more abundant with us than the species last described, and is one of the most amusing and attractive of our smaller British birds. Under the head of "Blue 'Titmouse," in Yarrell's 'British Birds,' 4th edition, will be found a far more eloquent and logical defence of this beautiful little bird against the persecution which it suffers at the hands of gardeners and others than it is in my power to write. I can only say that I am fully persuaded of the truth of the main fact therein maintained, viz. that this species is of infinitely more service than harm to the growers of fruit and flowers. I believe that the Bluecap is by nature entirely insectivorous, and have often observed that in captivity it entirely rejects hemp-seed, which the Great Titmouse seems to relish greatly. This species is exceedingly fond of scraps of meat, and we user often to observe it in considerable numbers, in the winter months, busily engaged on the horseflesh hung up near the gamekeeper's house for kennel use. When engaged in its search for food it is by no means shy, and may be closely observed, and a family of Bluecaps swinging to and fro on the waving twigs of some budding tree is, in its way, to my mind, one of the prettiest sights to be met with in our woods and gardens. The notes of this little beauty at their best hardly amount to a song, the best known being probably a harsh alarm-note, which soon brings all the birds of the species and others 
within hearing to inquire into the cause of disturbance. We have often, when watching for WoodPigeons in the plantations at evening-time, been discovered by these little Titmice, who immediately gave the alarm, and soon collected numbers of their relations and congeners, besides Blackbirds, Redbreasts, Chaffinches, and other birds, all of which seemed to consider that our attempts at concealment portended evil, as none of them would take much notice if we simply walked or loitered in the sides or shooting-paths of the coverts. The Blue Titmouse makes her nest of moss, with a lining of hair and feathers; it is generally placed in a hole in a wall or tree, most frequently, I think, in the former. The parent birds are very bold in defence of their eggs or young, and will peck and bite fiercely at fingers inquisitively introduced into their nests. The eggs are generally from six to ten in number; I have heard of as many as fifteen; they are white; thinly speckled with light rusty red. This species appears to be common in most parts of Europe; but in North Africa it is replaced by a very similar, but still more beautiful species, Parus teneriffice or ultramarinus.

\section{COAL TITMOUSE.}

\section{Parus ater.}

This bird, though common enough in our district, is decidedly less so than either of the two species last mentioned, to which, in general habits, it bears a great resemblance. I find that Yarrell says that it is more vegetarian in its diet than either the Great or Blue 'litmouse, and I have often remarked its 
peculiar partiality for fir-seeds, and consequently for fir-woods, which are comparatively scarce in our part of the county. The note of the Coal-Tit differs considerably from that of the other British species of the family, and has no merit as a musical performance. Most of the nests of this bird which I have examined in situ have been placed actually

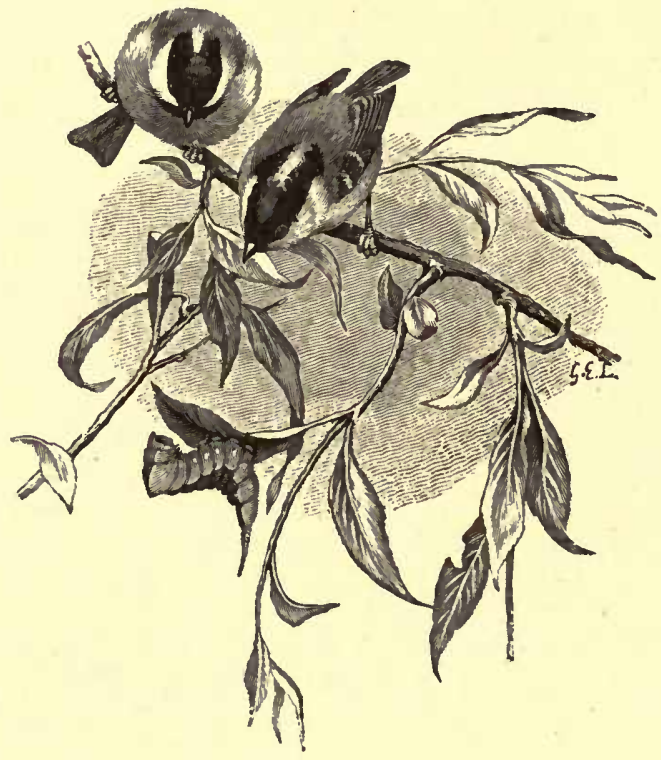

Coal-Tits in doubt.

underground in the burrows of rabbits, moles, or mice; but it will sometimes make use of an old wall or a low decayed tree-stump for a breeding-site ; and $I$ have heard of an instance in which a pair of Coal-Tits began a nest in one of a heap of drainingtiles which had been left for some time undisturbed. The nests which I have found were composed of moss, wool, feathers, and hair; in one instance the 
latter material seemed to have been entirely taken from the bellies of the Fallow-deer, and I have several times seen a quantity of rabbit's fur used as a lining. The eggrs are generally six or seven, and very closely resemble those of the Blue Titmouse.

Since the above article first appeared in print, the Coal-Tit has become exceedingly common about Lilford, and is at present (1894) at least as abundant as any other species of the genus Parus.

\section{M A R S H- T I T M O U SE.}

\section{Parus palustris.}

This species, though it cannot be called rare, is certainly the least frequent of the five common British species of Titmouse in our neighbourhood, though we can generally find a pair or two of MarshTits within a quarter of an hour's stroll from the house at Lilford, the old alders by the river-side being an almost sure find for these little birds at all seasons of the year. So far as my observation goes, the Marsh-Tit is not such a frequenter of gardens or the vicinity of human habitations as the three preceding species, and is less often to be found amongst high trees than those birds, though in other respects it closely resembles them. The note is harsh and peculiar, and has often guided us towards the nest, which is generally built low in a rotten stump.or an old pollard willow. Both nest and eggs may easily be mistaken for those of the more common Coal-Tit, but the present species sometimes makes use of willow-down as a lining, and, so far as I know, never 
employs feathers for that purpose. The eggs are from five to seven or eight in number. The MarshTitmouse is by no means abundant in any part of the continent of Europe which I have visited, and in Spain was found by us in the province of Santander only.

\section{LONG-TAILED TITMOUSE.}

\section{-Acredula caudata.}

This Titmouse, though not more abundant in Northamptonshire than in many other parts of England, is, I think, one of the best known of our small birds, and the nest of the "Pudding-Bag," "PuddingPoke," or "Bottle-Tit," by all three of which names it is commonly known to our country-people, is often to be seen hung up as an ornament in our cottages. Few days occur, after the fall of the leaf, upon which I cannot make sure of finding this and the four species last described without much search, and, in the autumn and winter, where one of this species is found it is pretty certain that more are not far off, as the "Bottle-Tit" generally travels in family parties, which follow their leader from tree to tree with an undulating flight and constant twittering note, and on alighting immediately begin a close investigation of the smaller branches and twigs for insects. On a warm sunny day in early spring the old whitethorn bushes near the house at Lilford are sometimes alive with our five species of Titmouse, besides Goldencrested Wrens, Tree-Creepers, Nuthatches, and other birds, and with a little caution all these may be 


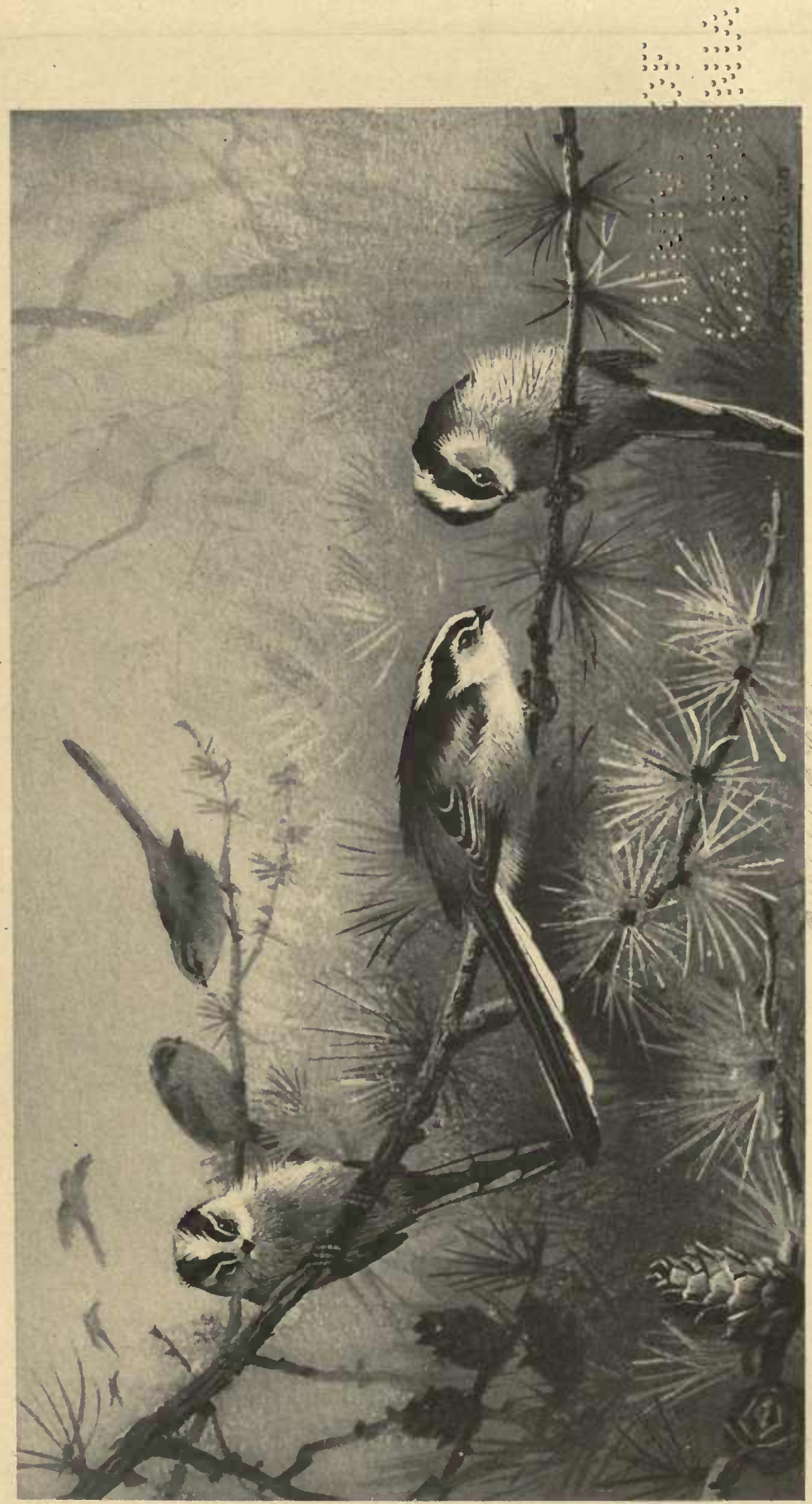




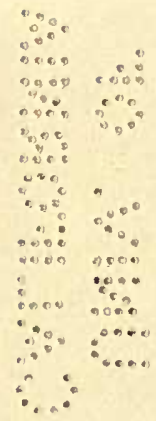


closely observed. I am not aware that the Longtailed Titmouse possesses any song or notes other than those above mentioned; in fact, none of the birds of this family are remarkable for their musical powers, though many of them are noisy enough. This little bird has the same habit as the Golden-crested Wren of huddling together in clusters, composed of many individuals, under the branches of some thick evergreen tree in severe weather. I have met with and heard of many such instances in our neighbourhood. On one occasion I saw one of these birds enter a Woodpecker's hole, but, on examination, found that there was no appearance of any nest therein, and can only suppose that the visit was prompted by curiosity. The wonderful nest of this species is so well known, and has been so often described, that I shall not enter into any particulars concerning it, except to say that, although it is generally placed in the middle of a thick thorn-bush in our old fences, we once found one swinging with every gust of wind in the leafy extremity of a straggling elder-bush overhanging a path in one of the plantations at Lilford. The greatest number of eggs we have ever met was eleven, but the average number is about seven; their usual colour is white, with faint markings of pale rusty red, but many instances have come under our notice in which they were pure white. These birds frequently use their nests as roosting-places in autumn and winter. 


\section{BEARDED TITMOUSE.}

\section{Panurus biarmicus.}

I am not aware that any instance of the occurrence of this bird in our county has hitherto been recorded, though it was in former years pretty common amongst the vast reed-beds which fringed Whittlesea Mere in the closely adjoining county of Huntingdon. I should hardly, however, consider myself justified in admitting it into this list solely on that ground, but do so from the fact that on one occasion I heard its unmistakable call in a small patch of reeds on the left bank of the Nen at a short distance below Lilford. This happened in the month of September certainly, of the year I do not feel quite sure, but it must have been either 1848 or 1849. I had never previously heard the note, and was entirely puzzled; I was alone in a boat, and though I attempted, after waiting a considerable time, to get a sight of the unknown bird by forcing it to take flight, I could not succeed in so doing, and it was only after an interval of some years that I again heard the same notes amongst the Broads of East Norfolk, and found that they proceeded from a party of "Reed-Pheasants," as these birds are called in that district. 'There could be no mistake about it; my unknown bird was undoubtedly a Bearded Titmouse, nor was there anything extraordinary in the fact of his presence in the spot mentioned, as the species is given to autumnal wanderings, and Whittlesea Mere is within a very moderate distance as a bird flies, with many opportunities for rest by the way. I can say but very little of the habits of these birds in a wild state, having only met with a few now and 
then in East Norfolk when we were in pursuit of wild fowl during the winter months. They appeared to keep in small parties, and gave forth a constant ringing bell-like call, very peculiar and very musical: they were not very shy, and on one occasion, whilst lying hidden in a reed-bed for a shot at some wild fowl, I had eight or nine of these graceful little birds close around me for several minutes; they climbed rapidly up the reeds, examined the heads of the plants, and constantly darted down to the ground, or rather crust, from which the said reeds were growing, to recommence operations on other stems. Their actions much resemble those of the true Titmice, from which in many other respects, such as internal structure, nesting-habits, coloration of eggs, and voice, they differ very widely. I have never seen a nest of this species in situ, but received a beautiful specimen thereof some years ago from Holland: this nest is built almost entirely of the leaves of the common reed, with a few blades of fine sedge, and lined with the soft tops of the former plant; the eggs in this instance were six, of a pure white, speckled and irregularly streaked with dark brown.

The Bearded Titmouse is still to be found in some numbers in certain spots in East Anglia, though many of its former haunts are no longer suitable to its habits, from the effects of draining and cultivation. The chief food of this species appears to be the seed of the reed, but in captivity I have found them most omnivorous, and ants' eggs were very favourite morsels with them, as they are with almost every cage-bird with which I have any acquaintance. My living specimens of this species were purchased in London, and were said to have been sent thither from the 
Netherlands; they became very tame, and are very engaging pets, in motion the whole day long, often hanging head downwards from the top of their cage, and crowding together closely at dusk on the same perch. I found this species in Albania, but have not met with it elsewhere out of England, though it is not uncommon in several parts of Europe, and is well known in one or two localities in the east of Spain. From the nature of its usual haunts, the Bearded Titmouse during the summer months is much more often to be heard than seen, and its note once heard can never be mistaken for that of any other European bird.

\section{W A X W I N G.}

Ampelis garrulus.

Of this beautiful bird in its wild state I know nothing from personal observation, and therefore cannot do better than recommend those who may be interested in its habits to read the article headed "Waxwing" in the fourth edition of Yarrell's 'British Birds.' A winter seldom passes without a record of the occurrence of this species in some part of England, most frequently in the eastern counties; and on several occasions it has visited our Islands in very large numbers: in the winter of 1849-50, for instance, "it appears that 586 examples were recorded in the 'Zoologist' as occurring between November and March, nearly half of them in the second and third weeks of January." Perhaps the most remarkable fact with regard to the Waxwing is that, although the bird had been known in this country and in most 
parts of Northern and Central Europe for at least two centuries, it was only as an uncertain winter visitor, and till the year 1856 its manner of nesting, colour of eggs, \&c. were matters of profound mystery. In that year, however, the secret was discovered through the indefatigable exertions of the late $\mathrm{Mr}$. John Wolley in Lapland, a condensed account of

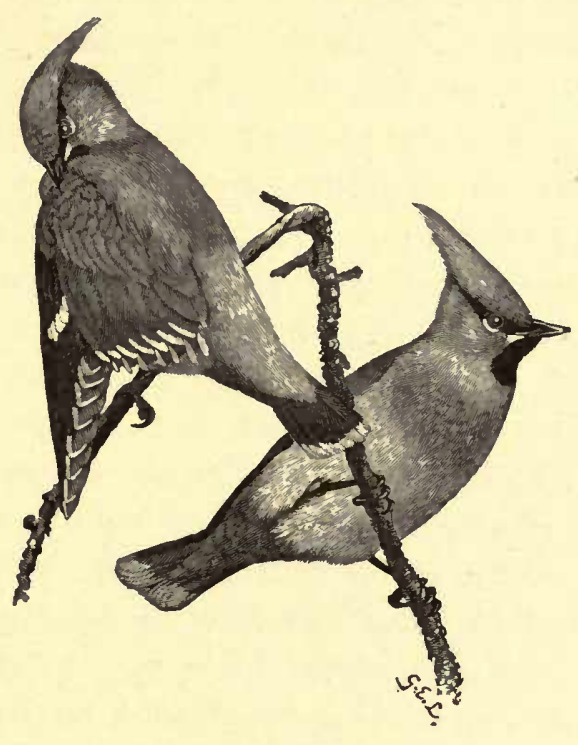

Distinguished Foreigners.

whose most interesting discovery will be found in Yarrell (loc. sup. cit.), and full details are given in 'The Ibis' for 1861 (pp. 92-106).

The Waxwing has occurred several times to my knowledge in our county and on its borders. Three were obtained near Thurning in or about 1838; one of these birds was preserved, and was for a long time in the possession of a relation of mine, to whom it was brought "in the flesh." In the winter afore- 
mentioned of 1849-50 several of these birds were shot in the neighbourhood of Peterborough, one of these (a very fine old male) is now in my collection. Mr. A. G. Elliot, of Stamford, has informed me that several were killed in Stamford open field in 1844-45; and the Rev. R. S. Baker, of Hargrave, in a letter dated February 15, 1876, writes that "the Waxwing has been shot in this village some years back." Besides these instances I may mention that on December 3, 1875, we heard the chatter of a party of Waxwings passing overhead whilst we were inspecting my aviary in the pleasuregrounds at Lilford; the air was full of snow, and we could not see the birds, though they seemed to be at no great distance. I must add that I am well acquainted with the note of the Waxwing from having kept many of them in confinement, a proceeding which I cannot recommend, as they have no merit whatever except their beauty, being dull, quarrelsome, greedy, and filthy to an incredible degree, and in most instances dying from plethora after a short captivity. Hips and haws, currants, raisins (in fact, small fruits of all kinds) are voraciously devoured by these birds, and appear to be their favourite food, but they will also eat chopped meat, hard-boiled egg, hemp-seed, bread-crumbs, carrots, potatoes, and ants' eggs ; they drink a great deal, but seldom wash, and I have more than once seen a Waxwing deliberately eat its own fæces, though it was abundantly supplied with many varieties of food; none of these birds ever became tame with me, and I shall certainly never buy any of them again. I have no doubt that a great many more instances of the occurrence of this species in Northamptonshire have taken place than those I have mentioned above; 
the abundance of winter berries in most parts of the county ought to attract them, but, as I have before said, ornithological records are lamentably wanting amongst us, and I feel convinced that our list of Northamptonshire birds might be increased, on excellent authority, by at least fifty species, if only a few of those persons who possess some knowledge of ornithology would take the trouble to keep careful notes, and publish their observations, with the exact dates and localities, of any unusual occurrences. I do not, of course, expect that our list of birds can ever rival those of the eastern counties, but I earnestly wish to rouse the emulation of our native naturalists in this respect.

Since the above article was written, two other perfectly well authenticated occurrences of the Waxwing in our county have come to my knowledge; the first of these was a specimen observed at a short distance by Mr. Ed. Skrimshire in his garden at Stoke Doyle on January 13, 1887, and the second, apparently a solitary female, was seen by the Rev. H. H. and Mrs. Slater at a very short distance from them, near Ditchford Bridge, on February 3rd, 1590. I have recorded these occurrences in the 'Zoologist' under the respective dates given above.

\section{PIED WAGTAIL.}

\section{Motacilla yarrellii.}

This species, better known to our country-people as "Dish-washer," is very common with us from February till the end of September, when its numbers very sensibly decrease, and in the frequent event of a severe frost very few of these pretty birds remain in our neighbourhood, though now and then a Wag- 
tail or two may be found, even in the hardest weather, attending the sheep which are at that season penned upon turnip-lands. In the summer months it would be difficult to say where the Pied Wagtails may not be met with in this county: our meadows, lawns, grass-plots, and road-sides are alive with them, but they avoid woods, and generally prefer somewhat moist grounds and the neighbourhood of waters; they may be seen, however, in almost any field in which horses, cattle, or sheep are pastured, dodging about amongst the legs of these animals in pursuit of insects. 'The nest of this species is often chosen by the Cuckoo, whose egg generally resembles those of the Pied Wagtail perhaps more than those of any other of our common insectivorous birds. At Lilford we almost every year have one of these intruders reared by a pair of Wagtails in the flower-garden, and it is amusing, though somewhat pitiful, to watch the trouble and anxiety of the deluded foster-parents to feed and protect their ungainly and ravenous ward after it has left the nest. In one case the Wagtail's nest was built in ivy on the garden-wall within a few feet of several trained Falcons on their blocks, and the young Cuckoo, on its first sally from the nest, in trying to reach a stone balustrade fell within a few inches of one of the former birds, which, fortunately, was at that moment hooded; the distress of the old Wagtails was really painful to see, though they themselves would constantly run amongst the Falcons, whether hooded or not; they evidently were in the greatest terror for the safety of their treasure, which sat chirping and gaping for food, whilst the Wagtails fluttered over it, settled close to it, darted at the Falcon, and almost screamed in their agony of anxiety. I caught the Cuckoo and placed it on the balustrade, 


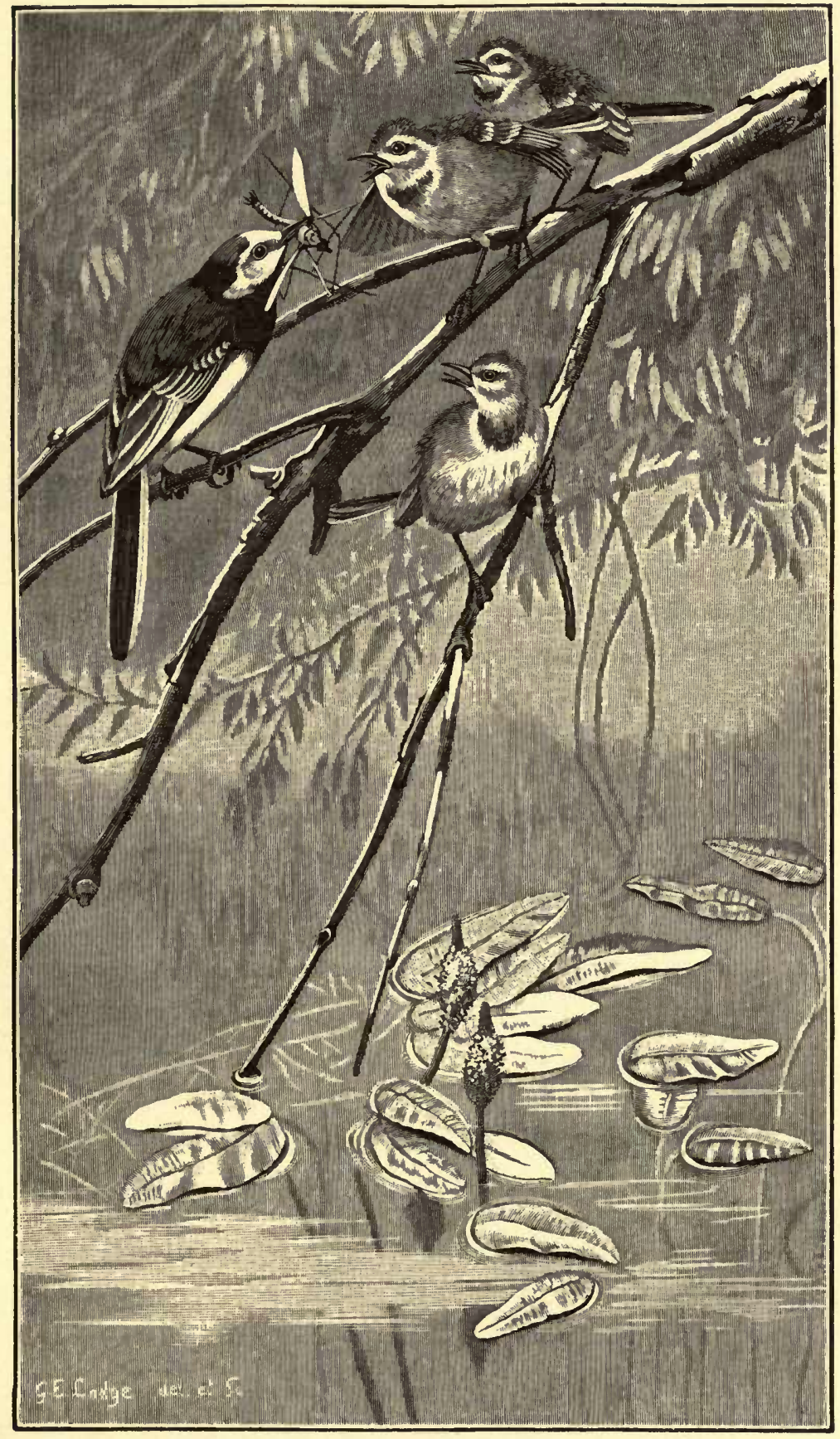

Pied Wagtail and Brood. 
where it was fed almost incessantly for upwards of an hour by its guardians, one or other of which, however, was never out of sight of the voracious fledgling. A very favourite spot for the Pied Wagtail is a ford or shallow whereat cattle come to drink and bathe; in such places this species may often be seen wading in the water, snapping at the insects which hover around, or searching the bottom for minute larvæ; it has been observed also to take minnows from a fountain. This bird generally selects a hole in the side or at the top of a wall, especially when overgrown with ivy, for a nesting-place; but I have known many instances in which the nest has been placed on the ground, in thatch, rock-work, the top of a water-pipe, a fagot-stack, and once or twice in a large flower-vase in our garden; I once only found a nest of this bird in a bush, and believe that such instances are very uncommon. The materials used for the nest are moss, grass-stalks, and fine roots, with a lining of hair; the eggs are from four to six, white, with a close sprinkling of grey. It is remarkable that a bird so common as the Pied Wagtail is in our Islands should be comparatively rare on the continent of Europe, where its place is taken by a very closely resembling race, the so-called White Wagtail (Motacilla alba), which is a tolerably common vernal-visitor to this country, and has been clearly identified in Northamptonshire at least once by Mr. W. J. Horn, near Kingsthorpe, on April 30, 1892, is recorded as having occurred several times in Lincolnshire, and has been found nesting as near to our borders as Whittlesea. These two forms are easily distinguishable in adult summer plumage, but in winter and immature plumage may easily be confounded. 


\section{GREY WAGTAIL.}

\section{Motacilla sulphurea.}

This extremely pretty bird is by no means abundant with us, but may, nevertheless, be met with in pairs in the winter in certain spots year after year. We generally find it frequenting shallow gravelly bends of the river or brooks, over which the water runs swiftly, and which consequently remain longer unfrozen than the more tranquil reaches of our streams. A pair often select the neighbourhood of our boathouse at Lilford in severe weather, and make frequent visits to the old stonework of the house. I think I may say that these birds rarely perch upon a tree or bush. 'The favourite haunts of this Wagtail in our Islands are the wilder portions of our western and northern counties, where it may be met with, in the company of the Dipper, frequenting rapid rocky streams, about which it is constantly flitting from stone to stone, or running over the pebbly banks in pursuit of its insect-food: on such streams an old watermill is almost a certain find for a pair of these birds in the nesting-season, and in holes in the walls of such buildings or their appurtenances I have found their nests in Devonshire, North and South Wales, Derbyshire, various parts of Ireland and Scotland, Spain and Switzerland. In the eastern and midland counties of England this Wagtail is seldom seen in the summer months, and is not, so far as I know, numerous in winter-in fact, I do not recollect ever to have seen more than half a dozen of these birds together in any part of England. The note of the Grey Wagtail is of the same character as that of the species last described, but sharper and clearer in 
sound; I am not aware that the male bird has any true song. I have not examined the stomachs of any of this species, but their principal food evidently consists of insects, varied, according to Yarrell, by small freshwater mollusks. 'The nest, usually placed in a hole of a wall or in a stony bank, much resembles that of the Pied Wagtail, but is considerably smaller. The eggs are usually five in number, of a creamy white, closely blotched or clouded with pale yellowish brown, and may be distinguished from those of the commoner Yellow Wagtail (Motacilla rayi) by their larger size and the absence of the hair-like dark streaks which in most cases are found on the eggs of the latter bird. I do not recollect to have seen the Grey Wagtail in Northamptonshire earlier than about the middle of September or later than the end of March. I may mention that our country-people confuse this species with the Yellow Wagtail, and generally call the young Pied Wagtail "Grey Dishwasher."

\section{YELLOW WAGTAIL. \\ Motacilla rayi.}

This bird, which is a very common summer visitor to many parts of England, cannot be called abundant in our neighbourhood; it arrives in small numbers about the beginning of April, and from that time till the middle or latter end of September a pair may be found here and there, generally haunting a rough fallow-field or badly-drained pasture-land. 'This species is much more arboreal in its habits than the two birds last described, and may often be seen perched on a low bush or fence. The nest is built 
on the ground, of dried grass-stalks and fine roots with a lining of hair, and is generally placed in a tuft of grass, or in a slight depression well concealed by summer plants. The eggs are generally five, sometimes six, in number, and much resemble those of the last species except in the particulars already mentioned. About the middle of September we generally notice small parties of these birds in our meadows and pastures, evidently bound on their southward migration; they are exceedingly local birds, and their appearance may safely be reckoned upon, year after year, in the same localities at the same date. The Yellow Wagtail has more of a song and altogether more musical notes than either the Pied or Grey species. Yarrell states that this bird is generally rare in Ireland, but we found it breeding on the shores of Lough Corrib, co. Galway, in the summer of 1854 .

\section{TREE-PIPIT.}

\section{Anthus arboreus.}

This bird, which is, I think, generally known in Northamptonshire as "Titlark," is a common spring visitor to our district, though not perhaps so abundant there as in many parts of England. It arrives with us generally in the second or third week of April, and the male bird soon makes his presence known by his loud song, which has some resemblance to both that of the Canary and the Sky-Lark; he also attracts attention by his common habit of soaring from a tree to a moderate height, and descending slowly, singing his best, with tail outspread and legs hanging, to the perch from which he started, or 
another close by it, without coming to the ground: this habit has, in some places, gained him the name of "Wood-Lark"; but I need hardly say that the true Wood-Lark (Alauda arborea) is a very distinct bird, which differs from the present species in many essential particulars, and whose song is in every way far superior to that of the Tree-Pipit. This bird is very active on the ground, and runs swiftly and lightly, in the manner of a Wagtail, in pursuit of insects, which, with rare exceptions, seem to be its only food. In common with a great many of our spring visitors, this Pipit is a very local bird, generally to be found at or about the same spot year after year. There is on the lawn at Lilford a certain oak tree, standing alone, not far from the river, in or about which tree I have never failed to find a pair of these birds for as far back as I can remember, and within a few yards of which I have often found their nest placed on the ground amongst tall grass, and built of moss and dry grass-stalks with a lining of dark hairs. The eggs are generally five in number, and vary very much in different nests, though all the varieties possess a certain indescribable character, which, to a practised birds'nester, would, I think, prevent their being mistaken for those of any other British bird. In the case of the nest or nests above mentioned, I have generally found eggs of a white ground-colour which is nearly hidden by broad streaks and blotches of very dark brown, in others pink is the predominant colour, but I cannot do better than refer my readers to the fourth edition of Yarrell's 'British Birds,' vol. i. p. 572, for a clear description of the "three or four groups" into which a series of the eggs of this bird may be divided. The Tree-Pipit, besides singing on his 
aerial excursions, as above described, often sings from his perch, and though his actual strain of melody is not very prolonged, it is as often repeated as that of any singing bird with which I am acquainted. This species may be met with in small, probably family, parties about the end of August and leaves us early in September. The nest of this bird is often used by the Cuckoo, but we have only met with two such cases in Northamptonshire.

\section{MEAD OW-PIPIT.}

Anthus pratensis.

This species, commonly known as Titlark in those parts of England in which it breeds, is, in our neigllbourhood, an autumnal visitor, and not very abundant at any time, no doubt from the lack of the open wastes and commons in which it chiefly delights. I cannot positively say that it does not breed with us, but I certainly never found a nest in my boyish birds'nesting rambles in our district, nor do I recollect to have met with the bird in the summer months. About the middle of September the Meadow-Pipit appears in numbers in our pastures and meadows, and some may generally be found throughout the winter by the side of the river or its tributary brooks; the greatest numbers I have met with have always been in these localities in the month of March, but their stay is then very short. Although with us, and in other parts of England, this bird is migratory, in many places it remains the whole year, only shifting its quarters, according to weather and "questions of supply," from one spot to another. In many of the upland moor-districts of our Islands the Meadow-Pipit 
is decidedly the most common of small birds, and is found, more or less abundantly, in suitable localities from the Land's End to Shetland; it is also exceedingly common in Ireland. Though in many habits it resembles the Tree-Pipit, this bird is seldom seen to perch on a tree; its notes are much softer, and its favourite nesting-haunts very different from those of that species, besides which the Meadow-Pipit is not so exclusively insectivorous, and often varies its diet with various seeds. The only bird of this species which I ever kept in captivity lived for upwards of a year almost entirely on canary-seed, with now and then a few ants' eggs. We have found the abundance of this little bird in a wild district of Inverness-shire a great hindrance in deer-stalking, as it would rise close to us as we were creeping up to a stag, and going off with a jerky flight and cry of alarm, put all the hinds at once on the alert. The nest of the Meadow-Pipit resembles the inner part of that of the last species, but this bird seldom makes use of moss. The eggs are five or six in number, and vary a good deal in colour, though not so much as those of the Tree-Pipit; the most common type is of a yellowishwhite ground, closely spotted and blotched with greyish brown. The nest, in every instance that I have met with, has been placed on the ground, in a tuft of grass or heather or closely cropped furze, always far away from anything worthy of the name of a wood, and seldom even very near to any high trees. On the moorlands and open commons, the nests of this bird are the favourite nurseries of the Cuckoo, and in those localities one or more Meadow-Pipits may constantly be seen in pursuit of an intruder of that species, against whom they seem to display a special animosity. 


\section{RICHARD'S PIPIT.}

Anthus richardi.

Mr. William Seal, an experienced bird-catcher, has repeatedly, and very recently (October 1894), assured me that he clearly identified two of this species near Thorpe Waterville whilst plying his business there on October 26, 1883. Seal is perfectly well acquainted with this Pipit, of which he has captured more than one in his nets, and is quite positive from the note and flight of these two birds that he could not be mistaken. I am convinced of his bona fides, but think it possible that he may have been deceived by the appearance of the Tawny Pipit (Anthus campestris), with which he is not acquainted. I have no personal acquaintance with Richard's Pipit in life, but have very frequently met with the Tawny Pipit in Spain. Both of these species are accidental and uncommon stragglers to this country, and, roughly speaking, much resemble each other, though Richard's Pipit is considerably the larger of the two.

\section{SKY - LARK. \\ Alauda arvensis.}

A detailed account of this well-known bird, its song and habits, would, I think, be entirely unnecessary here, as there is probably not one of my readers who is not already acquainted with them. I find that with us the numbers of this bird are, and for some years past have been, perceptibly decreasing, and though in the winter months, especially after the break-up of a long and severe frost, vast flocks may 
be still occasionally met with on our arable lands, I think that I may safely say that on our freshly cut stubbles in September not a tenth part of the SkyLarks which used to frequent them twenty years ago are now to be met with. There is no doubt that this species and many others suffered severely some years ago from the abominable practice of scattering poison amongst the newly sown wheat, but not to a sufficient extent to account, at all events in our district, for the steady and permanent annual decrease above mentioned. It is true that enormous numbers of Sky-Larks are netted every year in this country and on the continent, but this has been the case for many more years than we can recollect; no natural causes, so far as I am aware, have conduced to this diminution, and the Sky-Lark is certainly not a species which is injuriously affected by the improvements in agriculture, draining, enclosures, and the like, so that I confess myself at a loss to assign any probable cause for this very certain fact. I am not by any means forgetful of the damage done to all ground-breeding birds by mowing-machines and similar implements, but as the majority of our Sky-Larks certainly nest on the arable land, and their young can generally take care of themselves by the time of corn-harvest, they are not so much affected by these inventions as are our game-birds, which are more addicted to nesting in grass-fields and meadows, and are cut to pieces and mangled by dozens, from the want of a little care in the management of these, to the sportsman, infermal machines.

The Sky-Lark may be correctly termed migratory in our Islands, for although great numbers nest in most parts of Great Britain and Ireland, a very large 
portion of our home-bred birds leave us in the autumn, and our shores are annually visited at that season by flocks of foreigners, whose stay depends on the weather. In our own district I have often noticed streams of Sky-Larks passing over at a moderate height, and in almost complete silence, towards the end of October; these birds seem seldom to alight, and I have generally observed that their appearance in this manner is an infallible sign of the approach of severe weather. $V$ ast numbers of this species are caught by dragging the stubble at night with nets and in many other ways, and many are also shot by the aid of Larkglasses, the glittering of pieces of looking-glass in the sun seeming to possess a fatal fascination for these birds whilst migrating, though I have in vain tried to attract our resident birds in that manner. These birds are most excellent food when fat, and meet with a ready sale in all parts of Europe.

In all parts of the Mediterranean shores, especially in Italy and Sicily, the autumnal migration of the Sky-Lark is looked forward to with immense anxiety, and tens of thousands are annually shot and caught in those countries. We happened, in the beginning of November 1856, to be sailing from Cagliari to $\mathrm{Pa}$ lermo, against fresh southerly breezes, and during the voyage, which occupied the best part of three days, we were constantly surrounded by myriads of tired Sky-Larks, many of which came on board. On our arrival at our port we found the greater part of the male population up in arms, not, as usual, against the government, but for the slaughter of these poor birds, which were dropping about, worn out by their journey, not only along the sea-beach, but on the quays, wharves, public gardens, and even in the streets 
of the town; many were caught by hand or knocked over by sticks and stones, but along the "Marina," or marine promenade, a constant discharge of smallarms was kept up from daylight to dark during the few days of our stay.

The Sky-Lark is much given to dusting itself, but, contrary to the habits of most birds which indulge in that luxury, is also fond of bathing. This bird, as is well known, will live and sing for many years in captivity if properly cared for, and has been even known to breed in confinement.

The Sky-Lark affords very good sport to the falconer, the Merlin being the bird selected for this pursuit; but the best trained of these little Falcons rarely manage to take an adult Lark in full feather, though they will easily master young or moulting birds in August and the early part of September. I have alluded, when treating of the Hobby, to the ancient manner of taking Larks with the aid of that species. Curious stories are related of the removal by SkyLarks of their eggs and young from exposed and dangerous sites, or when their nests have been interfered with, and Yarrell quotes an instance in which the parent birds built a dome of grass over a nest containing young, which had been laid bare by the scythe. The principal food of the Sky-Lark appears to be seeds of various kinds, varied wiih swuall worms and insects, and in the winter it is fond of young corn, turnip-tops, and, in fact, almost any green food that it can find. 
72. W $00 \mathrm{D}$ - LAR K.

Alauda arborea.

This bird is by no means common in our neighbourhood, or, indeed, in any part of Northamptonshire with which I am acquainted, and although I have met with it in the county, I could never make sure of finding it at any particular spot, or any special season of the year. I hold the song of the WoodLark as second only to that of the Nightingale amongst our British birds, and a very close second; indeed there is less variety of excellence in the musical powers of the former than those of the latter: we never heard a song of a wild Wood-Lark that was not perfect melody, whilst we have listened to many Nightingales whose strains were unworthy of their name. The Wood-Lark in plumage much resembles the Sky-Lark, but it is a smaller bird, with a comparatively short tail, and may always be distinguished by the light-coloured streak over the eye; its habits also are very different from those of the latter bird, as, with a few exceptions, it is found in the neighbourhood of trees, and, as I have observed, is very fond of small clearings in thick woods or plantations; but it is a species of which I have seen very little in this country, and of whose habits I have observed most in Central Spain. In England it appears to be a partial and irregular migrant, leaving its breeding-quarters in winter, to appear at that season in districts where it is comparatively unknown in summer, and vice versâ, but this habit is not with. out exceptions, as it seems that in some localities the Wood-Lark is a permanentresident. This bird soars and sings on the wing in the same manner as the 
Sky-Lark, but may also often be heard in full song from its perch on a high tree. It is said to sing at night in the summer months, but we have listened in vain for its music after dark, though its vocal powers seem to be at their best in the "gloaming," when few birds but Owls and Nightingales are to be heard. In Spain we have generally met with the Wood-Lark in early spring, frequenting dry localities amongst the woods of cork and evergreen oaks, in spots where the undergrowth of heath, cistus, \&c. is low and the ground comparatively bare; at that season it is found in small parties of from six to ten, which, on being approached, fly off with a soft musical call and wavering flight, to alight again at a short distance, some on the ground and others in the neighbouring trees; on a second alarm they generally make off together over the trees to a distance. I have never met with the Wood-Lark in what could be called open country. On the ground this bird is very active, running swiftly in every direction in pursuit of the small insects which seem to constitute its principal food; on catching sight of a human looker-on, the Wood-Lark will often squat close to the ground, especially if its eye has caught that of the observer, and in such cases will allow of a very close approach. I note that the editor of the fourth edition of Yarrell's 'British Birds' states that the first eggs of this species are often laid by the middle of March in this country, but I think I may safely say that in Central Spain the Wood-Lark has rarely paired at that season. The very few nests I have met with contained fresh eggs about the beginning of May; these, of course, may hare belonged to a second clutch; but I do not think that can have been the case, as I had noticed 
the birds in small flocks, as above mentioned, as late as the second week in April. I may, however, mention that these nests were in a district at least two thousand feet above the level of the sea. In one instance I discovered the nest by startling the parent bird from it with a cut from my stick at a viper, which lay coiled up within a foot of her as she sat. The nest in this case was entirely composed of dry grass-stalks, the finer of which formed the lining, and contained four eggs, of a yellowish white, closely spotted with light brownish lilac, the markings being almost confluent at the larger end. Mr. A. G. Elliot, of Stamford, informs me that he is acquainted with a certain spot in North Northamptonshire in which a pair of Wood-Larks may generally be found during the breeding-season. 'This bird is not mentioned by Morton.

The only occurrence of this species in Northamptonshire that has come to my knowledge since the above article appeared in our county Nat. History Journal, was communicated to me by the Rev. Henry H. Slater, who informed me that he heard, and clearly identified, a Wood-Lark singing in the Bedford Purlieus near 'Thornhaugh, on April 24th, 1893.

\section{S N O W - B U N T I N G.}

\section{Plectrophanes nivalis.}

I find at p. 427 of Morton's 'Nat. Hist. of Northamptonshire,' "The greater py'd Brambling, or Mountain Finch (Montifringilla calcaribus alaudæ major). Two of these were taken in Brixworth Field in November 1708. 'They were catch'd in the common 
Lark-nets together with the Field-Larks; they readily playing about the Looking-Glass Stale in the manner of Larks. Since that I have seen them at least 20 in a flock, in our fields about Oxendon, together with the lesser py'd Brambling, as has been noted above." I have no doubt that the above refers to the SnowBunting, though I must confess that our author's "cut" of the Lesser "py'd Brambling," save in the matter of the long hind claw, bears as much resemblance to the present species as to the Brambling (Fringilla montifiringilla), which bird it is, I believe, intended to represent. In a list of birds of the neighbourhood of Stamford, supplied by Mr. A. G. Elliot, whom I have often previously quoted, I find "Snow-Bunting, only a few," without dates or particulars of any sort. Besides the above, the only notices I have of this bird as occurring in Northamptonshire are contained in letters from Lady Mary Thompson and the Rev. R. S. Baker, the former of whom informs me that one of these birds, "in its snowy plumage," was shot by Mr. Henderson near Milton, about 1822-23, whilst Mr. Baker simply says, "Snow-Bunting seen near Hargrave." The present is a species with which I have very little acquaintance in a wild state, having only occasionally met with a few scattered individuals on the summits of a range of hills in Inverness-shire, in the early part of October ; but it is a well-known and, in some years, a very abundant autumnal visitor to various parts of England, notably to the Humber District in North Lincolnshire, where, as I am informed by Mr. John Cordeaux, it is often met with in flocks of some hundreds.

This species occasionally breeds in the highlands of Scotland, and the nest and eggs have 
been found in Shetland; but the true summer home of the Snow-Bunting is still further to the north, in Iceland, Spitzbergen, Novaja Zemla, and the arctic regions of North America; it also breeds in Norway, Finland, the Faroes, and Northern Siberia. In the few instances in which, as above mentioned, we met with this bird in the highlands of Inverness-shire, we found it exceedingly tame,

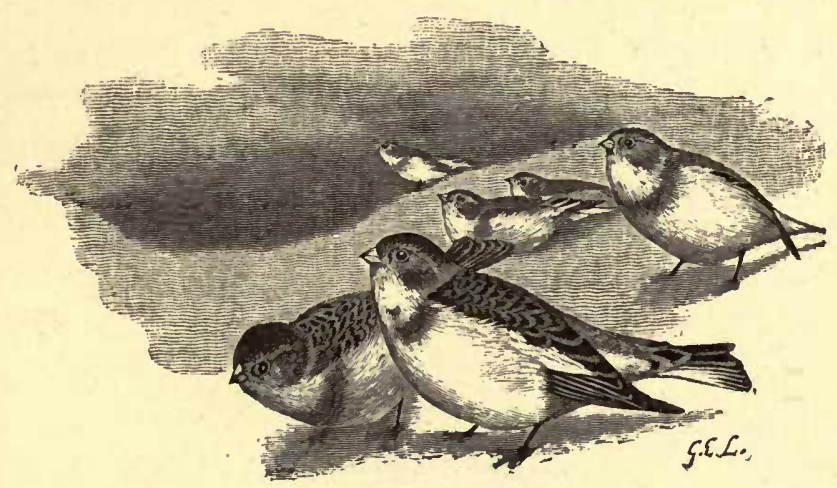

Snow-Buntings.

running about within a few yards of us, and feeding on the seeds of various grasses which grew by the burn-sides: in one instance the bird was so confiding that I nearly caught it with my cap; but this was no doubt caused by the fact that a Merlin was hunting over the moss at the moment when the "Snowflake," as this bird is often called, fluttered up at our feet. The call-note of this species is pleasing and musical, and the male has an agreeable song, which, however, I have only heard from a caged bird. In captivity the Snow-Bunting will eat almost any sort of seed, and generally dies of plethora unless 
strictly dieted. For a description of the nest and eggs of this species, I must refer my readers to Yarrell and other authors; the usual nesting-places appear to be amongst masses of stones or in crevices of rocks, and the bird has been known to breed in captivity in a hole amongst artinicial rock-work.

Since the above article was written, I have received several notices of the occurrence of Snow-Buntings in our county; but the only one that I consider as worthy of special record is that of a flock of about ]00 of these birds near Wadenhoe Reservoir on January 22, 1881: from this flock my friend Mr. 'Thomas Hunt, R.N., shot five, and sent four of them to me in London. These were all in the first year's plumage.

\section{R E E D - B U N T I N G.}

Emberiza schœniclus.

This bird is sparingly distributed along our rivervalley during the summer, and is well known to our country-people as Reed-Sparrow. In the early spring the cock bird may be seen perched on a tall reed or bush near the water, from which position he constantly repeats his short and monotonous song. All the nests which we have met with were situated on the ground, or the crust formed by the roots of the common reed, and were composed of moss and sedge, with a lining of reed-tops, and sometimes a little hair. 'The eggs, generally five or six in number, are pale brown, with blotches and irregular streaks of black or very dark brown. I have found a nest with a full complement of eggs as early as March 23rd; but, 
as a rule, I think the first week of April is about the usual time for these birds to commence sitting. In the autumn the Reed-Bunting, to a certain extent, forsakes its summer haunts, and may be met with in the hedgerows in company with Sparrows and Finches, gleaning from the stubbles, and sometimes frequenting our rick-yards, though a few are still to be found at the reed-beds by the river-side. The principal food of this Bunting consists of various seeds, but, in common with most hard-billed birds, it varies its diet in the summer with grubs and caterpillars. I believe that this species usually rears two, and sometimes three, broods in a season. I have found young birds, only just able to $\mathrm{fly}$, at the end of August. Though, as I have said, this bird is well known in our neighbourhood as Reed-Sparrow, and the Yellow Bunting as Yellow Hammer, the eggs of both species are almost always called "Writing Lark's" by the birds'-nesting boys of the district, and on one occasion of my meeting a lad with a freshly taken nest of eggs of the Reed-Bunting, and asking him to what bird they belonged, he replied, "Why, Writing Lark, to be sure," and on my proceeding to ask for a description of this Writing Lark, the ingenious youth gave me a pretty accurate account of the Kingfisher!

I have found the present species common in most parts of Europe that I have visited. Some confusion has been caused by this bird having been occasionally called Black-headed Bunting, a name belonging more properly to Euspiza melanocephala, a species from South-eastern Europe, which has hitherto only been once recorded as having occurred in England. 


\section{COMMON BUNTING.}

Emberiza miliaria.

Though the above adjective common has been long applied to this bird, it is, in fact, as Yarrell says, by no means the most common of our Buntings, and in our part of Northamptonshire is certainly not a very abundant species. A few pairs breed with us and remain throughout the year, but I do not think that it is sufficiently well known to have obtained a local name, though in many parts of England it is known as Corn-Bunting or Bunting-Lark; the former of which is a most appropriate designation, as the bird is generally to be found about the fences of our arable land, where in the spring-time it may be seen perched on a tall spray, dusting itself on the cartroads, fluttering over the young corn with heavy flight and hanging legs, and continually giving forth its tedious and rasping notes, I can hardly call them song. The nest is usually placed on the ground in some thick tuft of grass, sometimes in the growing corn itself; it is a large loosely built structure of roots and strong bents, with a lining of fine grass and hair. The eggs are generally five or six, of a dirty white, clouded with lilac, streaked and spotted with dark brown, and almost always with irregular lines of the same colour. This Bunting is a very late breeder, and even in Southern Spain, where the species is tediously abundant, I have found fresh eggs as late as the end of May. In winter these Buntings flock with other birds about the stubblefields and rick-yards. 


\section{YELLOW BUNTING oR YELLOW HAMMER.}

Emberiza citrinella.

The Yellow Hammer is very common with us, and though not, I think, now so abundant as it was some thirty years ago, is a well-known and conspicuous bird, especially from its great partiality for the neighbourhood of roads and footpaths. The notes of the male Yellow Hammer, though monotonous, are, in our opinion, more pleasing than those of the ReedBunting, and a great improvement upon the wearying noise made by the species last described. This bird sings in fine weather almost throughout the year, and never more cheerily than on a bright frosty morning in mid-winter. The Yellow Hammer is, I think, the most insectivorous of our three commonest Buntings, but, when suitable insects are not to be found, feeds on various seeds, and flocks with other birds in winter at the corn-ricks. The nest is usually placed upon, or close to, the ground in a rough hedge-bottom or shrub-grown bank, but I have once or twice met with it in a bush at the height of a foot or two from the ground, and Yarrell quotes an instance in which a nest was found at an elevation of seven feet among the branches of a broom-plant. Both nests and eggs are too well known to require any description. The species is pretty common, though very local, in certain parts of the northern provinces of Spain in the summer months, but in Andalucia seems to be a rare winter visitor. 


\section{C I R L - B U N T I N G.}

\section{Emúeriza cirlus.}

This bird, though resident and by no means uncommon in many localities in some of our southern counties, is comparatively rare north of the Thames; and the only occurrence of the species in Northamptonshire, with which I was acquainted at the time of the original publication of this article, happened on June 29, 1866, on the afternoon of which day, as I was watching my Emus and other birds in the courtyard at Lilford, a fine male Cirl-Bunting flew down from a high elm tree, settled on the ground within a few yards of where I stood, and began feeding on the grain which had been scattered for the Emus, and at which several Sparrows and Chaffinches were already busy. I had this bird in full view for some minutes, as he hopped about and regaled himself, till he was attacked by a Sparrow, and flew up to the tree from whence he had come. I listened and watched for him on that and for several succeeding days, but neither heard nor saw him again. Since that time, however, a female of this species was taken by a bird-catcher on 'Tichmarsh, on December 18th, 1884, and brought to Lilford alive, but only survived capture for a few days. Mr. W. Edwards, who has a fair acquaintance with British birds, assured me that he clearly identified a male Cirl-Bunting near Achurch on May 27 and 28, 1889. In England I have met with the Cirl-Bunting pretty frequently in both North and South Devon, in Hampshire, the Isle of Wight, and once in Berkshire. Yarrell states that it is known to have bred in our bordering counties 
of Buckingham and Warwick, and I have little doubt that it also breeds occasionally in the southern division of Northamptonshire, and only requires looking for. It is a very local bird, somewhat resembling the Yellow Hammer in general habits, but seldom affects the open country, in which that bird is so often to be found, seeming to prefer enclosures, and to have a special liking for high elm trees. I have noticed this last particular both in South Devon

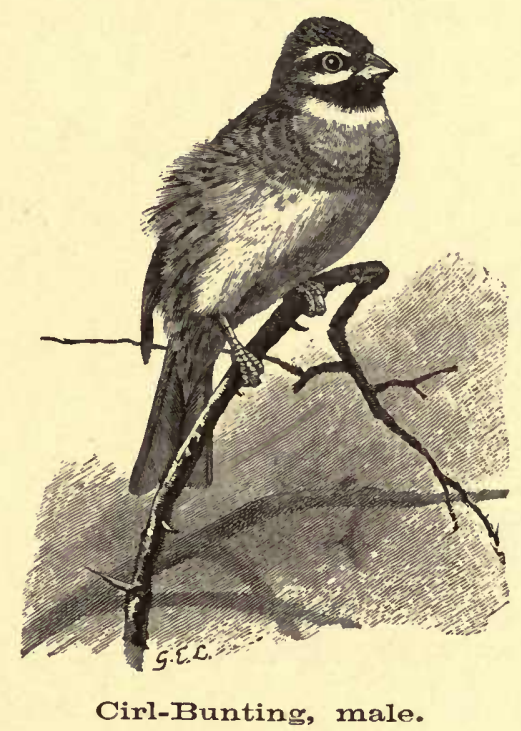

and Hampshire. The song of the male differs slightly from that of the Yellow Hammer, but is rather more sibilant, not so prolonged, and easily distinguished. This bird is much less lively and active than the last-named, and is rather dull and heavy in its movements and habits. The food of this species consists of various seeds and berries, varied during the summer with insects of various 
kinds. Yarrell says that the young are supplied by the parent birds almost solely with grasshoppers, and in Spain, throughout which country this Bunting is exceedingly common, I have seen the old birds taking moths to their nestlings. The few nests I have met with were all placed on steep banks by the side of a road or footway, amongst low bushes and herbage, and were built of moss and grass-stalks, with a lining of cow's hair. The eggs are generally five, white, with a lilac tinge, and thickly spotted and streaked with black or dark brown. I have kept Cirl Buntings in confinement, but they have few attractions as cage-birds, being, in common with other Buntings, dull, silent, and greedy, and without any remarkable beauty of plumage. This species is common in Algeria, where I found it breeding at some four thousand feet above the sea.

\section{C H A F F I N C H.}

Fringilla calebs.

This is decidedly one of the most abundant birds in our neighbourhood, and is too well known to require a detailed notice at my hands. An interesting account of the reasons for bestowing the epithet "calebs" on this species will be found in the 9th part of the 4th edition of Yarrell's 'British Birds' (pp. 70, 71); and in reference to the real or supposed separation of the sexes in winter, I may state that, with us, there appears to me to be a great increase in the numbers of our Chaffinches every year at the beginning of the cold weather, and undoubtedly the females at that season seem to form 
a vast majority, though, as mentioned in the work to which I have just referred, it is possible that some of these supposed females may be young males of the year which have not acquired their full plumage. The Chaffinch is a lively active bird, and his cheery song, though not of high merit, is pleasant and, comparatively speaking, very powerful. The nest is one of the most beautiful works of the kind to be met with in our country, and altogether I think that this species is deservedly a favourite. The Chaffinch is more or less abundant over the whole continent of Europe, and is by no means uncommon as a winter visitor to the neighbourhood of Algiers, where, however, a closely allied and beautiful Chaffinch, Fringilla spodiogenia, takes its place as the resident species.

\section{B R A M B L I N G.}

Fringilla montifringilla.

This bird is a pretty regular winter visitor to our district, generally arriving about the middle of October, sometimes in vast numbers, whilst in some seasons it is comparatively scarce ; it must, however, be a very exceptional year in which more or less of these pretty birds may not be found amongst the old beech trees in front of the house at Lilford in the latter part of October, and, in ordinary instances, throughout November and December. The Brambling with us seems to feed almost exclusively on the fallen beech-mast, as long as there is any to be found, but in snow, or very severe frosts, they betake themselves, with other Finches, to the stackyards; we 
very seldom see them about the open fields. This species is much more shy and wary than the Chaffinch, which in general habits it greatly resembles; the call-note has a certain similarity to the pink pink of the latter bird, but is much sharper and quite unmistakable; the song is a low, somewhat hoarse performance, very truly likened by Yarrell to

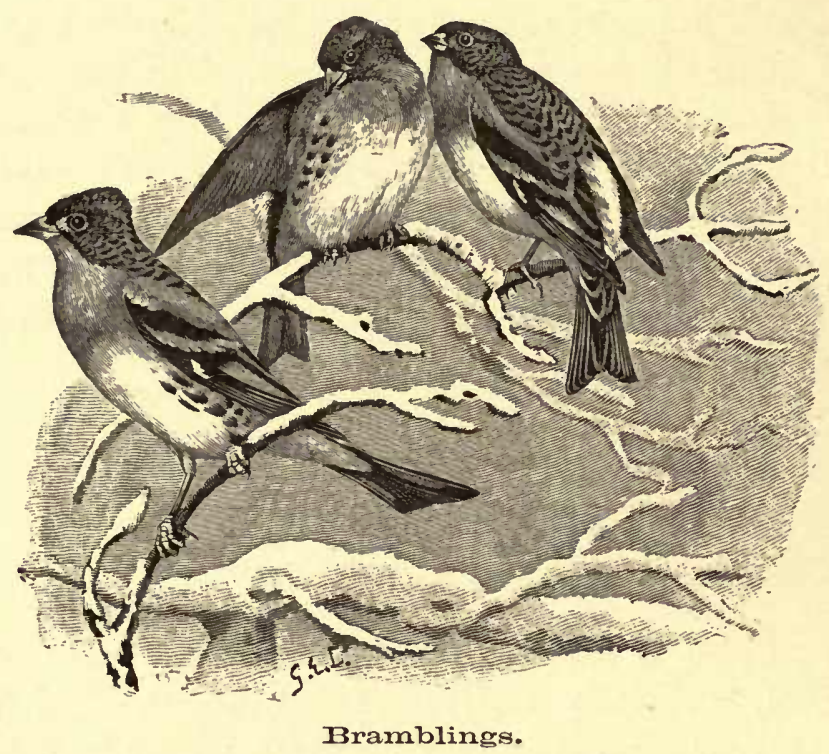

that of the Greenfinch. This species is not known with certainty to have bred in our country in a wild state, though several instances of its having nested and laid eggs in captivity are recorded. The favourite breeding-places of the Brambling appear to be the birch-forests of the mountainous ranges of Norway and Sweden. A nest from the former country in my possession much resembles that of the Chaffinch, but is larger, and lacks the lichens which are generally 
used by that bird, being built externally of green moss, with small strips of birch-bark, and lined with, I believe, human hair, a little wool, and a few feathers, amongst which latter is one from the breast of the Goshawk. The eggs, five in number, are not to be distinguished in colour and markings from those of the Chaffinch, but are rather more pointed at the smaller end than average eggs of that species. The above-mentioned nest was taken from a birch tree at about twelve feet from the ground. The Brambling is a common winter visitor to the south of Europe, and is well known at that season in certain parts of Andalucia. I did not meet with it in Algeria. A female of this species came aboard my yacht in November 1873, in the middle of the Bay of Biscay, about halfway between Ushant and Cape Finisterre. I have kept several of these birds caged; but, beyond their beauty, they have few attractions, and I never succeeded in making them really tame or in any degree familiar.

\section{TREE-S PARROW.}

Passer montanus.

This species is tolerably common, and breeds in many parts of North Northamptonshire. In the winter months the Tree-Sparrow may be found in considerable numbers about our hedgerows and stackyards in company with House-Sparrows and the various species of Finch which resort thither at that season, but in the spring these birds separate from their congeners, and are to be found nesting generally in small colonies of three or four pairs in old hollow 
trees, especially (in our neighbourhood) decayed ash, willows, and walnuts. The nest is generally built in a hole at a considerable height from the ground, and is composed of dry grass with a lining of feathers. The average complement of eggs is about six ; they very much resemble those of the House-Sparrow in colour and markings, though, as a rule, the groundcolour is lighter than in those of that species, and the size considerably smaller. 'The Tree-Sparrow is a lively, active bird, with a good deal of the habits and manners of his more common relation, but without the familiarity and impudence of that bird, in fact we are inclined to consider the present rather a shy species, and although there are certain localities in the vicinity of Lilford in which we can always be pretty certain of finding the bird, the obtaining of specimens when required is by no means equally certain. The ordinary notes of the Tree-Sparrow are sharper and more shrill than those of the HouseSparrow, to which, however, they have a great resemblance, at the pairing-season we have occasionally heard a sort of prolonged chatter from the male bird, which we presume to be the "proper song" mentioned in the fourth edition of Yarrell's 'British Birds'; far be it from us to pronounce it improper, but we question its title to be considered as a song. The chief peculiarity of the Tree-Sparrow is the close resemblance of the sexes, which are indeed hardly to be distinguished in plumage from each other. We have met with this species in various parts of the continent of Europe, but nowhere in great abundance; in England it is certainly more common in the eastern than the western counties, though not rare in certain portions of Lancashire 
and Cheshire. The food of this bird consists of seeds of many kinds, varied in summer by insect diet, as is the case with all the species of this family. In captivity the Tree-Sparrow thrives well upon canary- and millet-seed, and becomes very tame.

\section{H O USE-S PARR OW.}

\section{Passer domesticus.}

This bird is so thoroughly well known by every one in town and country that we feel that any details as to its habits would be quite superfluous. We do not consider that Northamptonshire, or at all events that portion of it with which we are most intimately acquainted, is by any means remarkable for an abundance of Sparrows, though they are quite sufficiently common. I find that the Sparrows which manage to get through the meshes of the wire netting of a portion of the aviaries at Lilford soon become so fat that they are unable to get out again, though this is not the case with Chaffinches, Green Linnets, and various other birds which also intrude there. Though the damage done by these birds to the farmer at certain seasons is very considerable, and I personally owe them a grudge, on account of the quantity of grain and seeds intended for other birds which they devour, I am of opinion that they compensate us to a certain extent for such petty larceny by the amount of destructive caterpillars and grubs which they destroy in the summer. The present species is more or less common in most parts of Europe which we have visited, with the exception of certain parts of Italy and the islands of Sicily, 
Sardinia, and Malta, in which localities its place is occupied by two very closely allied species, the Cisalpine, and so-called Spanish, Sparrows, Passer italice and P. salicicolus. In the neighbourhood of Algiers we met with the three species, but our present bird is there in a small minority, whilst throughout Spain it is the prevalent representative of the Sparrow family in the towns and villages, the Spanish Sparrow being generally found in the less frequented parts of the country, nesting in large colonies in woods and thickets, evincing a remarkable partiality for the neighbourhood of nests of certain birds of prey, e.g. the Common and Black Kites; we have, in fact, often found nests of this last-named Sparrow actually built in the substructure of those of the two species just mentioned, and can only presume that the Sparrows court such vicinity as a protection from the smaller Falconidæ, their deadly enemies. The House-Sparrow, though perhaps the most familiar and impudent of birds, is extremely wide awake and cautious about traps and snares, and, his suspicions of danger once aroused, is very difficult to catch. This of course applies to the old birds only; the young are easily taken during the first summer of their existence, but soon learn to make themselves scarce on the appearance of a gun, and to appreciate the difference between that weapon and a walking-stick. We have met with and heard of many white, cream-coloured, and pied varieties of this species in various parts of our county.

Since writing the above article, I am sorry to say that I have had reason to alter my opinion as to the value of the compensation afforded by this species in the destruction of noxious insects, for its ravages 
in the corn-fields and stackyards, to say nothing of gardens, and have reluctantly come to the conclusion that in our neighbourhood, at least, the Sparrow may fairly be considered as simply detrimental.

\section{H AW F I N C H.}

Coccothraustes vulgaris.

Till the spring of the year 1870 we only knew the Hawfinch in the neighbourhood of Lilford as an occasional and by no means a common winter visitor. On April 4th of the year just named I observed some half a dozen or more of these birds haunting the old thorn-bushes on our lawn; they remained about for some days, but, in spite of minute and protracted search in the most likely localities, we could not discover that they attempted to nest with us, and they had all disappeared before the middle of April. A pair or more, however, undoubtedly did breed not far off, for in July and August I constantly observed some of the species about our kitchen-garden. In the very severe weather of December 1870 and 1871 we were visited by very large flocks of Hawfinches; and since the date last named some of these birds have nested regularly about our pleasuregrounds, and have become only too well known to our gardeners and cottagers from their constant and serious depredations amongst the green peas and other vegetables. Several young Hawfinches taken from the nest have been brought to me during the last few years, and in 1880 a pair were brought to Lilford alive from a nest not far from the house; this nest was built in a young oak tree close to a 
footpath in a large wood, and within ten days after the taking of the young Hawfinches was occupied by a Wood-Pigeon, who added a few twigs to the nest, and thereupon hatched and reared two young. I have been informed of the nesting of Hawfinches at Deene, Weldon, Bulwick, and near Northampton, so that we may now reckon this species as a regular resident in our county. The Hawfinch is a very shy and wary bird, by no means easy to approach, but in captivity becomes very familiar, and though its vocal

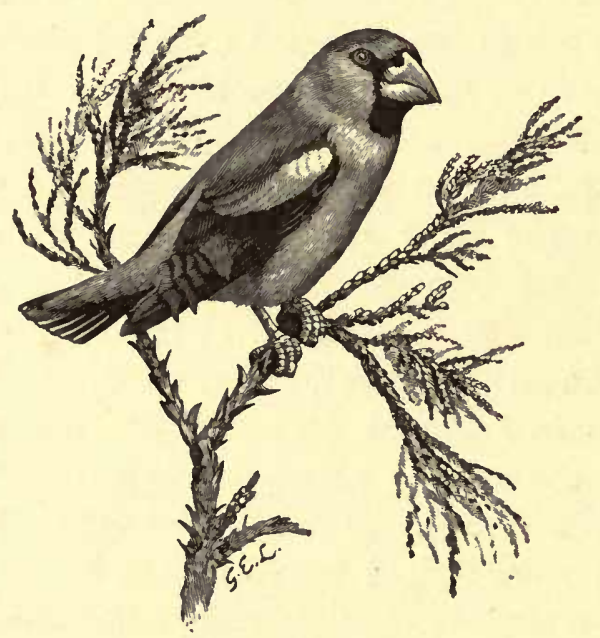

Hawfinch.

capabilities are not remarkable, is amusing from its grotesque manners and attitudes. In the winter months the food of this species consists of beechmast, the seeds of the hornbeam, and the kernels of haws and other berries. I have often noticed that the Hawfinch rejects the flesh or pulp of fruit, and appears to care only for the seed or kernels, for 
obtaining which objects its powerful beak is most admirably adapted. When not engaged in seeking for food these birds generally select the highest branches of some tall tree, whence their peculiar sharp call-note may often be heard, and whence, on the slightest alarm, they dart off with a very swift undulating flight to some other safe look-out station. The nests of this bird which have come under my observation have all been placed at some height, fifteen to thirty feet, from the ground, for the most part in hawthorns or oaks; but evergreens of various kinds and apple-trees are often selected for this purpose. The nest is large and loosely built of pliable twigs and tree-lichens, with a lining of fine roots, hair, and sometimes a little grass. The eggs are of a pale greenish blue, spotted and streaked with dark brown; the usual complement is five, though we have now and then met with six. It appears from Yarrell and other ornithological works that the Hawfinch has been and is extending its breedingrange in this country generally, but that it is most abundant in what are known as the home-counties, Middlesex, Surrey, Kent, Essex, \&c., in most of which it has long been known to nest regularly, whilst in certain parts of England it is still considered a rare bird at all times. Morton makes no mention of the Hawfinch in his Natural History of our county; and it seems improbable that such a peculiar and, to a certain extent, conspicuous bird should have escaped his notice unless very uncommon. In my Harrow school-days we several times met with nests of the Hawfinch in that neighbourhood, and a few of these birds were generally to be found in the gardens and pleasure- 
grounds of Holland House, Kensington, though I do not recollect to have heard of their breeding there. I have never noticed that the Hawfinch associates with other species, and in the gardens around Lausanne, where this bird and the Common Crossbill, Loxia curvirostra, were both exceedingly common in the winter of 1850-51, the two species always kept apart, probably on account of the pugnacious character of the Hawfinch, as the Crossbill is remarkably sociable and apparently fond of the company of other birds. My two caged Hawfinches above mentioned readily devoured meal-worms and house-flies, but I imagine that this is an unnatural and acquired taste. We have met with this species in various parts of Europe; it is locally very abundant in Southern Spain, where it is commonly known as "Cascanueces," $i$. e. Nutsheller. In the neighbourhood of Algiers we found it in small numbers throughout our stay in the country, which extended from the end of October 1877 till May 1978. It is perhaps hardly necessary to mention that this bird is often known in this country as the Grosbeak.

In illustration of the irregular habits of this species I may add that in May 1892 we found seven or eight occupied nests of Hawfinch in yews and hawthorns on the pleasure-grounds at Lilford, and many others were reported in the immediate neighbourhood. On the other hand, no news of a nest of this bird reached me from any part of our surrounding district either in 1893 or 1894. 


\section{GRE EN F I N C H.}

\section{Coccothraustes chloris.}

This is one of our most abundant resident species, and too well known to require much detail at my hands. It is not a bird of any particular merit, except as a destroyer of caterpillars, and it therefore is worthy of protection in spite of the accusations brought against it by many gardeners, with a certain amount of reason, of destroying the buds of various fruits, and a particular fancy, to which we can testify, for young lettuces and other plants of that order. The Greenfinch seems to especially affect evergreen shrubs, both as nesting- and winter roosting-resorts, and in our youthful nocturnal bird-catching excursions was the species which suffered most frequently amongst the laurels, box, laurustinus, \&c. of the Northamptonshire gardens and shrubberies. This species appears to pair early. We have often found nests containing eggs in the first week in April, and three, if not four, broods are often reared. The male bird has a habit of floating in the air, singing his best during the pairing-season, but his best is, to our ears, a poor performance, and his ordinary ditty tedious and monotonous to a degree. I think that five is about the average complement of eggs, but have several times met with six. In the winter months the Greenfinch resorts to the hedges and stubbles in company with other allied species, and may often be found about the stackyards, but generally returns to the favourite evergreens at nightfall. This bird is common in most parts of Southern Europe and in Algeria, in which last 
190 THE BIRDS OF NORTHAMPTONSHIRE

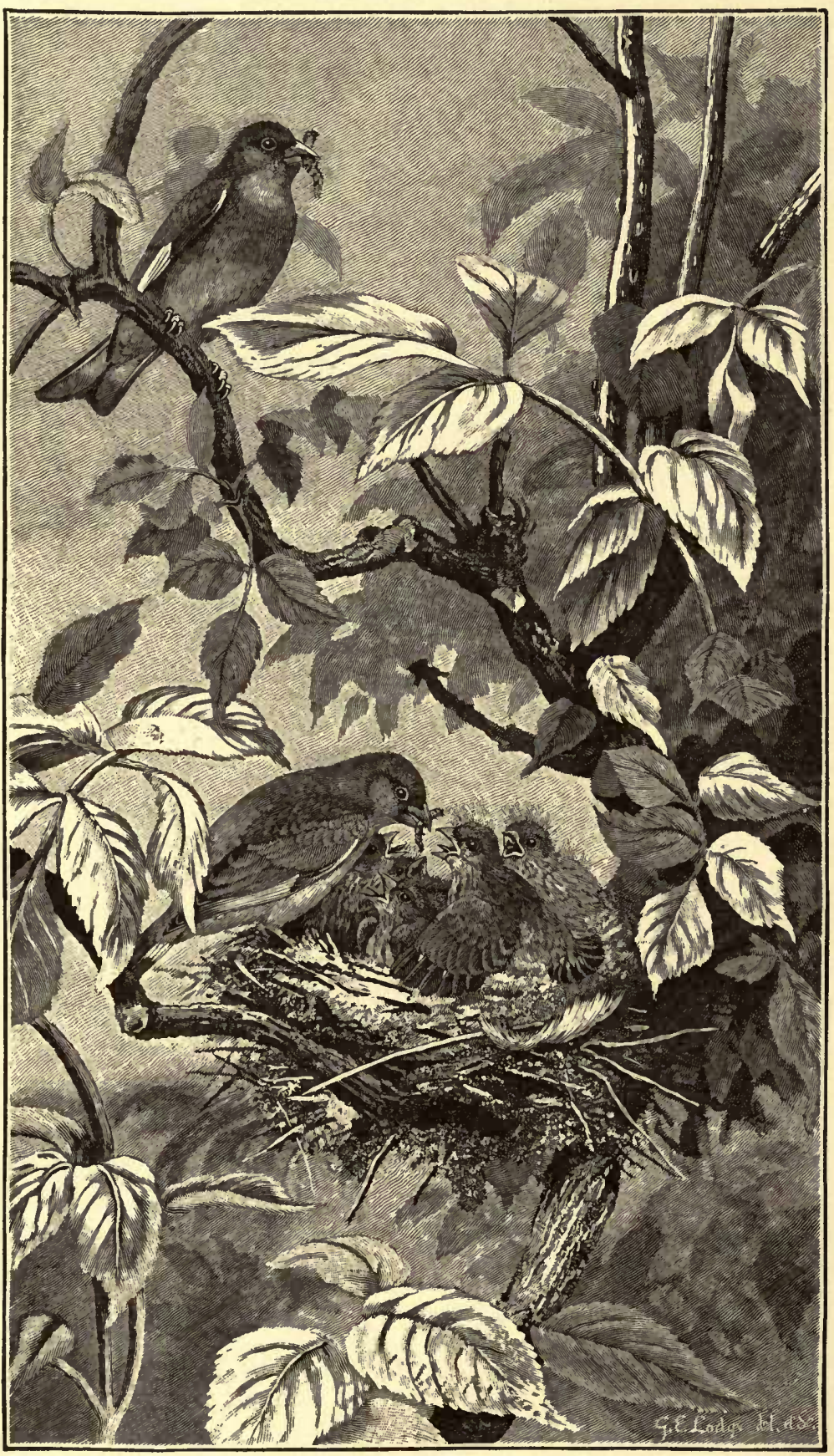

Greenfinches, with nest and young. 
country a very brilliantly coloured race or variety, which has been raised to the rank of a distinct species by some ornithologists under the name of Fringilla aurantiiventris, is equally abundant. This bird presents no difference in notes, habits, or structure from the ordinary European type, and is only distinguishable by the vivid intensity of its plumage.

\section{GO L D F I N C H.}

Carduelis elegans.

This beautiful little bird, though said to be less common with us than it was before the practice of careful field-weeding became general, is, I am glad to say, still well known, and by no means rare in most parts of our county as a resident species, whose numbers are increased in most winters by flocks of strangers,-I mean birds not bred in our district. The Goldfinch is so justly a favourite, from its cheerful song and beauty, that it is perhaps the bird which suffers more than any other from the cunning of the bird-catcher, and we have of late years been grieved to find several of these artists plying their trade with limed twigs and call-birds about our highroads and lanes, but it is in the neighbourhood of our large towns and on our southern coasts that the principal havoc has been wrought amongst these delightful little birds. In the fourth edition of Yarrell's 'British Birds,' vol. ii. p. 118, will be found a quotation from the 'Zoologist,' in which the writer estimates "the average annual captures of this species near Worthing at about 1154 dozens, nearly all being cock birds." 
This statement was published in 1860. The editor of the edition of Yarrell's 'British Birds' goes on, loc. suprà cit., to quote Mr. Swaysland, a well-known bird-preserver at Brighton, who, in his evidence before the Select Committee on Wild Birds Protection, printed July 23,1873 , states that formerly a boy could catch forty dozens of Goldfinches in a

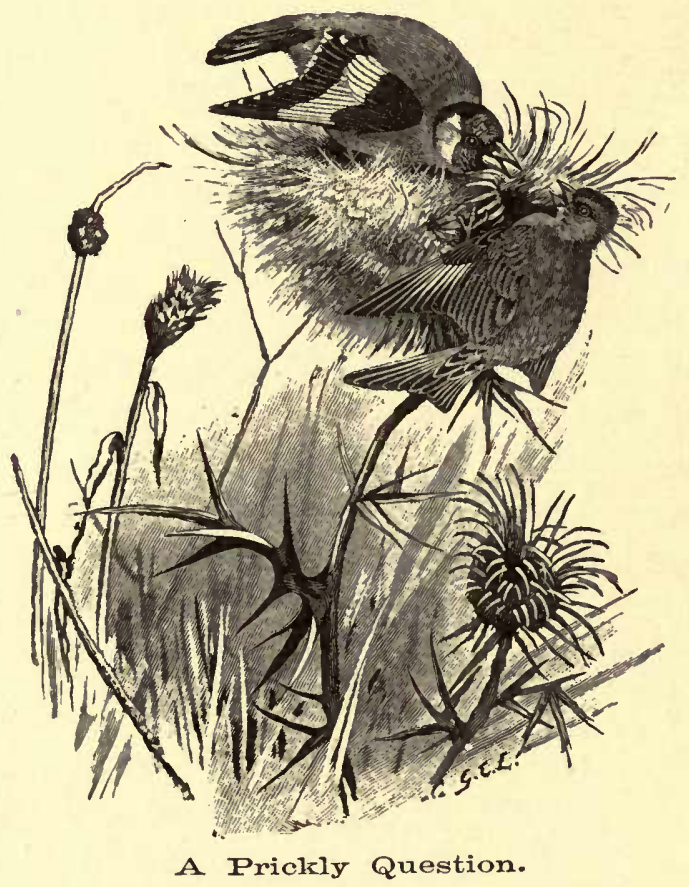

morning within ten miles of Brighton, whereas they are now comparatively scarce, and not a hundred may be seen even at the most favourable time of year. In April our flocks of Goldfinches break up, and leaving their favourite autumn and winter resorts in the rough pastures and the roadside fences, distribute themselves in pairs about our shrubberies 
and gardens. We have usually at least two nests in the flower-garden at Lilford quite close to the house, besides several more at a short distance. The exquisitely neat little nest is by no means always easy to discover, being often placed at the end of a leafy bough of oak, horse-chestnut, plane, or other large-leaved tree, not unfrequently amongst the topmost twigs of a fruit-tree, and now and then near the top of a tapering cypress or Irish yew. The eggs are generally five, and are probably too well known to my readers to require description. The partiality of the Goldfinch for the seeds of the thistle and other of our common weeds is well known; and a prettier sight to the eye of a lover of birds than a flock of these little living gems busily engaged in examining a tall patch of flowering thistles is hardly to be met with in this country. In captivity the Goldfinch will readily mate with the Canary, Greenfinch, Common Linnet, and other species, and is remarkable for its docility in learning various tricks; but, as the editor of the fourth edition of Yarrell's 'British Birds' most truly remarks, all this is "violating the laws of nature," and, in our opinion, very much to be deprecated. The Goldfinch is found in all parts of Europe which we have visited, from Corunna to Cyprus, and is very abundant in Algeria.

\section{S I S K I N.}

Carduelis spinus.

Although this bird cannot be called abundant in our neighbourhood, I have never failed to meet with it in small flocks whenever I have been at Lilford in the months of January and February. A few appear 
on the banks of the river during severe weather in January, and generally remain with us for several weeks, some occasionally prolonging their stay till April; but, as a rule, we seldom see them later than the beginning of March. Whilst with us, the favourite haunts of the Siskin are the groups of alders near the river, the small flocks, in which the females always greatly outnumber the males, keep together, constantly uttering a musical call-note, and cluster in all sorts of positions upon the sprays which hang over the water. 'The Siskin is one of the most naturally tame and familiar birds with which I am acquainted, and becomes immediately reconciled to a cage. I well remember an instance in which a male bird of this species, which had not been caught more than a few days, escaped from his cage, but returned to it in the course of an hour or two, and this without the attraction of a companion in captivity, and in spite of an abundance of favourite food in the shrubbery into which he had made his way. The Siskin breeds in considerable numbers in the Highlands and occasionally in other parts of Scotland, and many instances of its doing so in England are on record; it will nest freely, in favourable circumstances, even in confinement. From its extreme tameness, pleasant notes, and beauty it is a most attractive cage-bird, and thrives well in confinement. As we never have had the good fortune to meet with a nest of this species, we must refer our readers to Yarrell's 'British Birds' for a full account of its breeding-habits, eggs, \&c., and will only here add that it is known as a winter visitor to most parts of central and southern Europe, in which it occasionally and irregularly remains to nest. The Siskin is also 


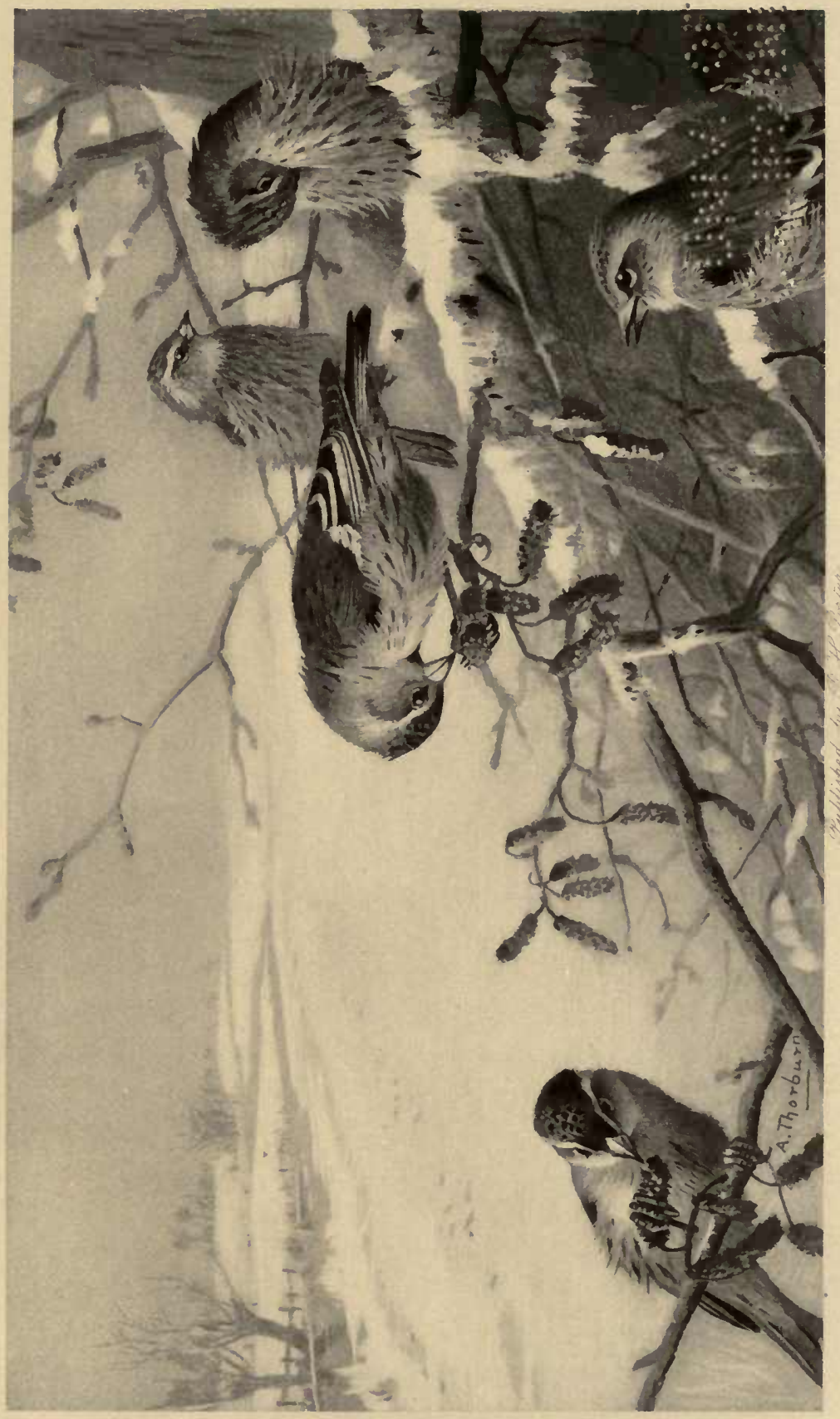




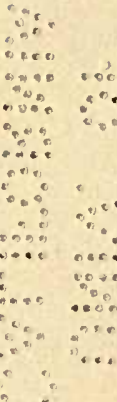


recorded to appear in Algeria and Morocco, but we did not meet with it during our seven months' stay in the former of those countries.

\section{MEALY REDPOLL.}

\section{Linota canescens.}

'The earliest record of the occurrence of this bird in our county with which I am acquainted is to be found in the fourth edition of Yarrell's 'British Birds,' vol. ii. p. 136, where mention is made of "one shot at Oundle by the late Mr. Pelerin sufficiently advanced in its plumage to have acquired a considerable portion of red colour on the breast." The only other instances of capture that I know of in Northamptonshire are those of a female taken near Lilford by a bird-catcher on October 21, 1885, and two others taken by a member of the same craft near Roade in December 1893, and most obligingly sent to me by Mr. W. 'Tomalin of Northampton. 'This is a species with which we have no personal acquaintance, except as a cage-bird. Its habits appear to resemble very closely those of the Lesser or Common Redpoll, and it seems that a considerable amount of confusion has arisen amongst ornithological writers in the discrimination of the two species. The present is a truly northern species, which occurs irregularly and in varying numbers, chiefly in our north-eastern and eastern counties, during the winter months. I can meet with no authentic record of its having been known to breed in our country. 


\section{LESSER REDPOLL.}

\section{Linota rufescens.}

So far as my own observation goes, this little Finch is not very abundant at any time of year in our immediate neighbourhood, and with one exception I have only met with it therein during the winter months. The exception occurred in September 1880, when, whilst shooting near Tichmarsh, we fell in with about a dozen of this species haunting some willows along a brook-side, with every appearance of belonging to and having established themselves in the locality. Mr. A. G. Elliot, of Stamford, informs me that the Redpoll breeds not uncommonly in the vicinity of that town, and it is by no means improbable that it may now do so with us, but, as I have before stated, I am hardly ever at home in the nesting-season, and it would be a difficult and thankless task to teach our bird-nesting youths to discriminate between this and other allied species. About Lilford these birds appear occasionally in flocks of from twenty to fifty or sixty, almost always in very severe weather, and then haunt the alders by the river-side, their habits and manner of feeding at that season much resembling those of the Siskin as above described. They are exceedingly tame, and may be very closely watched as they cluster like bees on some hanging sprays, searching for buds, and keeping up an incessant twittering music, pleasant enough, but not by any means so melodious as that of the Siskin. It appears that the Lesser Redpoll breeds in many parts of England, occasionally in great abundance, but is more abundant at the nesting-period in the northern and 
eastern counties than in the south. As I have never myself met with a nest containing eggs which I could positively identify as belonging to this species, I must refer my readers to the very full and interesting details given in the fourth edition of Yarrell's 'British Birds.' 'This bird is such a common and deservedly favourite cage-bird that any description of its song and habits in captivity appears to me unnecessary.

Since writing the above I have been obligingly informed by Mr. W. L. Chapman, of Northampton, that he has twice met with nests of the present species in this county. In a letter dated January 29, 1881, he states that "the first instance was about twenty years ago, in a gooseberry-bush near the General Asylum, Northampton. The other was in a hedge that surrounds Brampton Bushes, about three miles from Northampton. There were five eggs in this nest, as high in the hedge as a man could reach. When the hen was put off she flew round calling, and was soon joined by the cock bird; they continued flying round together till she went on to the nest."

\section{L I N N ET.}

\section{Linota cunnabina.}

This bird, which is known as Brown, Grey, and Red Linnet, though well known and common in our district, is by no means one of our most abundant representatives of its family, being a species which particularly affects open commons and furze brakes, in which sort of localities our part of the county is somewhat deficient; wherever furze is found, how. ever, there we may be pretty certain to find the Linnet in the spring, and there is the spot in which 
the nest is generally to be found. In the winter months these birds resort to our stubbles and may be seen flitting in small flocks in search of seeds from place to place, seldom, so far as my own observation goes, joining company with other birds, and, curiously enough, almost always roosting on the ground. The song of the Linnet at its best is exceedingly sweet and pleasant, but varies greatly in individual birds, as does the summer dress of the males, some of which assume a brilliant rosy red upon the head and breast, whilst in others the new colour is a dull red-brown; and in a footnote in the fourth edition of Yarrell's 'British Birds' will be found mention of a variety in which the breast is of a fine lemon-yellow colour. The most brilliantly coloured Linnets with which I have met were in the north of Spain in the early summers of 1867 and 1876, and we also procured a very brightly coloured male in the little-known island of Scarpanto in 1875. This species is abundant in all parts of Europe with which I am acquainted, as also in Algeria and Tunis. In captivity the Linnet thrives and sings admirably. I was acquainted with one of these birds which had been caged for nearly nine years, and appeared to be in good health, and many cases of a much longer imprisonment, with apparently perfect health and vigour, are on record.

\section{TWITE.}

\section{Linota montium.}

So far as our own experience goes, this bird is an irregular and uncommon visitor to Northamptonshire, only making its appearance with us in very severe weather; but Mr. W. L. Chapman, whom I have 
previously quoted concerning the Lesser Redpoll, informs me that many Twites visited the neighbourhood of Northampton during the early winter of 1880 , and I gather from his letters that he does not consider it as an uncommon autumnal visitor in that part of the county. In general habits this bird much resembles the Common Linnet, but its distribution during the breeding-season in our Islands is much more local, as it especially affects open moorlands, and often nests on the ground in these localities, and, as a rule, only appears in the wooded and cultivated lowlands as an autumnal bird of passage. Our own acquaintance with the Twite, or, as it is often called, the Mountain Linnet, is chiefly confined to having often met with it on the moors of Scotland, Yorkshire, and Cheshire, when Grouse-shooting, in the months of August and September. At that season it is generally to be met with in small family-parties of six or eight, flitting about grassy spots amongst the heather, and feeding on various small seeds. It may be distinguished, even at some distance, from the Common Linnet on the wing by its lighter make, darker colour, and sharp call-note. In captivity this species becomes very tame, but has not much to recommend it, as the song though sweet is short, broken, and of little power. We have never personally found the nest of the Twite, which is said to be built of fibrous roots, or twigs, grass, moss, and wool, and usually lined with feathers, hair, or fur; the eggs are generally five, and very closely resemble those of the Common Linnet. 


\section{B ULLFINCH.}

\section{I'yrrhula vulgaris.}

This well-known and handsome species is very common in our neighbourhood, and though never, to my knowledge, met with in numbers sufficient to justify the name of a flock, may certainly be considered one of the most typical birds in our district. In the autumn and winter months, the old rough fences so common in this county supply the Bullfinch with an abundance of its favourite food, in the shape of hips, haws, and many other berries; and on such fences it may be found, and closely observed in small parties of seven or eight, which follow the line of hedge, busily feeding, and calling to one another with a low single note. At the approach of spring these birds come into our kitchen-gardens and orchards and commit great ravages on the early buds of the gooseberry and other fruits. It appears to be somewhat doubtful whether the Bullfinch in any way makes amends for the mischief thus committed, by the destruction of any injurious insect. This is a point which I would strongly recommend to the consideration and investigation of such of my readers as may have the opportunity, for the Bullfinch is a very favourite bird of mine, and a great ornament to our gardens and shrubberies. The nest and eggs of this species are so peculiar and well-known that I think it superfluous to describe them here; a very favourite site for the nest, in this neighbourhood, is a thick young yew-tree or a dense box-bush, but it may be met with in almost any quiet place with thick covert. The hen bird sits very close, and may often be taken on the nest. The natural song of the Bullfinch is 


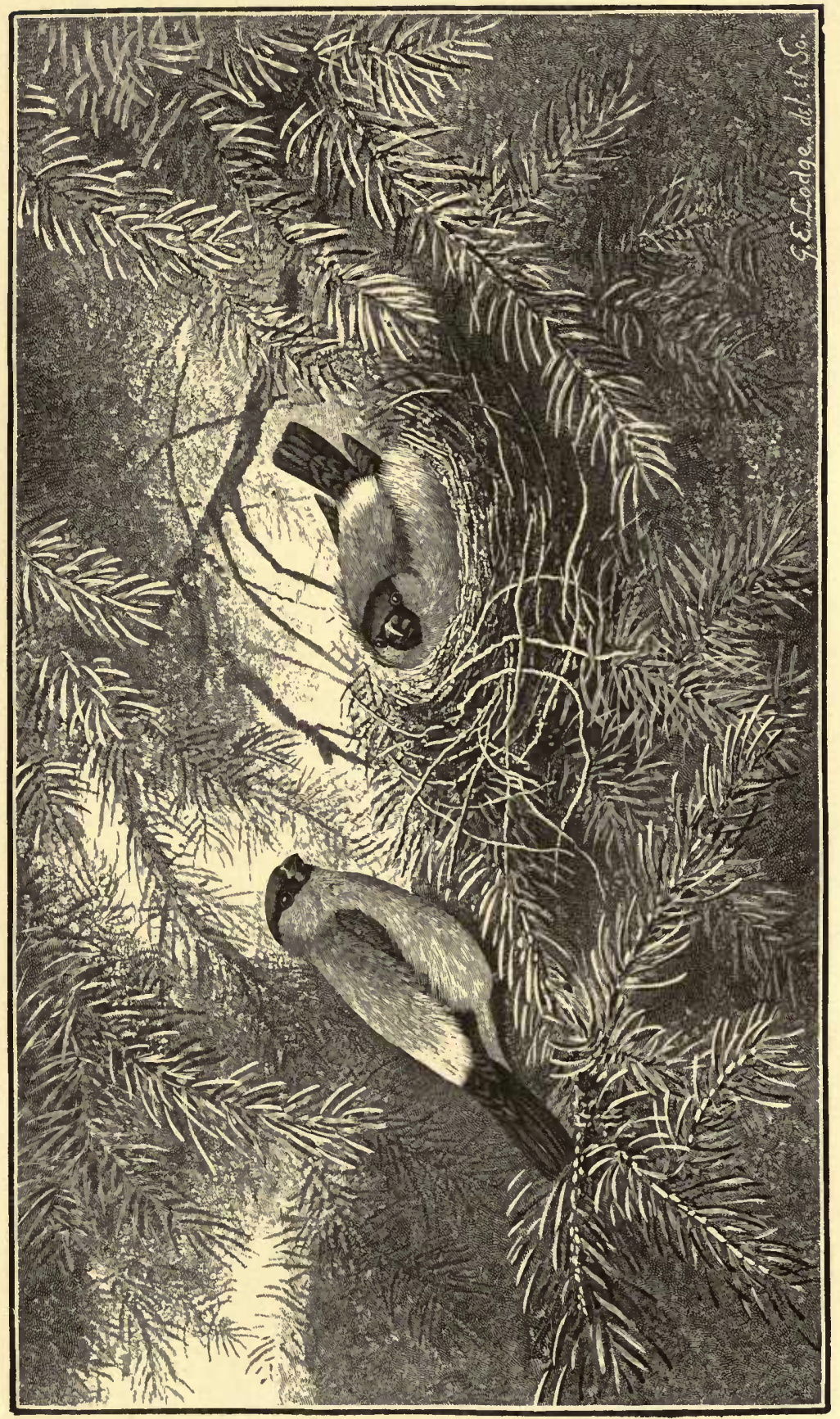

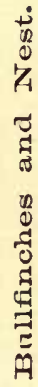


not a brilliant, but, to my taste, a very pleasing performance, and infinitely preferable to the "piping" of tunes artificially taught. This species is, from its extreme docility and beauty, a very favourite cagebird in this country and on the continent, and with proper care will live and thrive for many years in confinement, and has often been known to breed in that state. My friend Mr. Holden Hambrough, of Pipewell Hall, Kettering, has kindly supplied me with particulars concerning a pair of Bullfinches, which, being allowed their liberty in Mrs. Hambrough's sitting-room, for two successive seasons nested and reared their brood in the skull of a deer which hangs over a door. There is a prevalent story in our neighbourhood that if a brood of young Bullfinches is taken and placed out of doors in a cage the parent birds will poisou all but one of their progeny, but, in common with a good many other bird-stories, this very much "requires confirmation." Several instances of melanism in this species have come to my knowledge in Northamptonshire and elsewhere; it is, I believe, supposed that an exclusive course of hempseed as food will produce this effect. The Bullfinch is found in most parts of Central Europe, Northern Italy, and France. In Spain I have only met with it sparingly in the province of Santander, whilst it appears that in Northern and probably Eastern Europe its place is occupied by an almost precisely similar but larger form or species, viz. Pyrrhula major. Of this latter bird I have kept several in confinement, and can perceive no difference in note or habits from those of our common Bullfinch; but I am informed that they will not learn to pipe.

Whilst revising this article for the press, I received, 
as a gift from Mr. G. Bazeley, of Northampton, a jetblack Bullfinch alive, with the information that it was caught when very young at Old Duston, in August 1894. I have seen many dark-coloured Bullfinches, but this bird is of a pure black, throughout.

\section{CROS S B I L L.}

Loxia curvirostra.

Our old Northamptonshire naturalist Morton, at p. 427 of his book previously cited, writes as follows:"'The Shell-A pple or Crossbill, Loxia Gesneri. 'This bird has been shot at Fawsley, and is the only one of the kind I have met with here." I have not myself met with this bird in our county, but have several notes of its occurrence therein from various sources. 'The Rev. M. Berkeley, in a letter dated February 28, 1876, states that "the Crossbill was not uncommon at Milton"; and I was informed by Lady Mary Thompson that several were shot there in the early part of the winter of 1822-23. Mr. A. G. Elliot informs me that several have been killed near Stamford at various times. Mr. J. Hensman mentions a specimen shot at Irchester, November 1866, now in the Northampton Museum ; and Mr. W. L. Chapman, writing in January 1881, tells me that a great number of Crossbills were about Harlestone Firs some years ago. A fine specimen was shot in the Rectory garden at Tichmarsh on August 15, 1888, and is now stuffed and in my collection. 'This bird is in the red phase of plumage, and the Rev. F. M. Stopford, who shot it, informs me that it had a companion, so far as he could see, exactly similar to it. In July 1892, the 
Rev. E. Sylvester, Rector of Deene, told Lady Lilford, for my benefit, that two pairs of Crossbills had nested and reared broods in some fir-trees in his garden at that place during the previous spring. As I felt some doubt as to correct identification in this case, I wrote to my informant, and received a reply which convinced me that the story was perfectly true. This species is an irregular visitor to most parts of Great Britain. It is recorded by Professor Newton, in the fourth edition of Yarrell's 'British Birds,' as having beeu known to nest in seventeen English counties; but in most parts of the country it is regarded as a winter migrant, though to this there are many exceptions, e.g. one to our knowledge in which large numbers of Crossbills appeared in the month of June in the neighbourhood of Holsworthy in North Devon. This species is essentially a denizen of the fir-woods, the seeds of the various conifers forming its principal and favourite food. The Crossbill breeds frequently and regularly in many parts of Scotland, and, according to various observers, usually commences its nesting-operations early in March, for the most part selecting the horizontal bough of a fir; but on this subject we can only speak on the authority of others, and therefore abstain from any details except to mention that a nest taken in Scotland, and sent to me with four eggs some years ago, is built of twigs of Scotch fir and lined with coarse grass and a very little wool. The Crossbill is more or less common in suitable localities in all parts of Europe. We have met with it in great abundance in the Canton de Vaud, Switzerland, from November till April, but could not succeed in finding a nest. In Spain we met with it in the month of June in the 
pine-forests of the Guadarrama mountains, near San Ildefonso, and have heard of its occurrence in many parts of that country. We have generally found the Crossbill very tame and easy of approach, and a flock of these birds busily employed in feeding on the seeds of a snow-laden fir-tree is a beautiful and most interesting sight. Their actions in quest of food very much resemble those of the smaller Parrots as they cling to and clamber about the large cones,

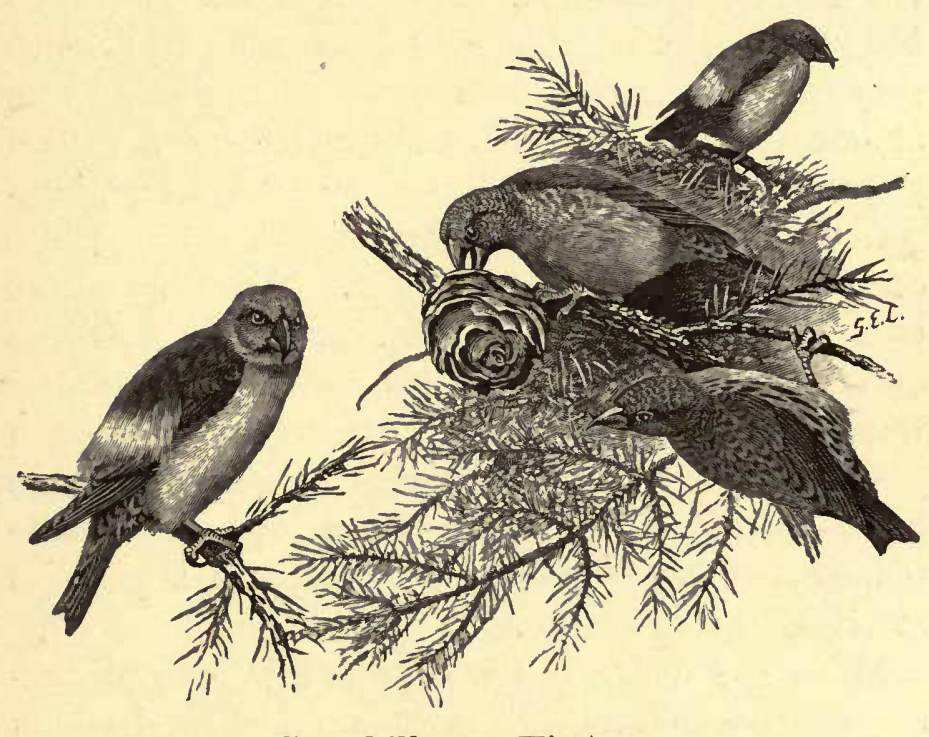

Crossbills on Fir-tree.

from which they extract the seeds with wonderful rapidity. In confinement we have found this species, though it soon becomes perfectly tame, invariably very restless, and constantly climbing over all parts of its cage as if seeking to escape. As above mentioned, fir-seeds are the natural and favourite food; but these birds will readily feed on hemp-seed and almost any of our common berries. At pp. 190, 191 
of the fourth edition of Yarrell's 'British Birds' will be found some quaint quotations from two authors concerning the visitation of Crossbills to this country in the years 1251 and 1593 , and the damage done by them in the apple-orchards by boring into the fruit to extract the pips. In connection with this we may state that although we have found our tame birds of this species very fond of the pips of apples, we never could induce them to extract the said pips from the fruit for themselves. The plumage of the Crossbill varies, according to age and sex, from a yellowish grey with brown stripes in the nestling birds to an almost uniform dull red in adult males, and a general yellowish green in the females; the long wingfeathers and tails are always brown, though the shades of this colour vary considerably. We have found that in captivity the red birds invariably lose that colour at the moult, assuming a plumage of what, for want of a better expression, we may term a brownish green, and never regaining their brighter dress. The ordinary call of this species is a loud single note frequently repeated, but both sexes have a pleasant murmuring sort of song.

Since the above article appeared in our 'Northamptonshire Natural History Journal,' I received, on October 23rd, 1894, a stuffed specimen of Crossbill in green plumage, from Mr. G. Bazeley, of Northampton, who subsequently informed me that it was one of several sent to him for preservation killed at Harleston Firs, out of a flock of about 100 that had been haunting that locality for some weeks. One of this flock in brilliant red plumage was knocked down by a gamekeeper's son with a piece of stick thrown at it. 


\section{STARLING.}

\section{Sturnus vulgaris.}

As may well be supposed in a district so eminently suited to its habits, this well-known bird is exceedingly abundant with us, and we presume that there is hardly a Northamptonshire man, woman, or child who is not more or less acquainted with the "Starnel," as it is commonly called by our country people. We do not therefore propose to enter into any lengthy details as to its habits, which have been fully and frequently described by far abler pens than ours, but perhaps a few observations from our experience in our own neighbourhood may possess some interest for Northamptonshire readers, for whom these notes are specially designed. Some fifty years ago several small spinnies of blackthorn, with a few fir-trees in each, were planted in a large pasture-field adjoining the park at Lilford, and two of these plantations, when the blackthorns had attained a height of some eight or ten feet, were selected as winter roosting-places by myriads of Starlings, which deserted for that purpose several older plantations in the neighbourhood. The numbers of these birds crowding into these small coverts at dusk from the end of September till March were astonishing, and seemed to increase annually for some eight or ten years, when the flocks suddenly abandoned these haunts, and since that time, though a few Starlings still come in to roost, and although the species is certainly as abundant with us as ever, I do not think that $I$ am wrong in stating that the evening flights at the spots above mentioned may now be reckoned by tens instead of by thousands as formerly. 
This habit of suddenly forsaking a favourite roostinghaunt has often been noticed, but, as far as I know, never satisfactorily accounted for. We look upon the Starling as one of the most useful to man of our British birds; the manner in which these birds will clear a turnip-field attacked by " $\mathrm{fly}$ " of this pest has several times come under our especial notice, and is truly marvellous, and although accusations against the Starling of depredations amongst various fruits are not wanting, I never heard any gardener in our neighbourhood speak of it as an enemy. Insects of all kinds form its principal diet, and small parties of Starlings may frequently be seen in calm hot weather hawking slowly high in air in a fashion that has put us somewhat in mind of the habits of a very different species-the Bee-eater, Merops apiaster, as observed in Spain and other parts of Southern Europe. As soon as the young are strong on the wing these birds collect in small flocks, and are often closely waited upon of an August evening by the Hobby, Falco subbuteo, although I do not believe that this little falcon would "bind to," or be able to hold a well-fledged Starling. The great majority of our home-bred Starlings leave us early in autumn, but their places are soon occupied by strangers, who remain or pass on according to the weather. 'This species, as might be expected from the nature of its food, is one of the first to suffer from a sudden severe frost, and we have often picked up Starlings dead or dying about our spring-heads after a few days of such weather. The Starling, besides an infinite variety of natural notes, possesses the power of close imitation of those of many other birds. One which haunted the roof of the house at Lilford deceived me 
many times with an exact imitation of the cry of the Kestrel, and others at various times with that of the chatter of the Fieldfare, the whistle of the Golden Plover, and the cry of the Alpine Chough, Pyrrhocorax alpinus, which they had no doubt acquired from birds of that species in my aviary. White, or partially white, varieties of this bird are by no means very uncommon. A pure white one frequented the park at Lilford for many months; I would not allow him to be pursued or molested, but he, or another precisely similar to him, was eventually shot at Barnwell Castle and sent to me by the slayer with a modest request for $10 s$. The many attractive qualities of this species as a cage-bird are well known, but there is no need for any lover of birds residing in the country to imprison a Starling, as the bird is so common and so familiar that its habits, in a state of freedom, may be closely studied in almost all parts of England. In most parts of Southern Europe the Starling is a winter visitor, and in Andalucia certain reed-fens are hired expressly on account of these birds, which are shot as they come in to roost, pickled, and sent to all parts of the country. To our taste they are extremely nasty as food. There is a theory that pulling their heads off immediately after killing them deprives them of their natural bitter flavour, but we cannot say that we have found them otherwise than repulsive on the table in any circumstances. Several instances have come to our knowledge in Northamptonshire of pairs of Starlings taking possession of holes in trees prepared as nesting-places by the Green Woodpecker. It would be natural to suppose that if the matter came to a contest the latter birds would prove the victors, but we are 
disposed to think that the real reason of the almost invariable victory of the Starling in such cases is that alluded to at p. 232 of the fourth edition of Yarrell's 'British Birds,' viz. the intruders carrying in their nesting materials. In many parts of Southern Europe the place of the Starling as a resident species is occupied by a very closely allied species, the so. called Sardinian Starling, Sturnus unicolor, whose habits are almost identical with those of our common bird.

\section{ROSE-COLOURED PASTOR.}

\section{Pastor roseus.}

The only occurrence of this species within our limits that has come to my knowledge was recorded in the 'Field' of October 6th, 1888, by Colonel E. R. Cottingham, R.A., who shot it in his garden at Weedon on the 10th of September in that year, sent it to me at my request for identification, and subsequently was kind enough to make me a present of it. It is, I think, an adult male, but it had been "set up" (by some very indifferent artist) before I received it. This beautiful bird is a rare and accidental visitor to our country, and its visits are generally put in at a season when its favourite fruits, cherries or mulberries, are at their best. In general habits this species closely resembles the Starling, and its principal diet consists of insects. Vast flocks follow the armies of locusts in Western Asia, India, and South-eastern Europe, and occasionally remain to breed in colonies in localities where they were previously only known as scarce and irregular migrants. They generally nest in the crannies of 
rocks, earth-cliffs, or old buildings, not infrequently in hollow trees; the eggs are pure white. The Rose-coloured Pastor thrives well in captivity, but the constant chatter of even a single bird is almost overpowering in a room.

\section{RA VEN. \\ Corvus corax.}

Although this species was formerly common and well known in our county, we fear that in now treating of it as a Northamptonshire bird we must confine ourselves almost exclusively to the use of the past tense, as the well authenticated notices of its occurrence of late years within our borders which have come to our knowledge are very few and far between. Sir Charles Isham, in a letter dated Lamport Hall, August 28, 1880, writes as follows:"A pair of Ravens were about here this spring, but I did not see them; my keeper did frequently, also another person who knew them well; he thought that they intended to build in an oak tree in a meadow near the brook. I told this to my old groom who had been here all his life, and died above eighty years old a few months since; he told me that he took the last nest in the parish in that very tree more than sixty years ago; he also took one in Scotland Wrood near here when a boy." Mr. A. G. Elliot, of Stamford, informs me that a Raven killed by John Barwell in Haringworth Wood, May 1865, "had a deal of rufous-brown on the upper wing-coverts." Another bird of the same species was seen at the same time but not killed. Mr. J. 
Hensman has informed me that a Raven in the Northampton Museum was shot near Wellingborough in 1868. Mr. G. M. Edmonds, writing in March 1876 , says of this species :- "Single bird twice only seen flying over the Herne (near Perry Mill, below Oundle) in thirty-six years." Our personal knowledge of the Raven as a wild bird in the neighbourhood of Lilford is confined to the fact that at least forty years ago a pair of this species nested in a high elm tree close to the village of Wigsthorpe, and that certainly none have done so since that period. I have many notices of the former abundance of this bird in various parts of Northamptonshire, but, as in the case of our Kites and Buzzards, the Raven has disappeared before the advance of civilization and the increase of the preservation of game, and is now to be met with as a resident only in the wilder parts of our Islands.

We have had many opportunities of closely observing the habits of this eminently sagacious bird in various parts of the world, and, in spite of his tendencies to murder, assault, and robbery, we must confess to a great liking for him. 'The Raven is in this country a very early breeder, generally selecting a secure ledge in a cliff, more rarely a tall tree, and returning to the same locality for nesting year after year. 'The young birds often leave the nest during the first fortnight of March, sometimes before that date. We have more than once heard of a full complement of eggs early in February, and, on the other hand, found unfledged young in more than one Raven's nest as late as the middle of May. The old birds are always wary, one always keeping a close look-out whilst the other is on the nest, and immediately uttering a warning note on the approach 
of danger. We have heard of Ravens vigorously attacking persons attempting to harm their nests, but have never witnessed anything of the sort, our experience being to the effect that, during the siege, the parent birds usually soar high in air over the nest, uttering, besides their usual croak of alarm or anger, a curious sound, like the noise made by drawing a tightly fitting cork from a bottle, occasionally turning complete somersaults in the air, and making ferocious stoops in the direction of the invader, but always keeping well out of gunshot-range. For some time after the young Ravens leave the nest they roam in company with their parents, but soon separate and start off singly or in couples on marauding expeditions on their own account. We often noticed in the highlands of Scotland that the Ravens appeared in force as soon as we began to kill the deer at the beginning of August, and although in some years none of these birds had nested or been observed before the time just mentioned in the particular locality of which we are treating, thenceforward a day rarely passed without our seeing several Ravens during our sojourns at the forest lodge, which generally lasted till the middle of October. The carcasses of the deer killed were hardly ever attacked by the Ravens for the first twenty-four hours, even in instances in which we took no precautions to scare them, but if through any mischance we were prevented from bringing in the slain till a second day, we almost invariably found that the eyes and often a considerable portion of the haunches had been devoured.

The Raven is truly omnivorous; no weakly or wounded beast or bird is safe from his attacks. For 
eggs he has a special liking ; fresh or putrid fish, or, in fact, carrion of any sort, will always "fetch" him; and the smaller mammals and reptiles afford him sport as well as victual. Besides the above dietary, we find that in captivity our dark friends will eat almost every description of insect, besides fruit and vegetables of all sorts, raw or cooked. A Raven, taken from a nest in Northern Spain in 1876, lived for seventeen years in fine plumage and condition at Lilford, and was, with the exception of the occasional curtailment of some of his wing-feathers, allowed complete liberty. His manners were a constant source of amusement and interest to us and a wide circle of acquaintance. Intense curiosity and a curious mixture of boldness and extreme caution were the leading features of the character of "Sankey"-a name which, judging from its frequent repetition by the bird himself, he seemed to have accepted with satisfaction. In company with another Raven sent to me from the south of Spain, Sankey spent his summer days in roaming about the lawn in front of the house, where he found voles, frogs, earthworms, grasshoppers, and other provend. He almost always accompanied a friend or a stranger to a certain point on the carriage-drive, which he seemed to consider the limit of his jurisdiction. He would take any opportunity that presented itself of testing the consistency of the lower garments or shoe-leather of an unwary male of our species; but we seldom heard of his attacking a woman. At any strange dog, large or small, he "went in," and after bestowing a hearty dig on his hinder parts, used to retire to some coign of vantage and mock his foe, with an often-repeated "bow-wow," uttered in a complacent 
and sympathetic tone, which must have been peculiarly aggravating to the injured one. 'The Rooks appeared to be on good terms with these Ravens, but we noticed that Sankey seemed to have a great objection to seeing, as often happened, a Jackdaw or Starling perched on the back of a sheep, and would at once dispossess such an individual of his seat and occupy it himself. Any superfluous food was generally hidden away for future consumption, and the hidingplaces often quaintly chosen: $e . g$. we once saw the Raven carefully part the long feathers on the back of one of our Emus, insert a small fish from his pouch, rearrange the feathers, and hop off with the air of having done a very clever thing. These two Ravens used to roost regularly all the year round on the same bough of a large beech close to the house, and seemed neither to fear or suffer from any stress of weather whatever. In the early spring of 1880 they built two or three nests, but, as far as I could find out, did not lay any eggs. Poor old Sankey's successor, and companion for the last two or three years of his life, is a bird that I received from Holland, and rejoices in repeating the name of his departed ally. This Raven, whom we have named "Grip," in memory of the classic bird of "Barnaby Rudge,' paired in 1894 with an Andalucian of his species; the happy couple built a huge nest of sticks, moss, and leaves in the beech tree above alluded to, five eggs were laid, and four of them hatched. I have given away the young birds, and at this time of writing, October 1894, they are all thriving, and I trust respectively "a joy" to their owners. In spite of the wariness and caution of the Raven in a wild state, it is an exceedingly bold bird with regard to 
others, and will immediately attack any bird of prey which may approach its nest, and, as we have frequently observed in Spain, hold its own, when feeding on a carcass, amongst Vultures of various species, Kites, \&c. From a game-preserver's point of view, the Raven, though decidedly a powerful enemy, is not so pernicious as the Grey Crow, Corvus cornix ; and though, as we have above stated, the former bird has a decided liking for eggs, he does not, to our knowledge, quarter over a Grouse-moor in search of them, as the latter constantly does. 'The Highland shepherds hold the Raven in abhorrence from his undeniable habit of attacking their newly born lambs, but we know an old Highland gamekeeper who, after long experience on the moors, maintained that a pair of Ravens were rather beneficial than otherwise to game, on account of their driving away Eagles, Hawks of all kinds, and the aforesaid Grey Crows.

The Raven is found more or less commonly in all parts of Europe and large districts of Asia and N. America.

\section{CARRI O N - C R OW.}

\section{Corvus corone.}

Although our friend Professor A. Newton treats this bird as not to be distinguished specifically from the Grey Crow, Corvus cornix, and although we cannot pretend to sufficient knowledge to pronounce decidedly on such a difficult subject, we at present prefer to treat of the two birds as distinct species, as we feel no doubt they are so considered by those 
who are acquainted with their habits as obseived in Northamptonshire. We, however, strongly recommend all who are interested in the subject to read Professor Newton's remarks thereupon in the fourth edition of Yarrell's 'British Birds,' and to form their own conclusions, merely remarking that on one point, $i$. $e$. the absolute similarity of cry, vide loc. suprà cit. p. 278 , we must entirely disagree with the author. The Black or Carrion-Crow, although unceasingly and vigorously pursued to death by everyone who knows its habits, is a common bird in all parts of Northamptonshire with which we are acquainted, and is to be met with generally in pairs at all times of the year, but in wilder and less preserved parts of our country we have often observed flocks of Crows to all outward appearance behaving very much after the manner of Rooks, and coming in night after night to a roosting-place with less outcry, but with much the same preparatory aerial evolutions as their congeners. About the third week in April the Carrion-Crow builds, or returns to its old nest, its partiality for particular nesting-sites being very remarkable. We are acquainted with many instances in which a pair of these birds having been shot and their eggs or young and nest destroyed, another pair took possession of the same tree in the following spring, and if the old nest is allowed to remain it is almost always tenanted.

We have not a word to say in defence of the Carrion-Crow. His habits appear to us to be purely noxious, and neither his personal appearance, voice, or manners in captivity offer anything in extenuation of his natural evil propensities. After a flood our 
meadows are especially affected by this species; and it is curious to observe the way in which they seek for and make use of a large stone upon which to let fall the mussels, whose shells, one would imagine, they could easily break by simply fixing and pecking at them. Nothing in the shape of animal food seems to come amiss to the Crow, and their partiality for eggs is only too well known to our gamekeepers and others. We have often seen one of these birds fairly driven away by a pair of Peewits from the vicinity of their nest. As far as we could make out, both birds repeatedly struck the robber with their wings. We also once witnessed a fight between a Carrion-Crow and a pair of Partridges, which no doubt had a brood of young in the long meadowgrass close at hand; how the battle would have gone we cannot say, for we put an end to it by shooting the Crow. We have twice seen a Carrion-Crow catch a Sky-Lark on the wing and carry it off; but these Larks were both in a weak state from protracted frost. The Carrion-Crow is common in many parts of Europe, especially so, according to our own observation, in the valley of the Rhine above Cologne. In Spain it is not very abundant, but we have met with it in all parts of that country.

\section{GREY CROW.}

\section{Corvus cornix.}

In all respects, except those of plumage and voice, this bird exactly resembles the common Black or Carrion-Crow ; but with us in Northamptonshire it is an autumnal migrant, generally putting in an appearance during the first or second week of October and 
remaining till the beginning of April. It is never, I think, so abundant in the valley of the Nen as in that of the Welland, but with us its numbers are subject to great variation, and do not seem to depend upon the weather, as I have seen as many during a mild November as in severe frosts. The Grey or Hooded Crow, during its stay with us, roams the country in pairs or small parties, always preferring our large open fields and meadows to more closely enclosed localities. In the eastern counties this species is very abundant during the winter. A great number are shot, and I believe eaten, on their arrival at Hunstanton and other places on the Norfolk coast, and I have often observed, when shooting in the western parts of that county, how these birds will hang about on the flanks or rear of a shooting-party, and at once commence operations on any game which, falling at a distance, is not immediately retrieved; but their most flagrant offences against the game-laws are committed in Scotland and the west of Ireland, where they breed abundantly, and lay almost every other species of breeding-bird under contribution. In a certain rocky glen in Invernessshire, with which I was well acquainted, a pair of Grey Crows had their nest in a Scotch fir, and we found a small plateau immediately opposite to the said nest literally strewn with eggs sucked by these marauders; besides those of Blackgame, Grouse, Ptarmigan, Wild Duck, Teal, Snipe, Curlew, and Golden Plover, which they might find in some abundance at a comparatively short distance, we discovered fragments of the eggs of Song-Thrush, Wood-Pigeon, Land-Rail, Waterhen, and Grey Partridge, none of which birds breed within several miles of the nest to 
which we refer. The gamekeepers annually destroyed this nest and the Crows, but a fresh pair of these birds regularly built in the identical fork of the fir above mentioned during the nine years of our tenancy of the shooting of the district. It is a curious fact that although the present species is a winter visitor to England from the north of Europe, in almost all parts of which it is abundant in the summer, it is nevertheless the common Crow of Sardinia, Cyprus, Palestine, and Egypt. In the two former of these countries we found it breeding in numbers in low trees, the nests and eggs very closely resembling those of the Black Crow.

The Grey Crow varies greatly in dimensions and shade of colour, those which we bave examined from the south and east of Europe being smaller and lighter-coloured than our own birds; but large or small, dark or light-coloured, the habits of the bird are always abominable, and although, from the accident of its not nesting in our county, we are not exposed to the detriment from this thief to which those dwelling on the other side of the Tweed are subject, we have no plea to urge in defence of the Grey Crow, and hold him as a sturdy vagrant to be summarily dealt with at all times and in all places. We should be sorry to exterminate any bird; but this one could be better spared than any other with which we are acquainted. 


\section{7. $\mathrm{R} 00 \mathrm{~K}$.}

\section{Corvus frugilegus.}

'Ihis is another of our British birds which is so abundant in almost all parts of our Islands, and so well known to our people, and about which so much has been written, that it seems almost presumptuous to suppose that we can say or write anything new; but to the inquiring ornithologist there are still several matters in the habits and domestic economy of the Rook upon which information and explanation would be most acceptable. We imagine that there can be few districts in which this species is more common than in ours, or in which greater facility of observation of the manners and customs of this "ancient family" can be at all seasons afforded by nature to a student of bird-life. Here at Lilford, at all events, we shall not be going beyond the mark in stating the number of Rooks' nests within a radius of three miles from the house at from fifteen hundred to two thousand, and have but little doubt that the actual number may be not far from double the lastnamed figure*. If the weather is mild, our Rooks crowd into their rookeries early in February, and set about marrying and giving in marriage, the restoration of nurseries, and distribution of (family) seats, but several weeks generally elapse in incessant talk and argument, love-making, and perhaps arrangements of marriage-settlements, before the buildingoperations are commenced. We had written thus

* A very great diminution in the number of Rooks breeding in this immediato locality is very evident since the above passage was written. 
far, when, on reference to our friend Professor Alfred Newton's edition of 'Yarrell's British Birds,' we discover that we have virtually been almost quoting his words, and, although convinced that we could do no better, think it only right to acknowledge our obligation, and ask, "Is there nothing new under the sun?" To resume, and make what really is a long matter short, the eggs are generally five, sometimes six; we know of one instance in which eight were found in the same nest; they vary but little in colour, and are generally hatched in the second and third weeks of April. The appearance of the young birds at the edge of the nests, or on the boughs immediately surrounding them, depends much upon the weather: if it is mild and showery, and food consequently abundant and easily found, we fancy that the rapid growth of the closely packed young produces such intolerable heat in the nests that they will scramble out as soon as they are able to do so, whilst in the cold and ungenial weather which is now, unfortunately, so frequent during May, the young Rooks will remain huddled together in the nests till they are nearly full-fledged, and two or three of the family fully occupy all the limited nursery accommodation.

From our former experience here, we fix the 10th of May as about an average day for the Rooks to be "fit" for shooting with the rifle, but have often seen strong flyers on and before that day, and, on the other hand, have known some seasons in which hardly a young Rook could be discovered as marks for our bullets before May 15th. About the end of June (when, as a rule, the young Rooks are strong on wing and well able to procure their own living) 
the great majority of our birds leave our neighbourhood altogether for some weeks, and whither and why they go is one of the points, above alluded to, upon which "we have yet to learn." Do they visit the seaside for salt air and bathing? or do they go on a continental tour? Be this as it may, it is very certain that our rookeries and favourite rook-roosts, which are by no means always identical, are, comparatively speaking, deserted till the latter part of July or the beginning of August, when the wanderers return and swarm over our pastures in company with Jackdaws and Starlings. We notice that the main body of our Rooks always return to their roostingplace from the north-east, though many considerable parties flock in also from all points of the compass. About the beginning of October, not only all our home-bred Rooks, but almost all those from the rookeries within, roughly speaking, a radius of some miles, crowd into a wood near this house known as the Lynches, in which many hundreds of these birds are annually bred; but at the date just mentioned and during the winter few Rooks spend the night in the old bare-topped ash trees in the lower part of the said wood in which the majority of the nests are, fully exposed to our prevalent winds from west and south-west, but cluster in the elms, oaks, and few firs all over the upper portion of the covert.

In common with most of the Crow family, the Rook is omnivorous, and whilst fully admitting the immense good done by the birds in the destruction of noxious insects, we cannot defend our friends from the charges brought against them, with perfect truth, by farmers and gamekeepers of the damage done by their taste for corn, both in grain and blade, and for 
eggs fresh and incubated. It is true that we suffer more from this last propensity in a dry season than a moist one, for the obvious reason that, owing to the abundance of vegetation in the latter, the eggs of game and other ground-nesting birds are better concealed, but our Partridges especially owe their safety to this cause, and not to any lack of searching on the part of the Rooks. An observant and accurate naturalist and well-known falconer in West Norfolk used to assure me that he could detect an egg-stealing Rook at half-a-mile's distance by its manner of flight, and, being an ardent sportsman, he always preferred a flight at one of these oophagous rascals to any other that his district could then afford. We annually lose great numbers of the eggs laid by the pinioned Ducks of many species about our aviarypond from the raids of these black robbers, who will even penetrate into the nesting-hutches in which some of the wildfowl lay, and fly off with the eggs on their beaks, no doubt sucking them as they go. We also notice that our Rooks are extremely fond of walnuts and the acorns of the evergreen oak. Whether the damage done by these birds is atoned for by their good works in the destruction of insects is an open question: personally we are inclined to give the Rook the benefit of the doubt, but in such a Rook-haunted neighbourhood as ours it is certainly absolutely necessary to keep down their numbers by shooting their young pretty closely every year.

One of the most curious ornithological sights to be witnessed in this neighbourhood is a Rooks' parliament, or meeting, which, with us, generally takes place in the autumn months, and invariably in one of three special places, about an hour before the 
time for retiring to roost: in one of these spots, a portion of a meadow close to this house, we have seen some ten acres of ground so thickly occupied by Rooks that scarcely a sign of the grass upon which they were assembled was discernible from a few hundred yards' distance, whilst great numbers were collected in the adjoining trees, and many plunging headlong from great heights in the air and darting and twisting in all directions; those upon the ground were for the most part comparatively silent, but the occupants of the "gallery," if I may so call the trees, were, as is usual in similar assemblages, very vociferous. We have seen many such meetings, but never such a densely packed one as that observed one afternoon in early October some years ago in the meadow above mentioned, and followed, as is generally the case, by a heavy gale of wind. Here is another of the mysterious habits of the Rook, which has, no doubt, been observed by many, but which, to our knowledge, has never been explained. Rooks travel long distances in search of food; and I am assured that those which frequent the demesne of Powerscourt, at a short distance from Dublin, are in the constant habit of crossing to the Welsh coast in the morning and returning at evening. In most parts of Europe which border on the Mediterranean the Rook is a winter visitant and a very local one. In certain parts of Andalucia vast flocks appear in December, whilst in others it appears to be entirely unknown. From all we can learn, we are inclined to consider the British Islands the principal cradle of the European Rook, though it is recorded by Yarrell (4th edition, pp. 300,301) as breeding in various parts of Northern and Central Europe, as also 
in Asia. I have often been told by seafaring men that they have occasionally found the rigging of their vessels crowded with Rooks in foggy weather whilst voyaging in the North and Baltic Seas.

\section{J A C K D A W.}

\section{Corvus monedula.}

This amusing but most pernicious bird is extremely common in our county, and probably only too well known to most of my readers. In the hollow trees about the park and pleasure-grounds at Lilford they used to swarm at the breeding-season, till we found it absolutely necessary to wage war upon them in the interests of our garden, poultry, and game, to say nothing of those of the Barn Owl, a species for which we have always entertained a sincere respect and

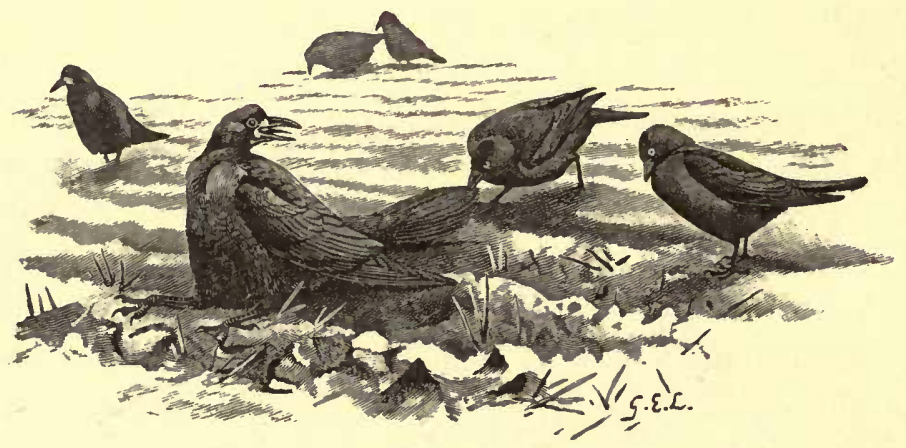

Rook and Jackdaws: Corvine Amenities.

affection. The Daws not only carried off numbers of young chickens, pheasants, and partridges, and committed havoc amongst our green-peas and other vegetables, but in several instances, to our knowledge, 
took possession of the Owls' nests, destroyed their eggs, and piled up their own nests in the cavities selected by the harmless and most useful bird of night; occasionally, however, the tables are turned, as we have previously mentioned when treating of the Barn Owl. For these and other misdemeanours we have for some years past made a practice of shooting the old Jackdaws and destroying their nests and eggs wherever we found them, with the result of decided benefit to ourselves and our neighbours. The Jackdaw disputes the palm for noisy and obtrusive impudence with the House-Sparrow, and does not, to our knowledge, compensate us in any way for his misdoings. That the Daw fulfils his duties in the great scheme of Nature I do not deny, but must confess that I am unable to discover what they may be. This bird, in our inland counties, nests in hollow trees and buildings of all kinds, and generally accumulates a vast quantity of sticks, wool, and rubbish for that purpose; but no rule is without an exception, and we have in this neighbourhood met with two instances of Jackdaws taking possession of the nests of Wood-Pigeons (Columba palumbus) situated in fir trees, and laying their eggs therein without any addition to the fragile structure of twigs arranged by the rightful owners. On our sea-cliffs many Jackdaws breed in holes and crevices, and in some localities of this kind are accused of having driven away the Red-legged Chough, better known perhaps as the Cornish Chough (Pyrrhocorax graculus), from their breeding-places; in one instance, at least, we have reason to believe that this charge is well founded. I may here mention that in Cornwall I found that the present species is often called 
Chough by the country people, and the real Chough better known as the Red-legged Daw, or Kiligrew Crow. I have often heard the name of Chough applied to the Grey Crow (Corvus cornix) in various parts of England. In open treeless districts the Jackdaw will frequently nest in rabbit-burrows and the crevices of abandoned quarries and chalk-pits. In the old walnut-tree at Pilton, of which an excellent photograph appeared in no. 10 of our 'Natural-History Journal' (not too soon, for I regret to say that it has recently lost another large branch), a great many Jackdaws are in the habit of nesting and playing havoc in the adjacent rectory garden; and here they appear to live in amity with the Barn Owls, StockDoves, and many other hole-breeding birds to which the ancient tree in question has long afforded suitable abodes. We go into no details as to the nests and eggs of this species, as they are probably well known to all our readers. In Spain the Jackdaw is a very local bird-e.g. it is almost unknown at Seville, whilst at Lomo del Grullo, some twenty-five miles from that city, we found it breeding in abundance in the ruined walls of the old royal shooting-lodge and the hollow trees in its immediate neighbourhood. In Cyprus, also, we found the Jackdaw at Famagosta only. The habits of this bird in semicaptivity are amusing, as are those of most of the Crow family, but its powers of imitation are not equal to those of the Raven, Magpie, or Jay, although in petty larceny the Jackdaw is surpassed by no bird with which we are acquainted. In winter many Jackdaws roost amongst the Rooks in our woods, and we have seen three of the former hop into a Rook's nest and settle themselves for the night. For an accurate appre- 
ciation of the character of the Jackdaw we cannot do better than refer our readers to the "Ingoldsby Legends,' where, in the description of the atrocities committed by the "Jackdaw of Rheims," they will gather that that incomparable rhymer, the author, had (probably from his long residence in cathedral precincts) become most thoroughly acquainted with the peculiarities of this species. The Jackdaw is a very strong and active flyer, and we have seen some of the best of our trained Falcons entirely beaten by these birds in a fair flight on Salisbury Downs and the heaths and unfenced fields of West Norfolk. We have noticed this species in the summer months in Northern France, Switzerland, Piedmont, Epirus, Andalucia, and Cyprus, as above mentioned. In some parts of European Turkey a race of Jackdaw occurs with a very much lighter-coloured nape than our bird, and has been described as a separate species under the name of Corvus collaris (D. Hay).

\section{M A G P I E.}

\section{Pica caudata.}

This bird still abounds in our county in spite of the constant warfare waged against it by gamekeepers. There are few of our British birds about which so much has been written, or which has been so amply treated of in fact, fancy, and fiction. As the editor of the fourth edition of Yarrell's 'British Birds' remarks, there is no doubt that in former days in England the Magpie was a very familiar species, haunting the neighbourhood of houses, as it still does in many parts of Europe; but since game-preserving and 
poultry-keeping have become general, it has become absolutely necessary to keep down the numbers of this beautiful but most mischievous marauder, and the natural caution of the genus Corvus has reached its fullest development in the once semi-domestic "Mag." We do not consider, however, that the Magpie is such a determined enemy to the preserver of game as the Jackdaw, and the present species has at least the strong plea of very great beauty in extenuation of its offences, though we fear that, in common with some other animals, it can produce no other " set off." It is true that the Magpie searches the backs of cattle for maggots, but I am assured by an experienced tenant-farmer in our neighbourhood that he considers this remedy worse than the disease, as the Magpies in the search for maggots acquire a taste for beef, and cause hideous sores which are difficult to treat. There are few things that this bird will not devour or carry off for future use or amusement, so that it is quite possible that it may occasionally destroy some noxious animals without inflicting harm upon the innocent or valuable, but our experience is that the favourite insect food of the Magpie consists of the grubs of scavenger beetles. We have no fear in this county of exterminating the Magpie as long as our vast ranges of unpreserved wood and fenced pasture-lands exist in their present condition, and furnish secure and suitable nestinghaunts for these pilfering wanderers. Our Magpie, or some very closely allied form, is found almost all over Europe and North Africa, but we never met with it in such abundance anywhere as in the north of Ireland, where we on one occasion counted two hundred and seventy-three of this species in a three 
hours' journey on an outside car. This bird is also exceedingly common in almost all parts of France, and, indeed, is the only species that would appear common to a traveller by railroad through that country who did not keep a sharp and constant lookout from the carriage windows. In Central Spain, in some parts of which the present species is very common, the Spotted Cuckoo (Coccystes glandarius) uses the Magpie's nest in the same way as our Cuckoo does those of the Hedge-Sparrow, Wagtail, and other birds in this country, and constant noisy disputes are for ever carried on between the Magpies and the above-named intruders. In many parts of Spain the place of the Common Magpie is occupied by a very beautiful allied species, the Blue-winged Magpie (Cyanopica cooki), peculiar to the Iberian Peninsula, and although extremely abundant, very remarkably local therein, we have never met with these two consorting together, or, indeed, within a short distance of each other. The Magpie, though a wary and cautious bird, is exceedingly inquisitive, and may be called into gunshot-range from a distance by a very feeble imitation of the squeal of a wounded rabbit, or the chatter of a combatant stoat, weasel, or rat, and it will also follow a sandy-coloured dog, a fox, or a cat to a great distance. Although the nest of the Magpie is usually placed at or near the top of a high tree, we are acquainted with many exceptions to this rule; and in Spain have frequently met with nests which could be examined without any climbing, and, still more, whose contents were attainable from horseback. In England this species is generally to be seen in pairs or small parties following a line of fence, and making short excursions of discovery about 
the pasture-fields, but in Ireland and other countries in which the bird is not persecuted it is not unusually met with in flocks of thirty or forty, which resort to a common roosting-place, and we know of an instance in which upwards of fifty Magpies were shot in a winter's evening by two gamekeepers in a small firplantation in Ulster. Old nests of the Magpie are much used by other birds as roosting-, nesting-, and meeting-places; and we have recorded a remarkable case of this nature in this county in the 'Zoologist.'

The nests and eggs of this species are, we presume, too well known to our readers to require description by our pen, but it may be worthy of record that we have met with more than one nest without any dome or covering, in these cases the dense thorn bushes, in the centre of which the birds had built their nurseries, rendering such protection or concealment unnecessary. In confinement or, more properly speaking, in semi-captivity, the Magpie is a very amusing bird, but his ceaseless chatter is, to our ears, most unmusical and annoying, and his thieving- and hiding-instincts have long been historically famous or infamous.

\section{J A Y. \\ Garrulus glandarius.}

This beautiful bird is exceedingly common in all parts of Northamptonshire with which we have any acquaintance, and a very great ornament to our woods and plantations. We cannot defend him from a game-preserver's point of view, and he is decidedly detrimental to the gardener, but his actions are so 
sprightly and lively, his voice capable of such infinite inflections, and his beauty so great, that with us the "Jay bird," as this species is commonly called, is a very great favourite. Shy and cunning as this bird is, his habits may be pretty closely observed at certain times of the year with a little caution and management. Intense curiosity and thirst for knowledge appear to be the principal motives of action; any unusual sight or sound attracts the immediate attention of this species, and the low alarm-note of the Blackbird, the chiding of a 'Titmouse, or the rapidly repeated "pink, pink," which announces that something has disturbed the mind of the Chaffinch, will soon bring up all the Jays within hearing. If the cause of disturbance should prove to be a dog, cat, stoat,

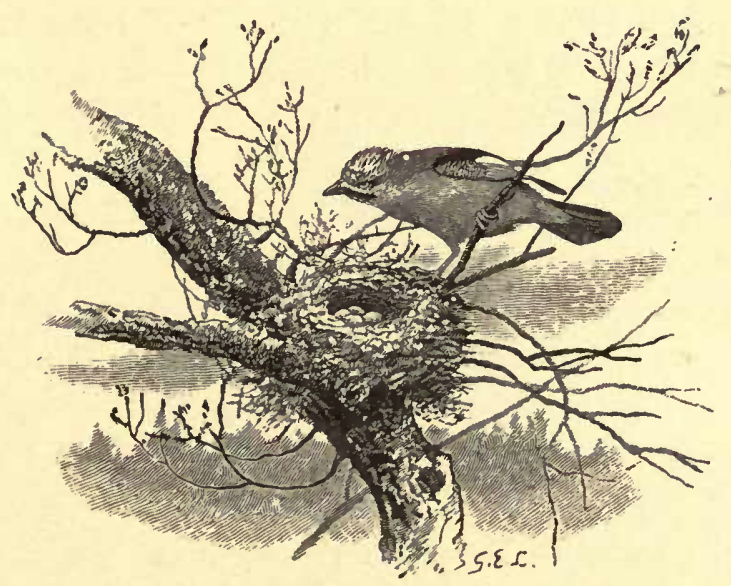

Interested Inspection.

or weasel, the Jays hop about from branch to branch, with harsh and loud cries, as long as the quadruped remains in the neighbourhood, but should they detect a human presence, they keep quiet in the most leafy 
spot they can find, and steal off silently to a safe distance on perceiving the slightest movement. In the breeding-season the Jay is not often heard and comparatively seldom seen. The nest is generally well concealed, seldom at any considerable height from the ground, a very favourite site being the dense thickets of blackthorn in our forest-district; we have also met with a Jay's nest in a dense young spruce, and often in thick hazel-coppice. The numbers of our native Jays are usually reinforced by an arrival of autumnal visitors during the month of October, but never, in our recollection, to such an extent as in 1882, when, acorns being comparatively scarce, the beech trees in our pleasure-grounds at Lilford were visited by more birds of this species than we ever saw there before.

This bird has a wonderful power of imitating the cries of various beasts and birds, and on one occasion near Madrid we spent some time in pursuit of what, from its call, we were convinced was a Common Buzzard, but turned out to be a common Jay, which had acquired the exact note of the former bird. A great destruction of this species takes place on account of the value put upon the blue wing-feathers for making artificial flies for fishing, and every gamekeeper's hand is against the Jay on account of his egg-stealing propensities, but the bird is still abundant in suitable localities throughout England and the southern counties of Scotland, but in Ireland is by no means so generally distributed and very local. We have met with this species in all parts of Europe which we have visited; it is represented in North Africa and parts of Asia by very similar and closely allied species. In captivity the Jay is a most amusing 
pet and becomes very tame. There is little trouble in keeping it in good health and condition, as in the matter of food scarcely anything comes amiss. We have found, however, that more than one of these birds in our possession preferred the eggs of small birds to any other food.

\section{S W A L L O W.}

Hirundo rustica.

The Swallow is so well known, and its habits so easily observed in town, village, and country, that we have little need to do more than record the fact that it is as common in Northamptonshire as in the other midland counties of England, its numbers, of course, varying in different summers with us as in other localities. Records of first appearances of our vernal migrants, though locally interesting, are not of any great value, for, as Professor A. Newton most truly remarks, in his description of the present species (Yarrell's 'British Birds,' 4th edition, vol. ii. p. 341), "It must be borne in mind that certain spots in nearly every district are yearly visited some days sooner than other places, even in close vicinity." We may, however, state that about April 10th is the time to look out for the first Swallow in our neighbourhood: we do not recollect to have ever seen one of this species on wing in Northamptonshire before April 6th; but in 1870 we picked up a dead Swallow on the 2nd of that month. Many curious sites for the nest of the Swallow have been recorded; one of the most remarkable that has come under our own notice was inside the wooden pent-house roofing of 
an aviary at Lilford, within a very short distance of a perch constantly occupied by a White-tailed Eagle, who appeared to take no notice whatever of the constant passage of the parent Swallows through the wire netting which covered the front of the cage; in this perilous spot five young Swallows were hatched and reared, and, for all we know to the contrary, may still live to tell the story. We do not recollect to have seen one of this species in Northamptonshire later than the first week of November, though many apparently well-authenticated instances of their tarrying into December in various parts of England have been recorded. As a rule, our first broods of Swallows leave the nests about the beginning of July, and as soon as they are strong enough on wing, and able to procure their own food, haunt the banks of the Nen principally, and roost in great numbers amongst the willows and reeds on its banks; the second broods are generally on wing in the first days of September, and about that time the early birds begin to move southward, and may be seen congregating on leafless trees, house-tops, \&c., preparatory to departure: by the second week of October the bulk of our Swallows has left us, though there are few seasons in which a late brood or two may not be found in the nest in that month; but our experience is that these very late birds almost invariably die in the nest, or very soon after leaving it. On several occasions when yachting in the Mediterranean at the period of vernal migration we have had many wearied birds of this and many other species come aboard in a breeze, and there is no doubt but that many Swallows annually are drowned, whilst on their travels, in spite of their great powers of flight. The present species is a 
common summer visitor to all parts of Europe, from Archangel to Gibraltar, and in winter visits the Cape of Good Hope. This species, and indeed all the members of the family Hirundo, are of incalculable benefit to man by the destruction of countless myriads of noxious insects, and we cannot sufficiently condemn the abominable cruelty of shooting these beautiful and useful birds for practice or amusement.

\section{MARTIN.}

\section{Hirundo urbica.}

This pretty little bird is more numerous with us even than the species last treated of, during the summer months, arriving generally a few days later than the Swallow and soon scattering all over the country. Within a very few days of their arrival these birds set about the work of nest-building; and we have often been amused at their persistent efforts to lay the foundation of their establishments against a wall to which the mud will not adhere. Long rows of nests may be seen under the eaves of the cottages in some of our villages, and not one in others which apparently present exactly the same advantages as those chosen. We have more than once noticed a vast assemblage of Martins on the gravel in front of the house at Lilford, and on investigation found that the birds were devouring minute, black, winged insects which literally covered the gravel, though we could not discover any of them on the turf immediately adjoining; it is remarkable that on one of these occasions certainly there was not a single Swallow to be seen amongst many hundreds of the present 
species. The Martin generally remains with us a good deal later than the Swallow, in fact it is by no means unusual for a few of the former to linger with us till nearly the end of November. We are inclined to think that the Martin generally lays three successive clutches of eggs, but the young of the third brood are seldom successfully reared, and many unhatched eggs may be generally found on examining a row of Martins' nests in the winter months. This species is a common summer visitor to all parts of Europe ; its winter resort appears not to be satisfactorily ascertained.

\section{S A N D - M A R T IN.}

Hirundo riparia.

The Sand-Martin, though by no means rare in our district, is very much less abundant than either of the two species last mentioned, and we are only acquainted with two nesting-localities within a considerable radius from Lilford. This may of course be accounted for by the general character of our soil, which in very few spots admits the mining-operations of this species. These birds are the earliest of the Hirundines to arrive in our country, but do not, from our own experience, put in an appearance in our neighbourhood till the Swallow and Martin have been with us for some days. The present species is, except at some of its breeding-stations, seldom to be seen far from water, and certainly seems especially to affect rivers and streams in preference to lakes and ponds. The Sand-Martin may be distinguished from its British congeners when on wing, at a great 
distance, by its peculiar hesitating manner of flight. We presume that the nesting-habits of this species are known to most of our readers, and will therefore only here state that the favourite localities for a colony of Sand-Martins are the steep sandy banks of rivers, railway-cuttings, chalk- and gravel-pits, in which the birds drive tunnels varying, it is said, from eighteen inches to nine feet in length. Our own experience has been but scanty; but we certainly never met with a nest at more than three feet from the bank, and should, from recollection, reckon the average length of perhaps some ten or twelve tunnels which we explored at from twenty to thirty inches. The work of these birds is most interesting to observe, and their rapidity marvellous, when we take into consideration the feeble instruments with which Nature has provided them. The nest is composed of dry grass with a profuse lining of feathers, and placed in a slight enlargement at the end of the gallery; the eggs, generally four or five, are pure white, very much resembling, but smaller than, those of the Common Martin. As the editor of the fourth edition of Yarrell's 'British Birds' most truly remarks, in a footnote, vol. ii. p. 357, "Those who have dng out the nests of this bird need not be reminded of the inconvenience which the operation is likely to produce from the swarms of fleas with which, towards the end of the summer, they are infested," and fleas are not the only vermin in these abodes. In districts in which the Sand-Martin is common, thousands of them collect about the rivers at the end of August, roosting in the trees on the banks, and taking their departure early in September. We have found the Sand-Martin common in suitable spots in every part 
of Europe which we have visited during the summer months, and before we had visited Gibraltar, were assured that this species was to be found there during the winter, but these supposed Sand-Martins turned out to be the Crag- or Rock-Martins (Hirundo rupestris), a species which is common in many parts of Europe, and only migrates locally from the interior to the coast during the winter months. Many instances are on record of the Sand-Martin nesting in holes of walls; and we can personally vouch for the accuracy of the case discovered by Messrs. E. Bidwell and H. M. Upcher, as quoted in the fourth edition of Yarrell's 'British Birds,' of these birds selecting heaps of sawdust as their nesting-place.

\section{S W IF T.}

Cypselus apus.

In our immediate neighbourhood we may call the Swift a comparatively rare bird, for, although a few pairs nest in the towers or steeples of some few of the numerous churches within a few miles of us, we have no recollection of ever having seen more than three or four of these birds together hawking over the river during our fishing-expeditions in July. There is no mistaking the present species for any other, its ceaseless activity on wing, the astounding rapidity of its flight, its colour, and its shrill shriek at once distinguish the Swift from any other British bird. We are not able to give anything like an accurate average date for the first appearance of the Swift in North Northamptonshire; but it seldom appears before the first week in May, and is about 
the first to leave of all our summer migrants, seldom lingering after the first week in September. Our principal acquaintance with this species was formed in Spain, where it swarms in town, village, and country from north to south and east to west, dashing along the narrow streets of the southern cities with incessant screams, and darting in and out of the gloomy recesses of the cliffs which front the Bay of Biscay. The Swift does not appear to be very particular as to locality for its nest; darkness seems to be the only absolute requisite, crevices in rocks, under the eaves of buildings, high or low, these birds make their homes, often in the faces of precipices inaccessible to man, and again under the roofs of cottages, where they can be destroyed by the enemy with no more complicated weapon than a walkingstick. The nest of the Swift is a shallow arrangement of dried grasses and a few feathers, glued into a saucer-shape by secretions of the parent birds. In a nest in our possession are many wing-cases of beetles and apparently small scales of bark; in this case very few feathers have been used. The eggs are generally three, of a dull white, and much elongated in shape; the young broods generally make their first appearance out of the nests in the second or third week of July. It is a common fallacy that the Swift cannot rise from a level surface, but we have more than once seen birds of this species take wing, with very little apparent effort, from the deck of a vessel and from the surface of a polished table. This bird is a common summer visitor to almost all parts of Europe, and, curiously enough, was the earliest of the true spring migrants observed by us at Algiers, where three Swifts put in an appearance on 
February 11th, 1878, the main body, however, not arriving till the end of March. In certain spots in Andalucia a very similar and closely-allied species, the Pallid Swift, Cypselus pallidus (Shelley), is abundant in summer. The habits and manner of nesting of this bird appear to differ in no respect from those of the Common Swift; but the Pallid Swift is an extraordinarily local species, and, although very abundant at Gibraltar and Malaga, has not hitherto been met with at Seville or, indeed, at Algeciras.

\section{N I GH T J A R.}

\section{Caprimulgus europæus.}

This bird, better known as " Goatsucker," "NightHawk," and also often called "Fern-Owl," is by no means common in the neighbourhood of Lilford, though of late it seems to be more often met with than was the case thirty years ago. We have no sandy heaths or pine-woods with patches of bracken, such as these birds love, but in the few woods in our locality in which there is any large quantity of fern a pair or two of Nightjars may be generally found during the summer, and a stray bird is now and then to be seen in the Lilford plantations at that season, but most of the recent occurrences of this bird with us have been in the early part of September in turnip-fields or on the roads, evidently on their southward migration. In many of the southern counties of England this bird is very common, and we have often seen as many as a dozen individuals in a summer evening's stroll in various parts of Devonshire, whilst the air resounded with their curious 
note, which is difficult to describe, but has been compared to the sound of a spinning-wheel. We have occasionally noticed the Nightjar during this performance, which appears always to be produced whilst the bird is at rest; but these birds frequently utter a very different note whilst flying, which the editor of the fourth edition of Yarrell's 'British Birds' likens to the swinging of a whip-thong in the air. This species generally arrives in this country in the first fortnight of May, we have found eggs on the 21st of that month: no nest is made, the eggs being laid on the bare ground, and the same spot used year after year. So much do these birds adhere to their favourite nesting-haunts that, on one occasion, in Merionethshire, on asking a lad if he knew of any "Fern-birds" eggs, he told us that he had not seen any that season, but could take us to some at once, and immediately did so, the eggs in four out of five cases being found on, or within a few inches of, the spot on which our companion had found them in previous years. The Nightjar's complement of eggs seems never to exceed two; their ground-colour is white, with a varied and beautiful marbling of various shades of brown and lilac; to our eyes they are amongst the most handsome of British birds' eggs. The flight of the Nightjar is silent, rapid, and buoyant, with constant twists whilst in pursuit of prey, which consists principally of moths and cockchafers ; in Devonshire the small chafers locally known as "fern-web" appear to be the favourite food of this species. This bird, though fond of the shade, delights in warmth, and may often be found basking upon bare stony spots in old quarries and similar localities in the full glare of the sun, nor, in spite of 
its crepuscular habits, does its sight appear to be at all affected by bright sunshine; it is very frequently found on sandy roads and paths, where it dusts itself, after the manner of the game-birds. The Nightjar generally sits lengthways, or, as a sailor would say, "fore-and-aft," on a branch, and not across it as most birds, and crouches close to its seat with the head lower than the body. We have met with this species in all parts of Europe which we have visited in the summer; it is especially common in the sandy forest-districts of Germany, but in central and southern Spain is not so abundant as the Red-necked Nightjar (Caprimulgus ruficollis).

\section{CUCKO0.}

\section{Cuculus canorus.}

This well-known bird arrives in our district generally between the 12th and 20th of April, and immediately proclaims its presence by its loud and mellow call, of which its common name with a stress on the second syllable is a very fair imitation. So much has been written on the habits of the Cuckoo by observers far more competent than ourselves, that we do not propose to go into any lengthy details concerning them, but merely state a few particulars of our own personal observations of the bird in our own neighbourhood. The valley of the Nen, where we know it best, viz. between Thrapston and Oundle, appears to have a very special attraction for the Cuckoo; its numbers of course vary in different years, but in no part of our own or any other country, with which we have any acquaintance, have we met 
with more of this species or found so many of their eggs as in the locality just mentioned. The Cuckoo is most noisy and conspicuous a few days after its first arrival, the male birds, as is the case with many migratory species, coming before the females; the latter are certainly in the minority, and the supply is apparently by no means equal to the demand; for constant quarrels and occasionally fierce encounters take place amongst the males, the vanquished generally retiring to a short distance and relieving his ardour by incessant clamour. We have been reminded on these occasions of the scenes frequently to be witnessed amongst Red Deer in Scotland in the month of October; in both cases it frequently occurs that during a hot engagement between two champions a third suitor seizes the opportunity; for these birds certainly do not pair, but the hen accepts the attentions of an indefinite number of the other sex. During these skirmishes the male bird often utters a somewhat guttural chiding note, and now and then appears to have a difficulty in getting out a full "cuckoo," stopping short at the first syllable, whilst the female occasionally produces a cry which somewhat resembles that of the Green Woodpecker when heard at a considerable distance. In our neighbourhood the nests generally selected by the Cuckoo are those of the Reed-Warbler; we have also found the eggs of this bird in nests of the Pied Wagtail, Tree-Pipit, Hedge-Sparrow, Redstart, Spotted Flycatcher, and Sedge-Warbler; a footnote appended to the description of the Cuckoo in the fourth edition of Yarrell's 'British Birds' states that the nests of no less than seventy-eight species of birds have been recorded as containing eggs of this species. 
Our conviction is that the Cuckoo generally lays her egg on the ground, and carries it in her bill to place it in the nest she has selected, as we have before stated when treating of the Reed-Warbler, and this habit has, no doubt, led to the common belief that the Cuckoo sucks the eggs of other birds, a tale of which we have never been able to meet with any authentic confirmation. The egg of this bird is, comparatively speaking, small; those which we have personally found vary little, the ground-colour being white, with a pretty close speckling of grey-brown, occasionally very closely resembling those of the Pied Wagtail in colour, but more elongated in form. We have never met, except in the instance of the last-named foster-parent, with a Cuckoo's egg which could possibly be mistaken for one of those of the rightful owners of the nest in which it was found, but it would appear that many ornithologists maintain that the Cuckoo has the power of occasionally assimilating her eggs to those of the species in whose nest she deposits them. There seems to be no doubt that the young Cuckoo very soon after being hatched ejects any other occupant of the nest; very curious details on this subject will be found in the edition of Yarrell's 'British Birds' above cited, on the authority of Edward Jenner and others: our own experience goes to prove, at all events, that the young interloper is invariably alone in his usurped home a very few days after making his first appearance. The motive which induces small birds of various species to mob and follow the Cuckno as they sometimes do is impossible to account for, more particularly because it is by no means a constant habit; and if the resemblance in shape and manner of 
flight to a Hawk were the true cause, we should expect to see the Nightjar exposed to the same annoyance. The growth of the young Cuckoo is very rapid, and it generally leaves the nest within a fortnight of being hatched. We have frequently been startled on looking into a Reed-Warbler's nest by the gaping yellow mouth of one of these youngsters, who completely filled and sometimes overlapped his little domicile, and snapped savagely at our fingers. The assiduity with which the young Cuckoo is fed and attended by his foster-parents after leaving the nest is probably well known to most of our readers, and has been previously alluded to by us when treating of the Pied Wagtail in these Notes. As far as we have been able to ascertain, the principal food brought by the deluded guardians consists of their own natural prey, gnats, small flies, and beetles; but as soon as the Cuckoo can take care of itself hairy caterpillars are undoubtedly its favourite morsels. The young Cuckoo, on leaving the nest, generally sits on a bare bough on some open spot near its birthplace, continually uttering a shrill and tedious cry. 'The old Cuckoos are silent after the middle of June, and leave us altogether in July, the young birds generally following them about the end of August; but we have often met with a lingerer in the early part of September; and in 1882 a young Cuckoo, presumably hatched in the immediate neighbourhood, was constantly seen near the boathouse at Lilford till the 25th of that month. We have had several Cuckoos in confinement, and in one instance succeeded in keeping one of these birds through two winters; this individual, after about three months of cage-life, began to pick up his own 
food, and moulted out very clean, but, though perfectly tame and very spiteful, became restless at the seasons of migration, and spoiled his plumage by constant attempts to escape; at other times he would sit stolidly on his perch, continually chirping; we once only heard him attempt to say "cuckoo," but the attempt was a grievous failure. This was the only caged bird of this species in our possession which we ever knew to feed itself, or indeed managed to keep alive for more than a few months. The Cuckoo is a common summer visitor to all parts of Europe.

\section{H OOPOE.}

\section{Upupa epops.}

The Hoopoe is one of those species which, although it cannot be considered a very rare bird in Great Britain, is not permitted to become common with us, its conspicuous appearance and its fearlessness of man rendering it an easy prize to the first idle fellow with a gun who meets with it on its arrival on our shores. The local birdstuffer will always give a price for a Hoopoe, and, we regret to say, in many instances obtains a much higher one from those collectors who attach a perfectly fictitious value to a bird (however common it may be on the continent) because it has been murdered in our own country. This species generally visits our shores in the spring: several instances of its having nested in England are on record; and were it not for the causes above mentioned, this most ornamental and harmless bird would in all probability become a common and well- 


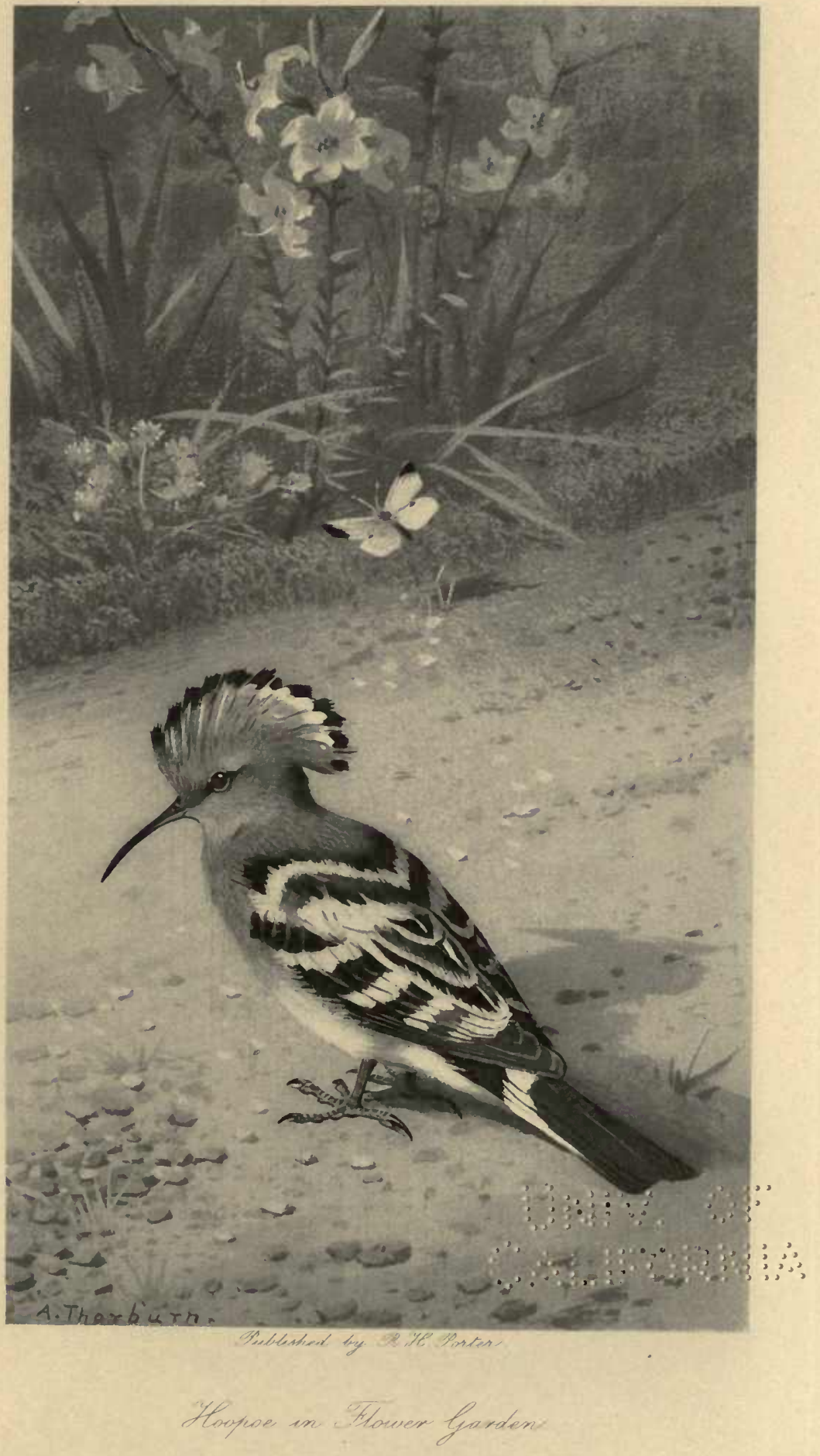


サ अ

Anom 
known summer resident, at all events in our southern and, probably, in many of our midland counties. In Northamptonshire we are acquainted with at least three authentic occurrences of this bird, the earliest in date having been kindly communicated by the Rev. J. Holdich, of Bulwick Rectory, who, in a letter to me dated February 25, 1876, writes as follows:- "Passing by coach through Denton, near Whiston, April 19, 1845, I saw a beautiful specimen of the Hoopoe which a man had just shot there; he said he had been after it for some time, and would not part with it." Mr. J. Hensman has informed me that a Hoopoe in the Northampton Museum was shot at Brixworth in August 1865; and the late Lady Lyveden often told me of one of these birds seen by her and Lord Lyveden whilst driving from Oundle to Farming Woods. This bird was first seen by my informant on the road, along which it continued to take short flights for some distance as the carriage approached, and it eventually turned off into a field adjoining the said road in the neighbourhood of Spring Wood. Lady Lyveden told me that she again saw the Hoopoe about the spot on which it was first met with on the afternoon of the same day, which was in April ; of the year I regret to say that I have no exact record, but Lady Lyveden's impression was that it was either in 1866 or 1867 . I have a recollection of having been informed many years ago by the late Ambrose Isted, Esq., that a Hoopoe had been shot near Ecton, but I have no note or particulars of this occurrence. This bird is known as a summer visitor to most parts of Europe, and is exceedingly common in Southern Spain, arriving in March and, for the most part, disappearing 
about the end of September; but a lingerer or two of this species may occasionally be met with during the winter months. The Hoopoe particularly affects groves of old hollow trees in the neighbourhood of grass-lands, and seems fond of the vicinity of houses, our experience being, as above stated, that this species is very fearless of man, but easily frightened by other birds; at all events we have often approached a Hoopoe to within a few yards without concealment of any sort. 'These birds spend a good deal of their time in strutting about on the ground, seeking for ants and other insects, with a continual nodding motion of the head, somewhat reminding one of the actions of the Pigeon family; the crest is generally carried closed, but raised at once on the slightest alarm, and almost always on alighting after a flight. We have often seen these birds probing into moist earth after the manner of the Snipe; but they seem generally to pick their food from the surface. They seldom take long flights, except when migrating, but flit from tree to tree or along roads and footpaths, of which they seem to be particularly fond, with an undulating and buoyant action. 'The love-note of the Hoopoe consists of a note resembling the word "hoop," repeated rapidly three or four times in succession; it has besides this a deep "churr" when irritated, and the young birds hiss vehemently on being disturbed in their nests, and have a short sharp cry for food. I have once or twice seen a Hoopoe cling to and climb a tree for a short distance; but I do not think that this is by any means a common habit. With regard to the nesting of this species I cannot do better than here quote a note of mine on the subject, of 
which my friend, Mr. Dresser, has made use in his work on the 'Birds of Europe'; it runs as follows:"The Hoopoe seems, as a rule, to prefer a hole in a hollow ash or willow for nesting in, but $I$ have seen a nest on the ground under a large stone, others in holes on the sunny side of mud or brick walls, one in a fissure of limestone rock, and one in a small carern. The eggs when first laid are of a beautiful pale greenish blue, but soon become stained and dirty, so that the average Hoopoe's egg is of a dirty yellow colour. In some instances I have found a good deal of nest (bents, feathers, a few small twigs, $\& c$.$) , in one or two cases no nest at all, the eggs$ lying on the bare wood, but in almost every instance ordure of some kind, human, bovine, or equine, and invariably an almost intolerable stench." We have kept several young Hoopoes in captivity for some months, feeding them principally upon ants' eggs, mealworms, flies, and earthworms : their manner of killing a worm is by pinching it between their mandibles and rapping it on the ground; when dead the worm is tossed into the mouth and swallowed with a backward jerk of the head. These birds in many instances became very tame, and were very interesting pets, but all died from the same cause, viz. the splitting of their bills and the consequent impossibility of picking up their food. The Hoopoe is fond of dusting itself, and may often be seen so doing on the sandy footpaths and bridle-roads of Southern Europe. The eggs and newly-hatched young of this species are, in Spain, often devoured by the large spotted lizards (Lacerta ocellata) which abound in most parts of that country. With reference to the habit of this bird of raising and depressing its crest, a gamekeeper 
formerly in my father's employment in Lancashire told us that one spring day many years ago a lad came running into his house, and exclaimed, "Bring th' goon, master," assuring him that he had seen a strange bird on the midden close to the cottage, with a cap on its head, which it had thrown off on his approach, and flown into a neighbouring plantation, and that he had searched diligently for the said cap, but could not find it; as they stood talking at the cottage door the bird came back to the dunghill, immediately "put its cap on again," and was, I am sorry to say, at once shot by the keeper; it was, of course, a Hoopoe. Professor A. Newton mentions nine English counties only as unstained with the blood of the Hoopoe at the time of writing his article in the fourth edition of Yarrell's 'British Birds'; but we believe that one of the nine, Warwickshire to wit, can no longer claim this purity.

Since the publication of the above article, two more instances of the slaughter of Hoopoes in Northamptonshire have come to my knowledge: the first of these was found alive with a broken wing and much damage to its tail-feathers, between Geddington and Brigstock, about May 6th, 1885, and brought to Mr. J. G. Field, of Kettering, who informed me of the occurrence. The other of these two unfortunate birds was killed at Burton Latimer on September $22 \mathrm{nd}, 1891$, and the occurrence reported to me by Mr. P. Mitchell, of Cranford. 


\section{ROLLER.}

Coracias garrulus.

My reason for including this fine species amongst the birds of Northamptonshire is the fact that on my return to Lilford from Scotland, in September 1859, I was assured by two of my sisters that they had seen and watched for some time from their windows a very brightly-plumaged bird, which was quite unknown to them, in a large beech tree close to the house; I suggested Jay, Green Woodpecker, Kingfisher, an escaped Parrot, and other more improbable birds than these, but all these suggestions were received with scorn, and one of my sisters aforesaid, on seeing long afterwards the plate of the Roller in Gould's 'Birds of Great Britain,' exclaimed at once, without any question from me, "Why that is the bird we saw in the old beech tree!" She assured me she had no doubt whatever on the subject, and her decision was subsequently confirmed without hesitation by the other sister who had seen the bird. This evidence is perfectly satisfactory to my own mind, for I cannot conceive the possibility of any other British bird being mistaken for a Roller at such a short distance as the above bird was from its admirers, and although the Roller has been but seldom met with in England at any very great distance from the coasts, where it generally meets its fate, it has been shot in Cambridgeshire and Hertfordshire, and is by no means one of the most rare of our continental visitors. Our own principal acquaintance with this species has been in Spain, Turkey, and Algeria, in all of which countries it is 
more or less abundant in summer, and of course always a very conspicuous object, more especially from its habit of sitting on bare boughs, wooden posts, and rails and telegraph-wires, whence it darts upon both flying and creeping insects, and generally returns to its perch in the same manner as our common Spotted Flycatcher and Red-backed Shrike. The Roller is generally considered and has been often described as a shy and wary bird, but our own experience is that we have always been able to procure specimens without much difficulty, and might occasionally have killed many of these beautiful birds without moving from one spot had we been murderously inclined. This species has a curious habit of turning somersaults in the air, after which performance it generally darts downwards with a harsh and grating chatter; these antics are generally carried on by the male birds while the females are sitting. The flight of the Roller is light and rapid, but on the ground its actions are clumsy and grotesque. The usual nesting-places of this bird are the cavities of hollow trees or holes and crevices in banks and cliffs, but we have known of more than one nest in ruined walls; the materials are a few twigs and some dried grass, but when the birds choose a hole in a sandy bank they seldom make much if any nest. The eggs are very much rounded, of a pure glossy white, and generally five or six in number. Besides their usual insect diet, these birds occasionally take frogs and small reptiles; we once discovered some remains of figs in the stomach of a bird of this species, but imagine that they were swallowed unintentionally with some insect food. 


\section{COM M ON KINGFISHER.}

Alcedo ispida.

We are glad to say that this beautiful bird is still common in the portion of our county with which we are best acquainted, although in some parts of the kingdom, where it was formerly abundant, we are informed that it has been almost exterminated by the craze for brilliant feathers which seems occasionally to seize upon the fair sex, a remnant, no doubt, of the barbaric taste of our ancestresses for personal adornment. Other reasons may also have to do with the destruction of this species, viz. the demand for portions of its plumage for making artificial flies, and the prejudice against this bird on account of its piscivorous habits. This latter charge cannot be denied, but by far the majority of the fishes taken by Kingfishers are of course small in size and of small value, as the bird is certainly more addicted to comparatively still waters, which afford an abundant supply of the fry of the coarser species, than to the rapid streams in which the Salmonidæ delight. The Kingfisher is said to be a very early breeder, and instances are on record of young birds having been met with out of the nest in the month of March, but in our county, as also in Oxfordshire and Devonshire, we never met with an occupied nesting-place earlier than the beginning of May. We use the expression nesting-place advisedly, for we have never found in the holes tenanted by this species anything that could be correctly called a nest, though the eggs are often laid upon the indigestible portions of food cast 
up by the parent birds. The Kingfisher usually selects the steep bank of a river, brook, or pond in which to commence its boring-operations, but we have now and then discovered the breeding-establishments of this species in gravel-pits at a considerable distance from water: the tunnel generally slopes gently upwards to a distance of eighteen inches or two feet, and ends in a slight enlargement, in which the eggs are placed; these are from six to eight in number, of a pure glossy white, and nearly round. On leaving their nursery, the young birds perch on any neighbouring boughs, and keep up an incessant cry for food for the first few days, but soon learn to catch their prey for themselves. Many authors state that the Kingfisher hovers for a few seconds before making his plunge at his intended victim, but we have personally found this to be a somewhat exceptional habit, the bird usually darting directly from its perch, and emerging immediately, flies to a bough or twig overhanging the water, and after giving the captured fish a smart blow or two against the perch, tosses it into the air and swallows it head foremost. We often notice this species making its way rapidly across country at great distances from any stream, bound to or from some pond in search of food, which although, as we believe, always taken from the water, does not consist by any means exclusively of fishes, water-beetles and tadpoles being favourite morsels. The Kingfisher flies very quickly, generally low over the water, and is a bird of comparatively solitary habits, for, although in most years several may be observed in the course of a ramble along the banks of the Nen, or a day's fishing in its waters, it is seldom that we meet with more than two in 
company, except in the early summer, when we occasionally come upon a family-party.

In common with most of our birds, this species, if not persecuted and taught by experience to avoid the sight of man, will become very fearless and even familiar. We have often watched their method of fishing from a few yards' distance, whilst sitting quietly but quite unconcealed in our boat, and on one occasion a Kingfisher settled on a fishing-rod

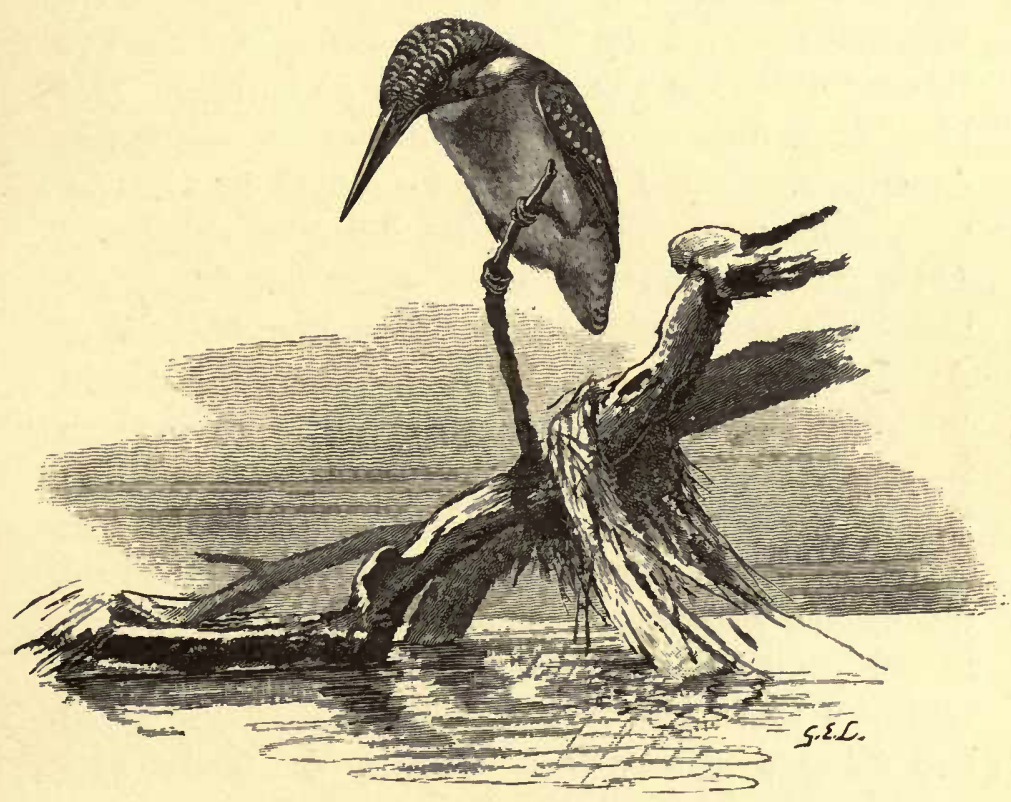

Kingfisher.

which was rested over the side of a punt in which we were at luncheon. The cry of this bird is an oftrepeated shrill scream, by no means musical, but to our own ears full of pleasant memories and associations. During severe weather, when our waters are frozen, most of our Kingfishers leave us for the sea- 
shores, the few that remain with us being often found starved to death.

The Kingfisher is tolerably common in most parts of Europe with which we have any personal acquaintance, but in some of them appears to be only recognized as a winter visitor, and we were assured, in 1883, as an extraordinary fact, that a nest of the "Ice-bird," as this species is pretty generally called by the peasantry of North Germany, had been found on the banks of the Ahr, in Rhenish Prussia, where we often observed the Kingfisher during our visits to Neuenahr in the months of May and June. This bird is not uncommon during the winter months in Andalucia. My friend Lieut.-Colonel L. H. Irby says, in his 'Ornithology of the Straits of Gibraltar,' 1875, "I have no record of its occurrence during the breeding-season, that is, not later than the end of April; the majority arrive in October, leaving in March." But we have latterly received information from an officer of the garrison of Gibraltar that Kingfishers breed near Gibraltar now pretty freely, and that two nests had been found in that neighbourhood during the summer of 1883 . We have frequently reared young Kingfishers from the nest, and found that in a large cage with a plentiful supply of small live fishes they may be kept in good health for a considerable time, but although they may, as we say in falconry, be "trained off" to feed upon worms and raw meat by placing this food in their water-pan, they never thrive long upon any other than a fish diet. In common with most piscivorous birds, the digestion of the Kingfisher is a very rapid process, and its appetite consequently voracious; this of course renders it very difficult to keep their place of 
confinement in good order, and though they become very tame and are interesting to watch, we consider that here, at least, where we have abundant opportunities of observing the bird in a state of nature, the keeping of Kingfishers costs more trouble than it is worth, and from their savage character amongst themselves, it is necessary to separate them as soon as they are fully grown.

\section{BEE-EATER.}

\section{Merops apiaster.}

This species, though an exceedingly abundant summer migrant in many parts of Southern and Central Europe, is a comparatively rare visitor to this country; and my sole authority for its occurrence within our present ornithological limits is a letter from Mr. A. G. Elliot of Stamford, dated March 4th, 1876, who therein writes:- "A pair of these scarce birds built a nest in the bank of a pond close to Kelthorpe, a hamlet to Ketton, Rutland, in the summer of 1868; the nest was composed of bones, wings, \&c. A man in the employ of C. O. Eaton, Esq., shot one bird, which I stuffed for Mr. Andrews of Ketton; the young being able to fly, got away with the other bird." This story so much astonished me that I cross-examined Mr. Elliot (who called here shortly after writing the above letter) very closely; he confirmed every word of the statement most positively, and convinced me that a Bee-eater had been shot at the spot mentioned, and passed through his hands for preservation. But as regards its nest, I must confess that I 
am still very sceptical: for besides the extreme improbability of the Bee-eater nesting in this country, the mention of bones in the said nest points at once to the Kingfisher, the present species being entirely insectivorous. The "wings" were, of course, those of insects; and so far their presence in the nest is in favour of the Bee-eater theory. It is, of course, not impossible that a Bee-eater might take possession of the nesting-hole of a Kingfisher; but I consider that this part of the story is, to say the least of it, somewhat "mixed," though I have no doubt as to Mr. Elliot's perfect good faith, nor, as I have just stated, the fact of a Bee-eater having been seen by him "in the flesh." I must add that Mr. Elliot is perfectly well acquainted with the present species, and assured me that he often saw the two birds at the spot above mentioned. Mr. Andrews having migrated to Melton Mowbray, could not be found by Mr. Elliot, who at my request went thither to seek for him. I give the whole story as it came to me; and on this evidence I trust that my readers will consider at least that I am justified in recording the Bee-eater as having occurred in the district of which I am treating.

This beautiful bird is exceedingly common in southern and many parts of central Spain, where we have formed an intimate acqaintance with its habits. It arrives in that country about the end of March or beginning of April; my friend Lieut.-Colonel Irby, in his 'Ornithology of the Straits of Gibraltar,' notes March 26th as the earliest, and April 7th as the latest, date of arrival observed by him from 1868 to 1872, and adds "The latest flight I ever saw going north was on the 7 th of May." I was in Andalucia 
in 1883, from about the end of February till neariy the end of May, and saw the first Bee-eaters of the season on April 11th, in the great plains of the Guadalquivir below Seville, but heard their unmistakable and well-nigh indescribable cry high in the air on the previous day. Soon after their arrival the Bee-eaters are to be seen all over the country, skimming like Swallows low over the plains and sometimes at a great height in the air, but always busily engaged in the pursuit of their insect food; they commit great havoc amongst the beehives, and lads are often employed to shoot at and scare them from these sweet-goods stores. We once witnessed the arrival of a large flock of Bee-eaters from Africa on the coast of Andalucia, near the town of Marbella; it was early morning on a bright day about the beginning of April 1864; we heard the chide of the birds before we could see any of them, and in a few minutes were aware of some five or six plunging almost vertically from a great height into a solitary Carôb tree of no great size, which grew some twenty yards from the sandy sea-beach; this advanced guard was quickly followed by scattered detachments of hundreds, all of which settled in the tree just mentioned. We remained for perhaps half an hour at a short distance, delighted spectators of this most interesting exhibition of bird life; during the whole of the time the Bee-eaters kept pouring into the tree, till its dark and dense foliage was completely hidden by a mass of animated and brilliant colours. The birds were evidently fatigued, and on our approaching closely to the tree only a few of them rose and circled for a minute or two in the air, settling again wherever they could find perching-space amongst their travelling 
companions. These birds resort within a few days of their arrival to their breeding-places, which are generally tunnels in the banks of rivers and ravines, sometimes in a slight elevation in open sandy ground; in this last case the Bee-eater bores down vertically for a short distance, and then runs a horizontal shaft for perhaps two or three feet to the breeding-chamber, which is merely a slight enlargement of the tunnel. In a steep bank the tunnels often run in a horizontal direction to a distance of six or seven feet; no nest is made, but an accumulation of the castings of the birds, as in the case of the Kingfisher, is often to be met with under and around the eggs, which are generally from four to six in number, of a translucent white, and very much rounded. This species seems to leave its breeding-haunts as soon as the young are strong on the wing; and after the middle of August very few are to be seen in Andalucia. Colonel Irby is, no doubt, perfectly correct in attributing this comparatively early departure to the fact that in that country all vegetation is scorched up at the season just mentioned, and there are no flowers for the bees and other honey-seeking insects to work upon. The Bee-eater often takes its prey from its perch, returning to the same spot after the capture, in the manner of the Flycatcher, Shrikes, and other insectivorous birds. We have met with these brilliant birds in Sardinia, Sicily, Malta, the Ionian Islands, Cyprus, and Algeria. 


\section{GREEN W OODPECKER.}

\section{Gecinus viridis.}

This bird, though still common throughout our county, is certainly not so abundant in this immediate neighbourhood as I remember it to have been some thirty years ago. I cannot account for this diminution in its numbers, as this district is eminently adapted to its habits, and it is not persecuted by gamekeepers or any other persons, to our knowledge, but the fact remains that during the months of August, September, and October, when I am generally at home, we seldom see or hear more than two or three Green Woodpeckers, whereas formerly at the same season of the year we used frequently to meet with a dozen or more in a day's shooting, and their cry was incessantly heard in the close neighbourhood of this house. This Woodpecker is a shy and wary bird, and anyone desirous of closely observing its habits must be very cautious in his movements, and "keep as small" as possible. The flight is performed by a series of undulations with vigorous but easy beats of the wings, the sound of which may be heard at a considerable distance. The examination of a tree for food generally commences near the ground or on the lower side of one of the lower branches, and is carried on by a succession of sudden jerks or jumps, whilst the bird darts its long tongue into every likely hole or crevice in the bark, and if conscious of being observed, keeps the tree-trunk, or a strong bough, between itself and the observer, peering round every now and then to see if all is right. The Woodpecker seems seldom to climb a tree for any 
great distance in a straight-upward direction, but ascends spirally with frequent excursions on to likely boughs, hardly ever, in our experience, sitting across a bough as most other birds do. Almost every kind of insect seems to come into the bill of fare of this species, and although the timber-beetles and their grubs, with ants, caterpillars, and spiders, no doubt form its staple diet, we have once or twice seen it dart from a tree and capture a passing moth or butterfly, and often seen it searching for "gentles" on horseflesh hung up for breeding those animals as bait for fishingpurposes. Ants and their eggs are very favourite morsels with the Woodpecker, who digs holes in the hills made by these insects and watches like a Heron for his prey. The stiff tail of these birds is used as a support in tree-climbing, but seems to be much in the way in their terrestrial explorations, and the actions of the Woodpecker on the ground are awkward and grotesque. In this neighbourhood, elms and ash trees seem to be the favourite nesting-places of the Green Woodpecker, but as long as the wood is soft and rotten at the core, they are not very particular as to the species of tree, and we have met with their nests in poplars, willows, alders, and various fruit-trees. The hole is bored with marvellous rapidity by both birds, horizontally, till the rotten wood is reached, when they turn downwards at an acute angle for some inches and enlarge the bottom of their shaft to receive the eggs; the chips of wood are thrown and carried out to the mouth of the hole, and are the best means of leading to the discovery of a tenanted breeding-hole, though these birds seem to begin upon and work at several spots for some time before finally settling upon their nursery, and from 
this habit we have frequently been disappninted in excavating into trees at the foot of which we had found a heap of fresh chips. The eggs are generally five or six in number, of a pure glossy white, and are laid on a few chips left in the hole, or on the bare wood. We have previously alluded in these notes to the frequent habit of the Starling of taking possession of the nesting-labours of the Woodpecker, and the apparent reason of the victory of the weaker bird ; an instance of this came under our special notice some years ago in our orchard at Lilford: a pair of Woodpeckers had selected an old apple-tree, and as the orchard was a good deal frequented during the working-hours of the day by the gardeners and ourselves, the birds worked vigorously from daylight till the featherless labourers came upon the scene, had another good spell during the dinner-hour, and again in the evenings from 6 P.M., when the men left off work, till dusk. The boring-operations were commenced upon the main trunk of the tree, at a height of about 5 feet from the ground. When we first discovered the work, the incision was hardly an inch deep; but on the fourth day the birds had reached the rotten wood at a distance of about $5 \frac{1}{2}$ inches, and on the seventh had ceased to work. By the aid of a pliant switch we could feel the bottom of the shaft, and twice put out the bird by so doing, but she did not desert her home, as we subsequently watched her enter and leave it on several occasions during at least a week after the conclusion of the boring-operations, till one day, on tapping the tree, a Starling flew out, and, as we soon afterwards discovered, had carried in a quantity of dry grass and feathers. Not a fragment of Woodpecker's eggs was 
found by us, nor had the Starling laid any of her own, though her nest was apparently quite ready for their reception. The Green Woodpecker appears often to pass the nights of autumn and winter in its nestingholes, and may occasionally be found therein at those seasons even in the daytime. We believe that in this county the bird is known by no other name than Woodpecker; but "Yaffil" or "Yaffle" is often applied to it in some of our southern counties, a nickname derived, no doubt, from its ordinary call, besides which note the bird has a variety of cries, for the most part harsh and discordant. This Woodpecker is, according to Yarrell, found more or less commonly throughout England, is uncommon in Scotland, and exceedingly rare in Ireland. We have met with this bird in abundance in Northern Germany, France, and Italy; but in Spain it is represented by a nearly allied and very closely resembling race, Gecinus sharpii of H. Saunders.

The young of this species may be kept alive in confinement, but require great care and attention and a variety of diet: insect food is absolutely essential to their health during their progress towards maturity, and we have found it difficult to make them take to any other; but finely chopped or scraped raw beef with soaked bread, crushed hemp-seed, and filberts will sometimes induce them by degrees to acquire a taste for fruit of various sorts. They become exceedingly tame, and are, from their quaint manners and attitudes, interesting inmates of an aviary. The ordinary laughing cry of this species when uttered more frequently or vigorously than usual was, it seems, taken as an indication of coming rain, and gained for the Woodpecker the name of "Rain-bird" 
in some parts of England; but, beyond the fact that most arboreal birds are more restless and noisy in rough than in calm weather, we have failed to verify the idea just mentioned. On this subject, and indeed on all others connected with British bird-lore, we refer our readers to the often-quoted 4th edition of Yarrell's 'British Birds.'

\section{GREATER SPOTTED WOODPECKER.}

Dendrocopus major.

This bird, although the least common of our Woodpeckers in this district, is by no means rare, though Morton, in his 'Natural History of Northamptonshire,' says of it:- "The greater Spotted Wood-pecker, Mi $i \rho a$, Arist. In ten Years Time I have seen no more than Three of them: One in Thorp Underwood Lordship, another in Brampton Wood, the Third at Oxendon." From its shy and solitary habits this species is more frequently heard than seen, and even its ordinary note, a sharp monosyllable, though loud and unlike that of any of our own common birds, often passes unnoticed by the many who are not acquainted with the bird. In this neighbourhood we generally meet with this Woodpecker on the outskirts of our large oak-woods in the spring and summer, but it is a great wanderer, and when our trees are bare of leaves it would be difficult to say where there is not a chance of seeing or hearing a Pied Woodpecker, by which name it is commonly known hereabouts. In general habits this bird much resembles the Green Woodpecker, but is, as mentioned in Yarrell's 4th edition, less often to be 
seen on the ground, althuugh we have seen it more than once engaged upon an ant-hill, and it is certainly more addicted to fruit than that species. With reference to the loud jarring noise produced by some of this family of birds, as it has only once happened to us to see the present species in the act of producing it, we propose to treat of it in the next article.

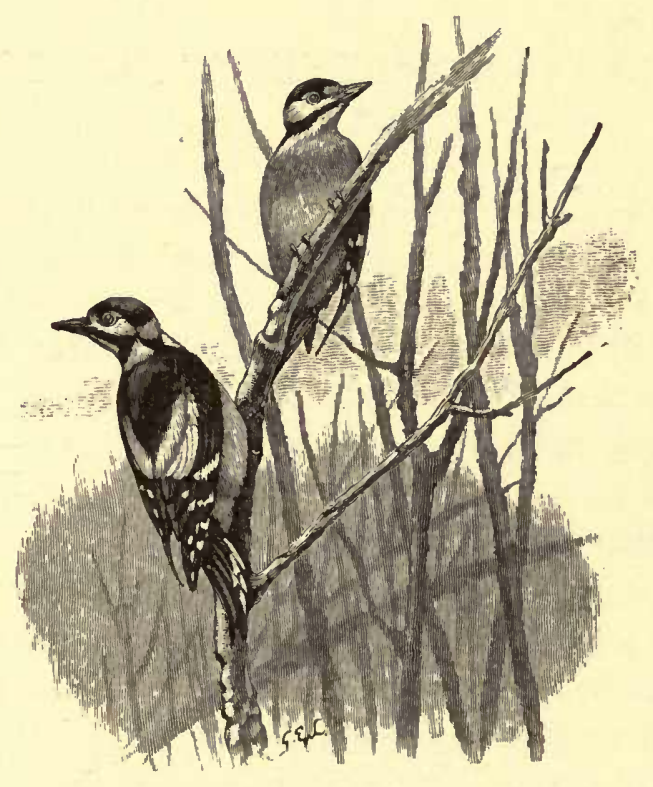

Greater Spotted Woodpecker.

Though two or three, perhaps more, pairs of this species undoubtedly breed annually within a radius of three miles from this house, we can only call to mind three instances of the finding of occupied nesting-holes therein. The latest of these discoveries was made by one of our gamekeepers on July 17th, 1883 ; the hole was in an oak tree at about 30 feet from the ground, and contained three well-feathered 
young birds. The other two nests were also in oaks, and contained respectively three and four eggs, which are of a pure white, smaller, of course, and rather more pointed than those of the Green Woodpecker *. We have reason to believe that the present species suffers to a greater extent than the preceding from the acquisitive propensities of the Starling, and in the year above mentioned heard of an instance of this "forcible entry" into a hole made by these Woodpeckers near Kingston, Surrey. Besides the names of "Greater Spotted" and "Pied" Woodpecker, we have heard Northamptonshire gamekeepers mention this bird as "French Pie" and "Whittle," which latter name is also applied in some counties to the Green Woodpecker. The young of this Woodpecker are much less difficult to keep in confinement than the species last treated of, as they take readily to a fruit and vegetable diet and thrive thereupon; they become very tame, and if set loose in a room will examine the furniture closely and methodically, and clamber over the clothes of their keeper, search his pockets for food, and come down from the cornice or top of book-shelves, pictures, \&c. at once on the offer of a fly or meal-worm. We have met with this species in various parts of France, Northern Germany, Italy, Spain, and Switzerland, in some parts of which country it seemed to be more abundant than in any other localities with which we have any acquaintance. In our own country we have noticed this bird in Middlesex, Herts, Bedfordshire, Oxfordshire, Hampshire, Norfolk, Suffolk, and Devon;

* Since the year abore mentioned, I have heard of one or more nests or young broods of the present species in the neighbourhood of Lilford, annually for ten years. 
it appears that it becomes more scarce in our northern counties, and in most parts of Scotland is decidedly rare as a resident, but the fact of its autumnal or winter migration to the northern portions of the kingdom seems to be well established. It is, as we have previously stated, at all times a wandering and restless bird, and adapts itself to any sort of locality as a halting-place, but from our own observations we should say that its favourite haunts are evergreen forests and woods in which old birches and alders abound.

A very closely allied species, the Middle Spotted Woodpecker, Picus medius (Linn.), has been admitted by some authors into the list of British birds; but it appears that this bird has no real claim to be therein included (vide A. Newton, Yarrell's 'British Birds,' 4th edition, vol. ii. pp. 483, 484); and the same observations apply to the Black Woodpecker, Picus martius (Linn.), of whose occurrence in our county we have a report.

\section{LESSER SPOTTED WOODPECKER.}

Dendrocopus minor.

This little bird, though considered rare in many parts of England, is certainly now the most common of our three species of Woodpecker in this neighbourhood, and we have observed it in every part of our county with which we have any acquaintance, though from its small size and comparatively silent habits in the summer months, its presence may often remain a secret to those who are not specially interested in ornithology. In the first sunny days 


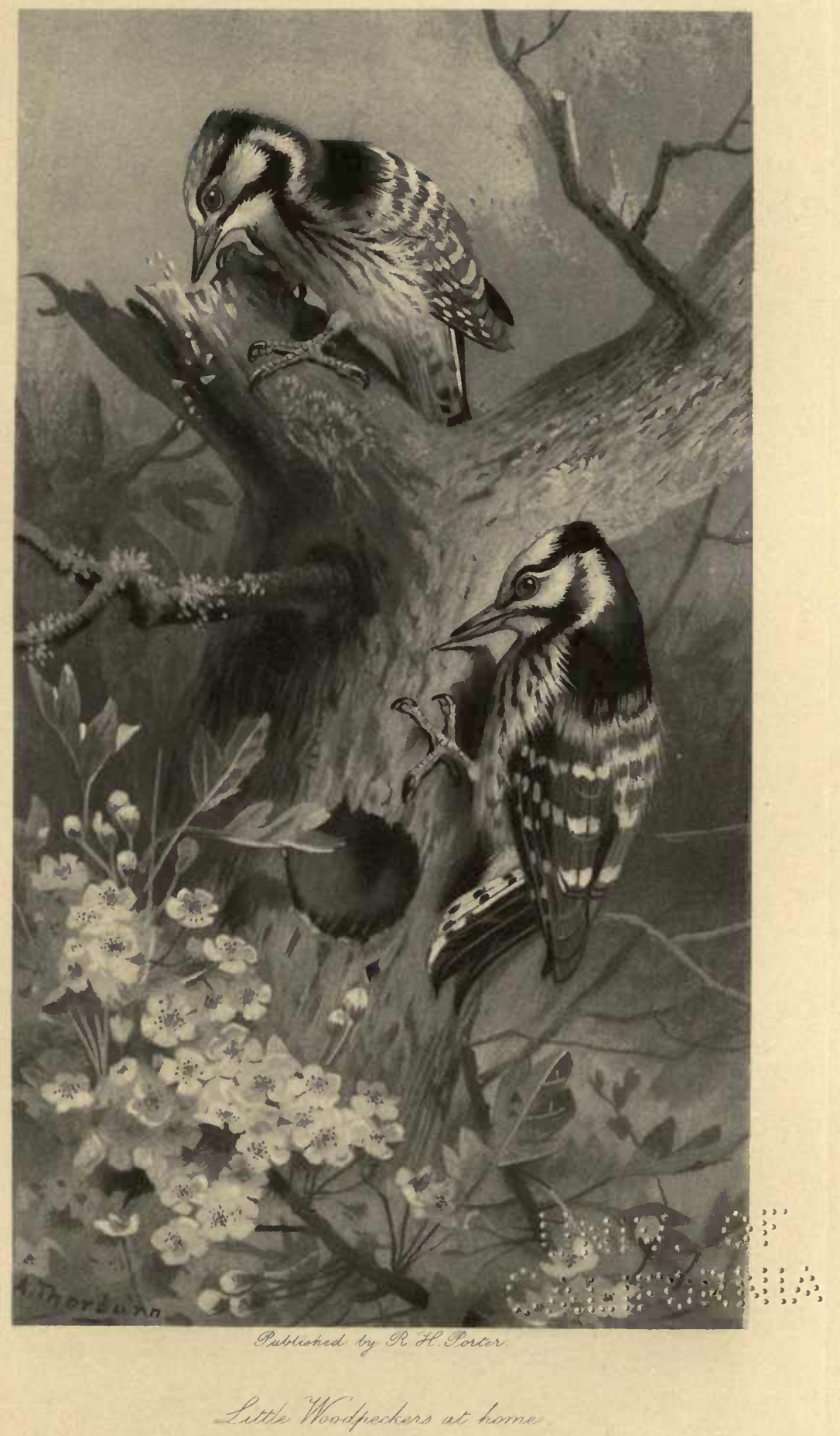


\% आओ क 
of February, and sometimes even earlier, the loud jarring noise produced by this species may be heard amongst the tall elms and other trees closely surrounding Lilford, often proceeding from two or three birds at the same moment, and continued at intervals from daylight till dusk. From long and close observation we long ago convinced ourselves that this noise is a call, and has nothing to do with intentional disturbance of insect food, as has often been supposed and stated, nor is it produced, as we with many others formerly imagined, by the rapid vibration of the bird's beak in a crack of rotten wood, but simply by a hammering or tapping action which the human eye cannot follow; on a calm day, or with a light favouring breeze, the sound thus produced may be heard at a distance of quite half a mile or even more.

This little Woodpecker is an eminently pugnacious bird, and we have been much amused at the pertinacity with which it will attack Nuthatches, Titmice, Tree-creepers, and others of its own species, and probably sex, which may encroach upon or near to its favourite rotten boughs-generally, in this immediate neighbourhood, the dead tops of tall elms; but the alder seems also to be an often-selected "pleasaunce"; and the island between our stone bridges at Lilford, which is the home of many trees of that species and horse-chestnuts, has been the principal scene of our researches into the manners and customs of this interesting and pretty bird. In this spot, on a fine morning in February or March, one may be certain of hearing the hammering in a few minutes, and as certain of very soon hearing it answered, either in a similar fashion or by the rapidly-repeated 
monosyllable "tweet, tweet." Both sexes produce both sounds, as we have proved by shooting and dissection. With a little caution we have repeatedly approached to within a few yards of the bird or birds at this time of year; but so marvellously rapid is the hammering action of the head that it was only by the aid of a field-glass that we satisfied ourselves as to the means by which such small operators produced such a resonant result. We have once or twice seen a pair of these Woodpeckers " in coitu" towards the end of March, but never heard of eggs in their nestholes before the last week of April. The preparation of the breeding-places seems to be carried on in exactly the same manner as by the other British Woodpeckers: no nest is made. The eggs average from five to eight in number, and are of a pure glossy white. The young of this species may often be found in their nurseries long after they are able to fly and take care of themselves. We cannot venture to say whether a second brood is ever produced or reared, but the first brood is sometimes to be found late in July. Old fruit-trees, poplars, whitethorns, willows, birch, alders, and elms are certainly the favourite breeding-localities; the selected spot is generally at a considerable height, and, from the tenuity and rottenness of the chosen bough, it is often exceedingly difficult to obtain the eggs unbroken,

"Little Woodpecker" and "Hammer-bird" are the only names which we have heard applied by our county-people to this species; but "Barred Woodpecker" is, to our minds, the best and most distinctive appellation; our only reason for not using it at the head of this article is that it is not so commonly used or known as it deserves. We believe that this 
bird feeds exclusively on insects, and we have never heard it accused of any depredations in orchards or on fruit of any kind. We have never kept any of these Little Woodpeckers in confinement, and every attempt to do so that has come to our knowledge has resulted in disastrous failure, although, no doubt, it is to be done. The great difficulty with all purely insectivorous birds is, of course, in the first place, the procuring a constant supply of their natural food or an acceptable substitute for it, but it appears to us that besides this difficulty, which may in some instances be conquered, it is absolutely essential to their health that they should have a considerable amount of exercise in seeking for their food, and, except in large open-air aviaries, this is not easily managed. We have met with the present species in France, Northern Germany, Italy, Switzerland, European Turkey, and Spain, but nowhere in such abundance as about lilford.

\section{W R Y N E C K.}

Yunx torquilla.

This, though never, in our experience, very abundant in our neighbourhood, is a tolerably common and well-known spring visitor, generally making its appearance within a few days before or after April 10, and immediately announcing its presence by a cry which bears a resemblance to that of the species last described, and a still greater resemblance to that of the young Hobby (Falco subbuteo). From its arrival about the same time as the Cuckoo this bird has gained the nickname of "Cuckoo's mate" in many if 
not most parts of England, but our country-people are not, as a rule, very discriminating in ornithology, and hereabouts we have heard the epithet above mentioned applied to the Titlark, Pied Wagtail, and any other small birds, except the Swallow family, which may be seen following a Cuckoo in the spring season, a habit that, as far as our own observation goes, does certainly not extend to the present species. Morton, in his work on our county natural history, mentions the Wryneck as "not an uncommon bird in the northern Part of the County near Market Harborough in the Spring Season," and adds, "What becomes of it in the Winter I know not." The migration of birds was, at the time when our author wrote, a very great puzzle to observers, and, in spite of the light thrown upon the subject since his day by many very competent writers, still remains a somewhat mysterious matter, concerning which we have all yet much to learn. The fact of the migration to and from our Islands of many species is now well established and commonly known, but the courses, causes, and variations of these travels, and more especially those of local migrations, are subjects upon which all lovers of birds must wish for full and accurate records. No correct observations of the habits of birds, however apparently trivial, are without their value.

'To return to our bird, the Wryneck is, although a common species in many parts of England, comparatively seldom seen, and though constantly heard in April, May, and June, requires to be looked for, as it principally haunts leafy trees, and from its quiet colouring may often be mistaken for another species. Its principal food certainly consists of ants and their 
pupæ, but it will eat almost any of our common insects, and searches the bark of trees by climbing, after the fashion of the Woodpeckers; the tongue is of extraordinary length, nearly cylindrical for some distanee, ending in a hard sharp point, and covered with a glutinous matter, to which the insect prey adheres. The flight of the Wryneck resembles that of the Woodpeckers, but is apparently less laborious; its actions and attitudes on the ground are somewhat awkward, on account of its short legs and its habit of keeping the stiff tail "cocked" at an angle to the body. The Wryneck does not, indeed cannot, bore into trees to make nesting-holes, but takes possession of the labours of Woodpeckers or any other cavities in trees which may suit its views, and though, as far as we know, it never makes any nest for itself, it will lay on the materials collected by other hole-nesting birds, especially, in this neighbourhood, the nests of the Tree-Sparrow, giving a decided preference to the hollows of old fruit-trees and pollard willows. The eggs are pure white, and, according to Yarrell (4th edition), vary from six to ten in number; from our experience we should say that seren is about the average, but we have found nine, and once eleven; they may be distinguished from those of the Barred Woodpecker by their larger size and a slight difference in texture of the shell, but are quite similar enough to be often labelled by careless egg-collectors as belonging to that species. The Wryneck appears to be more or less common throughout England, but scarcer in our western counties and in Wales than elsewhere, rarer in Scotland, and has, according to Yarrell (edition suprà cit.) only once been recorded as occurring in Ireland. The name Wryneck is 
derived from the curious manner in which this bird twists and writhes its head and neck when handled or irritated. We have more than once caught the bird in its nesting-holes, and found that, after vehement snake-like contortions, ruffling the feathers of head and neck, and some vicious pecks at our fingers, it would feign death, but take the first opportunity of escape. An instance is quoted in Yarrell in which no less than forty-two eggs were taken at various times in one summer, between May 29th and July 13th, from a nest of this species, and in the following year as many more from the same hole. We have met with the Wryneck during the summer in France, Switzerland, Italy, N. Germany, Spain, Algeria, and European Turkey, in which lastnamed country we twice met with it in winter.

\section{RING-D OVE OR WOOD-PIGEON.}

Columba palumbus.

To some at least of our readers we feel sure that the first of the above designations, as applied to the well-known subject of this article, will be a surprise, as the term Ring-Dove is very generally applied to the small fawn-coloured Dove with black collar. (Turtur risorius), so commonly kept in a domestic state in this country, but not an indigenous British bird: we have, however, ancient authority for so calling the present species. We have a good number of Wood-Pigeons breeding every year with us, about an average number, perhaps, for an English non-coniferous district, but in a good season for beech-mast and acorns we are generally visited by 
many hundreds, occasionally by thousands, of these birds from the north and east on their southward migration, about the second or third week of October. The stay of these travellers seems to depend upon the supply of the above-mentioned food, and of course on the weather; a few days of severe frost and snow drive them off to the southward, and although during a continuance of such weather we may be visited by an occasional passing flight of these Pigeons, they seldom linger for more than a few days. Our native WoodPigeons seldom entirely leave their birthplace; though the southward migration carries off more or less of them, some always remain, and feed, apparently principally, at our bean-stacks and on the scanty turnip-tops left by the penned sheep. In open weather few vegetable productions come amiss to the Wood-Pigeon, and we fear that this bird cannot be ranked otherwise than as detrimental to the agriculturist. The capacity of the Wood-Pigeon's crop is marvellous; the thin and delicate membrane of which it is formed seems to stretch like a sheet of india-rubber. The Rev. John Holdich, of Bulwick, has supplied me with a note from his Journal, dated December 2, 1837, to the following effect:- "Payne, the keeper at Dingley, lately killed a Wood-Pigeon in Brampton Wood, which had in its crop six dozen (72) acorns; he strung them, and made a string of about 4 feet long." We have ourselves taken 87 beans and a few fragments of turnip-tops from the crop of one of these Pigeons which we killed as it came to roost in one of our plantations some years ago, and have found at various seasons, besides the food above mentioned, wheat, barley, oats, peas, beech-mast, ivy-berries, haws, yew-berries, the pulp of turnips, 
beetroot, and mangold, young clover-leaves and seed, and a small onion-like bulb of which we do not know the correct name. We hold the flesh of this species in high estimation for the table, and our county affords but little better real sport than WoodPigeon shooting, for as everybody knows, this bird, though very tame and familiar in the nesting-season, is one of the wariest of animals at other times, and he who wishes to make a bag of these Pigeons between October and March must have all his wits about him, and "shoot straight" and quickly. There is, of course, no art in waiting well concealed and shooting the birds as they settle to roost on trees or to feed upon the ground, but though this method of slaughter has its attractions, the real "cream" of shooting is to select a comparatively open spot in a wood or plantation frequented by Wood-Pigeons in the morning, and kill or try to kill them as they dash over the tree-tops. My friend Mr. Hunt, of Wadenhoe, brought the shooting of wild Pigeons in this neighbourhood to the rank of a science, of which he was a most highly accomplished professor, and from his constant residence at Wadenhoe, his rapid and accurate insight of the habits of birds, his activity, and "straight powder," during several years, destroyed very large numbers of these excellent birds; on one evening in March he killed seventy Wood-Pigeons in about two hours, all on the wing, over one of our plantations, and some forty in the same way near the same spot on the following day. At certain times of the year many Pigeons may be decoyed on their favourite feeding-grounds by "stales," $i$. $e$. wooden or stuffed Pigeons, and Mr. Hunt most successfully introduced and carried out this method in this neighbourhood. It appears to 
us that the Wood-Pigeon, in the long days of August at all events, has three regular feeding-times, viz.-an hour after daylight, from noon till about 2 P.M., and again in the late evening. Hereabouts they give a decided preference to fields of peas and barley, and by concealing one's self amongst these crops, or in the line of flight from the woods thereunto, great execution may sometimes be done, especially at the beginning of harvest before the crops are carried : a few of the wooden decoys above mentioned, judiciously placed in conspicuous positions upon the stooks and on the mown stubble, will generally draw the Pigeons and afford very pretty shooting; it is a remarkable fact that many more old birds are thus killed than young. In hot weather many WoodPigeons may be shot at and about their drinkingplaces; but at the ponds in the pasture-lands we find that the horses, sheep, and horned cattle will invariably knock down the stales, and much time is lost in driving off these thirsty and inquisitive beasts. The Wood-Pigeon often has eggs in the first week of April, and generally rears three, sometimes four, broods in the year. We have once or twice put one of these birds off her eggs in March, and often in October. The nest and eggs are probably too well known to my readers to require description. The nests are built, to use a somewhat vague but expressive phrase, "almost anywhere," high and low, well concealed, and conspicuous to every passer, in thin-limbed beeches, dense sprucefirs, ivy, hawthorns, pollard willows, brambles, in fact no boughs or twigs that will support the simple platform of sticks seem to come amiss to these birds, and we have several times found their nests built upon old ones of other species, such as Thrushes, 
Blackbirds, and Jays, besides upon the abandoned dreys of the squirrel. If taken young enough from the nest, the Wood-Pigeon will become very tameindeed, we once had one sent to us from Spain whose familiarity amounted to impudence; he would settle on the heads of his human friends, and peck vigorously at them if not taken notice of, and attack any dog that came into our room; but utterly. declined to act as a decoy to his wild relations, as, on being pegged down on the ground with a stout tether, he would at once squat close, and remain as little conspicuous as the locality allowed. We have met this species in every part of Europe which we have visited; many are taken on their passage over the passes of the Pyrenees by means of hanging nets, into which they are driven by means of a wooden imitation of the Goshawk whirled with a long string in the air as the Pigeons come up the mountain's side. In this neighbourhood, as we have previously mentioned in these notes, many Wood-Pigeons are killed by Sparrow-Hawks, and the Peregrine Falcon is also a deadly foe; they have another enemy in our squirrels, who play havoc with their eggs and callow young.

In the severe weather of the end of 1870 and the month of January 1871, the oak-woods in our neighbourhood, being full of acorns, were visited by tens of thousands of travelling Wood-Pigeons, many more than I had ever previously seen together, but the Wadenhoe gamekeeper, who well remembered these marvellous flocks, sent me word in January $189 \pm$ that the Pigeons then frequenting the woods on that manor were as "five to one in the year of the French war," to which I have just referred. 


\section{S T OCK - D O VE.}

\section{Columba ænas.}

This bird, which is generally known hereabouts as Rock-Dove, is always more or less common with us during the spring and summer, but the great majority leave us at the first severe frosts of October, to reappear in February or the first days of March. In general habits this species much resembles the Wood-Pigeon, but differs from that bird in the selection of its nesting-sites,-usually, in this neighbourhood, the cavities of ash and beech trees, holes in old walls, and beams of our church-belfries; in open countries the Stock-Dove often makes use of deserted rabbit-burrows, and, strangely enough, in this district, with its abundance of hollow trees and ruins, we have several times found the eggs of this bird in holes scratched by rabbits at the main roots of our ash and elm trees. Two or three pairs of Stock-Doves might always be found nesting in the ivy-clad crannies of Barnwell Castle in our birdnesting days, and a pair used to nest in the belfry of our parish church at Achurch, from our earliest recollection till the restoration of the church-steeple some thirty years ago. 'This bird appears to us to be more addicted to green food than the Wood-Pigeon, but it is also very fond of beech-mast; it is easily decoyed if the shooter is well concealed, but is by far the quickest-sighted bird of our acquaintance, and, from its marvellous power of vision and rapid twists in the air, by no means so easily brought to bag as its heavier congener. In the pairing-season, early in March, the hoarse guttural note of this bird may 
be heard in every direction about the house at Lilford, and the males are often to be observed mounting in the air with loud flapping of the wings and gliding for a few moments before pitching into their favourite elm trees, as is also the common habit of the Wood-Pigeon at the same season. In the hollows of our old trees the Stock-Dove seldom makes much, if any, nest, but lays its eggs on the bare wood; in walls and rabbit-burrows we have generally found a slight nest of fine fibrous roots. The eggs, two in number, are rather smaller than those of the Wood-Pigeon, which they otherwise exactly resemble.

This bird usually rears two or three broods, and we often find fresh eggs in September and October. On the south coast of Devon the Stock-Dove haunts the ivy-and bramble-clad faces of the sea-cliffs and nests amongst this vegetation; we could not, however, discover that it haunts the caves and crevices which on many coasts are the favourite resort of the true Rock-Dove, Columba livia, for which bird the present species is often mistaken, but may be readily distinguished by its larger size and the absence of the white patch above the tail, which is always conspicuous in the smaller bird. We have no record of the occurrence of the Rock-Dove in Northamptonshire in a wild state, though many dove-cotes in our neighbourhood are tenanted by a very nearly pure race: it appears, indeed, that in our Islands the Rock-Dove haunts exclusively our rocky sea-coasts, and is seldom found at any great distance therefrom, but in Spain, and many other mountainous countries, vast numbers of this species breed in inland cliffs and caves. The flesh of the Stock-Dove is excellent- 
superior, to our taste, to that of the Wood-Pigeon; and we can confirm in every particular the account given in Yarrell of the custom of the warreners of West Norfolk and Suffolk of hunting for the young doves with dogs trained for the purpose, and making "a very good thing" by extracting and selling them. In most parts of the south of Europe with which we are acquainted the present species occurs as an autumnal migrant, but in Rhenish Prussia we found it sparingly during the summer in the neighbourhood of Neuenahr.

In April 1894 a pair of Kestrels took possession of, and reared a brood in, a hollow ash tree in the park at Lilford, upon a nest in which a Stock-Dove had laid an egg.

\section{TURTLE-D O VE.}

\section{Columba turtur.}

This species, which was entirely unknown in the neighbourhood of Lilford in our school-days, has gradually become a regular and sometimes abundant summer visitor to our district, and our country people are all now well acquainted with the "Little Brown Dove," as they usually call the subject of this article. The 'Turtle-Dove arrives with us generally very late in April or in the first week of May, and resorts at once to the old hawthorn bushes and the willows by our rivers and brooks, which are its favourite nestinglocalities, though it will build in all sorts of situations which afford quiet and concealment. The nest is an artless platform of a few twigs; the eggs, in common with those of all the species of this family, are two in 
number, and pure white. The first brood of young are generally able to take care of themselves by the third week of June, and flock together in search of food in our pea- and clover-fields. The Turtle-Dove appears to us to be almost omnivorous as regards the vegetable productions of our district, but is certainly more beneficial to the farmer than either of the two last-described species, as we have found the crops of several of this species killed in September entirely filled with the seeds of various weeds, and twice have found the remains of small snails and caterpillars amongst the mass of vegetable matter.

'The flight of this Dove is swift and very graceful, and its note, though not musical, is pleasant and suggestive of summer. We had more than usual of this species during the summer of 1883 ; the last seen by us was on September 28th, but, as a rule, they leave us before the middle of that month. The Turtle-Dove is more or less abundant in all parts of Europe with which we have any acquaintance, and is one of the birds which most commonly alight wearied, at the season of migration, on the rigging of vessels in the Mediterranean. In our own country this bird is gradually extending its breedingrange northwards; but, according to the 4th edition of Yarrell's 'British Birds,' the nest has not yet been discovered in Northumberland or over the border. In Andalucia the arrival of the Turtle-Dove is looked for in the spring almost as eagerly as that of the Quail, and parties of shooters sally forth on Sundays and saints' days, equipped in green, and, posting themselves amongst the bushes which fringe the rivers and brooks in that thirsty country, keep up a constant fire upon the passing Doves, which are by 
no means particularly easy to shoot; a vast number of cartridges and a considerable quantity of tobacco are expended, and a long and "happy day in the country" spent to some profit, for there are few better birds for the table than the Turtle-Dove. Is this a greater waste of time than shooting Pigeons from traps surrounded by a crowd of betting ruffians nearer home?

\section{PALLAS'S SAND-GROUSE.}

\section{Syrrhaptes paradoxus.}

In Prof. A. Newton's exhaustive article upon the irruption of this Asiatic species into Europe, published in 'The Ibis,' 1st series, vol. vi., will be found a note to the following effect:- "Peterborough, $15^{\prime} \mathrm{W}$. One or two killed in May or June. No other information. Mr. T. H. Allis, 'Zoologist,' p. 8724." In reply to my enquiries concerning these occurrences, I received from Mr. Bodger, Secretary to the Peterborough Natural History Society, the following extract from the 'Peterborough Advertiser,' of June 20, 1863:-

"Rara Avis.-By some singular freak, flights of Sand-Grouse from the steppes of Tartary have recently visited this country, and even manifested a disposition to remain here. One was shot in 'Thorney Fen, where two or three more are believed to be still at large, and it is to be hoped will be left undisturbed. Mr. Holywell, of Wentworth Street, has two, which he has been stuffing."

The above is the only information which I have hitherto been able to obtain concerning the occur- 
rence of this singular species within our limits. Having no personal acquaintance with this bird in a wild state, we must refer our readers to the article above mentioned, and also to that by Mr. Henry Stevenson, in his 'Birds of Norfolk,' vol. i. pp. 376404 ; in these excellent papers will be found full accounts of the occurrences of this wanderer in our own Islands and on the continent of Europe, as well as details of its habits in its native haunts in the vast plains of Asia. We have a fine pair of this species, stuffed, in our collection, which were obtained near Great Yarmouth in the summer of 1863.

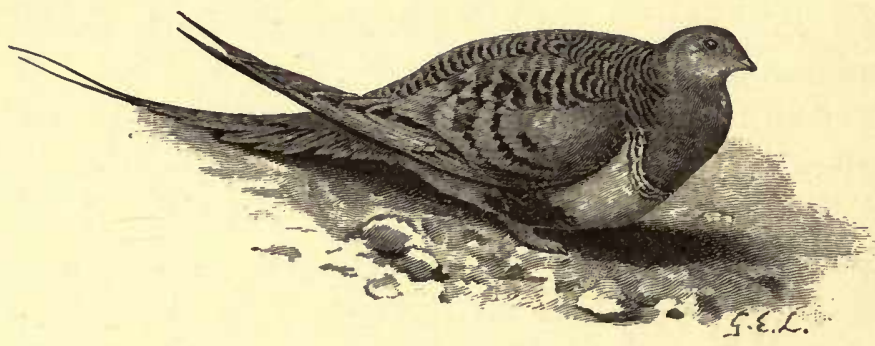

Sand-Grouse.

We are well acquainted with the two European species of Sand-Grouse, viz. Pteracles arenarius and $P$. alchata, both of which are common in many parts of Spain, but have not, as yet, been included in the ranks of British birds. The habits of Pallas's SandGrouse appear to resemble closely those of the other species of the family, all of which are lovers of treeless wastes, remote from the habitation of man.

Since the above article first appeared in print, this country has again been visited, in 1888, by large numbers of Pallas's Sand-Grouse, and I here record the meagre information that has reached me as to its 
occurrence in Northamptonshire during that year. At the close of the year above mentioned, Lord Burghley informed me that two Sand-Grouse had been killed during the previous summer upon Lord Exeter's property near Stamford, and put me into communication with a gamekeeper named John Munton, who in reply to my enquiry wrote, under date of February 4, 1889 :- "Twelve of these birds were first seen in a field on the Southorpe Mill Farm on the last day of May, 1888, and again on June 1st; on this latter day two of the birds were shot by a boy in the employ of the occupier of the farm, the others were not seen again." The writer subsequently sent me the wings of one of these victims. My deeplylamented friend and former neighbour at Wadenhoe, Mr. G. E. Hunt, called at Lilford on the evening of July 29, 1888, and reported having just seen a solitary Sand-Grouse in the meadow below Wadenhoe House. This bird passed within fifteen yards of my informant, flying comparatively slowly, and appeared to have its feet clogged with clay; it "chuckled" loudly as it passed my informant. On July 31st three birds, that, from the descriptions given to me, can only have been Sand-Grouse, were seen flying over the park at Lilford by one of our gamekeepers, and later, on the same day, by Mr. Hunt's keeper near Wadenhoe. On August 15 I was assured by Mr. W. Edwards, who has a fair acquaintance with British birds, that he had that morning seen three Sand-Grouse between Achurch and Thorpe Waterville. Mr. C. F. Dyer, formerly of Irthlingborough, informed me, by letter, that whilst out Partridgeshooting with some friends in that neighbourhood, on September 7 th, 1888, he twice flushed and distinctly 
recognized a solitary Sand-Grouse, which bird, as I have little doubt, owed its life on this occasion to the prompt intervention of my correspondent. I consider such a rare example of proper feeling and humanity as well worthy of record, still more so of imitation. With regard to 1889 , the 'Northampton Daily Chronicle' of January 19th contained the following paragraph from Mr. Wm. Bazeley of that town:"A fine male specimen of Pallas's Sand-Grouse, weighing $11 \frac{1}{2}$ oz., was shot in the parish of Weedon on 15th inst. It flew out of some turnips close to a rick of barley, where it had evidently been feeding, its crop being full of the same." This specimen was stuffed and mounted (as I believe) by Mr. Bazeley, who obligingly sent me a photograph of it after the operation.

\section{BLACK GROUSE.}

Tetrao tetrix.

The only occurrence of this species in Northamptonshire which has hitherto come to our knowledge will be found recorded by me in the 'Zoologist' for 1851, vol. ix. p. 3278, in the following words :- " A Grey Hen was observed, in September 1849, in a wheat-stubble near Cranford, the seat of Sir G. Robinson, and was afterwards seen three or four times in that neighbourhood and in Grafton Park, and in May or June 1850, a labourer at Cranford, in clearing out a ditch, disturbed her from a nest containing ten eggs, which were put under a hen, but all proved rotten. I never heard of this bird in this county before, and the nearest place that I am 
aware of in which they are indigenous is Sherwood Forest, in Nottinghamshire." I may add that my informant was my cousin, the late Rev. George Stopford, who was then rector of Warkton, near Kettering, and saw the above-mentioned bird on more than one occasion.

'The present is a very erratic species, and often wanders far from its regular haunts, of which the nearest to the above-mentioned locality is, as I believe, really Charnwood Forest, in Leicestershire.

Abundant in many parts of Scotland, and more or less common in the border counties of England, I find the Black Grouse recorded as a resident species in Nottingham, Salop, Stafford, Norfolk, Wilts, Berks, Hants, Sussex, Surrey, Dorset, Somerset, Devon, and Cornwall, as also in a few counties of Wales, but in none of these localities can it be called very common; it is not indigenous in Ireland, and all of the many attempts made to establish it in various parts of that country have, so far as I know, resulted in failure. The localities especially affected by this species are rough moors bordered by woods, with an abundant supply of water and of rushes. In August and early September I have often come upon broods of Black Game far away from any trees or even bushes of any kind, but never very far from water or the favourite rushes. At this season there is no difficulty in destroying the whole brood, as they run close before the dogs and eventually squat till actually kicked up one by one; it is not, however, by any means so with the old cock-birds, who are at all times exceedingly wary and cunning, and, being in moult during the early part of the shooting-season, are seldom to be met with away from good covert, amongst which they 
run and hide when pursued, and, on being flushed, generally are wise enough to fly back over the heads of the beaters instead of coming forward over those of the "guns"; as the season advances, old and young crowd to glean upon the cleared stubble-fields adjoining the moors, and excellent sport is then to be had, both by stalking and driving.

The food of the Black Grouse varies with the seasons, but, whilst they are to be found, we think that the seeds of the rush form the favourite staple; besides these the common moor-growing berries, corn of all sorts, and the young shoots of birch, alder, and various species of fir all come in for a share of attention according to circumstances, and ants and their eggs are very favourite morsels, as is the case with most of our game birds. As our acquaintance with the habits and customs of the Black Grouse during its breeding times is very limited, we must refer our readers to the many writers who have described the exceedingly curious scenes to be witnessed on the so-called "pairing-grounds" in early spring, and content ourselves by stating that this species is polygamous, that the nest is usually placed under or near some thick low-growing bush, such as the bog-myrtle; the eggs average about eight or nine, very seldom more than ten, in number, and are of a creamy white, freckled with light reddish brown. We have found young Black Game, hatched out under a common barnyard fowl, easy to rear on a mixture of dry and green food, and an occasional course of ants' eggs; they devour earthworms and certain caterpillars very readily, and become exceedingly tame. Many instances are on record of the interbreeding of this species with the Pheasant and with other species 
more nearly allied to it, and varieties of the pure-bred birds often occur. We had the pleasure of examining the skin of a fine adult male procured in Leadenhall Market, in which a great portion of the plumage of the back and wings was barred and marked so as to resemble in no small degree that of a Silver Hamburgh Fowl. 'The Black Grouse is found in suitable localities in many, if not most, parts of Europe and temperate Asia; its occurrence in Spain, however, seems to be open to doubt, though it is found in certain localities on the French side of the Pyrenees. It is perhaps superfluous to add that as we have neither pine-forests, granite-mountains, nor heatherclad moors in our county, our other three British species of Grouse, viz. Capercaillie, Red Grouse, and Ptarmigan, are not therein indigenous, but there is another European species of this family, to wit, the Hazel-Grouse (Bonasic betulina), which is tolerably common in certain parts of Central Europe, and might, as we are convinced, be successfully introduced into our Islands. The experiment is well worthy of a trial, as the bird in question is a beautiful species, excellent for the table, and would not require much, if any, artificial protection ; it belongs, as does the Black Grouse, to what we may call the arboreal division of the Grouse family, in which the toes are not feathered as they are in our Red Grouse and Ptarmigan.

To return to the subject of the present article, the only district in which we have personally met with it, outside the British Islands, is in the Alps of North-western Italy, where it is sparingly found in the pine-forests, and known to the natives as "Fagiano," which word properly applies to the 
Pheasant. The few Black Game which, with great toil, we had the good fortune to bring to bag in these last-mentioned localities in August 1858 had their crops crammed with cranberries and seeds of the rush *.

\section{RED GROUSE.}

Lagopus scoticus.

A fine male bird of this species was shot in November 1892 near Warkworth in Northamptonshire, and was most kindly presented to me, stuffed and mounted, in September of the following year by Mr. F. W. Holland, of Eydon Hall. I leave my readers to form their own conclusions as to the bona fide traveller or "escape" question with regard to this bird, and can only say that its plumage bore no trace whatever of confinement or captivity. The occurrence was originally communicated to me by Mr. O. V. Aplin, whose work, 'The Birds of Oxfordshire,' is probably well known to those interested in British ornithology, and to whom I am greatly indebted for many valuable notes on the birds of our Oxfordshire frontier.

\section{PHEASANT.}

\section{Phasianus colchicus.}

It is not my intention to enter into a detailed account of the habits of this well-known bird, which, in most parts of our country, and especially in those where foxes are preserved, can only exist under artificial conditions and human protection. Our

* Whilst engaged on the present revision of these 'Notes,' March 18, 1895, a fine adult Grey-hen was brought in to me, killed on the afternoon of that day between Wigsthorpe and Clapton. This bird showed no symptoms of privation of liberty, or food. 
county, with its great woods interspersed with arable lands, is well adapted to the requirements of the Pheasant, and, with intelligent gamekeepers and favourable seasons, we can hold our own in comparison with the bags of Pheasants made in similar districts-but not, of course, with those of Norfolk and Suffolk, the whole of those counties being more or less efficiently "preserved" for Pheasants, their soil most favourable for feathered game, and the natural enemies of game easily kept down. Although it is now difficult to find pure-bred specimens of the species whose name stands at the head of this article, on account of the frequent crossings with the Chinese Ring-necked Pheasant (Phasianus torquatus) and other species, we do occasionally meet with birds, especially in the large woodlands of the northern division of Northamptonshire, which, by their small size, the absence of any trace of the white collar, which is so conspicuous in the Chinese bird, and the intense blackness of the plumage of the lower belly, present the characteristics of the true unadulterated species.

At Lilford we have very successfully introduced the Ring-necked species, and still more so the Green Pheasant of Japan (Phasianus versicolor), both of which interbreed freely with our original stock and with each other; the hybrids are most beautiful birds, greatly exceeding their parents in size and weight, and certainly prolific, inter se, for some generations.

Gamekeepers do not much approve of the purebred Chinese birds, as they are much given to roaming far away from their homes, and from their shy habits are not so easily brought to the gun as the others. With regard to another most beautiful 
species, known as Reeves's or the Bar-tailed Pheasant (Phasianus reevesi), though we have found it hardy, easy to rear, and excellent for the table, our opinion is, that as it possesses the roaming instinct in a still higher degree than the Ring-necked species, and is of a very wild and wary nature, it is not a desirable bird, from a sporting point of view, except in very large ranges of woodland, and from what we have heard from a friend who has been in the native haunts of this fine bird in the mountains of Northern China, we are inclined to think that it is more likely to prosper in Scotland and in Wales than in our midlands. The hybrids between this and the Common Pheasant are beautiful birds, but not, so far as we have been able to ascertain, prolific.

The Pheasant, where not preserved in unreasonable numbers, is a good friend to the farmer, from the enormous number of wireworms and other noxious insects which it devours, to say nothing of its liking for the roots of various weeds; but it would be absurd to deny that grain forms its favourite food, and a field of standing beans will, as is well known, draw Pheasants for miles. It is very much the fashion to feed the birds with maize, but, in our opinion, the flesh of Pheasants which have been principally fed upon this corn is very far inferior in flavour to that of those who have found their own living upon what the land may offer them.

The great question of "battue" shooting is not one upon which we have the slightest desire to enter the lists; as sport, in the legitimate sense of the word, we hold this fashion of shooting somewhat low in estimation, though Pheasants flushed at a fair distance, and put over the guns at a good height, are 
by no means so easy to kill as many persons seem to imagine, and it must be remembered that many game-preservers have no other means of giving their friends a day's out-of-door amusement. Nor can it be denied that the rearing and preservation of Pheasants give employment to many, and supply our markets with excellent and wholesome food, besides enabling the owners of preserves to make very welcome presents to friends and neighbours. But the whole question has been so often and so ably argued by more competent pens than ours, that we are quite content to leave it as its stands. 'There appears to be no reason to doubt that the Pheasant was introduced into England by the Romans, and the bird has now become so spread over most parts of Europe that it is almost impossible to say where it is really indigenous. The only country in which we have personally met with it in an unpreserved and perfectly wild state is on the shores of the Adriatic, near Alessio in Albania, where it is, or was, by no means uncommon in the low-lying forest country near the mouth of the river Drin; it is also to be found in considerable numbers near Salonica and in certain other localities in European Turkey. But the best authorities seem to agree that the true home and headquarters of the species are the shores of the Caspian, the valleys of the Caucasus and northern Asia Minor; very closely allied forms, however, are to be met with from the Caspian, through Asia to the shores and islands of China. White and pied varieties of the Pheasant are very much too common in our county, as elsewhere, the most remarkable and least objectionable, to our minds, being that which, for some mysterious reason, 
is known as the Bohemian Pheasant, and in many respects presents indications of a normal race or species.

\section{COMMON OR GREY PARTRIDGE.}

\section{Perdix cinerea.}

This well-known and most worthy bird has been so often and so fully treated of from every point of view that it is difficult for us to write anything that is not already familiar to our readers, but we confess that having been, since our earliest shooting-days, especially devoted to the pursuit of this species, it is almost equally difficult to abstain from dwelling upon a subject which recalls so many pleasant memories and incidents connected with our own county. In an average January, when the turnips are no more, the Partridges of our neighbourhood take to the grasslands and seem to feed principally upon the ends of the tender grasses and such hedge-berries as they can find under and about the great thorn-fences which separate our pasture-fields. In a mild February, and sometimes even earlier, our Partridges pair, though they seldom lay before the third week of April. During March and the early part of April these birds seem to frequent the young corn more than at any other season; but when they begin to lay it would be somewhat hard to name any place in the country that may not be selected as a site for the simple scratching and few leaves and grass-stems which form the nest. In a dry season Partridges certainly prefer our meadow-lands and the rough patches of weed along the ditch-sides, but standing corn, mowing 


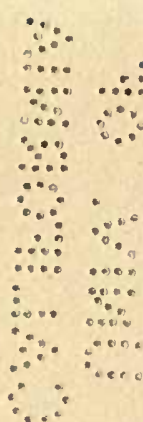


grass, and clover are all likely nesting-places, and in wet scasons many broods are saved by the selection of our old dry fence-banks by the parent birds. The general character of the soil of our part of Northamptonshire is too heavy for a first-rate Partridge country, the essentials for which are a light soil, a combination of arable and uncultivated land, and a good water-supply, but in a good season we can show very fair sport in the neighbourhood of Lilford in September and October, though of course, as in other places, our total bag depends, to a very great extent, upon the amount of covert. In the old days of muzzle-loaders and pointers we used to consider from fifteen to twenty brace of Partridges a fair day's bag for two guns, and often went home happy and contented, after a good hard day's walking, with less than half the latter number of birds, but now-a-days, except in unusually good seasons for grass, we have no work for pointers, as our corn-lands are laid bare of any covert by the mowing-machines; in thin turnip-crops the birds are wilder than anywhere else, and in good thick "root"-crops a quartering dog disturbs more game than he helps to find; besides this the rapid loading of the present sporting guns hardly admits of the perfection of dog-breaking, and an unbroken dog of any kind is the greatest nuisance with which a Partridge-shooter can be cursed. In these circumstances we are forced to adopt the "walking-up" system, and having thereby put our birds into some kind of covert, we divide our forces, and whilst a certain number of the guns walk with the beaters, the remainder go forward, and concealing themselves as best they may behind a fence in the expected line of flight, deal with the birds as they 
"come over" to the best of their ability. In this way we make fair bags of Partridges, and as the old birds lead the coveys, and are therefore the first to suffer, we are strongly of opinion that this method of shooting tends to the increase of the species, as a superfluity of two- or three-year-old birds is certainly "bad for the breed," and in the neighbourhood of Lilford the number of Partridges has increased in a very remarkable manner since we took to "driving," in spite of several most disastrously unfavourable seasons.

Our Partridges have innumerable enemies, of which a wet hatching-time is undoubtedly the worst, but straying and hunting dogs who put the sitting birds off their nests, the mowing-machines which mangle and immolate old, young, and eggs by dozens, rats, foxes, stoats, all the members of the genus Corvus, to whom eggs in any state seem an irresistible temptation, and Sparrow-Hawks, who will clear off a whole brood of young birds in a very few days, to say nothing of idle and thieving lads, all have to be taken into consideration by those who, like ourselves, have been and are more anxious about our breed of Partridges than any other game. It is rather the custom of gamekeepers to put everything down to "them cusséd foxes"; but although a vixen with cubs has an undoubted predilection for Partridge eggs on the point of hatching, we have very good reason to believe that many delinquencies now laid to the charge of this sacred quadruped are really to be attributed to other and more abundant vagabonds. We have omitted the cat, the weasel, the hedgehog, and the snake from the above list of foes to the Partridge, as the first does not, to our knowledge, 
destroy eggs ; the second amply compensates for any harm done to game by the destruction of mice and young rats ; against the third we have never personally been able to prove the charge of egg-stealing, and snakes are not sufficiently common in our neighbourhood to do any appreciable amount of mischief by terrifying the hen bird from her eggs and causing her to forsake them, as is frequently the case in localities in which these reptiles are abundant. We consider from sixteen to nineteen about an average complement of eggs for the present species, and are inclined to look upon the frequent instances of twenty-five or thirty eggs as the layings of two birds in one nest. Before the full complement is laid, the bird will often cover her eggs with a few dry leaves, and we have several times been puzzled by this device in finding a previously discovered nest on a second visit. Many authentic instances are on record in which Partridges have been known to move their eggs from dangerous situations. In an average season, we consider from about the 16th till the end of June as the critical hatching-time. In one instance in which we had special facilities for observation, from the fact of the nest being situated in a flower-bed close to the house at Lilford, one egg in a laying of seventeen was cracked on the morning of June 18th, and on the afternoon of the 21st seventeen young birds had come safely into the world : in this case the male bird was in a constant state of anxiety during the process of hatching, and ran to and fro on the stone balustrade which surrounds the flower-garden, calling loudly at all hours of the day. Both the parent birds will show great courage in attacking dogs, cats, or any winged 
enemies who may approach their tender young, but we have never been personally attacked by a bird of this species, as we have by a pair of Virginian Colins (Ortyx virginianus), who had just hatched near a footpath not far from Lilford. We may here mention that in spite of various attempts to establish this latter species in our county and many other parts of England, as well as in Scotland and Ireland, our efforts have all ended in failure, as the Colins, after doing well and breeding freely in many cases for two or three seasons, eventually disappeared entirely. To return to our Partridge: happy is the covey hatched off in our old pasture-lands, remote from footpaths, with an abundant supply of ants and their eggs at hand, and a disused and broken ant-hillock on which to take its frequent dust-baths; no need to resort to roads for that purpose, or to the corn-lands for food, and safe from all but natural enemies till September. These grass-bred birds seldom voluntarily leave the grasslands except when hatched in the immediate neighbourhood of corn, to which, in such cases, they resort to feed soon after daybreak and again in the evening; but we feel sure that a very considerable number of our Lilford Partridges never touch corn at all. Besides all kinds of grain and many "green stuffs," Partridges are great devourers of insects in all stages of development, and do infinite service to the farmer; in fact this bird is desirable from every point of view: beautiful in shape and plumage, superexcellent as food, affording healthy exercise and inexpensive sport to great numbers of all classes, the Partridge is, in our opinion, the most worthy of protection of any of our British birds, and even its call, though not strictly speaking musical, defies 
imitation, and has a peculiar and indefinable charm to all lovers of the country. To keep up a healthy stock of Partridges an occasional change of blood is absolutely necessary, and we have at Lilford turned out at various times a considerable number of birds imported from Hungary and Bohemia, with very great advantage. As is well known, Partridges are by no means difficult to rear by hand, and thrive well upon a diet of ants' eggs, curds, seeds, and green food, but these hand-fed birds are liable to various maladies from which their wild relations seem to be exempt, and, from their tameness and habit of running and rising all together, never show the same sport as the wild natives.

The season of 1884 was decidedly the best for Partridges in our neighbourhood since 1859, and our total bag on our own shootings was larger by more than 400 birds than in any season of which we have any record *. We cannot say how we shall be borne out by meteorological observation when we state that in our experience good and bad Partridge-seasons occur in cycles ; for instance, with us at Lilford $\mathbf{1 8 5 0}$ was a fairly good season, 1851 a better, and 1852 superlatively excellent; the three following years were all exceedingly bad, till in 1855, to use a common expression, we had no birds at all, and on the 1st of September of that season my brother and myself walked over some of our best farms with good pointers and only saw five birds. In the following two seasons of 1856 and 1857, which were both of them favourable, our Lilford Partridges re-asserted themselves, and in 1859 the county was swarming

* Our subsequent "bags" in 1887 and 1892 by far exceeded that of 1884 . 
with them; then followed a cycle of bad and indifferent seasons, till 1868, a year of extraordinary drought, but many birds, since which period we had a majority of bad seasons till 1878; then a fairly good one, three bad, and three decidedly good. On the light stony soils to the south and south-east of Stamford we have occasionally found Partridges in numbers which would compare favourably with the best districts of Norfolk, and enjoyed the cream of shooting in the muzzle-loading days, but the details of the seasons, as above related, refer to our own Lilford shootings exclusively. We have occasionally enjoyed fair sport at Partridges with the Hawks of our "Old Hawking Club," but our district is by no means a good one for that form of sport, owing to the abundance of thick fences, woods, and plantations.

The Grey Partridge seldom perches, but we once in Lancashire saw five alight upon the roof of a cottage, and one of the gamekeepers at Lilford assured us that in August 1884 he saw some eight or nine of these birds upon the top bar of a field-gate near Achurch. 'The partiality of Partridges for the neighbourhood of roads and well-used footpaths as a nesting-site is well known, and is probably owing to the facilities afforded by such spots for "busking" or dusting themselves. We have heard of an instance in which the clerk of a parish in one of our eastern counties gave notice during a Sunday morning's service that the rector requested his congregation not to use the usual approach to the church on account of a Partridge sitting on her nest close thereunto. The Partridge sits very closely and constantly, but will easily desert her eggs if suddenly 
startled by a dog. These birds do well and thrive for long periods in a well-kept aviary, but instances of their breeding in captivity appear to be very few and far between. Our Partrilge is found more or less abundantly throughout Central and Northern Europe, but is not met with in any of the large islands of the western Mediterranean, and in Spain appears to be confined to the mountain-ranges of the north and north-west; we have met with it in Aragon and in Santander, generally high up on grassy plateaux in the hills. Varieties of the Partridge are not uncommon, though we personally have met with very few of them: we occasionally, on one particular beat near Lilford, meet with birds in which the horseshoe on the breast so characteristic of the species is of a deep bronze colour instead of the usual dark chestnut, and now and then with individuals in which this marking is white. We have never been able to verify the accounts given by various authors of the more or less regular migrations of the Grey Partridge in the south of Europe, but have ascertained, to our own satisfaction, that it does not exist in many localities in which it has been recorded as abundant, amongst others Sicily, Sardinia, and North Africa. In the western portions of European 'Turkey, bordering the Adriatic, this species is curiously local, and many ardent sportsmen of our garrisons of the Ionian Islands, before their unhappy cession to Greece, were in the habit of shooting constantly on the mainland of Epirus and Albania without even meeting with what we fondly call the English Partridge, but the bird is, or was, nevertheless, fairly abundant in certain localities at no great distance from Corfu, and other of these former 
most pleasant quarters of the British soldier. We have heard in our own county and elsewhere of hybrids between the Grey Partridge and the Redlegged Caccubis rufa; but the only one of these supposed hybrids which we ever personally examined proved to be a specimen of the so-called Grey Partridge of India, Francolinus ponticerianus, and we have yet to be convinced that our Partridge ever contracts alliances out of his own kindred.

\section{RED-LEGGED PARTRIDGE.}

Caccabis rufa.

The earliest occurrence of this species in North Northamptonshire with which we are acquainted is that of a specimen killed by the late Rev. George Stopford near Bulwick: we have no exact record of the date, but remember seeing the bird at Bulwick Hall, stuffed and mounted, on the occasion of our first visit to that house, now more than fifty years ago. The first Red-legged Partridges that we ever saw in a wild state in the district of which we are treating in these notes were on a rough fallow in the immediate neighbourhood of Elton, Hunts, about the year 1850. We found that their existence there was well known to Lord Carysfort's gamekeeper, who accompanied us on this occasion, and informed us that he had known of a covey or two on the manor annually for many years before the date above given. About the year 1860 we killed one or two on our own shootings at Lilford, and heard of several occurrences of the species in our neighbourhood; and since that date the "Frenchman," as the bird 
is commonly called, has firmly established himself at all events in the northern division of our county, and at Lilford we and one of our neighbours have at various times added to our own stock by importations, chiefly from the eastern counties. Most of our readers are probably aware that this bird is not an indigenous British species, the main importation, according to Yarrell, having been made about the year 1770 by the Marquis of Hertford and Lord IRendlesham, who turned out a considerable number of Red-legs, hatched from eggs obtained from the continent, on their estates in Suffolk; whence, with several more recent importations into that county, the birds have spread, thriven, and become very numerous in suitable localities throughout Norfolk, Suffolk, Essex, and the adjoining counties. 'The Red-leg is of a running and roaming disposition, and may often be searched for in vain in a locality in which numbers have been found a few days previously. The nesting-habits of this species resemble to a great extent those of the Grey Partridge, but it commences to lay somewhat earlier, and does not seem to object to nesting in thick brushwood, which is not a common practice with the latter bird. The eggs average from twelve to sixteen, and are of a creamy yellow, with rust-coloured spots and freckles. To those who shoot over pcinters the Red-leg is a very objectionable bird, as his first impulse on being alarmed is to run off at full speed, with occasional halts for observation, and if really hard pressed to top the fences generally at a corner of the field, and alighting immediately to set off to cross the next field diagonally on foot. It has been, in our experience, quite an exceptional event to get a fair shot at a bird of this species on 
its rising before us, even from the thickest covert, and it is only by the driving system that a fair proportion of Red-legs are to be brought to bag; they are at all times cunning, and very apt to run for a corner if they have heard shots fired to their proper front, but when once they have decided on their line of flight no amount of shooting will turn them when on the wing, and where one or two have "come over" the great majority in the drive will continue to come. We have often, when standing behind a low fence for a drive, seen the "Frenchmen" making good running straight for us till nearly within shot, when they would pause, squat, and on hearing shots or seeing the head of a gunner above the fence creep off in a crouching manner to right and left. If they are observed to run with their beaks open their "wind" is exhausted, and they will not rise, but run for the nearest covert, and often in such cases take refuge in a covered drain or a rabbit-burrow. The flight of the Red-leg is very much faster than it appears to be, and this bird sometimes comes along on wing with an indescribable look of being wounded, which is somewhat puzzling, as no doubt it is intended to be. We, on one occasion, marked down a Redleg, which had not been shot at, into some thick sedge on the bank of our river near Lilford, and on taking a dog to the spot the bird jumped into the water, swam easily for a few yards, scrambled out again on a bare place, and took wing as if nothing unusual had happened, and on another occasion, in the "Broad" district of Norfolk, we saw two of this species swimming with apparent ease and equanimity on a brimful marsh-ditch.

The Red-legged Partridge frequently perches on 
bushes and trees, especially in wet weather, and may often be seen on stone walls. As a rule these birds thrive best upon light sandy soils, but with us in Northamptonshire they seem to vary their haunts without regard to the character of the ground or the crops growing thereon, only seeming to prefer an old weedy fallow field to any other locality. The flesh of the Red-leg is white and much drier than that of the Grey Partridge, but in our opinion is by no means to be despised. A belief existed in the eastern counties that the "Frenchman" interferes with and drives away the indigenous species, and on this account, in many places, attempts were made to exterminate the foreigners by destroying their eggs and killing the birds at all seasons, but our experience goes to prove that this is a mistake, and in the only actual encounter ever witnessed by us between old males of the two species, the Grey bird had decidedly the best of it. 'The present species belongs to a division of the Partridge family to which naturalists have given the appellation of Caccabis, of which division three other species are found in Europe; these differ but slightly in coloration, habits, or cry, which is a sort of chuckling crow of five or six notes frequently repeated and very sonorous. The present species is the Partridge of Spain, in which country it still abounds in spite of the incessant warfare waged against it by man and numberless four-footed and feathered enemies at all seasons. Many Spaniards of high and low degree are excellent shots and most indefatigable walkers, but the prevailing method of Partridge-shooting is by means of a caged bird, who calls up, or ought to call up, the wild birds of his species to their destruction by the gun of Don 
Fulano, who sits or lies well hidden hard by. These call-birds are kept in small cages, in which they can barely turn round, and in spite of this close imprisonment and the idea, which seems to be well founded, that they die if water is given to them, these captives live in their cages for many years, and a good caller is only to be bought at a very high price, and sometimes hired for the day at a rate that usually far exceeds the value of the birds lured by him to their death. Throughout Morocco, Algeria, Tunis, and, we believe, Tripoli, the genus Caccabis is represented by the Barbary Partridge, C. petrosa, a species which is only met with in Europe in the island of Sardinia and on the Rock of Gibraltar, to which latter locality it has been imported from the opposite coast of Africa. This bird has been admitted by some authors into the British list on the strength of a few occurrences in various parts of England, of which particulars will be found at pp. 121, 122 of the fourth edition of Yarrell's 'British Birds,' with the reasons for its present exclusion from the said list. Another species of this division, C. saxatilis, known as the Greek Partridge, is found in many of the mountainous districts of France, Switzerland, Austria, Italy, European Turkey, the Ionian Islands, and Sicily, in which island it is the only indigenous Partridge, whilst in the Egean archipelago, Cyprus, and Asia Minor a fourth species, C. chukar, is the representative bird. We consider Spain as the headquarters of the present species, C. rufa; it is also found in most parts of France, and locally throughout Northern and Central Italy and the Italian Islands, with the exceptions of Sardinia and Sicily, as above stated. We have pursued and shot 
all four of these species, of which we consider the so-called Greek Partridge the best, and the Barbary infinitely the worst, for the table.

Shooting Red-legged Partridges is, from their habit of running before dogs and the generally very rough nature of their haunts, at all times a somewhat laborious business, but large bags may be made of the Barbary Partridge in North Africa, in many parts of which country it is extremely abundant. 'The best sport we have ever met with at the common Red-legged bird was on the heathy moors of the island of Minorca, which are divided by rough stone walls, through which the Partridge of course cannot run; the covert is also very close and thick and not too high, so that the birds got up at fair distances, and with a few Quails and Rock-Doves gave us very pretty shooting. 'This bird makes a peculiar whirring or ringing sound with the wings on rising, and in Norfolk one learns soon which species to expect before seeing the birds. All the Red-legged Partridges are attracted by unusual sights, and we found that in Tunis the herd-boys kill a good number by putting on a brilliant piece of coloured cloth, or a skin of jackal or fox, over their heads and crawling towards the coveys in a zigzag fashion, often when within range knocking down several with one throw of the heavy knobbed sticks which they almost all carry. Our Red-leg is easily kept in captivity, and becomes very tame, but not to the same extent as its congener, the Greek Partridge above mentioned. We have at several times kept one or more of this last species, which ran about the house, would follow us for long distances, and always come to our call. On the whole we consider that Caccabis rufa is a 
valuable and handsome acquisition to our British game birds, and it is, with the exception of the various species of the Pheasant family, the only artificially introduced bird of any exotic species which has become thoroughly acclimatized and thrives at large in our country. Our climate and soil would not suit the Greek Partridge, and the Barbary bird we can dispense with, but we are convinced that there are many species valuable from a sporting and a gastronomic point of view which might with care and attention become common in our Islands; we would especially recommend the genera Tetrao and Francolinus to the attention of acclimatizers.

\section{COM MON QUA I L.}

Coturnix vulgaris.

This species, which appears, from the accounts of old sportsmen and partly from our own recollection, not to have been uncommon in our county in the first half of the present century, has become decidedly scarce with us now, though few seasons pass in which we do not hear of its occurrence. Morton writes of the Quail as follows:- " Of the Quail, a Bird of Passage- $\mathrm{I}$ have only to note, that it comes into the sandy and warmer soil, (e. gr.) on the Northampton side, and near Rowel, and is to be met with there, at least a Fortnight before it settles in the colder Clayey Part of the County." From the above passage it is evident that the author quoted regarded the Quail as a regular visitor to the county, and we well recollect an old gamekeeper who had lived in the service of my grandfather, my father, and 
myself for some sixty years, and died some thirty years ago, having nearly attained his hundredth year, assuring us that in his youth several broods or bevies of Quails were to be annually met with on various farms belonging to us. In our own shooting experience in the county, we never had the good fortune to meet with a bevy, but now and then used to find one or two of these birds on the manors of Pilton, Wadenhoe, Aldwincle, and Tichmarsh in September, and on several occasions met with what our people would call " a hodd un" in the depth of winter, one of these latter cases occurred in rather a curious manner, as follows :- In the severe frost and snow of January 1855, we were searching for Snipes along a partially open brook, with a strong and high double thorn-fence on the far side from us; a Snipe rose at a short distance and fell dead to our shot into the middle of the said fence. We sent our old retriever to fetch the bird, and after some difficulty in working her way into the fence, we heard her make a rush and cried "Ware Rabbit!" but in a few seconds she came struggling back to us through the thorns with a Quail alive and uninjured in her mouth, and then went in a second time and brought out the Snipe to us quite dead. In July 1870, two Quails' nests were mown out in our meadows near Thorpe, and the eggs brought to us, and Mr. F. Bruce Simson of Broom Hill, Spratton, has very kindly informed me that in the summer of $\mathbf{1 8 8 0}$ he frequently heard the unmistakable call of this species near his house, and shot several in the neighbourhood in the following September. A Quail was shot on September 1st, 1882, in a field of standing beans near Lowick. The Quail loves cultivation, but prefers the ancient style 
of that art, and does not approve of enclosures; this we take to be the reason of the scarcity of the species in many parts of our Islands in which it was formerly abundant, but it is still to be found pretty certainly in summer and early autumn in many parts of the fen country, and till very recently was abundant on a property of ours in South-west Lancashire in districts drained and reclaimed from the bog, or "moss," as it is locally termed, within the memory of living men. In this locality a few Quails always remained throughout the winter, as we have reason to believe is generally the case in those parts of Europe in which the bird breeds, although the great bulk of the species migrate southwards on the approach of winter; this being their habit, it is somewhat difficult to give dates of arrival and departure with any approach to accuracy, particularly in the instance of the Quail, which, in this country at least, is pretty certain to be heard in the spring before it is seen, but we should consider that the principal arrival of Quails takes place in England in the third and fourth weeks of April, and that the majority are gone by the beginning of November. The cry or love-call of the male Quail consists of three shrill notes, which may be rendered as "whut we whee," with a strong sibilant accent on the first syllable: "wet my lips" is a common rendering of the sound into words, and perhaps as near the original as our language permits. The Quail, in common with many terrestrial birds, is a powerful ventriloquist, and we have often heard a caged bird of this species calling within a few feet of us, and conveying the impression of a distance of many yards. The note of the female consists of two low short notes repeated three or four times in 
succession. The nest is a very simple affair, a mere scratching of the ground, with a few dry bents as lining, and in our experience is generally met with in grass, lucerne, or common clover. We never found more than ten eggs in a nest, but more are often laid. Of the date of hatching in this country we can say nothing, but in Greece, Turkey, and Spain have met with young Quails perfectly fullfeathered and fit to shoot by the middle of August, when they are generally covered with fat, and most delicious as food. This species is the only representative of the genus Coturnix that is found in Europe, and its range extends from Scandinavia to the Cape of Good Hope, and from the Azores to Japan. We have met with the Quail in every part of Europe and North Africa that we have visited, but nowhere in such abundance as in the Ionian Islands during the vernal migration : their numbers, however, at this season vary greatly, and though in the latter end of April 1857 Corfu and the neighbouring islands of Paxo, Antipaxo, and Fano were literally swarming with Quails for three or four days, at the corresponding season of the year 1858 it was difficult to bag more than ten or fifteen couples in the most favoured localities. This Spring-Quail shooting on the western side of Corfu is rather hard work, as the birds are principally found in the currant-vines on very steep hill-sides; and we have shot many a Quail which fell from 100 to 150 feet, and had to be retrieved by scrambling down through the interlaced branches of the terraced vines aforesaid under a warm sun. In our opinion the birds at this season are hardly worth the trouble they cost in the locality just mentioned, but the lovely scenery of Corfu and 
the variety of birds to be met with on their vernal migration to some extent repay a sportsman of an ornithological turn of mind. On the mainland of Epirus in August and September, fair Quail shooting may often be had in the cultivated lands, and in the latter month the sport may be varied with a few Great and Common Snipes, an odd Duck or two, and the walking, though generally more or less "soft," is comparatively easy. In the cultivated plains around and below Seville vast numbers of Quails are bred, and some are to be found at all times of the year, though their numbers are much thinned in the pairing-season by a clever method of calling up the birds into a net. This bird is a great favourite in Spain, and in every village street Quails are to be found in cages, petted and made much of on account of their song. Incredible numbers of this species are netted during the vernal migration on many parts of the Mediterranean shores, especially in Egypt and the southern provinces of Italy. We remember seeing a steamer at Messina, in the month of May 1874 , one of whose officers assured us that she had six thousand pairs of Quails alive on board, all destined for the London market. The unhappy birds are carried in low flat cages or boxes wired only in front, and it is surprising what a very small percentage of them die on the voyage unless "a sea" happens to break over them; they thrive well on millet and soon become fat; but in our opinion this traffic should be prohibited, as the unfortunate birds are caught on their way to their breeding-quarters, and some of them, at all events, would afford sport at a legitimate season when naturally fit for the table. Quails will thrive for many years in confinement if 
kept properly clean, and become very tame, but are always very pugnacious among themselves at the pairing-season. Several of this species have at various times come aboard of our yacht in the Mediterranean, and one, which was found on deck off the coast of Cyprus, in April 1875, lived peacefully for some weeks with a Turtle-Dove which was caught in the same manner, but killed two or three of its own species; this individual lived in good health and condition for several years in a small cage. The flight of the Quail is straight and fast. They are very easy to shoot in the open, and seldom fly to any great distance, but are difficult to flush a second time, and run and squat in a manner which often baffles the best of pointers. The best dogs for Quailshooting are, in our opinion, small close-questing spaniels. Large numbers of Quails are taken in the Danubian provinces with Sparrow-Hawks, which are caught and trained for this especial purpose, and restored to liberty after the passage of their "quarry."

\section{LAND-RAIL.}

Crex pratensis.

At p. 425 of Morton's 'Natural History' of our county we find the following words:- " the Railthat has its name, as some suppose, from Royale, because it is a Royal or a Princely Dish, we pretty often meet with, particularly in the Fields about Thengford, Northampton, Halston, and Rowel; which yet is so rare that 'Turner saith, he never saw nor heard of it, but in Northumberland." On this text we may say that whatever may have been the 
case in the days of our historian, the Land-Rail, or Corn-Crake, is now a very common summer visitor to our county, and though not often to be seen without special looking for and hunting up, may be heard at almost all hours of the day and night, all along the valley of the Nen, from early May till the end of June. We certainly never heard the cry of this bird in Northamptonshire before April 20th, and very seldom so early as that date, and consider that the usual time for its arrival with us is during the first week of May; but it is more than probable that, as in the case of many other migratory birds, the Rails may be in the country for some days without making their presence known. The favourite food of the Land-Rail consists of small snails, and whereever these are to be met with one may expect to meet with, or at all events to hear, this Crake. In a dry May, when our low-lying meadows are comparatively bare of grass, our birds take to the wet ditches and the covert of aquatic plants on the banks of the river and brooks; but as soon as the meadow-grass, young corn, or clover affords good hiding the LandRails take to the open fields, our experience being that they are rather inclined to avoid the neighbourhood of fences and bushes, unless driven thereunto by pursuit or want of other covert.

Though this bird is, as we have said, exceedingly common in our district in the early summer, very few come to hand in the shooting season; this of course is partly to be accounted for by the number of eggs destroyed in mowing with machines, and by the difficulty in making the Land-Rail take wing from the thick seed-clover or standing barley in which it is generally to be found in September. 
But, admitting these facts, it is remarkable that although with good dogs there would be little difficulty in shooting from 12 to 20 Land-Rails in our meadows in a few hours in early May, it is very seldom that our total bag of these birds during the shooting season has reached to the former of these figures. We now and then meet with a Land-Rail or two in October, rarely in November, these lingerers being generally found in common turnips, and we know of more than one instance in this neighbourhood of the occurrence of this species in December and January, but as a rule we consider that our Land-Rails are gone by the end of September. The nest of this bird consists of a few dry grasses, and with us is generally met with in the meadows in the valley of the Nen. The complement of eggs varies from eight to ten; these are of a creamy white, blotched and spotted with grey and rust-colour, and are seldom hatched before the middle of July. The young birds on leaving the shell are covered with intensely black down; we have on several occasions met with Land-Rails unable to fly in the second and third weeks of September.

Although this species is reported to inhabit most parts of Central Europe during the summer, and is of more or less frequent occurrence during migration in the southern regions of our continent, we never met with it in what can be fairly called abundance during the legitimate shooting season, except in certain localities in Ireland; the valley of the Shannon is especially famous for the great number of Land-Rails that frequent it. An old friend of ours, who was quartered with his regiment many years ago at Athlone, told us that having been induced, by reports 
of the abundance of Snipe, to tramp the country in the neighbourhood of that town for a long day in January, without finding more than two or three of those birds, he used very strong language to his informant, who had accompanied him, and said, "I don't believe there are a dozen Snipes in the county." "'Deed then, Captain," replied the native, "the Snipes is not many, but yer honor should be here in the month of May." "What do you mean ? who the $d-1$ would shoot at Snipes in May?" "Och, thin, it isn't Snipes at all, but the Corn-Crakes does be barking like dogs all around the barracks." For once in a way subsequent experience proved this statement to be literally true.

In captivity the Land-Rail is easily kept in good health if allowed plenty of room and supplied with a variety of suitable food; these birds soon become exceedingly tame, are very pugnacious, and very dangerous companions to any other birds that they can master. We have more than once seen a LandRail feign death in the manner related of the Wryneck in our article on that species. The well-known cry which has gained for this bird the common name of Corn-Crake is generally supposed to emanate from the male bird only, but of the accuracy of this supposition we entertain very considerable doubt. No one who has only seen these birds flushed from thick covert, with legs hanging, and apparently laboured flight for perhaps a hundred yards, would believe in their power of rapid, sustained, and lofty progress through the air, but it has happened to us on one occasion to see a Land-Rail passing high overhead, and apparently travelling for pleasure, and, again, we remember one of these birds that 
having been flushed twice, fairly took the air and went quite out of our sight at a great height from the ground, and with a speed quite equal to that of the ordinary flight of a Wild Duck. In 1886 the Land-Rails in our neighbourhood carried on their craking note till the middle of August, and were found in somewhat unusual numbers till the second week of October; these variations from their usual habits were doubtlessly caused by the destruction of their first nests by floods and cold weather in May and the early part of June. The form of the LandRail is most admirably adapted for rapid running through thick grass and corn, and the ease and speed with which it will glide and double through the thickest clover when chased by a dog, must be seen to be believed. In Spain and other countries of Southern Europe one or two of the present species are supposed to accompany each great flight of Quails on their vernal migration, and to act as pilots to these little feathered excursionists; in fact the Spaniards call the Land-Rail "Guide of the Quails," whilst in France "King of Quails" is the name by which our bird is generally known. Whether this latter title was originally applied as a tribute to the excellence of the flesh, the superior size, or the supposed guiding capabilities of the Land-Rail we are unable to say; be this as it may, a fat Land-Rail in September is, in our humble opinion, one of the most delicious of birds. 


\section{SPOTTED CRAKE.}

\section{Crex porzana.}

This bird is a not very uncommon visitor to the meadows of the Nen, but we have no authentic information as to any discovery of its breeding in our county; the occurrences of the species in the neighbourhood of Lilford that have come to our knowledge have been in the months of August, September, and October, when the birds were, in all probability, on their southward migration. The Spotted Crake, or Rail, is a vernal migrant to those parts of our country in which it breeds, and generally leaves them towards the end of October. We have met with a good many of these birds in the district of the Broads in East Norfolk in the month of March, and on one occasion found a considerable number in Whittlesea Wash, when we were in pursuit of Snipes there in October. Before the draining of Whittlesea Mere, this species and many others, " whose place now knows them no more," bred in abundance on the borders of the lake. Mr. John Hancock, of Newcastle-on-Tyne, kindly informed me that in an egg-collecting expedition to Whittlesea and Yaxley in 1843, he and his companion met with the nests and eggs of the present species on the reedgrown shores of the mere, in numbers almost equal to those of the Water-Rail (Rallus aquaticus),- which was then a very common resident in the locality. Most of the occurrences of the Spotted Crake that have come to our knowledge in the neighbourhood of Lilford have been in very wet years ; in August and September of 1880 , when all our meadow-grass, cut 


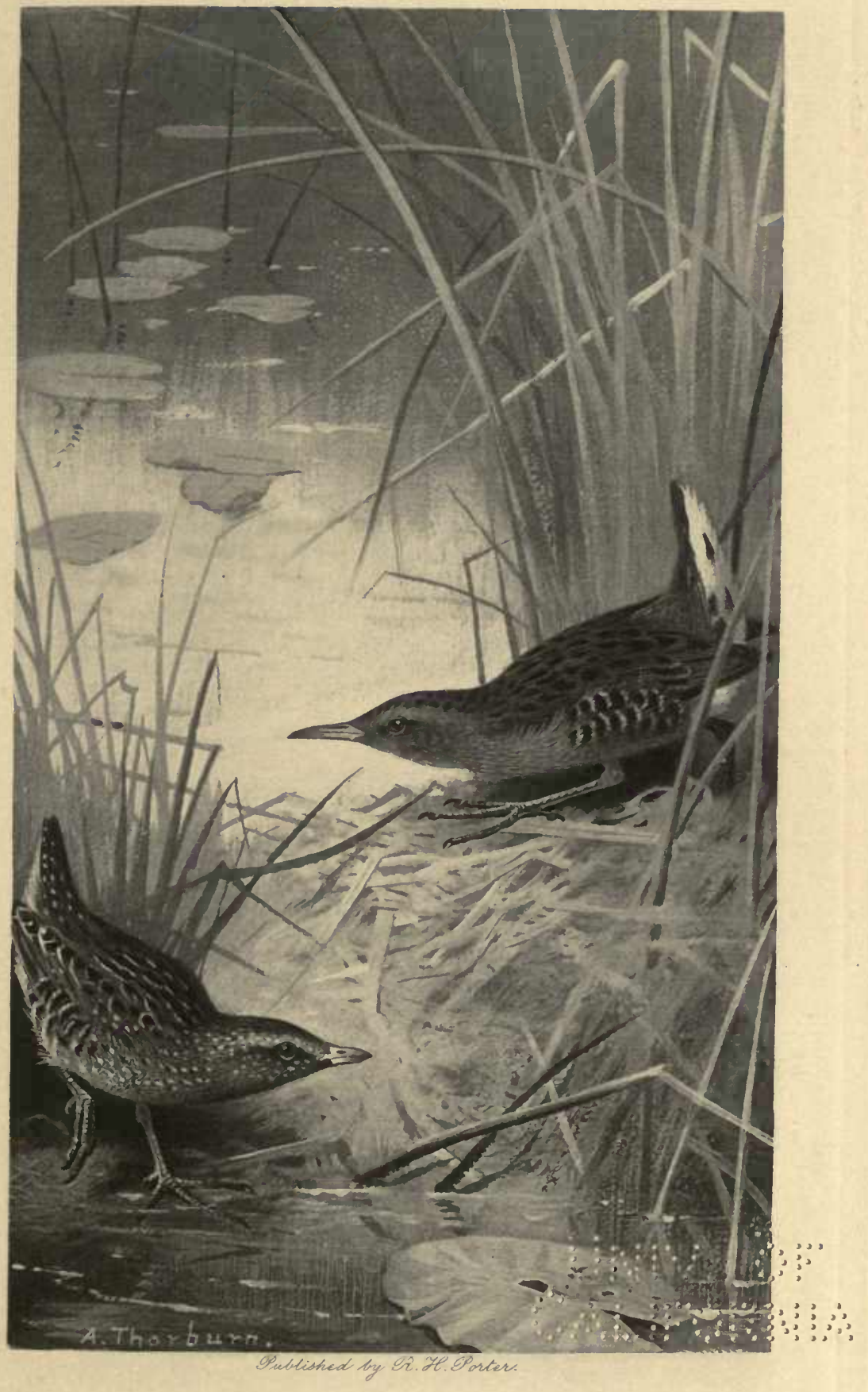

Srotted Erake and Water- Rail 

and uncut, was rotting on the ground, four of these birds were shot and several more seen. My personal acquaintance with this bird in the early spring, late summer, and autumn in this country, Spain, Epirus, Sicily, and Cyprus, leads me to consider it a much less reed-and bush-haunting species than the WaterRail, though the nest appears to be often, if not generally, situated amongst reeds. I have almost always found the Crake in open rush-grown meadows, or on sedgy margins of streams and ditches, also in great abundance in October on the muddy shores of the Bay of Butrinto, in Epirus, amongst a lowgrowing gummy plant (the name of which I have forgotten) that is very common in such localities in Mediterranean countries.

I have never myself met with a nest of this Crake, probably for want of determined search; it is described as being large for the size of the bird, and composed of the leaves of water-plants, reed, sedge, \&c. The number of eggs appears to average from eight to ten; they vary a good deal in ground-colour and markings, but may be roughly described as of a pale buff, with irregular blotches and specks of various shades of reddish brown, and what may be called "stains" of dark grey. 'These Crakes are very noisy and have a variety of cries, some of which bear a slight resemblance to those of the Waterhen, though of course not so powerful ; their common spring call always reminded me of the single note of the Pied Woodpecker, but is not so harsh. In the great marshes near Catania, I often noticed that a gunshot would set off these birds and several allied species screaming, twittering, and whistling for some minutes, in the same way that a distant clap of thunder, the 
firing of heavy ordnance, or an explosion of any kind will set all the cock Pheasants within hearing crowing their loudest.

In general habits of skulking and concealment this Crake much resembles the Land-Rail, but it is more strictly aquatic, swimming and even diving, when pressed by a dog, with great ease and rapidity; its flight also is quicker than that of the Corn-Crake, and it takes wing more readily than that bird. I am not aware of the occurrence of either of the two smaller European Crakes - Baillon's Crake, Crex bailloni, or the Little Crake, Crex pusilla-in our county or its immediate neighbourhood, though it is more than probable that the former of these two species may have occurred frequently in the Whittlesea fen country, as its nest has been found in Cambridgeshire and in Norfolk, and the bird is common in some parts of the Netherlands and Northern France; I have met with it in great abundance in Southern Spain as also in Sicily and Cyprus. In plumage and habits it much resembles the Spotted Crake, but is very much smaller than that bird. The Little Crake is a bird with which I have very little personal acquaintance, but it has been obtained pretty often in Norfolk and other parts of our Islands. It appears to be the most strictly aquatic of the European Crakes. 


\section{W A TER - R A I L.}

Rallus aquaticus.

Although we never found a nest of this bird in Northamptonshire, I have good reason to believe that it has occasionally bred in the neighbourhood of Lilford, as I have more than once met with young Water-Rails about the river and brooks in July and August, when fishing, or searching for young Wild Ducks or an early Snipe. In the autumn and winter this Rail is by no means uncommon, though its numbers vary greatly in our district in different years, and no doubt many altogether escape observation from their strong instincts of concealment and the great difficulty with which they are forced to fly. Our acquaintance with the Water-Rail is pretty considerable, as we have met with it in almost every country and county that we have visited for shooting in autumn, winter, and early spring. Its favourite haunts are dense jungles of reed or, failing these, the banks of sluggish streams, ponds, and ditches overgrown with sedge, and thorn-bushes, amongst the latter we have often found the birds perched at a considerable height from the ground: indeed the Water-Rail is a good climber, and I well remember shooting a good many of these birds in the great floods of the early months of 1853 on Otmoor in Oxfordshire, by forcing them to fly from their perches in the high thorn fences, whilst our dogs were hunting assiduously but fruitlessly along the brimming ditches below. On one occasion, near Lilford, I happened to notice a Water-Rail "keeping small" in a tall thorn fence that I was beating for. what it might produce, with a 
companion on the other side, and a trusty retriever questing along the bottom; I called to my friend to look out, and threw a stick at the bird, who did not budge, and, finding that it would not move in spite of several well-aimed missiles from both sides, I retired some paces and shot it as it sat. On picking it up we found that the poor bird had the best of reasons for not taking flight, as it entirely lacked any vestige or rudiment of wing on the right side, although otherwise in excellent feather and condition. Curiously enough, the retriever above mentioned emerged from a dense reed-bed in Turkey, some years after the occurrence just mentioned, bringing me a Water-Rail alive and unwounded, but having nothing more on one side, where the wing ought to have been, than a slight bony protuberance covered with feathers; in the latter case it is, of course, probable that the wing had been lost by accident, but in the former I feel convinced that no wing had ever existed.

In habits this bird much resembles the Crakes and Waterhens, but its creeping and glicling proclivities are even more strongly developed than in those species, and may almost be described as reptilian; the Rail, however, can sustain a long and fairly rapid flight, as is proved by several captures on board of vessels at some hundreds of miles from land, as quoted in the fourth edition of Yarrell and elsewhere. The food of the present species appears to consist chiefly of worms and small snails; in captivity the Water-Rail thrives well upon chopped liver, becomes impudently tame in a very short time, and is always ready to fight any bird, dog, cat, and probably rat, as long as it can keep its breath and legs. 
The Water-Rail is an early breeder; we have known instances of the finding of its nest containing full complements of eggs (from six to nine) in the third and fourth weeks of March; the nest is a small sample of that of the Waterhen, composed of dry leaves of sedge and reeds, but always well concealed in thick reed-beds or amongst the tussocks of coarse sedge and rushes that abound in many parts of our marsh-lands. The eggs have a general resemblance to those of the Land-Rail, but are usually less spotted, smaller, of course, and more rounded than those of that bird. About dusk these Rails become very noisy, and have a considerable variety of more or less discordant notes-a twittering "skirl " and an abrupt sharp single "twit" being the most noticeable amongst them. From the nature of this bird and its favourite haunts I have very rarely had an opportunity of observing its actions when not alarmed, but its gait at such times resembles that of the Waterhen, with the same jerking of the tail and a frequently repeated low chuckling note. It takes readily to the water, and swims easily and gracefully in search of food.

\section{WATERHEN.}

\section{Gallinula chloropus.}

This bird, more commonly known as the Moorhen, is so abundant in all suitable localities in our Islands, and its manners and customs are so easily to be observed, that I feel that a very short notice will be amply sufficient. The Waterhen may be said to swarm in those portions of the Nen valley in which it is not persecuted by man, and there is hardly a 
pond that I know of in our county, whose banks or surface afford any covert, that is not frequented by one pair or more of these birds as long as their waters remain unfrozen. In sharp frosts we very often find Waterhens in our woods and plantations, no doubt attracted thither by the corn laid for the Pheasants. We have always protected the Waterhens in the neighbourhood of Lilford; but to give some idea of their abundance with us, I may mention that a ruthless neighbour of ours, having met with no Snipes or Wild Ducks in a long walk during a severe frost some few years ago, turned his attention to these unfortunate birds, and shot upwards of one hundred of them in a very short time.

I consider the flesh of the breast of this bird remarkably good food, and have seldom found anyone to disagree with me in this view, but should never think of shooting a Moorhen for the table if I could meet with more legitimate prey in the shape of Snipes or Wildfowl properly so called. These birds become very tame when unmolested, and are a very great ornament to our waters, but we cannot acquit them of the charge of a very pugnacious and destructive tendency amongst their own and other species of birds, and they are most certainly bad neighbours for young Pheasants and Partridges, as they not only consume a good deal of the food intended for game birds, but will now and then capture and devour the birds themselves. In our rambles about our meadows in pursuit of Snipes, we used very frequently to find the fresh remains of Waterhens, the greater part of which had been devoured, as we then thought, by some bird of prey; but though the Sparrow-Hawk is rather too common with us, his numbers are hardly 
sufficient to account for the very frequent and generally quite recently-killed Waterhens that were so constantly met with. The Peregrine Falcon almost always takes its quarry in the air, cats avoid wet places as a rule, and the Waterhens are well able to avoid the attacks of the murderous Grey and Black Crows, so that for some time we were puzzled as to the real nature of the culprits, till at length we found the fresh tracks of a fox in the snow all about one of the bodies in question, and since that time have almost always discovered them or other unmistakable proofs of the recent presence of one of the sacred quadrupeds on such occasions. The Waterhen has another great enemy in the shape of the otter, whose numbers have of late years considerably increased in our neighbourhood, and the omnivorous pike no doubt takes his share of such easy prey; but as our birds usually nest twice, and often three times, in the season, there is little. fear of the species becoming extinct in the Nen valley*.

The nests and eggs of this bird are so well known, and the latter so much sought after for their excellence, that I feel that any description of them would be superfluous. With us, about Lilford, the Waterhen often builds in the thorn-bushes by the riverside at a considerable height above the land or water, and in the summer months we often see birds of this species of all ages drop into the water from overhanging boughs. We have on several occasions

* Since the above paragraph first appeared in print, I have proof positive that, with regard to this species, tho Peregrine very frequently makes exceptions to its usual habit above mentioned, and picks up Waterhens either from or elose to the ground. 
clearly observed young Waterhens busily assisting the old birds in the construction of a second or third nest, or a platform of "bolder" rushes, which these fowl apparently use simply as a resting-, or perhaps roosting-, station. Passing Wigeon and Teal, Pochards, and Goldeneyes seem to be often induced to alight on waters unknown to them by the sight of Waterhens, but the latter never allow a stranger to remain long in their close neighbourhood without attacking and, if possible, driving it off.

\section{PURPLE GALLINULE.}

Porphyrio ccruleus.

In the month of June 1870 a very fine specimen of this handsome species, that had been caught on the London and North-western Railway near Wellingborough by the bearer on the previous day, was brought alive to Lilford, and lived for seven or eight years in my aviary. Several other instances of the occurrence of this bird and its close congener the Green-backed Gallinule (Porphyrio smaragdonotus) have been recorded from various parts of Great Britain; but modern writers on ornithology seem inclined to deny these a place amongst British birds, on the ground of the probability of their escape from captivity. I will, as shortly as possible, give my reasons for taking a different view, at least so far as the present species is concerned. I am, of course, prepared to admit the possibility, even the probability, of escape in some instances, but my five-andthirty years' experience as a purchaser of living birds has proved to me that the Purple Gallinule, though 
locally common enough in certain parts of N.W. Africa and S. Europe, very rarely comes into the hands of our English dealers in live birds; on the other hand, the following closely allied species, viz. P. melanotus from Australia, P. calvus and P. poliocephalus from India and the Persian Gulf, Hydrornia alleni and P. madagascariensis from East and West Africa, and $P$. smaragdonotus, above mentioned, from Egypt, are frequently offered to me for sale from London, Liverpool, and Antwerp. The present species was formerly common in Southern and Eastern Spain, and is by no means extinct in that country or in Algeria, is not rare in the Island of Sardinia, and very abundant in parts of Sicily; whilst I believe that I am correct in stating that none of the other species above mentioned have been known to breed in a wild state in any part of Europe. From the comparative proximity of its haunts, therefore, the occurrence of this Purple Gallinule in our Islands, of its own free will, is at least more probable than that of any of its congeners; it is of a roving disposition, and a good traveller in the air, on land, and on the water. I have not at hand the references as to the number of well-authenticated occurrences of this bird and the Green-backed Gallinule in our Islands; but both species have been recorded several times; and although I will not pretend to believe that some of the former, and probably all of the latter, were not "escapes" from captivity, I must confess that I can see no valid reason for excluding the Purple Gallinule from the British list, at all events whilst the Flamingo and many others are admitted to rank therein.

The present species scarcely differs in habits and 
food from our common Waterhen, but is perhaps more strictly an inhabitant of swampy reed-jungle, and somewhat less terrestrial than that bird; its nests present no difference in materials and structure, and its eggs only differ in size from those of the Waterhen. The boatmen who steered my punt through the reeds of the great marshes of Eastern Sicily and the lagoons of Sardinia told me that these Gallinules destroy great numbers of the eggs and young of all sorts of Wildfowl-a statement that I can very well believe, as I found that those that I have kept in confinement at Lilford would always attack, kill, and devour any bird that they could master, and on one occasion made an onslaught upon a Laughing Kingfisher in our aviary ; in this instance, however, they met their match, and, as far as I can ascertain, never repeated the attack. The beak of this bird is a most formidable weapon, and its strong legs and long toes enable it not only to climb with great ease "hand over hand" fashion, up the reedstems, but also to clutch and hold fast any living victim whilst they put an end to its struggles with their beaks; my birds at Lilford generally fed in this way, on morsels of bread, meat, mice, snails, \&c. The usual cry of the Purple Gallinule is a very harsh and resonant trumpeting note, and at nightfall in Sicily they make a sometimes almost deafening clamour. In captivity this bird becomes very tame; my Gallinules nested more than once in the aviary and laid several eggs, but would never sit steadily, so that no young birds were hatched. The plumage is splendid in the sunlight, and were it not for their pugnacity these birds would be a fine ornament to our ponds. 
130. С $00 \mathrm{~T}$.

Fulica atra.

This bird is more or less common and resident on most of the larger ponds or lakes in Northamptonshire with which I have any acquaintance, especially at Deene Park, where I have occasionally seen at least a hundred Coots on the banks of the lake as I passed along the road that skirts the park fence. On our river near Lilford a few Coots generally appear in autumn, and occasionally a pair or two have remained and bred. Being anxious to establish and encourage them, I many years ago procured some fresh eggs of this species from Norfolk, and put them into the nests of Waterhens; the experiment was attended with perfect success, and for several subsequent years we always had two or three pairs of Coots haunting and breeding within sight of the house at Lilford; but they gradually disappeared, and till 1886 I heard of none about home in the breeding-season for a long time past, and could not discover that any of the few that made their appearance in that year nested in our neighbourhood-in fact I much fear that such conspicuous objects as the Coot and its nest could hardly escape the disastrous attentions of some of the occupants of the vast number of pleasure boats with which our district has of late years become infested.

The Bald Coot, as this bird is often called, on account of its bare white frontal shield, loves open sheets of water, surrounded with reeds, and is not often to be met with on the small ponds and streams such as the Waterhen frequents. Its food appears 
to consist chiefly of water-weeds and aquatic Invertebrata, which it obtains to a great extent by diving; but when pressed by frosts these birds take readily to common grasses, corn, and berries, and no doubt eke out their bill of fare with slugs, worms, and such small fishes as they can catch. I personally never found anything inside a Coot but vegetable matter and fragments of freshwater shells. Though the Coot soon becomes very tame on waters where it is unmolested and accustomed to the sight of human beings, it is by nature an exceedingly wary bird, from which circumstance all wildfowl like its company, and we have been repeatedly baulked in our attempts to get within shot of various species of Ducks by the vigilance of these sooty sentinels. 'The Coot, though heavy in appearance, is an exceedingly active bird, swims buoyantly and fast, and in the length and rapidity of its dives almost equals the Grebes; and although on rising from the water it scratches the surface with its toes, leaving a long "wake," is capable of strong and protracted flight; indeed, some authors state that Coots frequently indulge in nocturnal aerial evolutions over and around their haunts. Be this as it may, I have often heard the loud and peculiar whistle of this species overhead after dark. On dry land Coots are good walkers and runners, and progress over soft mud with the greatest ease; they also can and often do climb thick bushes, and sometimes roost therein at a considerable height from the ground. The nest is a large mass of broken reeds and other water-plants, generally situated near the fringe of a thick reed-bed or amidst a dense growth of flags and rushes, and when its foundations actually rest upon the water, is 


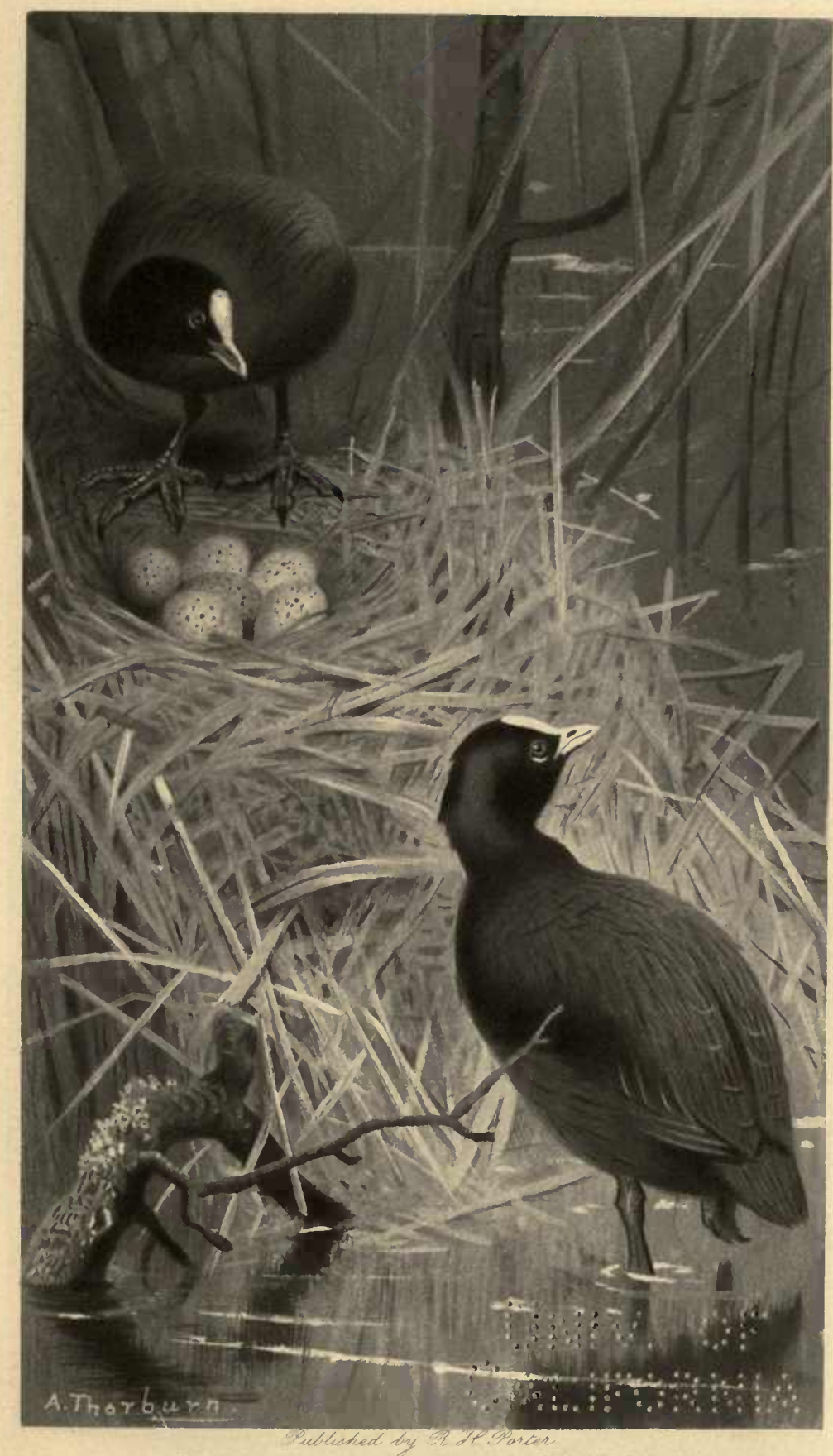

$$
\text { Goots at their mest. }
$$


4 $\therefore$ at a d a 
generally "moored" to the surrounding plants so as to rise and fall with the element. The eggs are generally from eight to ten in number, of a light drab ground-colour, speckled with small very dark brown or black spots or dots; they are, in my opinion, quite as excellent for the table as those of the Peewit.

In severe frosts the Coots crowd into tidal estuaries, and feed to a great extent upon the sea-grass. We have met with this species in all parts of Europe and N. Africa that we have visited. On the brackish lagoons of Eastern Spain, Sardinia, and Corsica, and the great salt-lakes of Provence I have seen many thousands of Coots in the winter; on these latter waters regularly organized Coot-battues are carried out, the days being fixed by the Prefect of Marseille, and printed notices posted up about that town and the neighbouring villages: a flotilla of boats, with one or two gunners in each, starts in a crescentformation up wind upon the birds; the shores are lined with gunners and sometimes hundreds of spectators: the Coots swim off at their best pace, some of them occasionally diving or flying for short distances, till they feel themselves "cornered" by the advancing boats and their enemies on shore. At last the birds begin to take the air in force, and after fighting against the wind for awhile, turn and come back again over the boats, when a fierce fire begins, and continues till the last Coot has passed over or been lilled. After gathering the slain and the cripples, the boats go about and repeat the same tactics down wind. Enormous numbers of Coots, a few Grebes, and occasionally a few Ducks of various species are killed in these battues, and from the 
intense excitement and rivalry of the shooters fatal accidents to human beings are by no means infrequent. I have taken part in a few of these battues on a comparatively small scale in Corsica, and found that the killing of Coots, "rocketting" down wind, from a boat is, to say the least of it, quite as much a trial of skill as the modern system of Pheasant-shooting.

The Church of Rome holds that this fowl is fish, and permits Coots to be eaten on fast-days and during Lent, so that in the countries that border the western Mediterranean these birds will always fetch at least the cost of a charge of powder and shot. The most I can say of the flesh of these birds is that it is eatable when nothing better is to be had; but many people esteem it highly when properly prepared for table, and the general opinion of our yacht's crew on the Corsican coast was that a Coot pie was better than a similar confection of Rock-Doves; we, however, share the taste of an old Suffolk gamekeeper of whom we have been told, who on being asked if he liked Coots for eating, replied, "I can"t say that I fare to be heully wrapped up in 'em."

Coots on the open water defend themselves from the attacks of birds of prey by gathering into a compact mass and, when their assailant makes his stoop, throwing up a sheet of water with their feet. On one occasion in Epirus we saw a White-tailed Eagle so drenched by this device that he had considerable difficulty in reaching a tree at about a hundred yards' distance. 


\section{GREAT BUSTARD.}

Otis tarda.

The only record of the occurrence of this fine species in our county that I have hitherto been able to discover is at p. 425 of Morton's 'Natural History of Northamptonshire,' in the following words:"The Bustard, Otis seu Tarda avis, another bird of the poultry kind, is so uncommon with us that I never heard of more than two of them here, one of which was shot by Captain Saunders in Moulton Ficld." 'The work just quoted was published in 1712, at which time the Great Bustard was by no means uncommon and well known in various districts of England, but from the above extract it would appear that our county did not suit the habits of this bird of the open plains and downs. Norfolk, Suffolk, Essex, Cambridgeshire, the wolds of Yorkshire and Lincoln, and the downs of Hampshire, Wilts, and Sussex appear to have been the favourite haunts of this species in England, and in the 16th century it is recorded as not very common, but occasionally breeding in the south of Scotland. For full details and particulars of the former haunts and habits of the Great Bustard in our country, I must refer my readers to the 4th edition of Yarrell, vol. iii., and to Mr. Stevenson's superexcellent 'Birds of Norfolk.' This species is now, alas! only an occasional and by no means a common straggler to Great Britain, and so far as I know, with one most praiseworthy exception, the few that have appeared of late years have been remorselessly pursued and, in most instances, "done to death." In the volume of 
Yarrell above mentioned will be found a detailed catalogue of the occurrences of the Bustard in England, and one in Orkney, up to the winter of 1879-80. The principal breeding-haunts of the species within the geographical limits of Europe at the present day appear to be the steppes of Southern Russia, Hungary, the lower Danubian provinces, the flat corn-growing lands of certain parts of Eastern Germany, and last, not least, the plains of Central and Southern Spain. My own acquaintance with the Bustard in a wild state is exclusively confined to the last-named country, and as I consider that particulars concerning a bird that is now virtually "a thing of the past" in this country must possess a certain interest to ornithologists, I will detail some of my experiences on the subject.

In Spain the Great Bustard cannot be looked upon as a migrant in the sense of regular periodical arrival and departure from the country, but the birds that have passed the summer and bred on the high plateaux of the central provinces are often forced by stress of weather and consequent scarcity of food to cross the Sierra Morena, to join their brethren in the sunny plains of Andalucia. I have never been in Southern Spain in "dead" winter, but can vouch for the fact that Bustards are to be found within sight of the Giralda of Seville from the beginning of February till September, and have good grounds for my belief that they are never wanting in that locality. At the first date above mentioned flocks of these birds, varying in number from eight or ten to sixty or more, are to be seen on all the pasture and corn lands of the district above mentioned, especially on the proper right of the Guadalquivir a few miles 
above Seville, in the neighbourhood of Algaba and Alcalá del Rio, a country of rolling down-land, for the most part under cultivation.

My experience differs from that of Mr. C. A. Nicholson, as quoted by Yarrell, as he states that the female birds do not arrive in the district in question till the beginning of April, whilst we found flocks of old and young of both sexes all together in February and March; we noticed, however, that the old males, easily distinguished by their bulk and comparatively slow flight, would occasionally separate themselves from the main body, on being flushed for the second or third time, and take off in a different direction. The Great Bustard is a promiscuous feeder, and at different seasons varies his dietary: frogs, mice, snails, earthworms, lizards, beetles, locusts, grasshoppers, and slugs are his animal food, and green corn, especially barley, clover, the leaves of mallow, chick-peas, a little low-growing plant with a dark crimson flower, and vetches, are, so far as I know, the most favoured vegetables in the bill of fare of these birds.

Opinion seems to be divided as to whether the Bustard is polygamous or not. I entertain no doubt whatever on the subject, and am convinced on the correctness of the affirmative view on this point. In favour of this conviction I may state that in Spain the female birds far outnumber the males, that the latter not only go through what may be termed "a gallantry show" on fine spring days, by throwing back their heads, blowing out their neck-pouches, trailing their wings, and spreading their tails fanwise, but also fight most furiously among themselves, and, lastly, that I have on more than one occasion 
actually seen one male perform the procreative operation upon several females in the course of a few minutes; it is therefore clear to my mind that when the male Bustard "pairs," it is from a lack of females, and not from the affectionate constancy which is supposed to govern and restrain the passion of many other species. About the second or third week of April the hen Bustards scratch a slight cavity in the ground, almost always amongst growing corn, occasionally collect a few dry straws or grasses therein, and commence to lay : the usual complement of eggs is three, often only two are laid, the most I ever heard of in one nest was five; they are not remarkably large for the size of the bird, and their ground-colour varies from a pale dull green to dark olive-colour, more or less blotched with splashes of a darker green-brown. As soon as the female birds begin to sit, the males, who have previously ceased to "keep company," unite in flocks and betake themselves to the most open flat ground that they can find, especially to the uncultivated parts of the great alluvial plains of the lower Guadalquivir, between Seville and San Lucar de Barrameda. Large portions of these plains are under cultivation, and the inale Bustards are often to be seen amongst the corn in which there are females on their nests; but during the greater part of the day in May the former seem to prefer the cattle-pastures, in which the vegetation at that time is occasionally very strong and rank, or the open undrained marshes, which in an average season are more or less under water from the end of October till the following spring, and in May barely afford sufficient covert to conceal a Lark; here these splendid birds may be observed in all their 
glory of perfect nuptial plumage, and conscious strength and beauty, stalking about with a stately and deliberate gait, the body always carried horizontally, and occasionally showing off, apparently from pure " pride of life," in the Turkey-cock fashion above described. Towards evening and in the early morning they go off to feed in some favourite

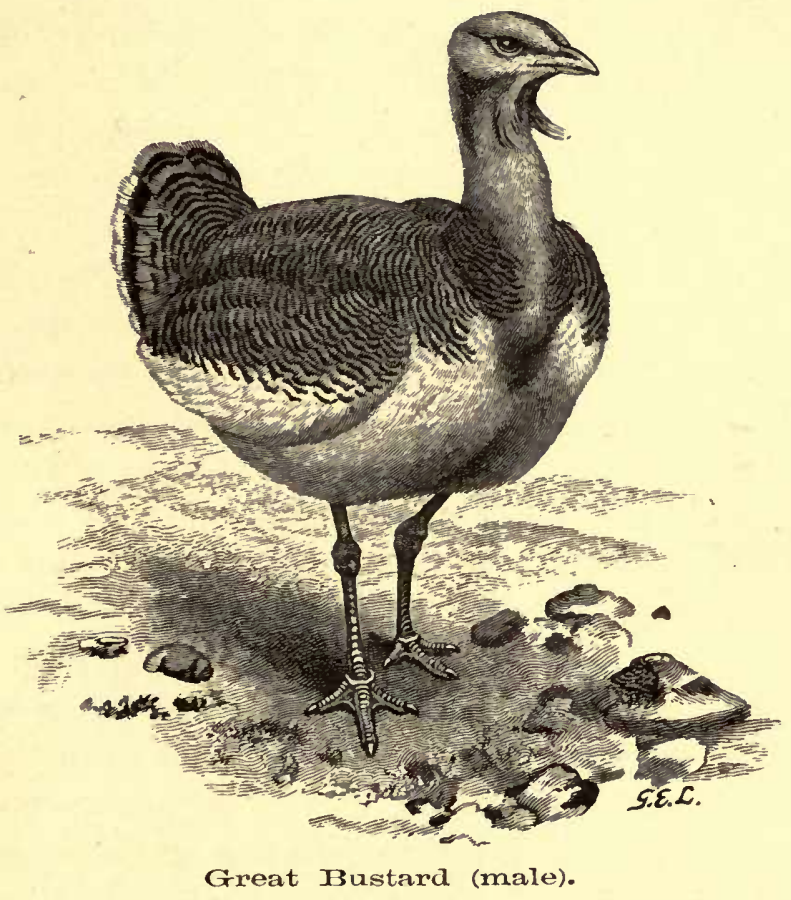

"querencia," a Spanish word difficult to translate briefly, but implying a haunt that supplies a want, generally a piece of land sown with chick-peas, clover, or vetches; but they seem always to return to the marshes for the night, and, I believe, spend the dark hours in the same formation as that of a covey of Grey Partridges, viz., squatting on the 
ground in a closely packed circle with their heads outwards.

I have never seen any of the Eagles or other birds of prey attack the Great Bustard; but Bonelli's Eagle, Pseudaëtus bonelli, occasionally does so, and on the downs they are open to the nocturnal onslaughts of foxes, wild cats, and other predatory beasts.

A great many Bustards are killed in Spain at night with the assistance of a horse, a bell, and a lantern: the gunner, having discovered a roostingspot, selects a dark night and advances by the side of his horse, with a confederate on the other side occasionally tinkling the bell and throwing a gleam forward from the lantern; as soon as the gunner perceives the grey heads of the birds he pours in his fire, and we have seen eight grand old male Bustards brought into Seville as the result of two shots delivered in this murderous fashion. The flesh of the old male Bustard is tough and coarse, but very good soup can be made from it, whilst the females and young birds are very excellent eating, but the Spaniards do not seem to care for them much as food, and their market price in Seville can hardly remunerate the professional shooters for their time and trouble. Some few gentlemen of the English colony at Jerez de la Frontera have bagged Bustards by stalking and shooting them with a rifle, and this is no doubt the really most artistic and sporting way by which to attack them, but the only method that I have employed is driving, or rather having the birds driven, and although there is of course but very little art required in bringing down a Bustard at a fair distance, a considerable amount of skill and know- 
ledge is requisite on the part of the drivers, and a large element of uncertainty and what we call chance, render this manner of shooting real sport in my estimation,- - the generally beautiful weather, the variety of birds to be observed, and the fact that many parts of the country are still virtually much as God made them, adding very greatly to the delights of a day among the Great Bustards in Andalucia. The peculiarly balmy but exhilarating air, which, come from whatever quarter of the compass it may, has blown for miles over wastes of rosemary, gum cistus, and thyme, or through pine-woods and orangegroves, possesses an indescribable charm, and renders existence in itself more enjoyable than in any other part of the world with which I am acquainted.

With these surroundings, I will beg my courteous reader to accompany myself and a friend, in imagination, in the first instance, from Seville by carriage to a certain wine-shop at some five miles' distance from that city, on the road to Badajoz, where we have appointed our drivers to meet us with a horse or two from the village of Algaba before mentioned; crossing the river by the bridge of Triana and threading the main street of that gipsy-haunted suburb, we leave the ruins of Italica to our left and the tall tower of Santi Ponce with its wheeling Kestrels to our right, and come in sight of the village and old Moorish watch-tower of Algaba, on the river-bank and about two miles off to our right front. Of birds we have observed Sparrows in abundance, several Crested Larks dusting themselves on the road or floating on in front of us with a flutelike whistle, a few Stone-Chats, and possibly Black Redstarts, perched about the spikes of the aloes which fringe the road here and there, Goldfinches 
and Serins wherever there are trees, a few Bee-eaters skimming over the cornfields, one or two Storks busily investigating any swampy spots, Swifts, Swallows, and Martins taking their pleasure and food all around, and very probably a Russet Chat flitting about a fallow from clod to clod and very conspicuous from the brilliant contrasts of his dress of white, sandy, and black. It is not improbable that we may see a Griffon Vulture or two sailing, on almost motionless wings, high in the air, and we have almost always noticed one or two of the scavenger Egyptian Vultures not far from Algaba, a village always pre-eminently in need of their services. Arrived at our destination, we find three men and two beasts, and here I must pause to do justice to the chief actor in the subsequent proceedings: imagine in your mind's eye a little man, in features very closely resembling Doctor Stanley, the late eminent Dean of Westminster, clad in a scanty and very flimsy jacket and blue cotton trousers, with the invariable red "faja" or sash about his loins, and the conventional Spanish black plush "calanies" or pork-pie hat, in the rim of which he carries his tobacco, cigarette-paper, and tinder; with not an ounce of flesh upon the wonderful muscles and sinews which underlie his sun-tanned skin; add to these details a pair of small and piercing dark eyes, with that peculiar puckering of the skin around them that comes from habitual scanning of the distant horizon under a bright sun, and is so remarkable amongst nomad Arabs and sea-farers, and you have before you the famous "Perico," or, to give him his proper designation, Señor Don Pedro Molina, the best driver of Bustards and one of the most typical Andalucian peasants of my acquaintance, warranted 
to drink any amount of the white country wine and to eat any amount of red sausage, or any other highly seasoned provend with which his temporary employer may supply him, but, full or famishing, equally ready to get over from thirty to forty miles of any sort of country daily under a hot sun, and come home singing if successful, and vociferously objurgatory if things have gone ill; he was always accompanied by his two brothers-in-law, larger and more stolid than himself, but with sufficient intelligence to carry out his directions, and a lad to ride the donkey that carried our provisions, ammunition, and any Bustards that we might kill. 'The country about our place of meeting consists for the most part of undulating corn-land, with occasional stretches of virgin down and grassy valleys. As soon as we are ready we start in a westerly direction, Perico ahead and his brothers-in-law to right and left of him, their usual pace an honest five miles an hour till they approach a ridge or sky-line, when they doff their head-gear and advance, cautiously stooping till they can command a view over the summit of the down; we watched them anxiously, and great was our delight when one or other of them dropped flat upon the ground for an instant, and the three came rushing back to us with the welcome announcement of "Hay pajaros!" "There are birds!" After a brief consultation as to the wind, Perico led off the guns to their posts, if possible generally in a dry watercourse, often in the middle of standing wheat, and now and then with no concealment but a patch of tall thistles or mallows to our front; in the latter case it was often necessary to lie flat or to kneel; but these positions of course we always avoided as much as possible, the right thing being the turfy 
buttress of a watercourse, with a light screen of foliage through which we could command the top of the ridge.

The Bustards will never fly against a strong wind for any great distance, and, in common with most birds of our acquaintance, very much object to come straight down the wind if it blows hard; so that Perico always did his best to place the guns so that the birds should come over us with the wind abeam of them. His directions to the shooters were always the same: "Keep as immovable as you can; as soon as you see the birds, select the biggest 'Barbon,' $i$. $e$. old bearded male, that seems to be coming for you, and aim at his beak." Having thus instructed and placed us, off he went, and posting the lad with the quadrupeds well out of sight, detached his lieutenants with orders to watch him, and when he approached the birds to show themselves on either flank. We gunners seldom were called upon for any long exercise of patience, though we were sometimes excited by the approach of some desirable bird, such as a Little Bustard, an Eagle, a Harrier, or a Roller; but as we were always posted as near as possible to our intended prey, a shot at anything else would have been fatal to our chances, and we contented ourselves with a look at any other birds, a pipe, and expectation. At last "here they come" over the ridge in front of us, generally only just clearing the top as they come in sight; but if we are in one of the watercourses just mentioned we are of course in a valley, and by the time the birds are within range they will probably be from twenty to fifty yards up in the air. No one who has not tried it would believe how easily these great birds are brought down; I never used any larger shot than No. 4, and often 
No. 6 , and with that weight of metal never failed to secure, and generally to kill "stone-dead," any Bustard that passed within reasonable distance, whilst many a Wild Goose when shot at at the same ranges has merely shaken himself, cackled, and gone on unhurt. It seems still harder to believe that I have seen one or two famous pigeon-shots, besides many other fair performers with the fowling-piece, entirely miss Great Bustards at easy distances. The late Captain of my yacht, for instance, who, though very uncertain as a shooter, could often knock down a Wild Duck and sometimes a Snipe, and certainly had more fair chances at Bustards in Spain than any other of our variously composed parties, only fairly killed one; but he was by no means the only one of us who was, I presume, fairly puzzled by these birds coming straight at or over him.

In the expeditions just described we considered three or four Bustards as a fair bag-not by any means on account of their scarcity, but because the flocks seldom settled again within three or four miles of their first rise, and not very often gave a chance to more than one or two of our party in any one drive; below Seville, however, they behaved very differently, as they are of course much less liable to disturbance in the great marshes and pastures than when amongst the corn-growing downs. The greater part of our Bustard-hunting below Seville was carried out from my yacht, at anchor in the river, and there, with a steam-launch and two or three mounted drivers, we saved a great deal of time and occasionally met with very fair success, besides picking up a few Ducks of various species, an occasional Grey-lag Goose, a Crane, Sand-Grouse, Snipes, Avocets, Godwits, Greenshanks, and other Waders. These great plains, 
indeed, form a perfect paradise for a vast number of species of the fowls of the air, the number and variety of raptorial birds, from the huge Griffon and Black Vultures down to the little Merlin and Sparrow-Hawk, is perfectly astonishing, and in the lower portion of the valley of the Guadalquivir it is by no means an uncommon occurrence to see thousands of Flamingoes fringing the horizon in long lines, or at a great distance giving the impression of a dense rose-coloured cloud as they rise and shift their quarters.

The Great Bustard is exceedingly wary and sharpsighted, and although there are many traditions of their having been killed in this country by the aid of trained stalking-horses, the Spaniards whom I questioned told me that to get a shot in that manner by daylight was quite an exceptional occurrence, though their horses are perhaps the most docile in Europe, and by their aid great numbers of wildfowl of various kinds, and Sand-Grouse, quite the most wary of birds, are annually killed. It is remarkable that although the Great Bustard often visits the plains of Epirus and Albania, and is reported as breeding in the Morea, I only saw one during nearly two years' constant rides and shooting expeditions in those provinces, when my headquarters were at Corfu; but in the winter of 1858 a party of four from that island were more fortunate, and killed over fifty Bustards in about a week by waiting for them at morning and evening on their passage to and from their feedingground near the Gulf of Arta and not very far from Prevesa.

The tales of Bustards being habitually coursed with greyhounds are myths, and probably originated from the fact of an occasional "chopping" of one by 
a dog who came suddenly down wind upon it in a gale, or from captures of moulting or young birds before they could fly; for although the Bustards can run at great speed, and always do so for a few yards before taking wing, their flight is very powerful and, for so heavy a bird, rapid and well sustained. It is true that the old males, after two or three long flights in warm weather, often fly within a yard or two of the ground with their beaks open and panting audibly; but even on these occasions they will flap on for a mile or two, and are certainly more difficult to tire out than the Red-legged Partridge. The Spaniards assured us that when mortally wounded, but not instantly killed, the Bustards invariably void their excrement on receiving the shot, and my own experience fully confirms the truth of this statement.

I have very recently been furnished, by the kindness of a friend, with some very interesting details concerning the Great Bustard in Yorkshire in the early part of this century ; they are too bulky to transcribe at length, especially after having been induced to wander so far from Northamptonshire as I have been beguiled to do by delightful reminiscences, but the pith of these Yorkshire memoranda is to the effect that, in the spring or early summer of 1828, a Bustard was sitting on her eggs in a field on the high wolds, on land at that time in the possession of the Duke of Devonshire. 'The writer of these memoranda was informed of this fact by the tenant of the farm upon which the nest was situated, but never heard of the result. The second important fact, communicated in MS. to the writer by a grandson of the perpetrator, is the capture of no less than eleven Great Bustards as the result of a single discharge of a heavy shoulder-gun from behind a 
trained horse, on the high wolds near Burrow, between Sledmere and Langtoft, in (presumably) the month of March, 1808. The shooter was a gamekeeper of the name of Agars, who was at that time in the employ of Mr. W. Thomas St. Quintin, of Scampston Hall, near Malton. The third story, which has in all probability been recorded before, relates to the shooting of a Bustard by a tailor near York, in 1865; this specimen was stuffed and mounted by Graham, the well-known York birdstuffer, and is now in the museum of that city.

The Great Bustard is easily reared and thrives well in captivity, sometimes becoming very tame, but requires a good range of ground and protection from cold winds and especially from damp. All the birds of this species that I have kept alive at Lilford had a frantic terror of dogs, and lost all self-control at the sight of one. Notwithstanding much learned writing and discussion on the subject of the singular gular pouch, or bladder, which is fully developed only in the old males of this species during the breedingseason, and it would seem not invariably even in such instances, I am not aware that any conclusive opinion as to its use has been published; my own conviction on the subject is, that it is a reservoir for air, which is pumped up into the mouth when the bird is on the wing, and thence drawn into the lungs, by which means the labour of respiration through the nostrils is economized; but this is of course only a surmise, probably quite an unscientific one, and I very much wish that I could hear of a better explanation of the purposes of this very curious appendage. The only note that I have ever heard from a Great Bustard is a sort of guttural cough, when suddenly irritated or surprised; but I have my 
suspicions that these birds utter a ventriloqual sound in the breeding-season.

Since the above article was first published, I have frequently heard my young Bustards at Lilford utter a curious plaintive moan, especially when separated by chance or design from their companions.

\section{LITTLE BUSTARD.}

\section{Otis tetrax.}

Captain J. Borlase Tibbits, of Barton Seagrave, was good enough to inform me by letter that a young female of this species was shot by his brother, the late Rev. G. E. Maunsell, in a turnip-field on the lordship of Rothwell, on November 20, 1858, that the bird was stuffed and mounted by Ward, and at the time. of Captain 'Tibbits writing to me was at Thorpe Malsor. The Little Bustard is an irregular and accidental visitor to our Islands, generally occurring in the late autumn, winter, or early spring, and I am not aware of any record of its nest ever having been found in this country. In most of its habits, haunts, and food, as well as in shape and general coloration, this bird resembles the Great Bustard; but it is a more southern species, breeding locally in Portugal, Spain, Sardinia, France, Italy, Sicily, Turkey in Europe, S. Russia, and Greece. I believe that it is only an accidental visitor to Germany proper, but breeds in some of the eastern provinces of the Austrian Empire, Hungary, and on both sides of the Lower Danube. It is also reported as abundant in parts of Asia Minor and Western Asia; it is also found to our knowledge in Morocco, Algeria, and Tunis, In its most northerly breeding-haunts it is a 
spring visitor, arriving in April, and moving southwards at the approach of winter; but in Spain, Sardinia, Sicily, and Tunis it may be found in suitable localities throughout the year.

The Little Bustard, though it loves the open, does not, in our experience, frequent the absolutely flat country of Spain in the breeding-season to the same extent as the larger species, nor is it, at that time of year, to be met with so frequently in the corn-lands. Undulating pastures, where water is near, are, in Spain, the favourite spots for this bird in summer. On one occasion in the month of June, whilst travelling by railroad from Cordova to Madrid, I must have seen quite a hundred Little Bustards rise, singly or in couples, at the approach of our train, from grass-lands such as those that I have just mentioned.

The males, although they go through much the same sort of "show" as the Great Bustard, and appear to be at the commencement of the season nearly as promiscuous in their amours, eventually select a mate and remain in her close vicinity during the time of incubation. The nests of this species are generally placed in thick grass, and consist of a scratching in the ground, with generally more bedding of dried straws and stems than is found in those of the Great Bustard. The eggs are usually of a very dark olive-green, clouded with still darker stains and blotches. I have seen specimens entirely uniform in colour, without markings of any sort; their number is generally three or four, often only two.

The Spaniards say that the "Sison," as they call this species, generally produces two broods; I am unable to verify or deny this statement from personal observation, but I know that in September old and 
young collect into large flocks, are exceedingly difficult to approach on foot, and frequent bare downs, stubble, and fallow lands. Many of these birds are killed at night by the same means as those above described concerning the Greater Bustard, and a good many are also shot in the great heats of August and September, when they will now and then lie close amongst the palmetto scrub and other bushes that clothe many of the wastes of Southern Spain. I never heard of much success in "driving" these birds, though we killed a few in Spain and in Tunis by this means; they generally rise to a great height at once, and fly for miles if really alarmed. Most of the few Little Bustards that I have shot were obtained in New Castile, in some waste country to the south of Aranjuez, in the spring of 1865. At that season the male bird betrays his presence not only by a very singular call, which I can only approximate to by the abrupt pronunciation of " prrut," but also by occasional leaps of a foot. or two into the air, when the black and grey of the nuptial plumage of his neck and the white of the lower parts render these sudden saltatory performances very conspicuous. By advancing towards the spot on horse- or mule-back, and occasionally on foot, we could now and then get a long shot at the male, who sprung into the air with a loud clatter and whirr, whilst the female, who was always near her mate, would generally rise after him within easy range.

On wing the Little Bustard is very fast, and seen from above or sideways has much the appearance of a Pied Greyhen, but from below reminds me of a gigantic Ptarmigan in winter dress. The action of the wings produces a strong whistling sound, from which the bird derives the Spanish name above mentioned. 
I have kept several Iittle Bustards at various times in the aviaries at Lilford. They become very tame, and are very peaceable with other birds, but cannot support any continuance of exposure to wet or severe cold. The flesh of this species is generally much esteemed, and is, indeed, remarkably good ; in Spain it is often served up in the hotels under the name of "Faisan," $i$.e. Pheasant. On inquiring the name of two birds of this species in the Biarritz market, I was told that they were Poules d'Afrique, but the generally recognized name in France is Canepetière, and amongst the French of Algeria and Tunis, Poule de Carthage. In the Danubian Provinces many Little Bustards are killed by driving round them in a light cart, gradually diminishing the circle, by which means the vehicle always appears to be going away from the birds. We have found this system answer well, not only on wheels, but also on horseback and on foot, with many naturally wary birds. Two other species of Bustard are recorded as having occurred in Europe, and one of them, Macqueen's Bustard, Otis macqueeni, twice in this country. This bird appears to be resident in the deserts of Western Asia, and visits the plains of Sind and the Punjab in the cold weather. The other species alluded to is the African Houbara, or Ruffed Bustard, Otis undulata, which is not uncommon in the great plains of Southern Algeria, Tunis, and Tripoli, and has occurred in Andalucia and Malta. The males of both these latter species are distinguished by a long ruff. 


